UNiVERSIDAD de SALAMANCA

Departamento de Lengua Española

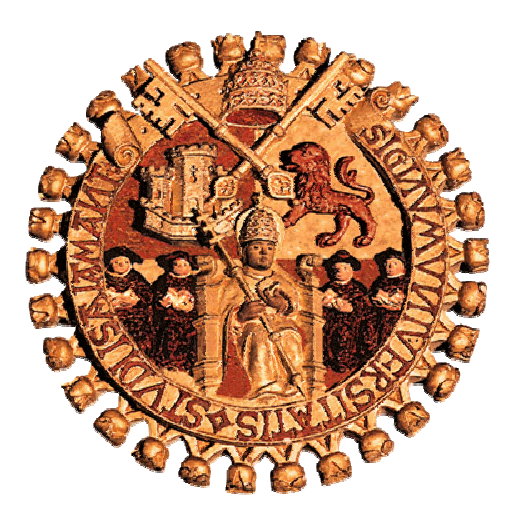

\title{
EL DISCURSO AJENO EN LOS TITULARES PERIODÍSTICOS
}

\author{
Tesis doctoral realizada por: \\ JUAN GABRIEL NADAL PALAZÓN
}

Dirigida por:

DRA. D. ${ }^{a}$ ELIZABETH LUNA TRAILL

$\mathrm{y}$

DR. D. FRANCISCO JOSÉ ZAMORA SALAMANCA 


\section{ÍNDICE}

0. Introducción..............................................................................................

0.1. El discurso ajeno....................................................................... 10

0.2. Metodología y características del corpus................................................. 16

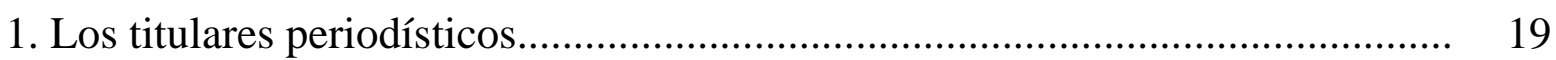

1.1. Aclaración terminológica........................................................................ 21

1.2. Funciones de los titulares....................................... 22

1.3. Condicionantes de los titulares.................................. 25

1.4. ¿Quién redacta los titulares?........................................................... $\quad 30$

1.5. Orígenes de los titulares modernos................................. 34

1.6. La configuración lingüística de los titulares........................ 36

1.6.1. Rasgos constantes................................................................. 38

1.6.1.1. Bimembración expresiva................................................ 38

1.6.1.1.1. Bimembración del tipo 1:

marco de referencia............................ 39

1.6.1.1.2. Bimembración del tipo 2:

discurso directo............................. 40

1.6.1.1.3. Bimembración del tipo 3: 41

1.6.1.2. Elipsis................................................................... 42

1.6.1.2.1. Elipsis del tipo 1:
verbos de habla................................................. 43

1.6.1.2.2. Elipsis del tipo 2:

determinantes.............................. 44

1.6.1.2.3. Elipsis del tipo 3:
nexos............................................ 47

1.6.1.2.4. Elipsis del tipo 4:
Sustantivos.......................................... 50

1.6.1.3. Estructuras nominales.................................................. 51

1.6.1.4. Presente histórico...................................... 52

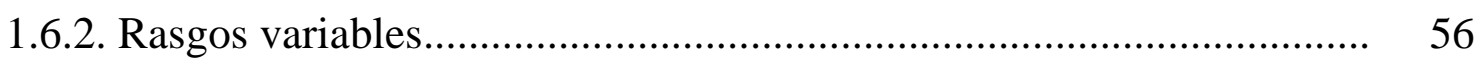

1.6.2.1. Tercera persona impersonal........................................... 56

1.6.2.2. Verbo inicial..................................... 58

1.6.2.3. Potencial citativo...................................... 60

1.6.2.4. Criptónimos.......................................... 61

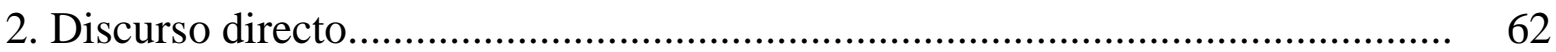

2.1. Discurso directo marcado................................................................. $\quad 70$

2.1.1. Verbo subordinante............................................................... 74

2.1.1.1. Segmento 1 con verbo subordinante expreso.................... 80 
2.1.1.2. Segmento 1 con verbo subordinante elidido.................... 83

2.1.2. Marcas ortográficas........................................................... 87

2.1.3. Doble marca..................................................................... 91

2.2. Discurso directo no marcado........................................................... 96

2.3. Consideraciones finales............................................................ 105

3. Discurso indirecto....................................................................... 119

3.1. Discurso indirecto marcado......................................................... 128

3.1.1. Verbo y conjunción subordinantes........................................ 130

3.1.2. Verbo expreso y conjunción elidida..................................... 134

3.1.3. Conjunción expresa y verbo elidido........................................ 137

3.1.4. Con la preposición para ................................................. 141

3.1.5. Condicional con valor de potencial citativo.................. 144

3.2. Discurso indirecto no marcado........................................................ 149

3.2.1. Declarante representado en el texto..................................... 158

3.2.1.1. Oraciones............................................................. 159

3.2.1.1.1. Alusión a Loc 2 en caso agentivo.................... 160

3.2.1.1.2. Alusión a Loc 2 en caso dativo........................ 161

3.2.1.1.3. Alusión a Loc 2 en caso locativo...................... 162

3.2.1.2. Frases................................................................... 163

3.2.2. Declarante no representado en el texto, pero sí en el contexto.... 164

3.2.2.1. Oraciones............................................................... 165

3.2.2.1.1. Oraciones con sujeto léxico.......................... 167

3.2.2.1.1.1. Sujeto humano............................... 167

3.2.2.1.1.2. Sujeto no humano........................... 168

3.2.2.1.2. Oraciones sin sujeto léxico............................ 173

3.2.2.1.2.1. Sujeto gramatical en la flexión

del verbo.......................................... 174

3.2.2.1.2.2. Haber impersonal.............................. 178

3.2.2.2. Frases................................................................. 179

3.2.3. Declarante no representado ni en el texto ni en el contexto........ 180

3.2.2.1. Oraciones............................................................ 181

3.2.3.2. Frases............................................................... 182

3.3. Consideraciones finales............................................................ 182

4. Discurso narrado......................................................................... 201

4.1. Oraciones simples....................................................................... 212

4.1.1. Verbo transitivo................................................................ 214

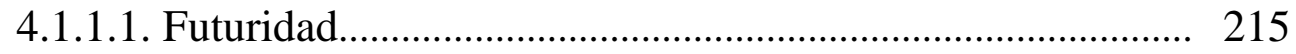

4.1.1.2. No-futuridad............................................................ 216

4.1.2. Verbo prepositivo............................................................. 220

4.1.2.1. Futuridad............................................................... 221

4.1.2.2. No-futuridad.......................................................... 222

4.1.3. Verbo intransitivo............................................................. 224

4.2. Oraciones con infinitivo objetivo............................................. 225

4.2.1. Verbo subordinante transitivo........................................... 230 
4.2.1.1. Concordancia de sujetos......................................... 231

4.2.1.2. Discordancia de sujetos................................................. 232

4.2.2. Verbo subordinante prepositivo............................................ 233

4.2.2.1. Concordancia de sujetos............................................ 234

4.2.2.2. Discordancia de sujetos......................................... 234

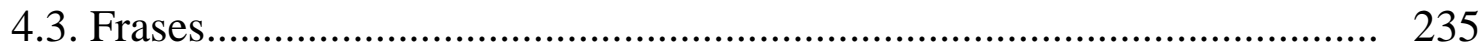

4.4. Consideraciones finales........................................................... 236

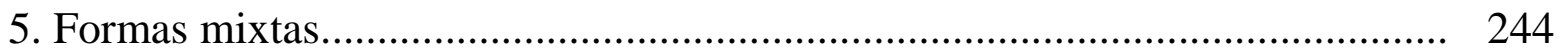

5.1. Hibridación local.................................................................... 249

5.1.1. Estructura receptora en discurso indirecto marcado................. 252

5.1.2. Estructura receptora en discurso indirecto no marcado.............. 255

5.1.3. Estructura receptora en discurso narrado............................. 256

5.2. Hibridación global.................................................................. 257

5.2.1. Discursos narrado e indirecto marcado................................. 258

5.2.2. Discursos narrado e indirecto no marcado................................ 259

5.2.3. Discursos narrado y directo marcado..................................... 259

5.2.4. Discursos directo marcado e indirecto marcado....................... 260

5.2.5. Discursos directo marcado e indirecto no marcado................... 260

5.3. Consideraciones finales............................................................ 261

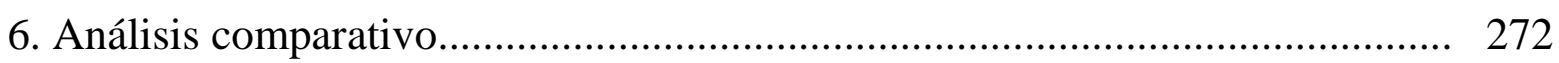

6.1. Aspectos cuantitativos............................................................... 272

6.1.1. Discurso directo.............................................................. 279

6.1.2. Discurso indirecto............................................................ 288

6.1.3. Discurso narrado............................................................. 294

6.1.4. Formas mixtas........................................... 296

6.2. Aspectos cualitativos.................................................................. 299

6.2.1. Doble escala.................................................................. 300

6.2.2. Aligeramiento y reiteración de marcas................................... 303

6.2.3. Orientación argumentativa................................................ 305

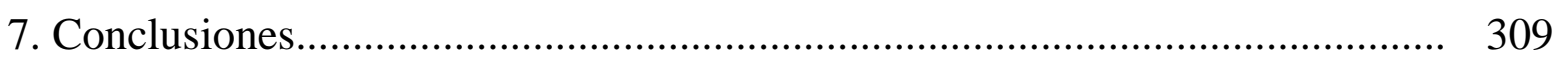

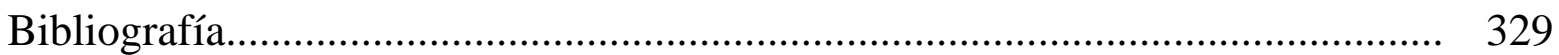

Apéndice 1: identificación de declarantes.................................................. 351

Apéndice 2: significado de abreviaturas empleadas en los titulares citados...... 354

Abreviaturas empleadas en las referencias................................................. 357 


\section{INTRODUCCIÓN}

Un asunto fundamental en los estudios del lenguaje es, sin duda, el procesamiento del habla ajena en la propia. Hasta tal punto es así que, desde hace años, algunos autores han venido planteando la posibilidad de que se trate de la esencia misma de la lengua. ${ }^{1}$ También se ha dicho que el generar imágenes de otros discursos es una capacidad del discurso en todas las lenguas del mundo, ${ }^{2}$ e incluso que constituye un rasgo general del comportamiento social del ser humano en cualquier cultura. ${ }^{3}$

Muy variados son los mecanismos de que dispone el hablante para procesar el discurso ajeno en el propio. Algunos producen enunciados más miméticos que otros. Algunos comportan la atribución del contenido de las palabras ajenas y otros no. Algunos ni siquiera exigen la representación del enunciado ajeno. Algunos suponen una adhesión del locutor con respecto al punto de vista expresado por el hablante que generó el enunciado original, y otros, un distanciamiento. Algunos destacan las palabras ajenas y otros las ocultan, disimulan o marginan. Algunos, en fin, presentan características híbridas.

Esta investigación pretende caracterizar y describir tales mecanismos a partir de un corpus de titulares periodísticos de diez países del mundo hispánico. Los encabezados son textos producidos en situaciones enunciativas que llevan al límite la tensión entre economía e informatividad. Esto, aunado al hecho de que más del $60 \%$ de las noticias se origina en declaraciones, hace de este un registro linguístico ideal para estudiar esos procedimientos. Además, como

\footnotetext{
${ }^{1}$ Por ejemplo, Bajtín (1935) 1986 y (1963) 1986, Voloshinov (1929) 1992.

${ }^{2}$ Cf. Jakobson (1936-1963) 1981: 308-309, Li 1986: 39-40, Collins 2001: 1, Sakita 2002: 2, Coulmas 1986: 2, entre otros.

${ }^{3}$ Haberland 1986: 219.
} 
veremos, el lenguaje de los titulares ha desarrollado estructuras propias, difícilmente empleadas en otras situaciones de habla.

En los capítulos siguientes, propongo un modelo de análisis del discurso ajeno, definido aquí como todo discurso o segmento discursivo que describe un acto discursivo ajeno. Aunque erigido sobre una descripción de titulares periodísticos, el esquema modélico general podría hacerse extensivo a otros usos discursivos de la lengua española.

Este trabajo responde, pues, a un primer objetivo de clasificación general de los mecanismos del discurso ajeno, dado que las clasificaciones existentes no resisten, como veremos, la prueba empírica que plantea la realidad del habla. Más adelante quedará patente la necesidad de categorizaciones modernas que tomen en cuenta factores tradicionalmente olvidados, como la norepresentación discursiva y el contexto lingüístico y extralingüístico.

Un segundo objetivo es describir y explicar los procedimientos específicos de procesamiento del habla ajena identificables en los encabezados de la prensa en lengua española, e identificar tendencias generales y comportamientos específicos de los diarios de los países considerados. Como veremos más adelante, los titulares son una manifestación importante de la lengua, que guía la interpretación de la realidad noticiosa y, por ende, la construcción del presente social. La codificación lingüística de los titulares descubre rasgos velados de la posición ideológica compartida por el locutor y la organización informativa. Independientemente de la naturaleza discursiva del problema, que discutiremos después, el estudio de ello exige un tratamiento epistemológico orientado a la interdisciplina y, como es obvio, un análisis que integre varios niveles de descripción lingüística.

El análisis combina, asimismo, métodos cuantitativos y cualitativos. La descripción estadística, referida básicamente a la caracterización general del 
discurso ajeno, tiene como principal finalidad determinar la importancia relativa de las distintas modalidades discursivas, así como identificar tendencias generales del discurso de los titulares y comportamientos específicos de los diarios considerados. El análisis cualitativo, en cambio, no pretende sino ilustrar parte de la inmensa riqueza de efectos de sentido que comportan las distintas variedades del discurso ajeno en los encabezados periodísticos.

Para esto último acudo, sobre todo, a la Teoría de la Argumentación en la Lengua, en varias de las etapas desarrolladas por Ducrot, así como a algunas aportaciones derivadas de esta. El análisis encontrará sustento, además, en otros autores, como Van Dijk, Fowler, Fairclough y Hodge y Kress. Como es natural, el asunto será abordado desde las varias perspectivas del análisis polifónico del discurso. ${ }^{4}$ Este análisis, que carece de toda pretensión de exhaustividad, se localiza, básicamente, en las consideraciones finales de los capítulos sobre las distintas modalidades del discurso ajeno.

La descripción y caracterización general se ha limitado, en la medida de lo posible, a los aspectos más formales de la estructura lingüística; no obstante, la naturaleza discursiva del objeto de estudio hace obligatorio considerar factores semánticos y pragmáticos. Se torna imprescindible, pues, un tratamiento epistemológico ad hoc que integre aportaciones pertinentes de métodos y teorías diversos, sobre todo si se considera que el asunto del discurso ajeno ya ha sido abordado desde perspectivas muy variadas.

Es preciso aclarar que, aunque muy abundante, la bibliografía se antoja insuficiente y, en algunos casos, francamente caduca. Solo en fechas recientes el discurso ajeno ha recibido la atención de lingüistas, y ya no solo de teóricos o críticos de la literatura. Si bien las aportaciones de la teoría literaria han sido

\footnotetext{
${ }^{4}$ Bajtín (1935) 1986 y (1963) 1986, Ducrot (1984) 1986, Nølke Fløttum y Norén 2004; cf. Puig 2004.
} 
fecundas, es obvio que el asunto trasciende los límites de este uso discursivo. La mayoría de los trabajos con orientación linguiística, sin embargo, suelen reducir el problema a fenómenos sintácticos de alcance estrictamente oracional, como ocurre en casi todas las gramáticas españolas que no ignoran el asunto. El carácter heterogéneo, dinámico y complejo del discurso ajeno plantea ciertas dificultades, no resueltas en la bibliografía especializada, que será necesario atender para lograr una adecuada clasificación del material recogido.

En los siguientes apartados de esta introducción, explicaré lo que se entenderá aquí por discurso ajeno y justificaré la definición proporcionada; demostraré también que el asunto aquí estudiado es de naturaleza discursiva. Expondré, asimismo, el procedimiento seguido para recoger los materiales, así como la composición y las dimensiones del corpus.

El primer capítulo contiene, a manera de marco de referencia, una revisión general de algunos aspectos relativos a los titulares periodísticos. Allí especificaré lo que aquí se entenderá por titular periodístico y explicaré la necesidad de su estudio. Referiré también sus funciones más habituales y los factores principales de los que depende su formulación. Abordaré asimismo el no siempre claro asunto de su autoría y presentaré un somero recuento histórico de los orígenes de los encabezados modernos. Finalmente propondré, sin ánimo de exhaustividad, un breve inventario de los rasgos formales de codificación lingüística más característicos de este tipo de texto.

El segundo capítulo se refiere al discurso directo, variedad del discurso ajeno caracterizada por la retención del sistema deíctico del locutor citado y asociada convencionalmente con el polo semántico de una supuesta retransmisión literal. El capítulo observa sus dos grandes variedades: marcado y no marcado. Las formas marcadas contienen elementos lingüísticos que señalan explícitamente este tipo de retransmisión; los titulares periodísticos 
presentan, como marcas, verbos de habla subordinantes e índices gráficos, o una combinación de ambos.

En el tercer capítulo, abordaremos la variedad del discurso ajeno más abundante en los encabezados: el discurso indirecto. Esta modalidad presenta siempre una reformulación analítica de las palabras ajenas, con transposiciones deícticas de persona cuando en el texto se alude explícitamente al locutor o al alocutario de la enunciación propia o ajena. Veremos que las formas no marcadas son mucho más abundantes que las marcadas. Las marcas suelen ser oraciones subordinantes con verbo expreso o elíptico, acompañadas o no por conjunción; registro también, no obstante, secuencias que incorporan la preposición para seguida por un sintagma nominal en adjuntos periféricos y otras que contienen usos de condicional con valor de potencial citativo. Las formas no marcadas serán descritas según se mencione o no el declarante - la fuente informativa - en el titular o en el texto que este rotula.

El capítulo cuarto comprende la caracterización, descripción y explicación de la modalidad del discurso ajeno menos estudiada en las investigaciones lingüísticas: el discurso narrado. En esta variedad, el locutor refiere el acto de habla ajeno como cualquier otro tipo de acción, es decir, sin emplear estructuras especializadas en la representación discursiva, tales como los discursos directo e indirecto marcados. Los titulares serán descritos según su estructura sintáctica general: frases, oraciones simples y oraciones con infinitivo objetivo. Propondré una clasificación de los encabezados a partir de significados denotativos comunes.

El capítulo quinto está dedicado a las formas mixtas, las menos frecuentes en el corpus. Estas son fórmulas discursivas que presentan características de distintas variedades puras del discurso ajeno (esto es, discursos directo, indirecto y narrado). Hablaré de hibridación local o global dependiendo de si 
hay o no relación hipotáctica entre dos segmentos identificables, por separado, como ejemplos de distintas variedades puras del discurso ajeno.

Antes de una breve recapitulación general a manera de conclusiones, el capítulo sexto contiene un análisis comparativo de las distintas variedades del discurso ajeno identificadas en el corpus. Desde la perspectiva cuantitativa, quedarán identificados una tendencia general y dos comportamientos específicos que describen la distribución de las formas del discurso ajeno en los diarios considerados e incluso revelan actitudes que, hasta cierto punto, condicionan el grado de incidencia de las modalidades estudiadas. Desde la perspectiva cualitativa, describiré de manera general algunas circunstancias y propiedades de índole semántico-pragmático-discursiva que también motivan, parcialmente, el uso de las distintas variedades del discurso ajeno en los titulares periodísticos, bien entendido que la configuración lingüística de los titulares es el resultado de un complejo proceso multicausal que no debe ser simplificado abusivamente. Quedará patente que existe una doble escala en los procesos linguiísticos del discurso ajeno, la cual vincula los dominios de los ejes apropiativo-atributivo y mimético-diegético, factores estos distintivos de las varias modalidades discursivas estudiadas. Advertiré, asimismo, algunas consideraciones importantes que se desprenden de lo anterior; entre ellas, que el uso de las variedades del discurso ajeno responde a estrategias persuasivas, y enumeraré algunos de los mecanismos por medio de los cuales los encabezados ofrecen una orientación argumentativa.

Para facilitar al lector la comprensión de los ejemplos, el "Apéndice 1" contiene información identificadora de las fuentes informativas de algunos titulares citados a manera de ejemplos, cuya vigencia se restringe al momento de la enunciación periodística. Se ofrece, en el “Apéndice 2”, el significado de las abreviaturas —básicamente siglas y acrónimos - que aparecen en los titulares reproducidos en el análisis. 
Solo resta advertir que, en todos los titulares reproducidos en este trabajo he respetado fielmente la ortografía de los originales. Los he transcrito en letras de espesor regular, bien entendido que los titulares suelen imprimirse en negrillas, cuyo uso se reserva aquí para destacar algunas unidades a las que se alude en el análisis. (siempre con advertencia explícita). Entre corchetes añado la referencia del texto: coloco primero el nombre del periódico, abreviado y en versalitas; después de un espacio, la fecha, y, por último, tras dos puntos, la página. Al final de este trabajo se encuentra la correspondiente lista de abreviaturas.

\subsection{El discurso ajeno}

Diversas son las denominaciones bajo las cuales se han agrupado los diferentes procedimientos de que disponen las lenguas para procesar el habla ajena: discurso referido, ${ }^{5}$ discurso reportado, ${ }^{6}$ discurso ajeno, ${ }^{7}$ discurso reproducido, ${ }^{8}$ discurso representado, ${ }^{9}$ cita. ${ }^{10}$ Como bien afirman Janssen y Van der Wurff ${ }^{11}$, en términos generales no existe consenso en la terminología empleada en los estudios especializados. Si bien hay autores que proponen ciertas diferencias entre algunos de estos términos, ${ }^{12}$ lo más frecuente es que se empleen de manera completamente indistinta.

Resulta necesario, en consecuencia, detenerse para definir los términos que aquí serán empleados. Entiendo por discurso ajeno no solo las palabras generadas por otro locutor, sino también, por extensión, todo discurso o segmento discursivo que trasluzca, de manera explícita o implícita, la alusión

\footnotetext{
${ }^{5}$ Rivarola y Reisz de Rivarola 1984, Fonte 1996c.

${ }^{6}$ Coulmas 1986, 1994; Maingueneau 1981, Authier y Meunier 1977.

${ }^{7}$ Voloshinov (1929) 1992, Beltrán Almería 1992.

${ }^{8}$ Maldonado 1991 y 1999, Fernández Lagunilla y Pendones 1996.

${ }^{9}$ Fairclough 1988, Nølke, Fløttum y Norén 2004.

${ }^{10}$ Partee 1973, Reyes 1993, 1994a.

${ }^{11}$ Janssen y Van der Wurff 1996: 3.

${ }^{12}$ Por ejemplo, Reyes (1984) y Maldonado (1991).
} 
o presencia de un enunciado ajeno en el propio. ${ }^{13}$ Dicho de otro modo, se trata del conjunto de procedimientos de descripción explícita o implícita de un acto discursivo ajeno en el propio. Siguiendo a Voloshinov, llamaré primaria a la enunciación propia, y secundaria, a la ajena; en el discurso ajeno, dice este autor en su trabajo seminal, la enunciación primaria trasluce siempre una enunciación secundaria. Para abreviar, llamaré Loc 1 al locutor de la enunciación primaria, y $\operatorname{Loc} 2$, al de la secundaria. ${ }^{14}$

De acuerdo con Voloshinov, discurso ajeno no solo es "discurso en el discurso, enunciado dentro de otro enunciado": también es "discurso sobre otro discurso, enunciado acerca de otro enunciado". ${ }^{15}$ En otras palabras, la noción de discurso ajeno abarca los términos discurso referido y discurso reproducido, que se oponen gracias a la condición de representatividad: ${ }^{16}$ para hablar de discurso reproducido, es necesario que, entre la cadena verbal resultante de la enunciación primaria y el producto lingüístico de la enunciación secundaria, exista una cierta relación de semejanza. ${ }^{17}$

El discurso referido, por el contrario, no implica representatividad: "Tan sólo describe una acción realizada verbalmente". ${ }^{18}$ Esto es, el sujeto de la enunciación primaria - Loc 1- refiere la existencia de una enunciación ajena sin necesidad de evocar icónicamente el enunciado original. ${ }^{19}$ El

\footnotetext{
${ }^{13} \mathrm{Si}$ bien es cierto que, en sentido estricto, el discurso ajeno es aquel que genera cualquier sujeto de una enunciación ajena, en este trabajo he reservado el término para referirme a los mecanismos lingüísticos por los que, en un enunciado, se alude o representa la enunciación o el enunciado que supuestamente ha producido otra persona.

${ }^{14}$ Me baso en la nomenclatura propuesta por Ducrot ([1984] 1986: 198): "Entiendo por locutor a un ser que, en el sentido mismo del enunciado, es presentado como su responsable, es decir como alguien a quien se debe imputar la responsabilidad de ese enunciado. A él remiten el pronombre yo y las otras marcas de primera persona." En mis materiales, el locutor primario coincide siempre con la entidad que este autor denomina productor empírico, es decir, el ser de la realidad factual que produce el enunciado: en todos los casos de mi corpus se trata del periodista responsable de la redacción del titular.

${ }^{15}$ Voloshinov [1929] 1992: 155. Cursivas en el original.

${ }^{16}$ Maldonado 1991: 20.

${ }^{17}$ Reyes 1984, 1993 y 1994a, Maldonado 1991 y 1999.

${ }^{18}$ Maldonado 1991: 20 y 1999: 3556.

${ }^{19}$ Parmentier 1993, Waugh 1995.
} 
discurso referido no es sino la simple mención de un acto lingüístico ajeno, sin pretensiones de semejanza necesarias. Como bien apunta Maldonado, "reproducir supone siempre referir, pero no al contrario". ${ }^{20}$

La mayoría de los estudiosos del discurso ajeno ha centrado su atención en lo que hemos llamado discurso reproducido y, por consiguiente, ha dejado de lado las variedades de discurso referido que no suponen una reproducción del enunciado secundario. ${ }^{21}$ Los autores que sí las toman en cuenta no suelen dedicarles, sin embargo, más de unas cuantas líneas. ${ }^{22}$

Además, como veremos, no todos los fenómenos del discurso ajeno son oracionales: para poder describirlos es necesario conocer el texto íntegro y su contexto, entendido este último en un sentido amplio. El discurso ajeno es, en gran parte, un asunto de índole discursiva, no necesariamente oracional. ${ }^{23}$ Muchos especialistas, empero, han restringido sus estudios sobre discurso ajeno a descripciones de estructuras morfosintácticas, ${ }^{24}$ tal como sucede en casi todas las gramáticas españolas que no ignoran el tema. ${ }^{25}$

En síntesis, la noción de discurso ajeno abarca todos los discursos o segmentos discursivos que traslucen alusión o presencia de un enunciado ajeno en el propio. Los indicios de ese traslucimiento pueden hallarse ya en el nivel textual, ya en el contextual, ya en el suprasegmental. ${ }^{26}$ Dado que se trata

\footnotetext{
${ }^{20}$ Maldonado 1991: 20.

${ }^{21}$ Entre otros, Jespersen (1924) 1968, RAE (1931) 1962 y 1973, Gili Gaya 1967, Wierzbicka 1974, Alcina y Blecua (1975) 2001, Authier y Meunier 1977, Maingueneau 1981, Rivarola y Reisz de Rivarola 1984, Reyes 1984, 1993 y 1994a, Coulmas 1985, 1986 y 1994, Hand 1991, Maldonado 1991 y 1999, entre muchos otros.

${ }^{22}$ Por ejemplo, Genette (1972) 1989: 228 y (1993) 1998: 36-37, Page 1973: 35-37, McHale 1978: 258, Leech y Short 1981: 323-324, Cohn 1981, Verschueren 1985, Short 1988: 64, Wales 1989: 314-315, Chafe 1994, Waugh 1995: 160, Schaeffer (1995) 1998: 658-659.

${ }^{23} C f$. Reyes 1993: 9, Collins 2001: 97 y Sakita 2002: 9, entre otros.

24 Entre otros, Jespersen (1924) 1968, Banfield 1973, Partee 1973, Wierzbicka 1974, Authier y Meunier 1977, Comrie 1986, Li 1986, Hand 1991.

${ }^{25}$ Por ejemplo, R AE (1931) 1962 y 1973, Gili Gaya 1967, Alcina y Blecua (1975) 2001.

${ }^{26}$ Obviamente, en este trabajo no tienen lugar los aspectos fónicos: se centra en una variedad de lo que Benveniste (2002 [1974]: 91) llamó "enunciación escrita". Muy poco se ha dicho del discurso ajeno en la lengua hablada: quizá el de Tannen (1989) sea el trabajo
} 
de alusión o presencia, quedan comprendidos, pues, los términos discurso referido y discurso reproducido.

Veamos algunos ejemplos. Los titulares de la serie (1) aluden a un mismo acto lingǘstico: el presidente de Venezuela, Hugo Chávez, criticó al presidente de Colombia, Álvaro Uribe, por suscribir un acuerdo militar con Estados Unidos. Los de la serie (2), en cambio, se refieren a cierta declaración del ex futbolista brasileño Pelé según la cual este se considera mejor jugador que el argentino Maradona. Loc 2 es, en (1a) y (1b), Hugo Chávez, y en (2a) y (2b), Pelé. En los cuatro casos, Loc 1 es el periodista que redactó cada encabezado (el de El Tiempo en [1a], el de El Universal en [1b], el de La Nación en [2a] y el de La Opinión en [2b]):
(1) a. 'Uribe se bajó los pantalones', dice Chávez [TPO 18/01/10: 1-7]
b. Hugo Chávez arremete contra Colombia [UNI 18/01/10: A26]
(2) a. Pelé dice que él fue el mejor [LAN 18/01/10: 63A]
b. Pelé se enaltece [OPI 18/01/10: 5C]

Dado que en los cuatro titulares hay un Loc 1 que alude a la enunciación de un Loc 2, estamos ante casos de discurso ajeno. En (1a), Loc 1 intenta repetir, en una oración subordinada, el enunciado originario, con lo cual se cumple, desde luego, la condición de representatividad: nos hallamos ante un caso de discurso reproducido. Si bien en (2a) se reformula el contenido del enunciado originario de Loc 2, nos encontramos también ante un ejemplo de discurso reproducido, pues se representan — aunque de manera menos icónoica - las palabras ajenas. En los ejemplos (1b) y (2b), en cambio, no se persigue reproducir el enunciado de Loc 2, sino informar de su existencia, aparentemente constatada por Loc 1, sin pretensión de representatividad alguna: solo es discurso referido. Con palabras de Voloshinov, en (1a) y (2a) un enunciado se halla dentro de otro enunciado, mientras que en (1b) y (2b) un enunciado trata acerca de otro enunciado. Claro está que en (1a) y (2a) hay (Kvavik 1986). 
también referencia, pero en (1b) y (2b) no hay representatividad (al menos en los términos en que la hemos definido aquí).

(3) a. Zelaya confirma que el 27 de enero dejará su país [UNI 24/01/10: A22]

b. Manuel Zelaya se irá de Honduras este miércoles [MER 24/01/10: A10]

Los titulares de la serie (3) aluden a las palabras del depuesto presidente hondureño Manuel Zelaya con las que informó que su exilio iniciaría el miércoles 27 de enero. En contraste con (3a), (3b) no podría interpretarse como discurso ajeno si se analizara fuera de contexto: podría suponerse que el origen de la información expresada es Loc 1, es decir, el periodista (y no Zelaya). Al igual que en (3a), Loc 1 representa el contenido de las palabras de Loc 2; pero, a diferencia de (3a), no lo indica explícitamente en el texto. No es sino en el contexto, en este caso, donde se hallan los indicios de una enunciación ajena en la propia: sin atender este punto no podría efectuarse una adecuada caracterización semántica del enunciado. He aquí la entrada —el primer párrafo_ - de la nota informativa encabezada por (3b):

El Presidente depuesto de Honduras, Manuel Zelaya, confirmó que abandonará su país este miércoles 27 de enero, cuando asuma el poder el Mandatario electo Porfirio Lobo, para viajar a Santo Domingo y luego radicarse en México. [MER 24/01/10: A10]

Aunque volveremos a este punto, los ejemplos de la serie (3) evidencian que el discurso ajeno debe concebirse como un fenómeno discursivo, y no como un asunto estrictamente oracional, como han hecho hasta ahora casi todos los gramáticos. Esto implica que, para poderlo describir, caracterizar y explicar adecuadamente, es necesario apelar a la interdisciplina. Brown y Yule, ${ }^{27}$ Van Dijk, ${ }^{28}$ Schriffrin, ${ }^{29}$ Georgakopoulou ${ }^{30}$ y Récanati, ${ }^{31}$ entre muchos otros, han destacado la imposibilidad de análisis discursivos circunscritos por marcos

\footnotetext{
${ }^{27}$ Brown y Yule (1983) 1993.

${ }^{28}$ Van Dijk 1985: 5.

${ }^{29}$ Schriffrin 1994: 419.

${ }^{30}$ Georgakopoulou 1997: 29.

${ }^{31}$ Récanati 2001: 663.
} 
teórico-metodológicos inflexibles y, por ende, limitados. ${ }^{32}$ Bien ha dicho Coulmas $^{33}$ que un estudio del discurso ajeno sujeto únicamente a estructuras gramaticales, que no trascienda las artificiales fronteras disciplinarias, no podrá dar cuenta de las complejidades que conlleva el tema. Además, Perfetti et al. ${ }^{34}$ han comprobado experimentalmente que una adecuada interpretación de los titulares periodísticos exige procesos de decodificación en diversos niveles de lengua.

Por cuanto la situación comunicativa predominante en las noticias periodísticas consiste en que alguien informa sobre lo dicho por otra persona, los titulares de discurso ajeno son especialmente abundantes. Ya sea porque para informar de la realidad hay que acudir a lo que dicen otros o porque la realidad de la que hay que dar cuenta son actos de habla de personajes relevantes, los periodistas construyen su propio decir a partir de actos de habla ajenos. Se trate o no de una moda importada del periodismo radiofónico, ${ }^{35}$ esta rutina informativa, hoy generalizada en todo el mundo hispánico, ocasiona que el $60 \%$ de los titulares describa un acto discursivo ajeno.

\footnotetext{
32 Georgakopoulou (1997: 29) advierte: "Discourse analysis is not a strictly unified discipline with one or few dominant theories and methods of research; instead, it exhibits a multiplicity of approaches and interdisciplinarities. [...] Interdisciplinary study is indispensable, since it is almost impossible to separate discourse from its uses in the world and in social interactions; as a result, linguistic tools alone are not sufficient for its comprehensive study". En el mismo sentido, Van Dijk (1985: 5) apunta: "An interdisciplinary approach to discourse cannot be limited to structural analysis of its various levels or dimensions but also needs to pay attention to cognitive process and to memory representations of discourse. Storage, retrieval, cognitive strategies, memory limitations, and effective organization procedures for information processing become relevant in such an account".

${ }^{33}$ Coulmas 1986.

${ }^{34}$ Perfetti et al. 1987.

${ }^{35}$ Grijelmo 2003: 48-49.
} 


\subsection{Metodología y características del corpus}

Para este trabajo recabé un corpus de 3689 titulares. Esta cifra representa el total de encabezados de nota informativa que, con indicios claros de discurso ajeno en el texto o contexto lingüístico, fueron publicados durante la semana del 18 al 24 de enero de 2010 en todas las secciones informativas de los diarios El País, de Madrid (España); La Opinión, de Los Ángeles (Estados Unidos); El Universal, de México (México); La Nación, de San José (Costa Rica); Hoy, de Santo Domingo (República Dominicana); ${ }^{36}$ El Tiempo, de Bogotá (Colombia); El Nacional, de Caracas (Venezuela); El Comercio, de Lima (Perú); El Mercurio, de Santiago (Chile), y Clarín, de Buenos Aires (Argentina). La proporción de titulares con discurso ajeno fue, en todos estos periódicos, superior al $40 \%$.

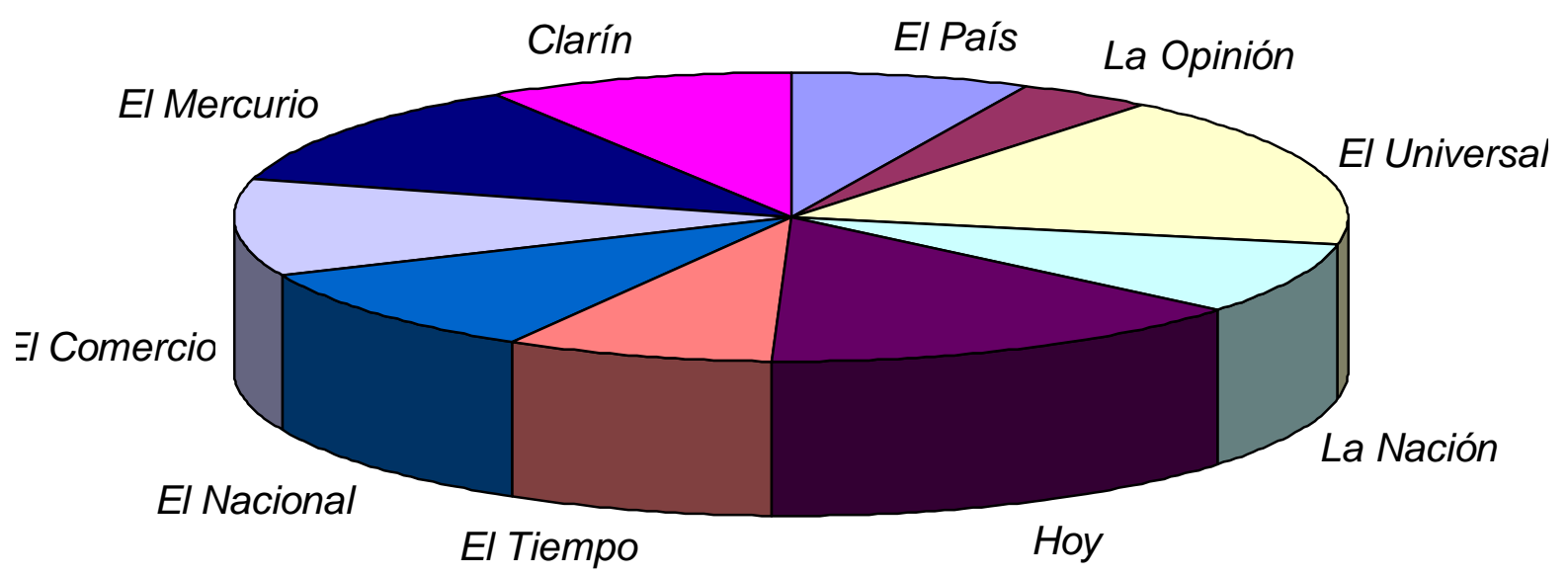

Composición del corpus

Los diez periódicos finalmente considerados integran el corpus en las proporciones siguientes: El País (Madrid), 6,9\% (253/3689); La Opinión (Los Ángeles), 4,0\% (149/3689); El Universal (México), 17,1\% (630/3689); La

\footnotetext{
${ }^{36}$ Debido a que el periódico Hoy no se publicó el martes 19 de enero, en su lugar fue incluida la edición del martes 26 de enero.
} 
Nación (San José de Costa Rica), 8,2\% (301/3689); Hoy (Santo Domingo), 14,4\% (531/3689); El Tiempo (Bogotá), 7,8\% (286/3689); El Nacional (Caracas), 10,1\% (372/3689); El Comercio (Lima), 10,8\% (400/3689); El Mercurio (Santiago de Chile), 11,8\% (436/3689); Clarín (Buenos Aires), $9,0 \%(331 / 3689)$.

Los diarios seleccionados son los de mayor circulación o mayor tradición de entre los que registraron una mayor incidencia de discurso ajeno durante el diseño y la prueba de instrumento. Con este fin reuní cuatro muestras correspondientes a los años 2004, 2005, 2007 y 2009. En este proceso fueron consideradas diversas ediciones de los periódicos españoles Abc, El Mundo, El País, La Vanguardia y Público, así como de los rotativos mexicanos Diario de México, Diario Monitor, El Día, El Diario DF, El Financiero, El Gráfico, El Sol de México, El Universal, Esto, Excélsior, La Afición, La Crisis, La Jornada, La Prensa, La Primera Ovaciones, Milenio Diario, Ovaciones Deportivo, Récord, Reforma y Unomásuno. También fueron tomadas en cuenta las siguientes publicaciones: Clarín (Argentina), El Comercio (Perú), El Diario (Bolivia), El Espectador (Colombia), El Mercurio (Chile), El Nacional (Venezuela), El Nuevo Día (Puerto Rico), El Nuevo Herald (Estados Unidos), El País (Uruguay), El Tiempo (Colombia), El Tiempo (Honduras), El Universal (Venezuela), El Universo (Ecuador), Granma (Cuba), Hoy (República Dominicana), La Nación (Argentina), La Nación (Costa Rica), La Opinión (Estados Unidos), La Prensa (Nicaragua), La Prensa (Panamá), La Prensa Gráfica (El Salvador), La Raza (Estados Unidos), Prensa Libre (Guatemala) y Última Hora (Paraguay). ${ }^{37}$

Para el análisis cuantitativo se consideran solamente los titulares de enero de 2010; sin embargo, de manera ocasional reproduzco algunos ejemplos extraídos de las muestras preliminares. De otro modo, algunos usos poco

\footnotetext{
${ }^{37}$ Cabe aclarar que en las Filipinas no se editan periódicos en español y que en Guinea Ecuatorial no se publican diarios.
} 
frecuentes, pero interesantes, quedarían inevitablemente excluidos de la caracterización general.

El corpus se ha restringido a titulares de nota informativa por cuanto es este, como bien se sabe, el género periodístico más abundante en los medios de comunicación. La nota informativa prototípica se caracteriza, en esencia, por una jerarquización informativa de importancia descendente en el orden discursivo, y por la pretensión de ocultar toda huella del sujeto enunciador. 


\section{LOS TITUlares PERIODíSTICOS}

Los titulares son la parte más prominente del discurso informativo impreso y, paradójicamente, uno de los aspectos del lenguaje periodístico que menos atención ha recibido por parte de los especialistas. Los manuales de periodismo, que en muchos casos no son sino recetarios de consejos prácticos sin sustento teórico, tradicionalmente han constituido los únicos intentos de sistematización de la actividad informativa. En ellos los títulos de las noticias suelen recibir apelativos más pintorescos que esclarecedores: "versos con olor a tinta", "el señuelo de la noticia", "la incitación periodística", "escaparates de la información", "la primera puerta de la noticia", "tarjetas de presentación", "la luz que atrae y fija la huidiza atención del lector". 1

Desde luego, los titulares son algo más que enunciados iniciales que encabezan un texto periodístico y que están impresos en negrillas. Sus rasgos definitorios versan en torno de una doble prominencia: gráfica y discursiva. La prominencia gráfica se debe, obviamente, a que por lo general se hallan en letras negrillas y de mayor cuerpo que las del texto que encabezan. La prominencia discursiva se debe a que, como dice Alarcos, conforman un sistema semiológico particular derivado de la lengua, pero superpuesto a ella. ${ }^{2}$ Desde luego, dicho sistema merece ser descrito.

De acuerdo con Van Dijk, entre muchos otros, "los titulares son la parte más importante del texto"4 informativo: además de sintetizar (por lo general) e

\footnotetext{
${ }^{1}$ Cf. SIP 1965: 83, Johnson y Harriss (1942) 1966: 279, Muñiz Chacón 1990: 215, Martín Vivaldi 1998: 220, Pou Amérigo 2004: 239, entre otros

${ }^{2}$ Alarcos 1977: 130.

${ }^{3}$ Por ejemplo, Fontcuberta 1993: 117, Guntern Weibel 2000: 1952, López Hidalgo 2009: 57, Hurtado 2009: 191.

${ }^{4}$ Van Dijk (1988a) 1997: 134.
} 
identificar el texto que encabezan, orientan su interpretación, como también ha advertido Eco. "Tanto semántica como esquemáticamente, además de por su organización, el titular es el número uno", ${ }^{6}$ apunta Van Dijk. Es por ello que se trata de la única "categoría obligatoria dentro del esquema de las noticias". ${ }^{7}$ De hecho, el titular es la única unidad redaccional del periódico ${ }^{8}$ que puede aparecer escindida de las demás: los artículos informativos, por ejemplo, nunca se publican sin un encabezado contiguo, pero sí se observan titulares aislados.

Funcionan los encabezados, pues, “con cierta autonomía respecto de los textos que resumen y anuncian". 9 Debido a que gozan de independencia sintáctica $^{10} \mathrm{y}$, hasta cierto punto, semántica, los títulos de las noticias se convierten en textos en sí mismos ${ }^{11}$ que permiten conocer lo esencial de cada información. Por cuanto integran un conjunto de lectura en cierto modo autónoma e independiente, constituyen, como se sabe, las únicas secuencias leídas por gran parte de los consumidores de diarios. ${ }^{12}$ Hasta tal punto somos lectores de encabezados que algunos medios electrónicos han adoptado como una de sus funciones informativas la de, precisamente, ponernos al día en los titulares de prensa.

Puesto que a menudo los titulares remiten unos a otros $-\mathrm{y}$, claro está, a los textos que encabezan-, se ha dicho también que constituyen el punto de unión entre la intertextualidad y la textualidad. ${ }^{13}$ A causa de su indudable

\footnotetext{
${ }^{5}$ Eco 1977. Cf. Van Dijk (1980) 1990, 1983, (1988a) 1997, Thogmartin 1991, Vasilachis de Gialdino 1998: 38, Guntern Weibel 2000: 1956.

${ }^{6}$ Van Dijk (1988a) 1997: 133.

${ }^{7}$ Vasilachis de Gialdino 1998: 35-36.

${ }^{8}$ Cf. Casasús 1988.

${ }^{9}$ Gomis 1991: 28.

${ }^{10}$ Garst y Bernstein 1940: 133.

${ }^{11}$ Charaudeau 1983, Muñiz Chacón 1990.

12 Emig 1927, Vigil Vázquez 1966, Eco 1977, Casado Velarde 1984, Gomis 1991: 28, Martín Vivaldi 1998: 214, Hurtado 2003: 23, Pou Amérigo 2004: 241, López Hidalgo 2009: 16.

${ }^{13}$ Núñez Ladevéze 1979: 242-244.
} 
naturaleza ancilar, puede decirse, con Genette, ${ }^{14}$ que el encabezado es el paratexto de mayor importancia en el discurso periodístico.

Expongo en las siguientes páginas, a manera de marco de referencia, una revisión general de algunos aspectos relativos a estas partes tan importantes del discurso periodístico escrito. Luego de aclarar brevemente lo que aquí se entiende por titular, refiero sus funciones más habituales y los factores principales de los que depende su formulación. En seguida abordo el no siempre claro asunto de su autoría y presento un somero recuento histórico de los orígenes de los encabezados modernos. Finalmente propongo, sin ánimo de exhaustividad, un breve inventario de los rasgos formales de codificación linguística más característicos de este tipo de texto.

\subsection{Aclaración terminológica}

López de Zuazo define inicialmente titular como el "título de una información". ${ }^{15}$ En la jerga periodística, sin embargo, a menudo se llama titular, cabeza o cabeza de titulación al conjunto de enunciados que antecede al artículo noticioso. Desde esa perspectiva, el título es el único elemento indispensable, fácilmente identificable por imprimirse siempre con letras de mayor cuerpo. Según la publicación y la importancia atribuida a la noticia, el título puede ir acompañado por uno o más de los siguientes elementos: antetítulo o sobretítulo, subtítulo, titulillo, cintillo, sumario, flash, ladillo, título-cohete, entrada o entradilla, epígrafe, cerrojo o catenaccio, ventana y rataplán, que también gozan de cierta prominencia gráfica. ${ }^{16}$

\footnotetext{
${ }^{14}$ Genette (1987) 2001.

${ }^{15}$ López de Zuazo 1990: s.v. titular.

${ }^{16}$ Cf. Peytard 1975, Gómez Mompart 1982: 28-29, Moreno de Alba 1996: 26, Rojas Espinosa 2003, Rivadeneira Prada 2007: 170-171, López Hidalgo 2009: 33-43, entre otros.
} 
Puesto que, de todos ellos, el "título" es el único elemento esencial, en algunas ocasiones el término título se ha hecho extensivo a todo el "titular", como observa De Gregorio. ${ }^{17}$ En otras, tal como se aprecia en la definición de López de Zuazo, titular se emplea también para designar lo mismo que título (o sea, el elemento principal - y, en consecuencia, imprescindible- de la “cabeza de titulación”). Indistinciones y diferenciaciones terminológicas similares se observan también, según los autores, en el uso de las voces encabezado, cabeza y encabezamiento. ${ }^{18}$ Por cuanto ninguna distinción de todo ello resulta en realidad operativa para los objetivos de este trabajo, emplearé indistintamente todos estos términos — titular, encabezado, cabeza y encabezamiento - en exclusiva referencia al "título de una información", lo acompañen o no en la página del periódico otros enunciados de carácter accesorio que también precedan al artículo periodístico.

\subsection{Funciones de los titulares}

En cuanto título, pues, el titular desempeña lo que Genette denomina la "función de designación", 19 es decir, la de identificar un texto, en este caso periodístico. La función básica del titular $-\mathrm{y}$, al margen de criterios normativos o de idealización, la única ineludible- es, obviamente, la de distinguir los distintos textos de que se compone un diario o una revista. En otras palabras, el titular es "la etiqueta de identificación de cada elemento de un informativo". ${ }^{20}$

A partir de las funciones del lenguaje propuestas por Bühler (expresión, representación y apelación), Alarcos ${ }^{21}$ añade a la función distintiva (o de

\footnotetext{
${ }^{17}$ De Gregorio (1960) 1966: 82.

${ }^{18}$ Entre otros, Rivadeneira Prada 2007: 165, López Hidalgo 2009: 33-34, López de Zuazo 1990: s.v. título, encabezado, cabeza y encabezamiento.

${ }^{19}$ Genette (1987) 2001: 82.

${ }^{20}$ Van Dijk (1988a) 1997: 133.

${ }^{21}$ Alarcos 1977: 127.
} 
designación o identificación) las funciones referencial y expresiva. Esto es, los encabezados modernos buscan también, en principio, indicar el contenido del texto encabezado y despertar el interés del lector. ${ }^{22}$

Los titulares desempeñan muy a menudo una función referencial, descriptiva o informativa porque, en palabras de Alarcos, el encabezado es normalmente "una especie de extracto o resumen de otra manifestación lingüística más amplia y circunstanciada a la que alude concentradamente, y que está físicamente contigua". ${ }^{23}$ Es por ello que, en su modelo del esquema noticioso, Van Dijk concibe el titular como la expresión convencional de la macroproposición de la macroestructura semántica del relato informativo. ${ }^{24} \mathrm{O}$, dicho de otro modo, los títulos de las noticias suelen ser el resumen del resumen del texto que encabezan, en el entendido de que el titular suele resumir el primer párrafo de la nota informativa - llamado entrada o lead por los periodistas-, que, a su vez, es el resumen del resto del texto. En atención a tal propiedad, Garst y Bernstein ya señalaban, muchos años antes, que el titular es, "en cierto sentido, un súper-lead". ${ }^{25}$ Es esto, claro está, lo que permite a los consumidores de periódicos enterarse de las noticias leyendo solamente los encabezados.

La función expresiva, apelativa o de seducción, observable también en muchos encabezados, no es otra que la de atraer la atención y el interés del destinatario para que lea el texto que se ofrece a continuación. Esta pretensión ya era advertida en los primeros intentos de sistematización del discurso periodístico. ${ }^{26}$ Con denominaciones como "rótulo luminoso"27 o "grito de atención", ${ }^{28}$ se ha intentado poner de relieve la importancia que tienen los

\footnotetext{
${ }^{22} C f$. Richardson 2007: 197, entre otros.

${ }^{23}$ Alarcos 1977: 128. Cf. Gaillard 1972: 109, Fontcuberta 1993: 117, El Mundo 1996: 67, Escribano Hernández 2001: 21.

${ }^{24}$ Van Dijk (1980) 1990 y (1988a) 1997.

25 "The headline is, in a sense, a super lead" (Garst y Bernstein 1940: 91).

${ }^{26}$ Por ejemplo, Neal 1933: 117, Garst y Bernstein 1940: 91, De Gregorio (1960) 1966: 81.

${ }^{27}$ López Hidalgo 2009: 16.

${ }^{28}$ Fontcuberta 1993: 117.
} 
encabezados a la hora del consumo de la noticia como mercancía: "De ellos depende, entre otros aspectos, que los lectores sigan o no leyendo tanto el periódico como las noticias", ${ }^{29}$ dicen repetidamente los tratadistas del periodismo. Hay incluso quienes valoran la calidad de los rotativos en función de la capacidad de sus encabezados para despertar el interés de los lectores: "Un diario que publicase inmejorables artículos, pero presentados con malos títulos, sería un mal diario, pues... no tendía lectores". 30

El hecho de que los manuales de periodismo y libros de estilo insistan constantemente en la necesidad de que los títulos sinteticen el relato noticioso y, al mismo tiempo, llamen la atención del lector revela que no siempre es así. $^{31}$ Acaso por ello han surgido clasificaciones descriptivas como la de Muñiz Chacón, para quien los titulares pueden ser informativos o seductivos. Los primeros son, dice, los que apelan especialmente a la función referencial, descriptiva o informativa, pues, gracias a su naturaleza redundante con el contexto, permiten al lector "llegar a la noticia sin pasar por el artículo". 32 Por el contrario, los segundos, que atienden más a la función expresiva, apelativa o de seducción, obligan al receptor a leer el artículo si quiere enterarse del contenido, ya que en estos casos la relación entre texto y encabezado "se puede definir como una correspondencia no aplicativa en la que a cada elemento del mensaje le pueden corresponder varias interpretaciones distintas, que el destinatario, a priori, no podrá dilucidar". ${ }^{33}$ Núñez Ladevéze ${ }^{34}$ ha propuesto clasificar los titulares no informativos ("seductivos" para Muñiz Chacón) en expresivos y apelativos según se encaminen a expresar los

${ }^{29}$ Gómez Mompart 1982: 9. Cf., entre otros, Rojas Espinosa 2003, López Hidalgo 2009, Bell 1991: 189.

${ }^{30}$ Gaillard 1972: 109. Cf. Grijelmo 2003: 455.

${ }^{31}$ Cf. Vasilachis de Gialdino 1998: 37. Ya observó Genette ([1987] 2001: 51-83) que en realidad son facultativas las funciones descriptiva y de seducción (es decir, referencial y expresiva) -frecuentemente aludidas en lo que él llama la "titulogía moderna"-, aunque reconoce que la primera de ellas llega a ser inevitable.

${ }^{32}$ Muñiz Chacón 1990: 217.

${ }^{33}$ Ibid. Cf. Guntern Weibel 2000: 1957.

${ }^{34}$ Núñez Ladevéze 1995: 62-63. 
sentimientos que la noticia suscitará en los receptores o bien a reforzar o modificar actitudes de los lectores.

Hurtado coincide en distinguir los titulares que sintetizan la información, que también denomina informativos, de "aquellos que buscan sobre todo la evocación cuasi-literaria", ${ }^{35}$ que llama creativos, pero acertadamente reconoce que no son categorías mutuamente excluyentes. De hecho, en opinión de Gomis, ${ }^{36}$ entre muchos otros, ${ }^{37}$ un buen titular puede servir para dos cosas aparentemente contrarias: para incitar al receptor a leer la información que viene en seguida o para darla por sabida y continuar adelante.

Condicionados por factores architextuales, los titulares modernos suelen privilegiar claramente la función informativa, referencial o descriptiva cuando encabezan, como es obvio, notas informativas. Salvo en periódicos sensacionalistas, deportivos y de espectáculos, ${ }^{38}$ estos titulares por lo general expresan la macroestructura semántica de la noticia, ${ }^{39}$ aunque ello en ocasiones pueda suponer, hasta cierto punto, un no tan claro cumplimiento de la función expresiva, apelativa o de seducción.

\subsection{Condicionantes de los titulares}

Los titulares se formulan, evidentemente, en relación con el texto que encabezan y con la situación en que se producen. Resultante de un complejo proceso multicausal, su codificación lingüística se encuentra sometida a estrategias discursivas específicas ${ }^{40}$ que representan respuestas pragmáticas a

\footnotetext{
${ }^{35}$ Hurtado 2009: 192.

${ }^{36}$ Gomis 1989: 142.

${ }^{37}$ Por ejemplo, Neal 1933: 117, Garst y Bernstein 1940: 91, Escribano Hernández 2006: 17, López Hidalgo 2009: 28.

${ }^{38}$ Núñez Ladevéze 1995: 62, López Hidalgo 2009: 49-51.

${ }^{39}$ Van Dijk (1980) 1990 y (1988a) 1997.

${ }^{40}$ Cf. Tilby 1977: 313 .
} 
una serie de factores que concurren en la enunciación. Además — claro estáde la lengua empleada, la intención comunicativa y la información noticiosa, en el proceso son determinantes el espacio disponible, la contigüidad o no con el texto que encabezan o con imágenes, los conocimientos previos que se suponen en el lector, el género periodístico, la publicación y su periodicidad, el momento, la orientación o ideología del medio informativo, el grado de libertad de expresión, la tradición periodística y cultural, las normas internas de redacción (a veces hechas públicas y comercializadas como "libros de estilo"), la sección o la página en que se inserta la noticia y hasta el cuerpo y tipo de letra. ${ }^{41}$

Es importante insistir en que la configuración linguiística de los titulares varía notablemente según el tipo de publicación y del género periodístico rotulado ${ }^{42}$ (nota informativa, entrevista, crónica, reportaje, artículo, etcétera). Por ejemplo, los géneros informativos, como la nota, tienden a ostentar encabezados con verbo explícito con mayor frecuencia que los llamados géneros interpretativos (crónica, reportaje) o de opinión (artículo, editorial), ${ }^{43}$ especialmente, entiende López Hidalgo, "si el periódico pretende gozar de un cierto rigor". ${ }^{44}$ Sirva también como ejemplo el hecho, ya advertido por Garst y Bernstein hace muchos años, ${ }^{45}$ de que los periódicos más conservadores tienden a evitar en sus titulares usos pertenecientes a registros coloquiales de la lengua, en contraste con los diarios más populares o sensacionalistas. Y es que, en buena medida, la manera de redactar titulares es diferente en cada

\footnotetext{
${ }^{41}$ Cf. Casado Velarde 1984: 237, Gómez Mompart 1982: 53-68.

${ }^{42}$ Gómez Mompart 1982, Martín Vivaldi 1998 y 2000, Grijelmo 2003, Rojas Espinosa, 2003, Pou Amérigo, 2004, López Hidalgo 2009, por ejemplo.

${ }^{43}$ Cf. Armentia Vizuete y Caminos Marcet 1998: 150, López Hidalgo 2009: 52. Fontcuberta (1993: 124) reconoce acertadamente que también hay títulos informativos sin verbo, que denomina "estáticos".

${ }^{44}$ López Hidalgo 2009: 113.

${ }^{45}$ Garst y Bernstein 1940: 145.
} 
periódico ${ }^{46}$ y "se relaciona con las expectativas del sector social al cual se dirige". 47

La posición del periodista y del medio es también determinante, ya que, en palabras de Van Dijk, "las ideologías subyacentes [...] afectan las estructuras formales del lenguaje". ${ }^{48}$ Debido a que encabezar una noticia no es una actividad ingenua, pues "es intencional y satisface los intereses de la empresa", ${ }^{49}$ la configuración lingüística de los titulares obedece, indudablemente, a intereses ideológico-políticos, socio-culturales y empresario-comerciales del medio de comunicación, los cuales suelen presentarse de manera velada ${ }^{50}$. Como afirma Guntern Weibel, "podemos hablar de una élite que controla la información pública o la comunicación social y aquí los titulares cumplen un papel fundamental, ya sea como 'llamadores' de lectura o como forma de condicionar dicha lectura". ${ }^{51}$

Los titulares son, dice Van Dijk, ${ }^{52}$ el lugar predilecto para las opiniones implícitas. Por esta razón, el análisis de los titulares puede proporcionar datos de interés acerca de "los valores e ideologías de los periodistas y de los periódicos, y, especialmente, de la manera como los lectores entenderán, memorizarán y usarán la información de la noticia para la elaboración de su conocimiento y opiniones acerca de la realidad" ${ }^{, 53}$ (recuérdese que, a pesar de las aparentes pretensiones de objetividad del periodismo, los informadores adaptan sus puntos de vista y sus valores a las exigencias de las organizaciones informativas, que en este aspecto no suelen ser sino instrumentos de legitimación y sostenimiento de las estructuras de poder de

\footnotetext{
${ }^{46}$ Castelli 1981: 150, Guntern Weibel 2000: 1956, López Hidalgo 2009: 62. Cf. Garst y Bernstein 1940: 91.

${ }^{47}$ Guntern Weibel 2000: 1956.

${ }^{48}$ Van Dijk 2003: 68-69.

${ }^{49}$ Romero Álvarez 2009: 23.

${ }^{50}$ Alarcos 1977, Van Dijk 1983, 1997, Fowler 1991, entre otros.

${ }^{51}$ Guntern Weibel 2000: 1952.

${ }^{52}$ Van Dijk 1983: 86.

${ }^{53}$ Ibid.: 78. Cf. Alarcos 1977: 139.
} 
las sociedades). ${ }^{54}$ En definitiva, es posible decir, con Gómez Mompart, que "un título es ya una información y, a su vez, es también una opinión”. 55

Con los encabezados, sostiene Gomis, ${ }^{56}$ el periodismo trata de persuadirnos de que suceden cosas interesantes. Su propósito es, dice, interesarnos, atraer nuestra atención, impresionarnos, conseguir que reflexionemos y que hablemos del tema en cuestión. Siguiendo los planteamientos de este autor, Fontcuberta refiere que los titulares de textos informativos buscan cumplir tres objetivos: "Anunciar y resumir la información que va en la noticia; convencer de que aquello que se cuenta es interesante; y evadirse de la propia información que resumen, cobrar vida propia, resultar inteligibles por sí mismos, de modo que el lector, apenas leído el titular, pueda ya contar el hecho". 57

Acaso las restricciones de espacio son el factor más notorio que condiciona la formulación de los encabezados. Producidos en situaciones enunciativas que llevan al límite la tensión entre economía e informatividad, los titulares modernos se ajustan, según se presume, al espacio exacto delimitado previamente por la maqueta (es decir, el boceto previo del diseño de la página): en principio, no debe excederlo, pero tampoco quedarse corto. ${ }^{58}$ Con fundamento en la idea de que "la noticia que necesita un titular largo suele resultar menos atractiva", ${ }^{59}$ los libros de estilo y los manuales de redacción periodística suelen recomendar que los títulos no excedan las diez, doce o trece palabras: no más de diez para Gómez Mompart, ${ }^{60}$ de diez a doce para Secanella ${ }^{61}$ y Martín Vivaldi, ${ }^{62}$ y no más de trece para los redactores del libro

${ }^{54}$ Cf. Epstein 1974, Enwall 1978, Sigal (1973) 1979, Van Dijk 1988b y (1980) 1990, Rodrigo 1989, Fowler 1991, Fonte 2002, entre muchos otros.

${ }^{55}$ Gómez Mompart 1982: 9

${ }^{56}$ Gomis 1991: 27-34.

${ }^{57}$ Fontcuberta 1993: 117.

${ }^{58}$ Ibid: 127.

${ }^{59}$ López Hidalgo 2009: 70.

${ }^{60}$ Gómez Mompart 1982: 119.

${ }^{61}$ Secanella 1980: 58. 
de estilo de El País, ${ }^{63}$ por ejemplo (pero en realidad, como algunos bien han observado, ${ }^{64}$ muy a menudo se aproximan o incluso rebasan las quince palabras).

El espacio asignado en la maqueta $-\mathrm{y}$, por consiguiente, la extensión final del titular - depende de diversos factores. Uno muy destacado es lo que Núñez Ladevéze llama el "principio de proporcionalidad del título"65 con respecto a la importancia de la noticia: es un hecho semiológicamente codificado que los textos periodísticos ocupen más o menos columnas "según que su contenido sea considerado por el emisor más o menos interesante" ${ }^{66}$ A noticias evaluadas como más importantes o llamativas, titulares más grandes.

A ello han de añadirse el formato o tamaño del periódico (esto es, las dimensiones de la hoja de papel), la familia tipográfica y el cuerpo de las letras empleadas en la confección del encabezado, amén de "si [este] es de caja alta (mayúsculas) o de caja baja (minúsculas), si las letras van en redonda o en cursiva". ${ }^{67}$ Para la composición del titular, los periodistas deben hacer cálculos y tomar decisiones a partir no solo de los distintos tamaños que poseen las diversas realizaciones de cada grafema, sino incluso de las a veces mínimas diferencias que hay entre las distintas letras del abecedario (de un mismo tipo, cuerpo y familia), signos de puntuación, cifras y espacios en blanco:

El cómputo de las señales tipográficas (letras) y de los espacios se rige para la confección de títulos en las medidas de cada elemento; por ejemplo, en letras largas como la "I" vale media unidad; la "M" y "W", una y media unidades; todas las demás letras, una unidad; los signos de puntuación, la cifra 1 y los espacios entre palabras,

\footnotetext{
${ }^{62}$ Martín Vivaldi 1998: 216 y 2000: 378.

${ }^{63}$ El País 2003: 52. Cf. El Mundo 1996: 69.

${ }^{64}$ Núñez Ladevéze 1995: 65.

${ }^{65}$ Ibid.

${ }^{66}$ Girón Alconchel 1993: 194-195. Cf., entre muchos otros, López Hidalgo 2009: 73, De Gregorio (1960) 1966: 82.

${ }^{67}$ López Hidalgo 2009: 80.
} 
media unidad y las cifras del 2 al 0, una unidad. En letras bajas, las valencias son: las letras "i", "f", "l” y " $\mathrm{t}$ ", los signos de puntuación y la cifra 1, media unidad. Para "m" y "w", una unidad y media. Todas las demás letras, una unidad. ${ }^{68}$

Es evidente, pues, que, si bien propiamente se trata de productos verbales, los encabezados están condicionados de manera parcial por las artes gráficas y por el diseño visual del periódico. ${ }^{69}$ Es por ello que Verón ha propuesto considerarlos un tipo de "serie visual paralingüística" ${ }^{70}$ De hecho, a juicio de Casasús, ${ }^{71}$ la prensa contemporánea se compone de "unidades redaccionales" que combinan dos o tres elementos, en configuraciones como titular-texto o titular-texto-ilustración.

En definitiva, por su carácter protagonista, por sus funciones y por las circunstancias que condicionan su publicación, el titular es, según suelen decir los informadores, "uno de los elementos más difíciles de dominar en la redacción de textos periodísticos". ${ }^{72}$ Para López Hidalgo, la redacción de encabezados es "una tarea que nunca deja de ser asignatura pendiente de muchos periodistas", 73 por lo que, apunta Rojas Espinosa, esa labor "constituye hoy en día una especialidad dentro de la práctica periodística", 74 llena de exigencias que varían notablemente de un diario a otro. ${ }^{75}$

\section{4. ¿Quién redacta los titulares?}

Obviamente, el proceso de elaboración de los titulares no es igual en todas partes, pues depende de la estructura organizativa particular de cada

\footnotetext{
${ }^{68}$ Rivadeneira Prada 2007: 167.

${ }^{69}$ Martínez Albertos 2001: 416, entre otros.

${ }^{70}$ Verón 1984: 146. Cf. Girón Alconchel 1993: 192-193.

${ }^{71}$ Casasús 1988: 116.

${ }^{72}$ Pou Amérigo 2004: 253. Cf. Vigil Vázquez 1966: 203, entre muchos otros.

${ }^{73}$ López Hidalgo 2009: 171.

${ }^{74}$ Rojas Espinosa 2003: 13.

75 Neal 1933: 106, Garst y Bernstein 1940: 91 y 124. Cf. Gómez Mompart 1982, López Hidalgo 2009, entre otros.
} 
periódico. A pesar de ello, se observan hoy dos claras tendencias relativas a la autoría de los encabezados, las cuales, de cualquier manera, ponen en evidencia que la decisión del título final nunca es un derecho del propio autor del texto informativo, como tal vez podría suponerse.

Una tendencia muy extendida es la de contar, en los periódicos, con personas especializadas en la redacción de titulares. Como acabamos de referir, en el gremio suele asumirse que no todos los periodistas son diestros en esa tarea: "Para ello se requieren unas disposiciones particulares y una larga experiencia", ${ }^{76}$ dice Gaillard, por ejemplo. En los periódicos bien organizados —opina Martín Vivaldi-, ${ }^{77}$ la elaboración de los titulares no suele correr a cargo del autor del artículo: se trata, de acuerdo con Bond, ${ }^{78}$ de una labor colectiva tradicionalmente reservada a los jefes de redacción y a los correctores. En Estados Unidos, origen — no se olvide- del periodismo moderno, denominan copy editor o copy reader al empleado que se encarga, entre otras actividades, de redactar encabezados. ${ }^{79}$ Calvimontes los llama "cabeceros o tituladores". 80

En los diarios que adoptan este sistema de trabajo, los reporteros entregan sus textos sin título de ninguna clase. ${ }^{81}$ Vigil Vázquez asegura que una de las tareas del periodista es, precisamente, leer trabajos ajenos sin titular para después asignarles un encabezado. ${ }^{82}$ A juicio de Martínez Albertos, ${ }^{83}$ así debe ser. En su primer Manual de estilo, la Sociedad Interamericana de Prensa justificaba esta práctica de la siguiente manera: "La distancia indispensable entre la propia obra y su rotulación no la logra el creador de ella, sino quien

\footnotetext{
${ }^{76}$ Gaillard 1972: 109.

${ }^{77}$ Martín Vivaldi 1998: 227.

${ }^{78}$ Bond, 1996: 205-206. Cf . Martín Vivaldi 2000: 334.

${ }^{79} C f$. por ejemplo, Neal 1933, Garst y Bernstein 1940.

${ }^{80}$ Calvimontes 1994: 36.

${ }^{81}$ Por ejemplo, Marín (2006: 100), director general editorial del periódico mexicano Milenio Diario, asevera tajantemente: "El reportero nunca escribe las cabezas o titulares de las notas informativas" (las cursivas son mías).

${ }^{82}$ Vigil Vázquez 1966: 203.

${ }^{83}$ Martínez Albertos 1991: 17.
} 
juzga con mirada crítica, libre de antecedentes" ${ }^{84}$ También suele decirse que, al desconocer el resto de las noticias del día, el reportero es incapaz de valorar su trabajo en relación con los demás contenidos de la edición, ya que la importancia asignada por la empresa informativa a cada texto suele estar visualmente diferenciada, como hemos dicho, por el tamaño del titular y la página donde se publica, lo cual acarrea inevitables restricciones para la formulación del encabezado. Y es que, según palabras de Vigil Vázquez, "se titula no sólo con una frase feliz y acertada, sino también con la misma tipografía elegida para su impresión y con el lugar en el periódico donde se inserta la noticia". ${ }^{85}$

La otra tendencia, aparentemente más reciente, apunta a que sea el propio autor del texto informativo quien proponga una primera versión del título y que después el jefe de sección, el redactor jefe o incluso el subdirector o director lo modifiquen si lo consideran oportuno. En opinión de López Hidalgo, lo lógico es que el autor titule su propio texto. "É "Él ha de aportar 'su' idea, 'su' pista adecuada sobre la esencia de lo que quiere contar", ${ }^{87}$ asevera Grijelmo, y añade: "Procurará que los editores lo den por bueno por la sencilla razón de que lo es". ${ }^{88}$ Se deduce, por consiguiente, que la intención con esta rutina de trabajo es justamente la contraria: aquí se trata de persuadir a los superiores de la relevancia atribuible al relato informativo o a algún aspecto en él contenido. Estos dos autores incluso recomiendan empezar a redactar las notas informativas por el título (según Fontcuberta, ${ }^{89}$ los reporteros suelen tener en mente el titular antes de escribir la primera letra del texto). García Núñez entiende, en la misma dirección, que lo más adecuado es el que los autores entreguen su trabajo con título, ${ }^{90}$ aunque ese encabezado

\footnotetext{
${ }^{84}$ SIP 1965: 90.

${ }^{85}$ Vigil Vázquez 1966: 203.

${ }^{86}$ López Hidalgo 2009: 114.

${ }^{87}$ Grijelmo 2003: 455.

${ }^{88}$ Ibid.

${ }^{89}$ Fontcuberta 1993: 126.

${ }^{90}$ García Núñez 1985: 45.
} 
sufra con mucha frecuencia importantes modificaciones posteriores. Este último hecho, insiste López Hidalgo, "no es óbice para que el redactor entregue su trabajo sin titular". ${ }^{91}$

En España se adopta por lo general esta segunda manera de trabajar. Según una encuesta realizada entre miembros de las redacciones de los rotativos $E l$ País, Abc, El Mundo, Diario 16, La Vanguardia y El Periódico, ${ }^{92}$ lo más habitual es que el autor del texto proponga un titular a fin de orientar al responsable de la sección, el cual decide el encabezado definitivo, salvo que la noticia se juzgue merecedora de un lugar en la primera página, en cuyo caso intervienen también el director o el subdirector del periódico, que tienen la última palabra. Dependiendo de la estructura organizativa de la empresa informativa, en algunas ocasiones, sin embargo, la propuesta inicial es realizada por el jefe de sección, el redactor jefe o incluso el subdirector, ya sea en solitario o en conjunto, y, en el caso de los titulares de la primera plana, que siempre son prerrogativa del director, este puede compartir la tarea con el subdirector, el redactor jefe, el jefe de sección o con todos a la vez.

Ya sea que se trabaje de una u otra manera, los titulares son, pues, textos de elaboración colectiva. Por su importancia y su prominencia dentro del discurso periodístico, los encabezados pasan por diversas manos y experimentan sucesivas correcciones antes de ser impresos, particularmente si se sitúan en las páginas más destacadas. Dentro de la elaboración de los materiales de los periódicos, la tarea de redactar titulares es, sin duda, la que más profesionales y de más alto rango concita. En esta investigación, se considerará el emisor del texto (Loc 1) la última persona que lo corrige o lo autoriza, ya se trate del jefe de sección, del redactor jefe, del subdirector, del director o de alguien más, que, a fin de cuentas, produce un mensaje de carácter institucional.

\footnotetext{
${ }^{91}$ López Hidalgo 2009: 58.

${ }^{92}$ Zorrilla Barroso 1996: 358-380.
} 


\subsection{Orígenes de los titulares modernos}

Antiquísimos son los títulos en cuanto expresiones lingüísticas con que se da a conocer el nombre o el asunto de un texto. Sin embargo, los titulares periodísticos de los géneros informativos, tal como hoy los concebimos - es decir, que por lo general destacan aspectos particulares del texto que encabezan o los refunden en un enunciado sin aludir únicamente al tema general y que en ocasiones se extienden a todo lo ancho de la página del periódico_- son un invento estadounidense del siglo XX exportado de ahí a todo el mundo. "Cualquier esbozo de la historia del titular tiene que ver con el periodismo estadounidense", 93 advierten por ello, con razón, Garst y Bernstein.

En los inicios de periodismo, los textos se publicaban encabezados por un rótulo genérico sin verbo: "Sucesos varios" o "La gira del presidente", por ejemplo. Esto es, aquellos títulos expresaban apenas el tema general y no la información novedosa, como acaso sería, en este segundo ejemplo, lo que efectivamente sucedió en la gira (quizás "El presidente advierte en su gira que no cederá ante chantajes"). Con fundamento en las teorías lingüísticas de la estructura informativa (pero, eso sí, con respecto a títulos de obras literarias), autores como Genette ${ }^{94}$ han propuesto establecer una distinción entre títulos temáticos y títulos remáticos según sea que aporten información genérica o más novedosa.

Si bien Garst y Bernstein refieren un ejemplo de uso de la técnica moderna (título "remático") de 1781 publicado en el periódico The Boston Gazette y algunos más aparecidos durante la guerra de Secesión para dar cuenta de las noticias de los distintos frentes, advierten que los titulares modernos son, en

\footnotetext{
93 "Any sketch of the history of the headline concerns itself with American journalism" (Garst y Bernstein 1940: 93).

${ }^{94}$ Genette (1987) 2001: 72-79.
} 
realidad, fruto de la guerra de Cuba, de 1898. También en este último conflicto empezaron a publicarse, de manera más o menos habitual, titulares extendidos a lo ancho de las columnas de los periódicos; pero, concluyen Garst y Bernstein, no fue hasta la Primera Guerra Mundial cuando tal solución gráfica se convirtió en algo realmente característico de las planas de los diarios. ${ }^{95}$

Gomis ${ }^{96}$ señala que, en España, los encabezados modernos son una novedad importada tardíamente de Estados Unidos. En el siglo XIX, asegura Ruiz Acosta, ${ }^{97}$ los titulares o bien no existían en los periódicos españoles o eran breves sintagmas nominales, frecuentemente de una sola palabra, que no representaban el contenido del texto. Hasta las primeras décadas del siglo XX, las noticias importantes se hallaban sueltas "entre el mazacote de las secciones, apreciándose un titular neutro y anodino y a continuación varias notas sin epígrafes separadas por un breve guión". 98 Progresiva a lo largo de todo el siglo XX, la evolución de los titulares hacia lo que hoy conocemos empezó a ser evidente a partir de la década de los cincuenta, ${ }^{99}$ aunque no sin importantes irregularidades hasta prácticamente los años setenta. ${ }^{100}$

Entre los factores que determinaron los cambios en los titulares están, de acuerdo con Ruiz Acosta, ${ }^{101}$ la aplicación cada vez mayor de los adelantos técnicos, como el telégrafo y el teléfono, y el surgimiento del periodismo industrial, es decir, nuevos medios de comunicación que, integrados a grupos empresariales más o menos poderosos, se conciben como negocios que buscan ganar dinero comercializando contenidos informativos.

\footnotetext{
${ }^{95}$ Garst y Bernstein 1940: 93-96.

${ }^{96}$ Gomis 1989: 138-139.

${ }^{97}$ Ruiz Acosta 1992: 80.

${ }^{98}$ Martínez Rivera 1994: 30.

${ }^{99}$ López Hidalgo 2009: 26

${ }^{100}$ Canga Larequi 1994: 30.

${ }^{101}$ Ruiz Acosta 1992: 80.
} 


\subsection{La configuración linguiística de los titulares}

Garst y Bernstein decían que el titular moderno "habla un lenguaje propio". ${ }^{102}$ Con esto se referían a que los encabezados de los periódicos se formulan usando el código linguiístico general, pero ampliado con algunas convenciones adicionales, utilizadas solamente en este tipo de discurso a fin de satisfacer necesidades particulares. En el mismo sentido, Alarcos señaló, años después, que los títulos de las noticias conforman "un sistema semiológico particular que aunque derivado de la lengua se superpone a ésta". ${ }^{103}$

Algunos han planteado la posibilidad de que el lenguaje periodístico, en general, se esté convirtiendo en una "lengua especial", es decir, en "un islote en el seno de la lengua general al cual caracterizan rasgos no compartidos por la comunidad hablante, y que son sólo distintivos de un grupo, en este caso el de los periodistas, quienes los adoptan como marcas diferenciales de su oficio". ${ }^{104}$ El lenguaje del periodismo es una lengua especial en la medida en que tiende a ser un registro para iniciados (y, en opinión de Lázaro Carreter, no lo es plenamente porque "la fijeza y hasta inflexibilidad de algunos de sus rasgos alterna con las ocurrencias más personales de quien escribe, y que chocan frontalmente con los hábitos de los lectores"). ${ }^{105}$ Ya se le considere sociolecto, estilo, registro, lengua especial o lenguaje sectorial, el modo de expresarse de los periodistas obliga al lector a estar habituado a una cierta retórica inexistente en discursos de otro tipo.

En ningún otro sitio del discurso periodístico esto es más notorio que en los titulares: si bien la configuración lingüística de muchos de ellos difiere en poco o nada de la de otros enunciados de la lengua, hay algunos encabezados

\footnotetext{
102 "The modern headline [...,] it speaks a language of its own" (Garst y Bernstein 1940: 141).

${ }^{103}$ Alarcos 1977: 130.

${ }^{104}$ Lázaro Carreter 1990: 25. Cf. Garst y Bernstein 1940: 141.

${ }^{105}$ Lázaro Carreter 1990: 31.
} 
que se separan "con nitidez de las manifestaciones lingüísticas habituales". 106 En esta sección propongo, con carácter de exploración general, un inventario breve y sin duda de ningún modo exhaustivo de los rasgos formales de codificación lingüística más característicos de este tipo de textos, algunos de los cuales son privativos de él.

Antes de ello, conviene recordar que el discurso periodístico destaca, entre otras razones, por su capacidad para acoger en su seno rasgos de otros registros lingüísticos, razón por la cual ha recibido el singular apelativo de "nido de lenguajes". ${ }^{107}$ De acuerdo con Lázaro Carreter, ${ }^{108}$ el discurso informativo modula entre registros literarios, administrativos y vulgares. Para él, este tipo de discurso, por una parte, lleva al idioma hasta el límite de un modo de expresión literario de aliento épico o belicista; por otra, adopta un estilo burocrático, administrativo, en el que se aprecian notas de ampulosidad y abstracción, además de abundantes rodeos gramaticales y extranjerismos, y, por otra más, presenta una invasión creciente del lenguaje de base oral en un intento de aproximarse a núcleos populares masivos.

Al igual que el resto del discurso periodístico, los titulares asimilan —en atención, normalmente, a las funciones que hemos descrito- rasgos de la lengua literaria, administrativa, técnico-científica y popular. Mucho se ha escrito, sobre todo desde perspectivas de intención normativa o de políticas linguiísticas, sobre la conveniencia o no de adoptar estos usos en el habla difundida por los medios de comunicación, habida cuenta, evidentemente, de su capacidad socializadora y educativa. Más aún se han criticado los distintos lapsus que a menudo se observan en los medios informativos. ${ }^{109}$ De ningún modo son escasos, por cierto, los comentarios de abierto repudio hacia la forma en que se redactan los titulares: "A veces, la manía de la 'cabeza' o ‘encabezamiento' traduce un modo de tra EL DISCURSO AJENO EN LOS TITULARES PERIODÍSTICOS

\footnotetext{
${ }^{106}$ Alarcos 1977: 128-129.

${ }^{107}$ Martínez Hernando 1990: 44.

${ }^{108}$ Lázaro Carreter 1977.

${ }^{109}$ Cf. Fontanillo y Riesco 1990, Hernández R. 1990, Romero Gualda 1994, Tejada CondePelayo 2005, entre muchísimos otros.
} 
bajar con los pies", ${ }^{110}$ dice Martín Vivaldi, por ejemplo. ${ }^{111}$

El inventario que presento a continuación no se detiene, sin embargo, en estos aspectos. Me referiré solamente a las particularidades formales más frecuentes o más características de este tipo de discurso, atendiendo, cuando proceda, al factor diatópico. Identifico cuatro rasgos constantes y cuatro variables. Los primeros se hallan de manera relativamente homogénea por todo el corpus, si bien algunas de sus variantes presentan, como veremos, ciertos condicionamientos. Los rasgos variables muestran una distribución menos regular.

\subsubsection{Rasgos constantes}

\subsubsection{Bimembración expresiva}

Debido a que los encabezados son textos producidos en situaciones enunciativas que llevan al límite la tensión entre economía e informatividad, este tipo de discurso ha desarrollado estructuras difícilmente empleadas en otras situaciones de comunicación. Ya Alarcos ${ }^{112}$ señalaba la "bimembración expresiva" como un rasgo característico de los titulares periodísticos. Según este autor, con dicho recurso el tema y el rema - es decir, la información consabida y la información nueva- se separan "como si dijésemos enfrentándolos", ${ }^{113}$ o bien se desgaja por marginación o por relieve alguno de los elementos constitutivos de la secuencia lingüística completa.

\footnotetext{
${ }^{110}$ Martín Vivaldi 1998: 224.

${ }^{111}$ Ante lo cual algunos periodistas se justifican aduciendo presiones de tiempo: "En esa hora última y apresurada de la titulación, [...] no es fácil ni oportuno que los hombres que titulan puedan detenerse en un análisis de su labor" (Vigil Vázquez 1966: 204).

${ }^{112}$ Alarcos 1977: 146.

${ }^{113}$ Alarcos 1977: 144.
} 


\subsection{Bimembración del tipo 1: marco de referencia}

En los ejemplos de la serie (1) se aísla un segmento locativo o tematizador por medio de la escisión marcada gráficamente por los dos puntos. En estructuras de esta clase, producto de lo que denomino bimembración del tipo 1, se presenta, marginado y en posición inicial, un encuadre locativo o tematizador: es locativo en los ejemplos (1a) y (1b), y tematizador en (1c) y (1d). La economía lingüística es relativamente escasa en (1a) y (1b), pues solo se prescinde de la modesta preposición en. En (1c) y (1d), por el contrario, se economizan más unidades: estamos ante lo que en la terminología inglesa se conoce como hanging topic — traducido como "tema vinculante" por Zubizarreta- ${ }^{114}$ procedimiento que tiene por objeto introducir un nuevo tema en el discurso y que suele incorporar locuciones como en cuanto a o con respecto $a$. De acuerdo con la terminología adoptada por Gutiérrez Ordóñez, ${ }^{115}$ podemos decir que se trata de "marcos de referencia" o, simplemente, "tópicos".

a. México: encuentran 5 cadáveres con tiro de gracia [HOY $\quad 0 / 01 / 10$ : 16B]

b. HAITÍ: VAN 70 MIL ENTERRADOS [UNI 18/01/10: A1]

c. Aerolíneas: 21 de sus 73 aviones no vuelan por falta de mantenimiento [CLA 19/01/10: 8]

d. Metro: Expertos sugieren construir juntas líneas 6 y 3 [MER 20/01/10: A1]

Registro casos en periódicos de todos los países considerados. En los diarios argentinos y chilenos (particularmente Clarín y El Mercurio) se observa con mayor frecuencia que en los demás. Está presente este tipo de bimembración incluso en las planas de publicaciones cuyos libros de estilo prescriben evitarla, como El País de Madrid: "Los dos puntos se utilizarán [en los titulares] sólo cuando después de un nombre propio siga una frase

\footnotetext{
${ }^{114}$ Zubizarreta 1999: 4220.

${ }^{115}$ Gutiérrez Ordóñez 2000.
} 
entrecomillada, una frase pronunciada por esa persona" ${ }^{\# 16}$ (el complejo testimonio [8a], que veremos más adelante, procede de este periódico). ${ }^{117}$

\subsection{Bimembración del tipo 2: discurso directo}

Algo más abundante, la bimembración del tipo 2 produce el aislamiento del sujeto léxico de un verbo de habla elidido. Del otro lado de la marca gráfica, que por lo general es también dos puntos, se ubica la declaración reproducida (a menudo no entrecomillada). Partición esta "en dos segmentos de la secuencia [que] no se daría en otras situaciones de habla", ${ }^{118}$ se trata de una variedad del discurso directo propia de los titulares periodísticos a cuya descripción detallada está dedicada, por ello, una parte del capítulo siguiente. Baste saber, de momento, que se encuentra en todos los periódicos considerados en esta investigación, aunque, eso sí, con órdenes de constituyentes no siempre generalizados. Los titulares de la serie (2) presentan en posición inicial el sujeto léxico del verbo de habla; en los de la serie (3), en cambio, este se ubica en posición final. Como veremos más adelante, no se presentan casos de posposición de sujeto de verbo de habla en la prensa española.

a. John Travolta: “Tengo el corazón roto" [ELP 06/01/09: 36]

b. Rodrigo Arias: 'Desmentiré ese montón de sandeces' [LAN 21/01/10: 5A]

c. Gubaidulina: «No podemos exigir que toda la gente nos comprenda» [ АВС 09/01/09: 43]

d. Acosta: "Espero ganar mucha experiencia" [ELN 21/01/10: B5]

a. "Hacer arte no es fumarse un churro": Héctor Falcón [UNI 24/01/10: K20]

b. 'Por ahora, no hay más ayuda en especie': Cruz Roja [TPO 21/01/10: 1-5]

\footnotetext{
${ }^{116}$ El País 2003: 55. Cf. El Periódico 1989: 16.

117 Autores como Pou Amérigo (2004: 255) censuran más abiertamente este tipo de construcciones, pero también sin justificaciones explícitas.

${ }^{118}$ Alarcos 1977: 142.
} 
c. "Entienda, el país ya no es de un solo hombre": López Obrador [JOR 26/02/05: 1]

d. Blanco no gana solo: Del Olmo [OPI 19/01/10: 3C]

\subsection{Bimembración del tipo 3: oración atributiva no copulativa}

La bimembración del tipo 3 relaciona, sin verbo copulativo, el sujeto léxico y el atributo. El resultado es, claro está, una oración atributiva no copulativa, construcción cuya productividad en los titulares ha sido frecuentemente aludida. ${ }^{119}$ Por cuanto estas expresiones se forman con grupos nominales que se combinan básicamente con los verbos ser y estar, algunos autores ${ }^{120}$ entienden que se trata de elipsis verbales. ${ }^{121}$ La configuración bimembre destaca diferencialmente los dos componentes de la estructura informativa (tema y rema), por lo general mediante la marca ortográfica de la coma (y su correlativa pausa): ${ }^{122}$

(4) a. Canadá, mercado ideal para orgánicos [COM 19/01/10: B6]

b Mediterráneo y África, destino preferente de las futuras misiones [MUN 07/01/09: 12]

c. Periodista de tevé, víctima de ladrones [CLA 21/01/10: 42]

d. Obama, frustrado por la lentitud de los cambios [ТРО 8/01/10: 16]

e. "Ganar dos 'oscars', imposible" [ELP 20/01/10: 34]

f. Obsoleto, reglamento de obras en Colima [UNI 22/01/10: A17]

La mayoría de los titulares de este tipo presenta el orden "sujeto - predicado", como se observa en los casos (4a), (4b), (4c), (4d) y (4e). Menos frecuente, la pauta inversa ("predicado - sujeto") está ejemplificada por (4f). Esta tendencia a las construcciones absolutas independientes alcanza incluso a segmentos entrecomillados que se exhiben como reproducciones literales, a

\footnotetext{
${ }^{119}$ Por ejemplo, RAE y AALE 2009: $\$ 38.13$ d.

${ }^{120}$ Por ejemplo, Garst y Bernstein 1940: 145, Gómez Mompart 1982: 110-111, López Hidalgo 2009: 115.

${ }^{121}$ Es bien sabido que, para gramáticos como Roca Pons, estos enunciados no comportan elipsis, pues, según se dice, "la presencia del verbo daría otro carácter a la expresión" (Roca Pons 1974: 299).

${ }^{122}$ Libros de estilo hay, como el de $E l$ Mundo, que exigen el uso obligatorio de la coma en titulares de esta clase (El Mundo 1996: 69).
} 
pesar de que en realidad no lo sean, como en el titular (4f), tal y como demuestra su cotejo con el texto que encabeza (como veremos más adelante, la literalidad del discurso directo es algo muy relativo en los titulares).

\subsubsection{Elipsis}

Como resultado del principio de economía lingüística, que, como hemos dicho, adquiere en el discurso de los titulares proporciones extremas, los mecanismos de elipsis son, lógicamente, soluciones habituales en la codificación de los encabezados. Identifico cuatro tipos de elipsis habituales en este tipo de enunciados.

Antes de hablar de cada una de ellas, conviene advertir, sin embargo, que no son pocos los autores que censuran esta tendencia a elidir segmentos lingüísticos. Se la ha tildado de "antiestético laconismo", ${ }^{123}$ de "esquematismo inhumano, sin gracia y sin belleza" ${ }^{124}$ y hasta de "vicio norteamericano". ${ }^{125}$ No son inhabituales, de hecho, las críticas que en unos países se hacen sobre las particularidades morfosintácticas de los titulares de la prensa de otros países, ${ }^{126}$ y se opina negativamente atribuyendo a ciertos usos, como algunas elipsis, orígenes estadounidenses ${ }^{127}$ como consecuencia de un "subdesarrollo periodístico" y un "imperialismo sociocultural". ${ }^{228}$

Sin entrar en cuestiones estilísticas o de corrección lingüística, siempre relativas, es preciso aclarar que, si bien es cierto que en los titulares del

\footnotetext{
${ }^{123}$ Martín Vivaldi 1998: 234.

${ }^{124}$ Martín Vivaldi 2000: 376. Cf., por ejemplo, Alarcos 1977: 146, Romero Gualda 1994: 27, Grijelmo 2003: 468, Rojas 2003: 75, Grillo 2004: 74.

${ }^{125}$ Martín Vivaldi 1998: 219.

${ }^{126}$ Por ejemplo, Gaillard 1972: 111, Gómez Mompart 1982: 46. Cf. Muñiz Chacón 1990: 216, Hernando Cuadrado 2000: 24.

${ }^{127}$ Cf. Casasús 1988: 124, entre muchos otros.

${ }^{128}$ Por ejemplo, Gómez Mompart 1982: 59, Fontcuberta 1993: 121, López Hidalgo 2009: 63.
} 
periodismo estadounidense son muy frecuentes las elipsis - pues a menudo se piensa que con la omisión de palabras no esenciales se tiende a "dar al encabezado una velocidad telegráfica y por tanto a hacerlo más vívido"-,${ }^{129}$ también es verdad que, desde su no tan lejano origen, los titulares están en todo el mundo, como ya hemos apuntado, estrechamente ligados a los que se publican en Estados Unidos. Luego entonces, por poca reflexión que se haga, habrá de concluirse que es totalmente esperable que en los encabezados del ámbito hispánico se eche mano también de estos recursos.

No obstante las numerosas críticas —que apuntan normalmente a cuestiones de incorrección o incomprensión-, y aun las claras proscripciones en libros de estilo, ${ }^{130}$ los distintos tipos de elipsis que mencionaré en seguida son muy vitales en las planas de los diarios en español. Es evidente que, si de verdad fueran imposibles de decodificar, difícilmente seguirían en uso. Con frecuencia llamados peyorativamente "telegráficos", ${ }^{131}$ los titulares elípticos son comprensibles, dice Gómez Mompart, "de igual modo que todo el mundo entiende un telegrama". ${ }^{132}$

\subsection{Elipsis del tipo 1: verbos de habla}

A la supresión de verbos que acompaña a la bimembración expresiva del tipo 2 (verbos de habla en discurso directo) - que denomino arbitrariamente elipsis del tipo 1 -, se suman otras tres formas de elipsis que, por su insistente presencia en los titulares, se convierten asimismo en un rasgo de este tipo de discurso: las elipsis de artículos, de nexos y de sustantivos. Retomo aquí

\footnotetext{
129 " $[\ldots]$ the omision of non-essential words, chiefly articles. This practice has a tendency to give the headline telegraphic speed, and hence to make it more vivid" (Garst y Bernstein 1940: 97).

${ }^{130}$ Por ejemplo, Abc 2001: 165, El País 2003: 51, El Universal 2004: 32.

131 Gaillard 1972: 111, Muñiz Chacón 1990: 216, López Hidalgo 2009: 46, entre otros.

${ }^{132}$ Gómez Mompart 1982: 110.
} 
nuevamente algunos ejemplos de elipsis de verbo de habla en discurso directo, bien entendido que volveré al tema en el capítulo correspondiente:

a. Rodrigo Arias: 'Desmentiré ese montón de sandeces' [LAN 21/01/10: 5A]

b. "Hacer arte no es fumarse un churro": Héctor Falcón [UNI 24/01/10: K20]

\subsection{Elipsis del tipo 2: determinantes}

Llamo elipsis del tipo 2 a la supresión de determinantes. Las características tan específicas de la situación de textualización de los encabezados favorece, como se sabe, la omisión de artículos, posesivos y demostrativos, por lo que no es infrecuente el uso de grupos nominales escuetos en los títulos de las noticias. Parece que esta elección morfostntáctica se ha convertido en índice de situación para los titulares, hasta el punto de presentarse, a veces, incluso con sustantivos contables en singular.

(6) a. Hampones golpean a esposa de médico amenazado [LAN 20/01/10: $12 \mathrm{~A}$ ]

b. La Paz deja entrever inquietud or futuro de agenda de diálogo que incluye tema marítimo [MER 19/01/10: C2]

c. Dan de alta a niño herido por pedrada [COM 20/01/10: A10]

d. Inseguridad agrava crisis en Haití [TРО 18/01/10: 1-2]

e. Muere fundador de Taco Bell [UNI 19/01/10: B7]

f. Conductor de Metrolink fue 'culpable del choque' [OPI 22/01/10: 4A]

g. Oposición exige plan de seguridad [ELN 23/01/10: A4]

h. Washington incrementa ayuda financiera a oposición venezolana [GMA 25/01/07: 3]

i. Austríaco busca romper barrera del sonido con su cuerpo [HOY 23/01/10: 9B]

Las Academias entienden que, en este registro escrito, la ausencia de artículos "se interpreta como marca de inespecificidad", ${ }^{133}$ de modo que, agregan, un

${ }^{133}$ RAE y AALE 2009: $§ 15.12 \mathrm{f}$. 
enunciado como Hombre armado robó almacén significa aproximadamente 'Cierto hombre armado robó un almacén'. Es necesario aclarar, sin embargo, que no siempre resulta pertinente esta interpretación, como a todas luces ocurre, por ejemplo, con esposa, futuro y barrera del sonido en los testimonios (6a), (6b) y (6i), respectivamente.

Fuera de Hispanoamérica suele decirse que las elisiones de determinantes constituyen un fenómeno exclusivo de los titulares del "periodismo americano". ${ }^{134}$ Es habitual leer descripciones que presentan este fenómeno como "un rasgo que distingue" 135 a los periódicos hispanoamericanos de los españoles, pues, según se acostumbra decir, los determinantes -y en particular los artículos - están "siempre presentes en la prensa española y solo en algunos casos en la prensa hispanoamericana". ${ }^{136}$

Los materiales de mi corpus, sin embargo, indican que, si bien es cierto que la elipsis del tipo 2 es más abundante en las planas de algunos diarios hispanoamericanos que en los españoles, en realidad en España es hoy en día un procedimiento habitual, pero — eso sí- de productividad más restringida y condicionada. Mientras que en los encabezados de buena parte de Hispanoamérica —ejemplificados en la serie (6) — los determinantes se omiten en cualquier contexto, ${ }^{137}$ en España este fenómeno tiene lugar, de acuerdo con mis materiales, sobre todo ante sustantivos colectivos o nombres de instituciones, y particularmente si se hallan en función de núcleo del sujeto cuando este argumento se sitúa en posición preverbal, como se comprueba con la serie (7), integrada totalmente por ejemplos de la prensa española:

(7) a. Militares recuerdan a Chacón que ellos pueden ser arrestados por vestir de forma inadecuada [MUN 08/01/09: 12]

\footnotetext{
${ }^{134}$ Alarcos 1977: 146, Martín Vivaldi 2000: 376, Grijelmo 2003: 468, entre otros. Cf. Muñiz Chacón 1990: 216, Hernando Cuadrado 2000: 24, RAE y AALE 2009: §15.12g, López Hidalgo 2009: 46.

${ }^{135}$ Romero Gualda 1991: 545.

${ }^{136}$ Gómez Sánchez 2008: 54. Las cursivas son mías.

${ }^{137}$ Pero más en posición inicial.
} 
b. Comandos israelíes juntan a los varones, los atan y desnudan [MUN 06/01/09: 21]

c. PP y PSOE buscan la fórmula para ampliar a toda la vida laboral el cálculo de la pensión [ABC 05/01/09: 28]

d. PNV, PSE y 'abertzales' tachan de político el juicio a Ibarretxe y López [ELP 08/01/09: 12]

e. PNV y EA se ponen por fin de acuerdo para echar a ANV de Azpeitia [АВC 06/01/09: 19]

f. Los empleados de Lloyds aceptan educir plantilla un 30\% [ELP 19/01/10: 22]

Queda demostrada, pues, la inexactitud del supuesto "empleo completo"138 de determinantes en los titulares de la prensa española. ${ }^{139}$ Más o menos frecuente según el país y el diario, la elipsis de determinantes es, en realidad, un rasgo característico de los titulares periodísticos en todo el ámbito hispánico. Cabe precisar que, si hay un lugar donde es relativamente poco habitual este tipo de elipsis, es Argentina. De hecho, no recojo casos indiscutibles del periódico bonaerense Clarín, pero no por ello puede decirse que el fenómeno no se presente en ese país sudamericano, a juzgar por los datos del corpus de encabezados argentinos recopilado por Guntern Weibel. ${ }^{140}$

Sugieren las Academias que la posición preverbal de un grupo nominal sin determinante puede verse favorecida "cuando toda la información que transmite la oración es remática [...], ya que en tales casos no existe información discursiva previa acerca de los participantes en la predicación". ${ }^{141}$ También inciden, claro está, las tradiciones periodísticas y normas internas de redacción: el libro de estilo del diario madrileño $A b c$, por

\footnotetext{
${ }^{138}$ Rebollo Torío 2008: 165.

${ }^{139}$ Como puede advertirse en la serie (6) y muchos otros testimonios recogidos en este trabajo, tampoco es exacta la impresión de Martín Vivaldi en cuanto al supuesto uso exclusivo de sustantivos y verbos declarativos para redactar encabezados en Hispanoamérica: "Hoy, en el periodismo americano, por economía de espacio, se tiende a la titulación estilo telegrama. Sólo se utilizan los sustantivos y verbos declarativos" (Martín Vivaldi 2000: 376).

${ }^{140}$ Guntern Weibel 2000.

${ }^{141}$ RAE y AALE 2009: §15.12b.
} 
ejemplo, ordena a sus redactores procurar que ni los títulos ni los sumarios "comiencen por artículo". 142

\subsection{Elipsis del tipo 3: nexos}

Muy frecuente en los diarios del mundo hispánico es la omisión de nexos, a la que nos referiremos en lo sucesivo como elipsis del tipo 3. No se trata, desde luego, de un fenómeno exclusivo de los titulares ni del registro periodístico de la lengua, pero, en opinión de Casado Velarde, ${ }^{143}$ probablemente se ha extendido desde este ámbito a otras esferas de la lengua. En los encabezados adquiere, en todo caso, proporciones mayores.

(8) a. Penélope Cruz / Kate Winslet: diamantes, fuera [ELP 18/02/09: 37]

b. PRI-PVEM van por un distrito [UNI 08/01/09: A13]

En la serie (8) reproduzco ejemplos de un primer grupo: en estos casos se omite una conjunción. La relación de enlace se marca por medio de algún índice gráfico - ya guion (-), ya barra (/) — que enfrenta dos elementos nominales. En ambos ejemplos, estos signos ortográficos auxiliares sustituyen a la conjunción copulativa $y$. Puesto que, si es posible hablar de economía lingüística, esta resulta mínima, no parece excesivamente aventurado suponer que tales construcciones encuentran su motivación en una tendencia a establecer relaciones de contraposición mediante signos ortográficos sin correlato articulatorio. De hecho, puede decirse que, en casos como (8a), el primer segmento que resulta de una bimembración del tipo 1 está también expresivamente bimembrado: ambos nombres aparecen enfrentados por medio de una barra. En los dos titulares de la serie se establece una relación paratáctica entre los elementos contrapuestos por medio del guion o la barra

\footnotetext{
${ }^{142}$ Abc 2001: 165.

${ }^{143}$ Casado Velarde 1986: 224.
} 
(relación claramente evidenciada en el segundo ejemplo por la concordancia del verbo). En (8b) se presentan, asimismo, casos de elipsis del tipo 2.

Identifico un segundo grupo de elipsis del tipo 3: aquí dos o más elementos enfrentados mediante guiones funcionan como el complemento de un sustantivo, sin la intermediación de los nexos prepositivos que estarían presentes en otras situaciones enunciativas. En los casos que ahora nos ocupan, se conserva la relación hipotáctica a pesar de la ausencia de un nexo prepositivo. El resultado es una construcción apositiva especificativa, esquema cuya productividad ya identificó Lapesa y donde "todo se concita para que el sustantivo, sin adición de sufijos y sin transpositor, asuma con frecuencia funciones de adjetivo". ${ }^{144}$ Reproduzco algunos ejemplos en la serie (9):
a. Prevén diálogo Obama-Hamas [REF 9/01/09: INT 1]
b. Comisión verá choque Caja-cafetaleros [LAN 19/01/10: 18A]
c. Matsui aboga por serie EEUU-Japón [HOY 21/01/10: 5B]
d. Aguda tensión Chávez-Uribe [OPI 18/01/10: 11A]
e. Valcárcel advierte que se rebelará si se cercena el trasvase TajoSegura [ELP 20/01/10: 14]

f. Dos muertos en celebraciones del juego Caracas-Magallanes [ELN 24/01/10: C8]

g. Auth apunta a la responsabilidad del comando y bloque PD-DC en derrota de Eduardo Frei [MER 21/01/10: A1]

h. En 3 citas se pactó alianza EIn-Farc [тРО 24/01/10: 1-2]

i. Alianza PT-PRD-PAN, "un engendro maligno": PRI [UNI 23/01/10: A16]

Martínez de Sousa habla en estos casos de guion prepositivo porque considera que por lo general tal signo sustituye a una preposición y "raramente a una conjunción". ${ }^{145}$ En todos los ejemplos de la serie, sin embargo, parece que, al igual que en el grupo anterior, este signo sustituye a una conjunción copulativa (diálogo Obama-Hamas < diálogo entre Obama y Hamas). Si bien la dualidad es el patrón dominante — expresada a menudo por los sustantivos

\footnotetext{
${ }^{144}$ Lapesa 1977: 222.

${ }^{145}$ Martínez de Sousa 2004: 436.
} 
subordinantes: diálogo, choque, tensión, juego_, en ocasiones se ponen en relación más de dos términos, como sucede en el testimonio (9i). ${ }^{146}$

El último grupo de elipsis del tipo 3 corresponde a los casos de omisión de preposiciones y conjunciones sin la presencia de signos ortográficos auxiliares. Es la que más críticas ha suscitado y, acaso por ello, la menos usual. De todos los periódicos considerados en esta investigación, el dominicano Hoy es el que presenta estas elipsis de modo más generalizado:

(10) a. Foro sugiere pacto superar el deficiente servicio electricidad [HOY 20/01/10: 12A]

b. Estrella acusa autoridades complicidad narco [HOY 18/01/10: 10A]

c. Presidente Senado Haití herido sismo estable tras cirugía [HOY 18/01/10: 4A]

d. Dice espera aprobación ley partidos [HOY 26/01/10: 5A]

Los enunciados anteriores podrían parafrasearse así: (Cierto) foro sugiere (un) pacto PARA superar (el) deficiente servicio DE electricidad; (Una) estrella acusa A (las) autoridades DE complicidad CON (el) narco; (El) presidente DE(l) Senado DE Haití, herido EN (el) sismo, estable tras (una) cirugía; Dice QUE espera (la) aprobación DE (la) ley DE partidos. Este tipo de formulaciones no parecen ser más que respuestas a la necesidad de condensar la información en un espacio muy limitado, pero llevadas a casos límite. En cuanto a las elipsis de preposiciones, es probable que en algunos casos se vean favorecidas por las actitudes de repudio, frecuentes en el gremio periodístico, hacia este tipo de nexos cuando se sitúan al final de un renglón en los encabezados. ${ }^{147}$ Dedico una parte del capítulo sobre discurso indirecto al estudio de los titulares que, como el ejemplo (10d), presentan elipsis de conjunción completiva.

\footnotetext{
${ }^{146}$ Después de todo esto, no dejan de sorprender afirmaciones como la de Pou Amérigo, para quien "los guiones (-) no tienen apenas uso en los titulares de prensa, pero son necesarios en la publicación de resultados deportivos o electorales" (Pou Amérigo, 2004: 256).

${ }^{147}$ Cf. Neal 1933: 113, Garst y Bernstein 1940: 129, Fontcuberta 1993: 128.
} 


\subsection{Elipsis del tipo 4: sustantivos}

La economía lingüística de los encabezados llega incluso a la omisión del sustantivo subordinante -elipsis del tipo 4-, como se advierte en los ejemplos de (11). De ningún modo exclusivo de los titulares, pero sí muy frecuente en ellos, este procedimiento obliga al lector a restituir, mediante un proceso inferencial, el núcleo de un sintagma nominal. En los titulares (11a), (11b), (11e), (11f) y (11g) se han suprimido los sustantivos centrales, Tribunal, partido o encuentro, proyecto y conflicto, respectivamente. En (11c) y (11d), se trata de elecciones. En (11e) y (11f) hay también elipsis del tipo 3, al igual que en (11g), donde además se advierte una elipsis del tipo 2 y bimembraciones de los tipos 1 y 3 .

a. Las nucleares salvan a Francia [ $\mathrm{ABC}$ 08/01/09: 23]

b. El Supremo de EE UU permite financiar sin límite las campañas [ELP 22/01/10: 11]

c. Rajoy nombra a Mayor Oreja candidato a las europeas tras el ascenso en los sondeos de Díez [MUN 05/01/09: 7]

d. Mesa de la Unidad designó comisión para as primarias [ELN 19/01/10: A2]

e. El Barça-Atlético, el miércoles a las 22.00 [ELP 10/01/09: 39]

f. Cusco y Arequipa retoman diálogo sobre Majes-Sihuas [COM 23/01/10: A21]

g. Televisa-Univisión: en un mes, la decisión del juez [MIL 08/01/09: 20]

Estas omisiones también son repudiadas con cierta frecuencia. El libro de estilo del diario barcelonés La Vanguardia, por ejemplo, las censura abiertamente: "En la redacción de títulos y textos periodísticos debe erradicarse el uso de elipsis en los nombres propios o en la denominación de personas u organismos". ${ }^{148}$ Esta opinión, claro está, no es unánime en el gremio periodístico. Grijelmo, quien fue redactor de El País durante años, de hecho recomienda a los periodistas neófitos acudir a este procedimiento para

${ }^{148}$ La Vanguardia 1986: 15. 
disminuir la extensión de los encabezados: "Se puede tomar una palabra del grupo y usarla con valor equivalente al total". Y añade una anécdota: “Cuando en España se empezó a escribir 'el Constitucional' muchos lectores criticaban una expresión tan extraña, y ahora ya se ha acostumbrado todo el mundo". 149

\subsubsection{Estructuras nominales}

Aunque a veces los periodistas consideran impropios los titulares sin verbo, ${ }^{150}$ en realidad los encabezados unimembres, y en particular los que están constituidos por un sintagma nominal, son bastante "frecuentes en la prensa de cualquier país hispanohablante". ${ }^{151}$ Las secuencias de este tipo, ejemplificadas en la serie (12), representan la más clara expresión del valor de rótulo que tienen los encabezados, pues se convierten en un nombre identificador del contenido de la noticia. Llamados "títulos estáticos" 152 por Fontcuberta, "los titulares de prensa formados por grupos nominales se interpretan existencialmente", ${ }^{153}$ observan las Academias.

(12) a. Juicio histórico contra Juan Ibarretxe [MIL 8/01/09: 37]

b. Derrame de petróleo en Texas [LAN 24/01/10: 26A]

c. Alerta epidemiológica por dengue [ELN 22/01/10: C9]

d. Sismo de 4,1 grados [COM 18/01/10: A17]

e. Dificultades en el Senado [CLA 19/01/10: 6]

f. Nuevo tratamiento eficaz contra la esclerosis [HOY 22/01/10: 7C]

g. Demanda contra intendenta por daños [MER 21/01/10: C8]

h. Una semana de tormentas [OPI 18/01/10: 1A]

j. Restricción a vuelos de mineras [TРО 18/01/10: 1-9]

k. Recepción de los candidatos [ABC 11/01/09: 8]

\footnotetext{
${ }^{149}$ Grijelmo 2003: 489.

${ }^{150} C f$. Martín Vivaldi 1998: 217, Abc 2001: 165, Armentia y Caminos 2003: 80, Pou Amérigo, 2004: 253-254, por ejemplo.

${ }^{151}$ Romero Gualda 1991: 547. Según entiende esta autora, los titulares nominales son frecuentes porque "parece que el verbo no da la imagen de inmediatez que se consigue con las secuencias nominales" (Ibid.).

${ }^{152}$ Fontcuberta 1993: 124.

${ }^{153}$ RAE y AALE 2009: $§ 38.13 f$.
} 
Por todos conocida es la tendencia nominalizadora del discurso periodístico: Steel, por ejemplo, apunta con razón que, en este, "el grupo nominal adquiere una relevancia y una extensión mayor que en otros estilos de lengua”. ${ }^{154}$ En los titulares, el principio de economía lingüística, aunado a otras motivaciones, ocasiona que muchos procesos, normalmente expresados con verbos, se reformulen como sustantivos, con lo que suele perderse información argumental, circunstancial, temporal, modal y aspectual. Así, las unidades que en la oración completa hubieran cumplido funciones argumentales —es decir, adyacentes del verbo - pasan a ser determinantes del sustantivo y, por consiguiente, fácilmente eliminables. Por ejemplo, el titular (12k) expresa que los candidatos han sido recibidos, pero no por quién. ${ }^{155}$ Son también nominalizaciones deverbales de acción los sustantivos derrame, tratamiento, demanda y restricción en (12 b), (12f), (12g) y (12j), respectivamente. Volveré a este tipo de encabezados en los capítulos sobre discurso indirecto y discurso narrado.

\subsubsection{Presente histórico}

La inmensa mayoría de titulares con verbo explícito se formula en presente de indicativo, a pesar de que normalmente los acontecimientos noticiosos son sucesos pasados. Esta práctica — “tradición periodística""156 para López Hidalgo y "dogma estilístico"157 para Francescutti- es hoy, asegura Bastenier, ${ }^{158}$ un recurso habitual en toda la prensa occidental. ${ }^{159}$ Transcribo algunos ejemplos hispánicos en la serie (13).

\footnotetext{
${ }^{154}$ Steel 1971: 13.

${ }^{155}$ Como bien observó Comrie (1976: 177-201), la estructura interna de los "nombres de acción" (action nominals) presenta distintos grados de correspondencia con las secuencias no derivadas.

${ }^{156}$ López Hidalgo 2009: 61.

${ }^{157}$ Francescutti 2009: 245.

${ }^{158}$ Bastenier 2001: 57.

${ }^{159}$ Martín Vivaldi (1998: 219) tilda este uso, nuevamente, de "criterio norteamericano".
} 
(13) a. Granjero mata a 51 vacas y se suicida [COM 24/01/10: B3]

b. Liberan a colombiano en Nigeria [ТРО 19/01/10: 1-7]

c. Autoriza juez subasta de vestido de Spears para Haití [UNI 24/01/10: K4]

d. Lluvias provocan caos en Tijuana [OPI 22/01/10: 6A]

e. La violan y su madre le abre el vientre [ $\mathrm{ABC}$ 07/01/09: 27]

f. Cristina anuncia la creación del Fondo [CLA 24/01/10: 6]

g. Un hombre mata a ocho personas en Virginia [ELP 21/01/10: 3]

h. Uribe elude responder los señalamientos de Chávez [ELN 19/01/10: A10]

i. Alemania pide arresto de exdictador argentino Videla [LAN 23/01/10: 23A]

j. Bolivianos armados cruzan la frontera y asaltan a empresa [MER 24/01/10: C16]

k. Mueren 2 soldados estadounidenses al estallar bomba [HOY 20/01/10: 16B]

Los tratadistas del periodismo suelen argüir que, de esta manera, los encabezados "dan la idea de que los hechos acaban de ocurrir"160 o bien nos los presentan "como algo que está ocurriendo, que no ha terminado de pasar". ${ }^{161}$ En la misma línea, Martín Vivaldi entiende que "este presente periodístico tiene el sentido de un pasado reciente", ${ }^{162}$ y Charaudeau afirma que el referir los procesos noticiosos en el marco del presente permite confundir el momento del suceso con el de la enunciación del encabezado, con lo que el acontecimiento desborda su propio marco temporal y entra a formar parte del marco temporal del titular, gracias a lo cual el suceso adquiere un valor más universal. ${ }^{163}$

Como advertían Garst y Bernstein hace muchos años, ${ }^{164}$ este uso no es, evidentemente, una invención de quienes redactan titulares, sino que está tomado del habla cotidiana. La expresión de sucesos o estados pasados por

\footnotetext{
${ }^{160}$ Rojas 2003: 85. Cf. Neal 1933: 112, Johnson y Harriss (1942) 1963: 288, El Mundo 1996: 69, Martín Vivaldi 1998: 219, Bastenier 2001: 55, Armentia y Caminos 2003: 80, Pou Amérigo 2004: 253-254, López Hidalgo 2009: 69.

${ }_{161}$ Gomis 1991: 27. Cf. Fontcuberta 1993: 126.

${ }^{162}$ Martín Vivaldi 1998: 219.

${ }^{163}$ Charaudeau 1983: 109.

${ }^{164}$ Garst y Bernstein 1940: 96.
} 
medio del presente de indicativo — conocida como presente histórico- es estudiada en casi todos los manuales de gramática y, del mismo modo que hacen Alarcos ${ }^{165}$ y Hurtado ${ }^{166}$ con respecto a la formulación de encabezados, suele explicarse o presentarse implícitamente como una neutralización en el sistema de oposiciones estructurales que contiene el sistema verbal español: por ser el miembro no marcado de todas las correlaciones en que participa —no tiene matiz modal, no significa lo futuro, no significa lo pasado-,${ }^{167}$ el presente de indicativo adquiere fácilmente, dicen, valores propios de las formas del pasado. Se ha demostrado ya, sin embargo, que dicho uso es una propiedad compartida por toda una serie de formas verbales, con sus contenidos temporales propios en la estructura del sistema, ${ }^{168}$ de modo que tal característica, por lo general atribuida en exclusividad al presente de indicativo, no parece ser en realidad la causa de su valor histórico. ${ }^{169}$ Puede decirse, con Porto Dapena ${ }^{170}$ o Moreno de Alba, ${ }^{171}$ que no se trata sino de una transposición o dislocación temporal que actualiza hechos pretéritos.

Alcoba Rueda ${ }^{172}$ describe este uso del presente en los titulares como un protiempo anafórico a causa de lo que él llama la carencia de deixis temporal, que exige, para la adecuada interpretación del texto, el establecimiento de una relación fórica con el texto contiguo, es decir, la nota informativa. Otros autores, como Gomis ${ }^{173}$ y Fontcuberta, ${ }^{174}$ aseguran, sin embargo, que el presente histórico contribuye a convertir los encabezados en un conjunto de lectura autónoma y, hasta cierto punto, independiente de los textos que encabezan.

\footnotetext{
165 Alarcos 1977: 147.

${ }^{166}$ Hurtado 2003: 38-39.

${ }^{167}$ Alarcos 1949: 67.

${ }^{168}$ Rojo y Veiga 1999: 2892, por ejemplo.

${ }^{169}$ Como es obvio, resolver dicho problema no es el propósito de esta investigación.

${ }^{170}$ Porto Dapena 1989: 50.

${ }^{171}$ Moreno de Alba 1985: 30 y 2003: 44-46.

172 Alcoba Rueda 1983.

173 Gomis 1991: 28.

${ }^{174}$ Fontcuberta 1993: 126.
} 
El presente histórico comporta efectos estilísticos de proximidad, viveza y fuerza dramática. ${ }^{175}$ Debido a ello se emplea en la narrativa oral para referir momentos climáticos de la historia relatada, tal como ha observado SilvaCorvalán. De acuerdo con ella, el presente de indicativo se utiliza en las cláusulas narrativas de los relatos orales como elemento evaluativo, es decir, como recurso mediante el cual "el narrador hace que la historia parezca interesante, divertida, entretenida o fuera de lo usual". ${ }^{176}$ En cuanto relatos condensados o extractados, los titulares —poseedores, según se ha demostrado, de un componente fundamental de carácter oral— ${ }^{177}$ parecen compartir este uso evaluativo del presente histórico: recuérdese que, con ellos, el periodismo busca impresionarnos y persuadirnos de que suceden cosas interesantes. $^{178}$

En este tipo de situaciones, el presente histórico se utiliza, pues, para indicar la relevancia de una cláusula narrativa llamando la atención sobre ella por medio de un efecto retórico de proximidad: "Al usar el Presente de Indicativo para describir hechos ocurridos en el pasado, el hablante los presenta como si los estuviera viendo en el momento de hablar", ${ }^{179}$ dice Silva-Corvalán y añade que la narrativa se torna así "más vívida y dramática". ${ }^{180}$ Lo mismo sucede con los encabezados, que ya son, per se, evaluaciones del contenido de las noticias.

Por último, conviene aclarar que, de igual manera que en algunas evaluaciones de relatos orales no se observa el presente histórico, también hay titulares con otras formas verbales. Por ejemplo, suele emplearse el futuro, como es natural, para aludir a los acontecimientos que se prevé o se anuncia

\footnotetext{
${ }^{175} C f$. Gili Gaya, 1967: §121, por ejemplo.

${ }^{176}$ Silva-Corvalán 2001: 204.

177 Guntern Weibel 2000, Lázaro Carreter 1977. Cf. Garst y Bernstein 1940: 145, Gomis 1991: 29.

${ }^{178}$ Gomis 1991: 27-34.

${ }^{179}$ Silva-Corvalán 2001: 204-205. Cf. Garst y Bernstein 1940: 97.

${ }^{180}$ Silva-Corvalán 2001: 205.
} 
que sucederán. En algunas ocasiones, más bien raras, también se publican — claro está- encabezados en pretérito perfecto, imperfecto o indefinido ${ }^{181}$ para referir acciones, estados o procesos pasados.

\subsubsection{Rasgos variables}

\subsubsection{Tercera persona impersonal}

Los periódicos hispanoamericanos presentan una indudable tendencia al uso de construcciones de interpretación impersonal en tercera persona del plural. El fenómeno es mucho menos frecuente en la prensa española, pero no es imposible de rastrear. Hay que insistir en que, en los diarios de Hispanoamérica, prácticamente no hay edición que no contenga una buena cantidad de ejemplos, ya sea que se conozca o no el agente del proceso. La diferencia con los rotativos españoles es tan notoria que, a juicio de Romero Gualda, este tipo de expresión impersonal "parece que puede convertirse en cliché para la prensa americana". ${ }^{182}$

En un trabajo sobre la impersonalidad en los medios de comunicación, Alcaide $^{183}$ demostró que casi todos los titulares españoles con tercera persona del plural y sin sujeto explícito pertenecen al universo de discurso de lo judicial o policial, y explica que esto se debe a que en ese campo tan estricto los papeles desempeñados por los posibles agentes están muy determinados, por lo que suelen sobreentenderse. Las referencias en los diarios hispanoamericanos son, por el contrario, mucho más amplias y no siempre resultan fáciles de determinar sin leer el texto contiguo:

a. Informan sobre la reforma migratoria [OPI 22/01/10: 3A]

\footnotetext{
${ }^{181}$ En la terminología de Bello, antepresente, copretérito o pretérito, respectivamente.

${ }^{182}$ Romero Gualda 1991: 544.

${ }^{183}$ Alcaide 2001: 302.
} 
b. Descubren conexión entre el trote y el nacimiento de nuevas neuronas [MER 20/01/10: A1]

c. Lanzan portal web de educación vial [СОМ 23/01/10: A15]

d. Anuncian torneo mayor de fútbol con varios equipos [HOY 21/01/10: 10B]

e. Entregan distinción a Cintio Vitier y Fina García Marruz [GMA 25/01/07: 2]

f. Recuperan Planta Centro con lentitud [ELN 24/01/10: A1]

g. Instalan diálogo para ayudar a economía [LAN 20/01/10: 24A]

h. Atrasan entrega de secundaria 43 [UNI 18/01/10: A13]

i. Duplican los refugios en las paradas de colectivos [CLA 19/01/10: 33]

j. Frenan ayuda no alimentaria [тРо 20/01/10: 1-6]

(15) Asesinan a tiros a un capo colombiano de la droga en el Doce de Octubre [АВС 09/01/09: 20]

En las oraciones de este tipo -no exclusivas de los encabezados, naturalmente - la tercera persona del plural adquiere un significado indefinido o indeterminado cuando alude bien sea a un sujeto sobreentendido o desconocido, como en (15), o bien a un sujeto cuya referencia no interesa expresar, como en los casos de (14). Los testimonios como (15), normalmente referidos a cuestiones policíacas o judiciales, se encuentran tanto en los periódicos hispanoamericanos como en los españoles. Los de la serie (14) son, en cambio, casi exclusivos de Hispanoamérica. La motivación a que obedecen estos últimos no siempre es fácil de determinar, pero se puede decir, de manera general, que la economía lingüística y las tradiciones periodísticas $^{184}$ pueden acompañarse de juicios que apuntan a información periodísticamente irrelevante o inconveniente desde el punto de vista ideológico, sobre todo si se considera que los titulares son las únicas secuencias leídas por la mayoría de los consumidores de diarios. El efecto en los lectores es aún más difícil de precisar, pero baste de momento la impresión que comparte Grijelmo: "Este truco confunde al lector

\footnotetext{
${ }^{184}$ Según suele decirse, la prensa hispanoamericana tiene, frente a la española, una marcada tendencia a la impersonalidad en la formulación de titulares ( $c f$., por ejemplo, Romero Gualda 1991, Rebollo Torío 2008: 174, Hurtado 2009: 194).
} 
precisamente porque, por lo general, sí se conoce quién protagoniza la noticia”. ${ }^{185}$ Volveré a este problema más adelante.

\subsubsection{Verbo inicial}

Es frecuente que, en los diarios hispanoamericanos, los titulares con verbo expreso presenten esta palabra en posición inicial. Como bien observaba Lapesa con respecto a los encabezados de prensa hispanoamericana, "mediante alteraciones en el orden normal de las palabras se intenta destacar los términos de mayor interés y orientar la atención de los lectores". ${ }^{186} \mathrm{Si}$ consideramos que, para los periodistas, el título "debe ser trabajado en forma que contenga en las primeras palabras lo esencial de la noticia"187 y que, como también suele decirse en el gremio, "la noticia es actividad, y el verbo representa acción", ${ }^{188}$ no resulta extraña la presencia de estructuras hiperbáticas como las de (16) en las planas de muchos diarios.

a. Desafía Cuevas a Ebrard [MIL 09/01/09: 1]

b. Estudia la UCLA violaciones a derechos laborales en LA [OPI 19/01/10: 8A]

c. Es Iztapalapa delegación que más ensucia sus calles [UNI 09/01/09: C1]

d. Muere hombre de dos puñaladas tras riña [LAN 22/01/10: 12A]

e. Retira aspiraciones candidato senador San Pedro Macorís [HOY 23/01/10: 6A]

f. Gana Femexfut juicio contra ex jugador Salvador Carmona [UNI 21/01/10: D3]

En opinión de Hurtado, con este orden de constituyentes "el titular adquiere un mayor dinamismo y expresividad". ${ }^{189}$ Además de esta posible motivación

\footnotetext{
${ }^{185}$ Grijelmo 2003: 467.

${ }^{186}$ Lapesa 1963: 200.

${ }^{187}$ SIP 1965: 86.

${ }^{188}$ Abc 2001: 165 .

${ }^{189}$ Hurtado 2003: 35.
} 
estilística $^{190}$ y de la pretensión de destacar la referencia a un proceso verbal, propicia este orden la tendencia hispanoamericana a formular encabezados en oraciones impersonales en tercera persona del plural, como sucede en los ejemplos de (14), que ya hemos visto.

Lapesa $^{191}$ y Martín Vivaldi ${ }^{192}$ consideran que se trata de una influencia estadounidense. En efecto, Neal ya aconsejaba en su manual de 1933 que se procurara situar el verbo lo antes posible en el título por cuanto, decía, el “verbo llama la atención por su acción”. ${ }^{193}$ Según este autor, si bien en aquella época algunos diarios estadounidenses no toleraban los titulares con verbo inicial, otros sí lo hacían, como el no poco prestigioso New York Times. ${ }^{194}$ Casi treinta años después, De Gregorio observaba en Italia: "De un estilo que llamaríamos clásico, en el cual las palabras ocupaban el lugar que se les asignaba conforme a una sintaxis normal, se ha pasado hoy (principalmente por influencia americana) a un estilo asintáctico, que se considera más eficaz, en el que el verbo (que expresa la acción y tiene, por tanto, un valor dinámico) o la palabra crucial de la frase preceden al resto". ${ }^{195}$

Según datos de Steel, ${ }^{196}$ este fenómeno oscila entre el $8 \%$ y el $20 \%$ en los titulares de periódicos de Argentina, Colombia, Chile, México, Paraguay, Perú y Venezuela. De acuerdo con Dubský y Heredia, ${ }^{197}$ la frecuencia asciende al $82 \%$ en la prensa cubana. Según mis materiales, si excluimos los casos de construcciones impersonales en tercera persona del plural, así como

\footnotetext{
${ }^{190}$ Dubský y Heredia concluyen de esta manera su trabajo sobre los titulares en la prensa cubana: "Podemos dar por comprobado que la preferencia dada a titulares discursivos con el verbo al principio se debe al deseo de mayor expresividad" (Dubský y Heredia, 1977: 37).

${ }^{191}$ Lapesa 1963: 200.

${ }^{192}$ Martín Vivaldi 1998: 231.

193 "A verb catches attention through its action" (Neal 1933: 107). Cf. Garst y Bernstein 1940: 125.

194 "Some papers refuse to permit a headline to start with a verb. Others, including such fine precedents as the New York Times, allow such a construction, though reluctantly" (Neal 1933: 109).

${ }^{195}$ De Gregorio (1960) 1966: 84.

${ }^{196}$ Steel 1971: 184.

${ }^{197}$ Dubský y Heredia 1977: 33. Cf. Romero Gualda 1991.
} 
los de sujeto tácito o extenso, el universo se restringe a los diarios de América del Norte, ${ }^{198}$ América Central y el Caribe insular. Como afirma Romero Gualda, "no se trata de un rasgo que no pueda rastrearse en la prensa española, pero en mucha menor proporción". 199

\subsubsection{Potencial citativo}

Relativamente usual en los titulares es el empleo del potencial citativo, es decir, las formas de condicional simple o compuesto ${ }^{200}$ empleadas para "dar a entender que se trata de aseveraciones ajenas, suposiciones cuya veracidad no se asegura o rumores no confirmados". ${ }^{201}$ A menudo censurado por su origen francés, ${ }^{202}$ este uso periodístico del condicional se observa en toda la prensa del ámbito hispánico, a excepción de los periódicos estadounidenses editados en lengua española, como La Opinión (Los Ángeles), El Nuevo Herald (Miami) y La Raza (Chicago). Dedico a él una sección completa en el capítulo sobre discurso indirecto.

a. Venezuela doblaría en reservas a A. Saudí [тро 24/01/10: 1-6]

b. Sería Ovelar [REF 11/01/09: CAN 8]

c. Sector construcción habría crecido 5,2\% [СОМ 19/01/10: B4]

d. Habría utilizado la CIA un Boeing 737 para transportar a presuntos terroristas [SOL 21/02/05: 15/A]

\footnotetext{
${ }^{198}$ El Universal de México reconoce, en su libro de estilo, que "comenzar con un verbo" es "el estilo general del diario" (El Universal 2004: 32). Según datos de Guízar (2007: 151), el verbo en posición inicial fue un patrón dominante en los titulares de este periódico durante todo el siglo XX.

${ }^{199}$ Romero Gualda 1991: 544.

${ }^{200}$ En la terminología de Bello, pospretérito o antepospretérito, respectivamente.

${ }^{201}$ Lapesa 1977: 88.

${ }^{202}$ Lázaro Carreter (1976) 1998: 386.
} 


\subsubsection{Criptónimos}

Un rasgo característico de la prensa mexicana es la abreviación de antropónimos por medio de siglas. Parece que, en general, los periódicos de ese país tienden más que los demás al uso de abreviaturas en los titulares. Ya observó Manuel Seco ${ }^{203}$ que es poco corriente en España la costumbre de referirse a una persona por medio de las iniciales de su nombre, pero Martínez de Sousa afirma que "en el lenguaje periodístico sí se han utilizado a veces los criptónimos". ${ }^{204}$ En mi corpus no registro ejemplos en titulares españoles ${ }^{205}$ ni de ningún otro país distinto de México. No es, por tanto, "una tendencia muy extendida", ${ }^{206}$ como afirma Rivadeneira Prada. Puedo decir que se trata de un recurso que la prensa mexicana emplea casi sistemáticamente para aludir a personajes muy conocidos, como el presidente de la República. ${ }^{207}$ En (18), los criptónimos $F C H, A M L O$ y $V F Q$ aluden a Felipe Calderón Hinojosa, Andrés Manuel López Obrador y Vicente Fox Quesada, respectivamente.

a. FCH urge a ubicar mexicanos en Haití [UNI 23/01/10: A8]

b. AMLO enviará a VFQ su libro para que no le sigan mintiendo [LAP 26/02/05: 35]

\footnotetext{
${ }^{203}$ Seco 1977: 193.

${ }^{204}$ Martínez de Sousa 1985: 156.

${ }^{205}$ No puede decirse, sin embargo, que no se acuda excepcionalmente a los criptónimos (tal como observaba Martínez de Sousa). En el siguiente ejemplo del diario madrileño Público —único testimonio en mis registros-, la forma $D S K$ alude a Dominique Strauss-Kahn, a la sazón director general del Fondo Monetario Internacional:
}

Los partidarios de DSK aún creen en el poder de su líder [PUB 19/05/11: 15]

Cabe aclarar que la abreviatura ZP, por Zapatero, no es propiamente un criptónimo, ya que no se trata de las iniciales de José Luis Rodríguez Zapatero (JLRZ). El origen de la abreviatura ZP es, como se sabe, el eslogan de una campaña electoral.

${ }^{206}$ Rivadeneira Prada 2007: 169.

207 Según Martínez de Sousa (1985: 156), se trata de una costumbre de origen estadounidense. Un ejemplo muy conocido: JFK por John F. Kennedy. 


\section{DisCURSO Directo}

Se ha dicho que el concepto de discurso directo "es tan transparente que nunca ha planteado problemas de definición". ${ }^{1}$ Acaso por ello su estudio no ha despertado el mismo interés que otras variedades del discurso ajeno, muy en particular el discurso indirecto. Ni siquiera ha logrado generar el mismo interés el hecho de que el discurso directo existe en todas las lenguas y el indirecto no. ${ }^{2}$ Este modo de referir las palabras ajenas — conocido también como estilo directo u oratio recta- presenta, sin embargo, "no pocos problemas, algunos de los cuales afectan a su misma naturaleza". 3

Desde muy antiguo nos viene la idea de que el discurso directo se caracteriza por una intención de literalidad, ${ }^{4}$ es decir, por suponer que "el que habla o escribe cita textualmente las palabras con que se ha expresado el propio autor de ellas".5 Debido a esa repetición, aparentemente fiel, Loc 1 asume por un momento el papel de Loc 2, esto es, finge expresarse como él. Es por ello que, desde Platón, ${ }^{6}$

\footnotetext{
${ }^{1}$ Rubio 1976: 65.

${ }^{2} \mathrm{Li}$ 1986: 39. Es por ello que, para algunos autores, el discurso directo es el estado inicial del proceso de gramaticalización que ha dado origen a todas las demás variedades del discurso ajeno (Girón Alconchel 2006: 400).

${ }^{3}$ Gutiérrez Ordóñez 1986: 23.

${ }^{4}$ Lázaro Carreter (1980: 160) emplea el término lenguaje literal en alusión a "comunicaciones que deben ser descifradas en sus propios términos, y que así deben conservarse". Aquí se utiliza con el mismo significado.

${ }^{5}$ Gili Gaya 1967 §219.II; $c f$. RAE y AALE 2005: 763, 2009: §43.9a y 2010b: §3.4.4.2.3, (1931) 1962: §382 y 1973: §3.19.4a, Jespersen (1924) 1968: 349, Todorov (1968) 1975: 59, Alcina y Blecua (1975) 2001: \$8.4.1, Leech y Short 1981: 318, Coulmas 1985: 42 y 1986: 2, Comrie 1986: 266, Maldonado 1991: 20, Cate 1996: 190, Nølke, Fløttum y Norén 2004: 65, entre muchos otros. Verdín Díaz (1970: 31), por ejemplo, defiende la idea de la repetición exacta, íntegra y objetiva de las palabras ajenas: "Se limita el estilo directo a expresar íntegramente, con toda objetividad, las mismas palabras del hablante".

${ }^{6}$ República, III: §597a.
} 
el discurso directo ha sido frecuentemente descrito como "histriónico", "dramático" o "mimético". 7

Bien apunta Maingueneau que no es sino en virtud de una "ley del discurso" "que se consideran minuciosamente exactas las palabras que Loc 1 imputa a Loc 2 . No obstante dicho supuesto, añade este autor, una atribución de palabras sensiblemente diferentes no implica, en principio, que Loc 1 mienta. Ducrot se expresa en el mismo sentido: "Que el estilo directo implique hacer hablar a otro, hacerle asumir emisiones, esto no significa que su verdad resida en una correspondencia literal, término a término". " Las Academias añaden que el discurso directo admite "una gradación que va desde la transcripción exacta de la secuencia emitida [...] hasta traducciones o reelaboraciones más o menos aproximadas". ${ }^{10}$ Banfield, ${ }^{11}$ Sternberg, ${ }^{12}$ Strauch, ${ }^{13}$ Tannen, ${ }^{14}$ Clark y Gerrig, ${ }^{15}$ Perridon, ${ }^{16}$ Noh $^{17}$ y Sakita ${ }^{18}$ llegan a conclusiones muy similares. ${ }^{19}$ Mayes $^{20}$ incluso ha demostrado que, en el habla informal, muchas de las supuestas citas directas son inventadas. Esta situación ha ocasionado que la aparente literalidad del discurso directo haya recibido frecuentemente rótulos como "ilusión linguiística", "ilusión retórica", 22 "simulacro", 23 "ficción discursiva". ${ }^{24}$

\footnotetext{
${ }^{7}$ Por ejemplo, Genette (1972) 1989: 229 y (1993) 1998: 36, Wierzbicka 1974: 272, Bal (1978) 1990: 144, Van Dijk (1980) 1990: 130, Ducrot (1984) 1986: 201, Li 1986: 38, Macaulay 1987, Reyes 1994a: 612.

${ }^{8}$ Maingueneau 1981: 99.

${ }^{9}$ Ducrot (1984) 1986: 204.

${ }^{10}$ RAE y AALE 2009: §43.9e.

${ }^{11}$ Banfield (1982) 1995.

${ }^{12}$ Sternberg 1982.

${ }^{13}$ Strauch 1984.

${ }^{14}$ Tannen 1989.

${ }^{15}$ Clark y Gerrig 1990.

${ }^{16}$ Perridon 1996.

${ }^{17}$ Noh 2000.

${ }^{18}$ Sakita 2002.

${ }^{19}$ Parece comprobar esta hipótesis el hecho de que a nadie extrañen las expresiones del tipo Lo dijo así, tal como lo oyes o ¿Lo dijo con esas palabras?

${ }^{20}$ Mayes 1990.

${ }^{21}$ Maingueneau 1981: 99.
} 
Autores como Van Dijk, ${ }^{25}$ Slembrouck, ${ }^{26}$ Bruña Cuevas, ${ }^{27}$ Waugh, ${ }^{28}$ Fuller $^{29}$ y Méndez García de Paredes ${ }^{30}$ han demostrado que ni siquiera en el discurso periodístico —donde las palabras de Loc 2 son empleadas por Loc 1 como recurso de credibilidad $^{31}$ - se cumple siempre la correspondencia ad pedem litterae que dicho estilo discursivo sugiere. ${ }^{32}$ En realidad, según $\mathrm{Waugh}^{33}$ esto casi nunca ocurre. ${ }^{34} \mathrm{Al}$ respecto comenta Van Dijk: "Es irrelevante que las citas rara vez sean completamente correctas en el sentido contextual. Sólo deben sugerir que son verdaderas, de ahí su función retórica y sus efectos”.35

Incluso en los casos de mayor similitud formal entre la cadena sintagmática resultante de la enunciación secundaria y su representación en la enunciación primaria, es imposible reproducir el significado íntegro del texto: recuérdese que el simple desplazamiento de contexto altera el sentido del enunciado, pues la caracterización semántica del texto se encuentra determinada por todo el acto de comunicación verbal, irrepetible por naturaleza y solo parcialmente constituido

\footnotetext{
${ }^{22}$ Van Dijk (1980) 1990: 130.

${ }^{23}$ Reyes 1993: 24.

${ }^{24}$ Méndez García de Paredes 2000a: 154.

${ }^{25}$ Van Dijk (1980) 1990.

${ }^{26}$ Slembrouck 1992.

${ }^{27}$ Bruña Cuevas 1993.

${ }^{28}$ Waugh 1995.

${ }^{29}$ Fuller 1996.

${ }^{30}$ Méndez García de Paredes 2000a.

${ }^{31} C f$. Van Dijk (1980) 1990: 130, Gutiérrez Ordóñez 1986: 36, Romero Álvarez 2000, Benavent Payá 2003: 18, López Pan 2004: 204, entre otros. Para las pretensiones de obtención de credibilidad del discurso directo en contextos no narrativos, $c f$. Baynham 1996, Vincent y Perrin 1999.

${ }^{32}$ Para una discusión desde el punto de vista de la ética periodística, $c f$. López Pan 2004: 205 214.

${ }^{33}$ Waugh 1995: 156.

${ }^{34}$ En cuanto a la existencia de registros electrónicos, como grabaciones magnetofónicas, Méndez García de Paredes (2000b: 155), luego de una rigurosa comparación intertextual, concluye: "Que exista un producto original, que éste haya quedado grabado y que sea posible comparar lo referido, no significa que la literalidad sea definidora del D[idcurso]D[irecto] en el texto periodístico".

${ }^{35}$ Van Dijk (1980) 1990: 130; $c f$. RAE y AALE 2009: §43.9e.
} 
por el texto. De hecho, observa Maingueneau, ${ }^{36}$ un fragmento del discurso de Loc 2 puede parecer una copia fiel del original y encontrarse, en realidad, notablemente deformado por un contexto tendencioso. ${ }^{37}$ A propósito, Reyes advierte: "Debemos desechar la idea ingenua de que la repetición literal de un texto garantiza que podamos recuperar todo el significado de ese texto". 38

Con la inherente simulación de literalidad, el discurso directo supone también la representación de la enunciación como doble. Dicho de otro modo, en esta variedad de discurso ajeno queda representada "la presencia simultánea de dos actos de enunciación": 39 el de Loc 1 y el de Loc 2. Debe destacarse, sin embargo, que en realidad no se trata más que de una representación, puesto que no existe sino una única unidad comunicativa, denunciada no por la coincidencia, sino por "la obligatoriedad de pertenecer a un mismo acto de enunciación (con un mismo emisor, idéntico receptor y circunstancias)". ${ }^{40}$ Así pues, en todos los casos de discurso directo, Loc 1 repite, en una nueva situación enunciativa y de manera histriónica, las palabras supuestamente emitidas por Loc 2.

Puesto que cada acto de enunciación — representado o no- es denunciado por un eje deíctico distinto, la introducción del segmento correspondiente a la enunciación secundaria ocasiona que Loc 1 abandone temporalmente su propio eje deíctico y adopte el de Loc $2 .^{41}$ Como se sabe, los deícticos - también llamados marcadores de embrague, conmutadores, indicios o shifters -42 son

\footnotetext{
${ }^{36}$ Maingueneau 1981: 99.

${ }^{37}$ Cf. Van Dijk (1977) 1980: 274.

${ }^{38}$ Reyes 1993: 22. Cursivas en el original.

${ }^{39}$ Rivarola y Reisz de Rivarola 1984: 152; cf. Ducrot (1984) 1986: 203.

${ }^{40}$ Gutiérrez Ordóñez 1986: 26.

${ }^{41}$ Cf. Li 1986: 34, Coulmas 1994: 3552, Maingueneau 1981: 99, Girón Alconchel 1989: 74-75, Bruña Cuevas y Muñoz 1992: 226-243, Reyes 1993: 15, Vicente Mateu 1994: 117-118, Van der Houwen 2000: 28, Vandelanotte 2004: 489-520, entre otros.

${ }^{42} \mathrm{Si}$ bien algunos lingüistas han planteado diferencias entre los significados de estas palabras, todas ellas se utilizan de manera habitual para apelar esencialmente a lo mismo. Las distinciones que se han sugerido no alteran en absoluto las conclusiones de esta investigación.
} 
formas lingüísticas cuyo referente solo puede ser determinado con relación a la identidad o a la situación espacio-temporal del hablante ${ }^{43}$ en momento de la enunciación; ${ }^{44}$ en español, son típicamente deícticos los pronombres personales y demostrativos, los adverbios de lugar y tiempo, y los morfemas flexivos de tiempo y persona. Se ha comprobado que la retención del sistema deíctico de la enunciación original es el rasgo más importante del discurso directo. ${ }^{45}$

En principio, el discurso directo se caracteriza, pues, por la retención del sistema deíctico de Loc 2 y una concomitante intención mimética o histriónica por parte de Loc 1. Esto significa que se conserva el punto de referencia de la enunciación originaria, lo que también permite reproducir gestos, sonidos e interjecciones, ${ }^{46}$ mantener vocativos y formas verbales en imperativo ${ }^{47}$ y, en la expresión oral, repetir o imitar entonaciones. ${ }^{48}$ En el caso de los titulares de prensa, Loc 2 corresponde a la fuente periodística, es decir, a la persona que produjo una declaración cuyo contenido ha sido considerado de interés noticioso. Loc 1, el periodista, produce una representación del enunciado de Loc 2, no necesariamente literal en el más estricto sentido, en la que mantiene anclados los deícticos en la situación enunciativa originaria.

(1) a. "No admito que por un truco haya seres humanos sin sanidad o escuela" [ELP 21/01/10: 1]

\footnotetext{
${ }^{43}$ Brecht (1974), Kerbrat-Orecchioni (1980: 47), Comrie (1986: 269-270) y las Academias (RAE y AALE 2009: §43.10.1), entre otros autores, distinguen también algunos deícticos cuyo referente se halla en el contexto lingüístico, como el día anterior, dos horas antes o mientras tanto. Brecht (1974) los llama endofóricos.

${ }^{44}$ Bühler (1934) 1961: cap. 2, Jakobson (1936-1963) 1981: cap. 12, Benveniste (1966) 2001: cap. 5, Kerbrat-Orecchioni 1980: cap. 2, Levinson (1983) 1989, Lyons (1995) 1997: cap. 10; RAE y AALE 2009: 43.10e-43.10k, entre muchos otros.

${ }^{45}$ Banfield 1973: 3, Comrie 1986: 266-273, Coulmas 1986: 2 y 1994: 3553, Vandelanotte 2004, Reyes1993: 15 y 1994a: 592, Vicente Mateu 1994: 117-118, entre otros.

${ }^{46}$ Cameron 1998, entre otros.

${ }^{47}$ Verdín Díaz 1970: 32, entre otros.

${ }^{48}$ Kvavik 1986: 337. En cuanto a la entonación propia del discurso directo, ya ha observado Briz (1995: 45-46) la presencia casi sistemática de un tonema suspendido entre el verbo de habla y las palabras de Loc 2 .
} 
b. Niurka Marcos: "No me importa que le digan gay a mi pareja" [HOY 18/01/10: 2D]

c. Soy el cocinero del cine: Luc Besson [UNI 24/01/10: K15]

En los titulares de la serie (1), por ejemplo, los pronombres personales y los adjetivos posesivos, así como los morfemas de persona en la flexión verbal, revelan claramente un eje deíctico anclado en un Loc 2, es decir, un locutor distinto del periodista que redacta el encabezado. En (1a), Loc 2 es el presidente del Gobierno español, José Luis Rodríguez Zapatero, y, en (1b) y (1c), la bailarina cubana Niurka Marcos y el cineasta francés Luc Besson, respectivamente. Los ejemplos (1b) y (1c) contienen, además del enunciado reproducido, frases nominales que apelan a los respectivos locutores secundarios en estructuras características del discurso de los encabezados periodísticos de las que hablaremos más adelante.

A causa de esta retención del sistema deíctico, se ha dicho que el discurso directo supone un contexto opaco: ${ }^{49}$ hay transparencia referencial si es aplicable el principio de sustitución de idénticos, de Leibnitz, y es opaco si no es aplicable. Según dicho principio, dos o más denominaciones son correferenciales si pueden ser intercambiadas sin alterar el valor de verdad del enunciado. Así pues, los ejemplos bajo (1) son contextos opacos: el referente de los pronombres y morfemas flexivos de primera persona es Loc 2 y no Loc 1.

En el discurso periodístico es frecuente lo que, desde Benveniste, se conoce como enunciación histórica, caracterizada por referencias pronominales en tercera persona, tiempo narrativo pretérito $^{50}$ y ausencia de elementos exponentes

\footnotetext{
${ }^{49}$ Por ejemplo, Maldonado 1991: 69-72, RAE y AALE 2009: 43.10c.

${ }^{50}$ En los titulares periodísticos, lo más frecuente es el uso del presente histórico, que, como se sabe, es empleado para referir hechos pasados. Según datos de Guízar (2004: 68) sobre prensa mexicana, se halla en presente de indicativo aproximadamente el $73 \%$ de los verbos en titulares con verbo expreso. Los materiales de Thogmartin (1991: 260) sobre prensa francesa arrojan exactamente la misma cifra. Diversas son las interpretaciones que se han dado al uso del
} 
de la expresividad del hablante. En buena parte de estos casos, que en mis materiales se distribuyen en la categoría que llamo discurso directo marcado, resulta extremadamente difícil — si no es que imposible - hablar de anclajes deícticos de persona, y a veces también de tiempo y espacio. Esto, sin embargo, no impide al receptor interpretar como retransmisiones algunos segmentos discursivos que presentan las características mencionadas.

De acuerdo con el principio, consolidado por la gramática de construcciones, ${ }^{51}$ de la correspondencia irrenunciable entre forma y significado, que no solo alcanza al signo, sino a cualquier tipo de estructura gramatical, es posible asociar una configuración sintáctica abstracta con un polo semántico propio. Para nuestro caso, vale decir que una serie de construcciones, vinculadas entre sí por medio de concatenaciones metonímicas, se asocian convencionalmente con un significado general de supuesta retransmisión literal y su concomitante retención de anclaje deíctico. En otras palabras, este significado básico es una instrucción interpretativa inherente a todos los enunciados en discurso directo.

El discurso directo registra una abundante variedad de construcciones, que se distinguen a partir de la oposición inicial entre discurso directo marcado y no marcado, la cual ha sido casi totalmente ignorada por la tradición gramatical: esta, casi sin excepción, ha identificado únicamente el discurso directo marcado, que es, según Hickmann, ${ }^{52}$ solo la forma más obvia del discurso directo. Por marca entiendo toda indicación explícita de Loc 1 de que en el texto hay una reproducción textual, con pretensión de literalidad o no. En algunos casos, es

presente en los titulares periodísticos: Alcoba Rueda (1983 y 1984), por ejemplo, dice que posee un valor anafórico y no uno deíctico; para Alarcos (1977: 147), en cambio, es una simple neutralización de valores temporales.

${ }^{51}$ Fillmore 1982, Goldberg 1995, Kay 1997, entre otros.

${ }^{52}$ Hickmann 1993: 63. 
necesario añadir el criterio de complejidad estructural: ${ }^{53}$ dado un contraste entre dos elementos comparables, el más complejo será el marcado.

Del total de mis materiales, el 12\% (443/3689) corresponde al discurso directo. En el siguiente cuadro se exhiben las frecuencias relativas de uso para el total de titulares con discurso ajeno en cada periódico: ${ }^{54}$

\begin{tabular}{|l|l|}
\hline \multicolumn{1}{|c|}{ Diario } & $\begin{array}{c}\text { Frecuencia relativa } \\
\text { de uso }\end{array}$ \\
\hline El País (Madrid) & $19 \%(48 / 253)$ \\
\hline La Opinión (Los Ángeles) & $2,7 \%(4 / 149)$ \\
\hline El Universal (México) & $16 \%(101 / 630)$ \\
\hline La Nación (San José de Costa Rica) & $10,3 \%(31 / 301)$ \\
\hline Hoy (Santo Domingo) & $3,4 \%(18 / 531)$ \\
\hline El Tiempo (Bogotá) & $14,3 \%(41 / 286)$ \\
\hline El Nacional (Caracas) & $14 \%(52 / 372)$ \\
\hline El Comercio (Lima) & $8,8 \%(35 / 400)$ \\
\hline El Mercurio (Santiago de Chile) & $12,2 \%(53 / 436)$ \\
\hline Clarín (Buenos Aires) & $18,1 \%(60 / 331)$ \\
\hline
\end{tabular}

Puede advertirse que los periódicos El País y Clarín formulan en discurso directo casi la quinta parte de todos sus encabezados con discurso ajeno y que la frecuencia de uso en El Universal no se aleja mucho de esa proporción. La incidencia del discurso directo en Hoy y La Opinión - inferior en ambos casos al 4\% - revela una más acusada resistencia al empleo de esta modalidad del discurso ajeno. El Tiempo, El Nacional, El Mercurio, La Nación y El Comercio,

\footnotetext{
53 Givón 1995: 28.

${ }^{54}$ Por diarios, la distribución global del discurso directo es la siguiente: El País, 10,8\% (48/443); La Opinión, 0,9\% (4/443); El Universal, 22,8\% (101/443); La Nación, 7\% (31/443); Hoy, 4,1\% (18/443); El Tiempo, 9,3\% (41/443); El Nacional, 11,7\% (52/443); El Comercio, 7,9\% (35/443); El Mercurio, 12\% (53/443); Clarín, 13,5\% (60/443).
} 
en cambio, no presentan variaciones importantes con respecto a la media aritmética del $12 \%$.

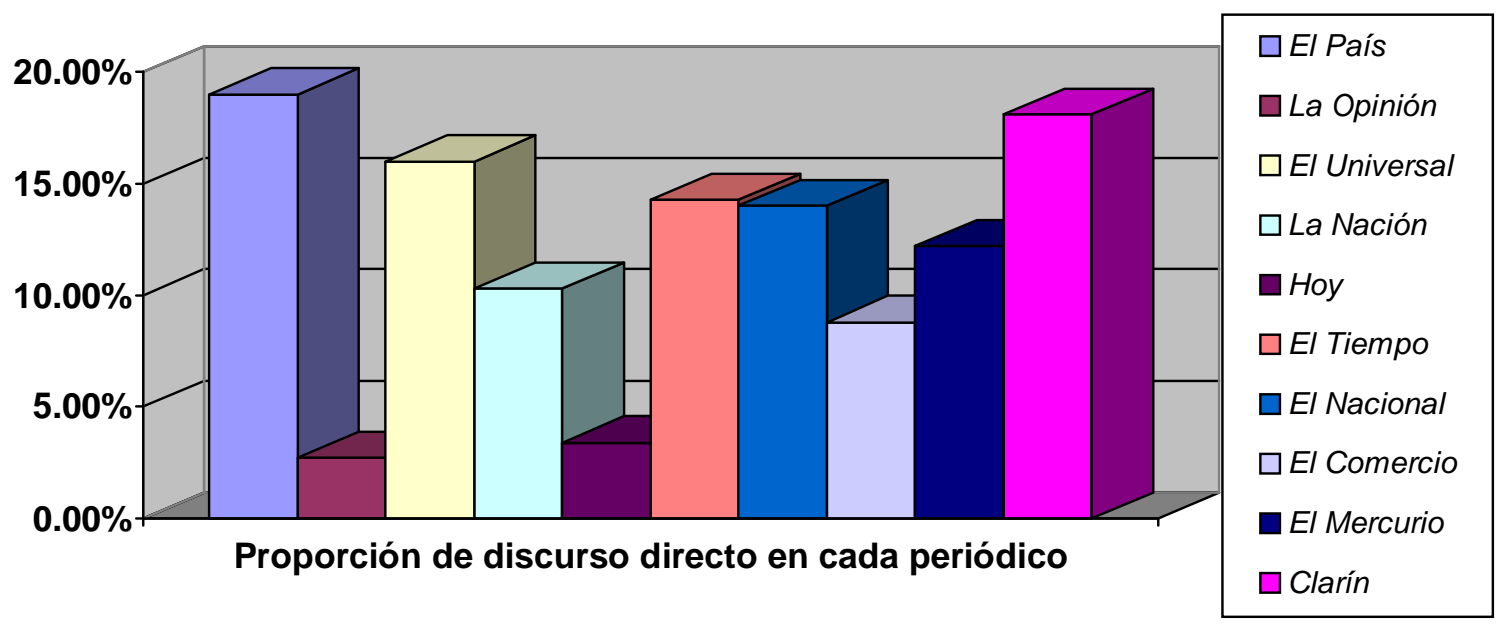

El $96 \%$ de los titulares en discurso directo de los cinco diarios (426/443) está representado por el directo marcado, y solo el $4 \%$ (17/443) por el no marcado. A pesar de la mínima incidencia de este último, considero que sus particulares implicaciones pragmáticas justifican un análisis independiente.

\subsection{Discurso directo marcado}

Por marca de discurso directo habremos de entender, pues, cualquier forma que se añada al presunto enunciado de Loc 2 para sugerir la existencia de una retransmisión literal. Puede ser morfológica, sintáctica, ortográfica o suprasegmental, siempre que se trate de un exponente formal, explícito, añadido al enunciado de Loc 2: la adición formal al supuesto enunciado originario conlleva, desde luego, un aumento de complejidad estructural. Quedan excluidas, por ende, todas las marcas implícitas, frecuentemente aludidas por la teoría literaria, como la distintiva manera de hablar de un personaje. 
En mis materiales solamente registro, como marcas, verbos de habla subordinantes e índices gráficos. Las marcas gráficas son las más abundantes: representan el 58,2\% (248/426). Los verbos de habla subordinantes, en cambio, constituyen marcas de discurso directo en el 25,8\% de los casos (110/426). El $16 \%$ restante (68/426) corresponde a los casos que presentan una doble marca, es decir, tanto verbo subordinante como índice gráfico. Es preciso aclarar, sin embargo, que los periódicos La Opinión (Los Ángeles) y, sobre todo, El Universal (México) se alejan significativamente de esta tendencia general: en ellos, los verbos de habla son las marcas predominantes. Cabe señalar, asimismo, que el diario Hoy (Santo Domingo) presenta más casos de marcas dobles que de índices gráficos empleados como marcas únicas de discurso directo, y que en $E l$ País (Madrid) y El Mercurio (Santiago de Chile) no hallé casos de verbo subordinante como marca única de retransmisión directa. ${ }^{55}$

Antes de exponer las características de estas marcas, es preciso detenerse para atender un punto relativamente conflictivo con relación a la deixis personal en el discurso directo: el de los enunciados que solo ostentan marcas de tercera persona. Hemos dicho que el discurso directo se caracteriza, en principio, por la retención del sistema deíctico de la enunciación secundaria, situación que, de acuerdo con diversos especialistas, produce un contexto opaco y,

55 He aquí la relación exhaustiva:
\begin{tabular}{|l|l|l|l|}
\hline & Verbo subordinante & Índices gráficos & Doble marca \\
\hline El País & $0 \%(0 / 48)$ & $90 \%(43 / 48)$ & $10 \%(5 / 48)$ \\
\hline La Opinión & $50 \%(2 / 4)$ & $25 \%(1 / 4)$ & $25 \%(1 / 4)$ \\
\hline El Universal & $85 \%(82 / 96)$ & $7 \%(7 / 96)$ & $7 \%(7 / 96)$ \\
\hline La Nación & $6 \%(2 / 31)$ & $84 \%(26 / 31)$ & $10 \%(3 / 31)$ \\
\hline Hoy & $29 \%(5 / 17)$ & $29 \%(5 / 17)$ & $41 \%(7 / 17)$ \\
\hline El Tiempo & $13 \%(5 / 40)$ & $80(32 / 40)$ & $8 \%(3 / 40)$ \\
\hline El Nacional & $19 \%(10 / 52)$ & $63 \%(33 / 52)$ & $17 \%(9 / 52)$ \\
\hline El Comercio & $11 \%(3 / 28)$ & $82 \%(23 / 28)$ & $7 \%(2 / 28)$ \\
\hline El Mercurio & $0 \%(0 / 52)$ & $60 \%(31 / 52)$ & $40 \%(21 / 52)$ \\
\hline Clarín & $2 \%(1 / 58)$ & $81 \%(47 / 58)$ & $17 \%(10 / 58)$ \\
\hline
\end{tabular}


consecuentemente, un efecto histriónico. Esto es evidente cuando el enunciado secundario ostenta marcas de primera o segunda persona:

(2) a. Chávez, a sus seguidores: "Elijo lealtad absoluta" [CLA 24/01/10: 24]

b. Evo Morales: "Estados Unidos fue mi mejor jefe de campaña" [ELN 23/01/10: A11]

c. 'Yo quiero jugar béisbol, papi' [TРО 23/01/10: 1-16]

d. "Tuve la impresión de caerme en un pozo" [ELP 23/01/10: 35]

e. Ojalá te pudras, le gritan a asesino de una joven en Juárez [SOL 22/02/05: $1 / \mathrm{B}]$

Ya Benveniste ${ }^{56}$ observó que estas — la primera y la segunda — son las "personas únicas", pues solamente hay un yo y un tú en cada enunciación. Esto permite que, en casos como los de (2), se evidencie la retención que Loc 1 hace del sistema deíctico de Loc 2: los contextos son opacos por cuanto las marcas personales que aluden al locutor y al alocutario de la enunciación secundaria no corresponden con el locutor y el alocutario de la enunciación primaria. En (2a), el locutor de la enunciación secundaria es el presidente de Venezuela, Hugo Chávez, y los alocutarios, sus seguidores. Los locutores secundarios de (2b) y (2d) son, respectivamente, el presidente de Bolivia, Evo Morales, y Emmanuelle Seigner, la mujer del cineasta Roman Polanski. En (2e), el locutor de la enunciación secundaria es la madre de una joven asesinada, y el asesino, el alocutario. El titular (2c) reproduce ciertas palabras que el beisbolista colombiano Jorge Mario Alfaro le dijo a su padre cuando era niño. En los cinco casos, al igual que en todos los encabezados periodísticos, el locutor de la enunciación primaria es el periodista que redacta el titular, y su alocutario, el lector o el público lector.

Ahora bien, resulta obvio que la identidad del sujeto de la enunciación secundaria no es recuperable por medio de marcas de primera o segunda persona cuando estas no están presentes en el enunciado. Es el caso de los titulares bajo (3):

\footnotetext{
${ }^{56}$ Benveniste (1966) 2001.
} 
(3) a. 'Neville es un tarado', dice Tevez [OPI 22/01/10: 2C]

b. El pueblo de EU está enojado, dice Barack [UNI 21/01/10: A25]

c. Carlin: "Mandela iba 500 años por delante de los políticos de hoy" [ELN 24/01/10: D9]

d. "Ella ha elogiado labor del Banco Central" [COM 20/01/10: B2]

Para Benveniste, ${ }^{57}$ la tercera persona es la "no-persona", pues no tiene derecho al habla en el diálogo: mientras que en cada enunciación hay solamente un yo y un tú, hay muchos él posibles. ${ }^{58} \mathrm{El}$ hecho de que la tercera persona tome como referente toda entidad que no participe directamente en el acto de comunicación ocasiona que se conserve la transparencia referencial del enunciado originario cuando Loc 1 reproduce en discurso directo un enunciado de Loc 2 que solo contiene marcas de tercera persona. Es decir: si Loc 2 expresa un él en su enunciado, y este no es correferencial a Loc 1 o a su alocutario, seguirá expresándose como un él en el texto de Loc 1, aunque haya retención del sistema deíctico. En principio, si una entidad no está presente en el cuadro figurativo ${ }^{59} \mathrm{de}$ la enunciación primaria o secundaria, estará representada, en ambos enunciados, por formas de tercera persona.

Si bien la deixis trasciende el asunto de la referencia de las personas gramaticales y los pronombres en cuanto indicios del anclaje situacional —como puede advertirse, por ejemplo, en el adverbio hoy, de (3c), o en los tiempos verbales de los segmentos entrecomillados de (2b), (2c) y (2d), que están referidos sin duda a la situación enunciativa de Loc 2-, son los deícticos personales las únicas entidades de referencia situacional que permiten reconocer la identidad de Loc 2 como participante en el cuadro figurativo de la enunciación secundaria. La

\footnotetext{
${ }^{57} \mathrm{Ibid}$.

${ }^{58}$ Aunque, por diversas razones, Kerbrat-Orecchioni (1980: 43) considera impropio el apelativo "no-persona", coincide con Benveniste en que el pronombre personal él requiere determinaciones cotextuales que pueden no ser el yo o el tú.

${ }^{59}$ Benveniste (1974) 2002: 88.
} 
ausencia de marcas de primera o segunda persona, sin embargo, no obsta para la cabal identificación de Loc 2 en el discurso directo marcado: puede conseguirse por medio de marcas no deícticas.

El receptor puede, pues, interpretar como retransmisiones supuestamente literales algunos segmentos discursivos que no presentan marcas de primera o segunda persona. Esto se debe a que el polo semántico de la retransmisión directa está asociado a configuraciones sintácticas u ortográficas abstractas: recuérdese que la correspondencia irrenunciable entre forma y significado no solo alcanza al signo, sino a cualquier tipo de estructura lingüística. ${ }^{60}$ El surgimiento de dicha asociación convencional no puede deberse más que al uso rutinario de estructuras que responden a necesidades específicas de comunicación.

Forman parte medular de tales construcciones estereotipadas las entidades lingüísticas que aquí he llamado marcas de discurso directo. Como he dicho, en mi corpus figuran como tales los verbos de habla subordinantes, algunos índices gráficos y combinaciones de ambos.

\subsubsection{Verbo subordinante}

Suele admitirse que el discurso directo "requiere por lo general la presencia de un verbo introductor como decir, explicar, manifestar, opinar, repetir o responder, entre otros". ${ }^{61}$ En efecto, las definiciones tradicionales del discurso directo coinciden en señalar que el primitivo enunciado de Loc 2 se halla subordinado, en función de objeto directo, a una oración principal, atribuida solamente a Loc

\footnotetext{
${ }^{60} C f$. Fillmore 1982, Goldberg 1995, Kay 1997, entre otros.

${ }^{61}$ RAE y AALE 2009: $\$ 43.9 b$.
} 
1, que contiene un verbo de habla. ${ }^{62}$ Es común asumir que entre ambas secuencias media una relación funcional de subordinación objetiva directa, ${ }^{63}$ a pesar de la ausencia de nexos (situación que ha llevado a algunos a hablar de una relación adicional de yuxtaposición) ${ }^{64}$.

La estructura sintáctica de esta construcción, que según Wierzbicka ${ }^{65}$ es la forma básica del discurso ajeno, se compone de dos partes: el modus, ${ }^{66}$ también llamado, para estos casos, marco de la cita $^{67}$ o expresión introductora, ${ }^{68}$ y el dictum o contenido citado, ${ }^{69}$ que es la cita misma, es decir, el supuesto enunciado de Loc 2.

El modus, atribuido siempre a Loc 1, consta de una oración subordinante conformada por un verbo de habla, expreso o elíptico, que "ocupa diversas posiciones", 70 y "algunos de los elementos de la enunciación originaria (emisor, receptor, circunstancias...)". ${ }^{71}$ A partir de ahora llamaré segmento 1 a este fragmento textual. Prefiero este término, y no "expresión introductora" o "marco de la cita”, porque, como veremos más adelante, no siempre antecede a las palabras de Loc 2 y casi nunca las rodea. Llamaré segmento 2 a la expresión citada o dictum.

\footnotetext{
${ }^{62}$ Gili Gaya 1967: §219.II, RAE 1973: §3.19.4c, Alcina y Blecua (1975) 2001: §8.4.1, Cano Aguilar 1981: 209, Gutiérrez Ordóñez 1986: 26, Maldonado 1991: 30, Reyes 1993: 15, Gómez Torrego 2002: \$3.3.4.2, entre muchos otros.

${ }^{63}$ Es esta la posición que ha seguido la tradición gramatical hispánica, de acuerdo con Lope Blanch (1983: §5.3.2.3).

${ }^{64}$ Por ejemplo, Gili Gaya 1967: §219.II, RAE 1973: §3.19.4c, Alcina y Blecua (1975) 2001: §8.4.1, Lope Blanch 1983: §5.3.2.3, Alarcos 1994 1999: §387.

${ }^{65}$ Wierzbicka 1974: 272.

${ }^{66}$ Lips 1926: 17.

${ }^{67}$ Reyes 1993: 15 y 1994a: 591.

${ }_{68}^{68}$ Maldonado 1991: 30.

${ }^{69}$ Ibid.

${ }^{70}$ RAE y AALE 2010a: §43.4.1a. Cf. Verdín Díaz 1970: 33-36, entre otros.

${ }^{71}$ Gutiérrez Ordóñez 1986: 26.
} 
(4) a. Dice Bours: no firmo en blanco [REF 9/01/09: 4]

$\mathrm{S} 1 \mathrm{~S} 2$

b. No agredimos a la Orcao , dicen zapatistas [JOR 7/01/09: 10]

S2 S1

S1: Segmento 1 (nivel discursivo primario)

S2: Segmento 2 (nivel discursivo secundario)

El segmento 1 está conformado siempre, pues, por una oración con un verbo de habla. El segmento 2, en cambio, puede estar compuesto por oraciones o fragmentos sintácticos menores. ${ }^{72}$ Ambos segmentos están siempre perfectamente separados: ${ }^{73}$ en lo oral, por pausas y un contorno melódico autónomo, y en la escritura, por diversos procedimientos grafémicos y ortográficos. ${ }^{74} \mathrm{Si}$ bien esta singularidad — aunada a la ausencia de nexos- ha llevado a algunos a pensar que los segmentos 1 y 2 son absolutamente independientes entre sí y que, por consiguiente, no podría haber relación hipotáctica, ${ }^{75}$ se ha atribuido a la pausa —representada en la enunciación escrita por diversos signos - la función transcategorizadora que permite incorporar el supuesto enunciado de Loc 2 como objeto directo del verbo de habla.

En su trabajo de caracterización del discurso directo, Gutiérrez Ordóñez propone lo anterior y esgrime los siguientes argumentos a favor de la naturaleza

\footnotetext{
${ }^{72}$ RAE y AALE: $\$ 43.4 .1 \mathrm{~b}$, entre otros.

${ }^{73}$ Maingueneau 1981: 98-99, por ejemplo.

${ }^{74}$ Alcina y Blecua (1975) 2001: $\$ 8.4 .1$, Maldonado 1991: 30, Reyes 1993: 15, entre otros.

${ }^{75}$ Por ejemplo, Verdín Díaz (1970: 31): "Las dos frases se completan y necesitan la una de la otra para componer una unidad de sentido, pero ambas se pueden considerar como frases independientes". En el mismo sentido, Lenz (1935: 209, nota) afirma: "Formalmente no hay relación entre el verbo de decir y lo dicho; la relación es exclusivamente lógica”. Según Girón Alconchel (1989: 78), se trata de "un caso de coordinación asindética". Para Maldonado (1999: 3570-3571), en esta modalidad de discurso directo se presenta una relación de yuxtaposición o adyacencia sintáctica más que dependencia sintáctica (presenta como argumentos dos diferencias de comportamiento entre discurso directo y discurso indirecto, pues, de acuerdo con ella, en este último sí hay subordinación: 1] la negación implícita de los verbos que significan 'decir que no', como negar o desmentir, no alcanza al segmento 2 - La actriz desmintió: "No estoy embarazada"-, y 2] las expresiones referenciales en la cita directa y la indirecta se interpretan de distinto modo).
} 
subordinada objetiva directa del segmento $2:^{76}$ 1) este puede sustituirse por el pronombre lo en la mayoría de $\operatorname{los}$ casos $;^{77}$ 2) los segmentos 1 y 2 jamás se enlazan por medio de un nexo coordinante; 3) el segmento 1 puede interpolarse en el segmento $2,^{78}$ y 4) el segmento 2 responde a la pregunta ¿qué...?, a diferencia de todas las funciones distintas del objeto directo, sujeto y atributo, y, puesto que no se trata ni de sujeto ni de atributo, será necesariamente un objeto directo. Este autor añade que el segmento 2 es también, "a veces, suplemento". 79

Puesto que, naturalmente, el eje deíctico del segmento 1 es Loc 1 , y el del segmento 2, Loc 2, y que hay límites claros aunados a una relación de dependencia entre ambos segmentos, ha sido hasta cierto punto habitual hablar de un "cambio de niveles discursivos" ${ }^{80}$ en el discurso directo.

En el nivel primario $^{81}$ —donde el segmento 1 se ubica-, Loc 1 normalmente presenta una propuesta de evaluación tanto del enunciado y de la enunciación de Loc 2 como de "los personajes cuyos hechos verbales y no verbales narra, evaluación que aspira a ser compartida por su interlocutor". ${ }^{82}$ En buena medida, dicha evaluación recae en la selección léxica concreta que, del vasto inventario de verbos de habla, hace Loc 1.

\footnotetext{
${ }^{76}$ Gutiérrez Ordóñez 1986: 28-34.

${ }^{77}$ Esto no ocurre en verbos como responder: María respondió: "Estás equivocado", pero * María lo respondió. Sucede lo mismo con el discurso indirecto, sin que por ello se dude del carácter subordinado objetivo directo del segmento que representa las palabras de Loc 2: María respondió que estaba equivocado, pero *María lo respondió. Esta situación lleva a Guitérrez Ordóñez a proponer que existen complementos directos no conmutables por pronombre átono (véase también Alcina y Blecua [1975] 2001: §8.4.1.).

${ }^{78}$ Ejemplo de Gutiérrez Ordóñez: "Respecto de El último tango —comentó Bertolucci一, creo que es un filme político". No registro titulares con estas características.

${ }^{79}$ Gutiérrez Ordóñez 1986: 38.

${ }^{80}$ Por ejemplo, Rivarola y Reisz de Rivarola 1984: 164 y Fonte 1999: 142-143.

${ }^{81}$ Voloshinov (1929) 1992. Fonte (1999) lo llama "nivel secundario".

${ }^{82}$ Fonte 1999: 143.
} 
El nivel secundario aloja siempre el segmento 2. El cambio de nivel discursivo supone la existencia de un verbo de habla, expreso o elíptico, además de un esfuerzo adicional para el emisor y el receptor: Loc 1 "se ve obligado a quebrantar la línea de su discurso para incluir un cuerpo extraño en el normal desarrollo de su acto enunciativo", ${ }^{83}$ y al lector se le exige cierto cuidado para interpretar correctamente el contexto opaco que representa todo enunciado en discurso directo. Ambos niveles discursivos, dice Fonte, ${ }^{84}$ integran el espacio conceptual de la escena enunciativa.

Evidentemente, entiendo por verbo de habla todo verbo que denote un comportamiento verbal cualquiera, es decir, que exprese la realización de un acto lingüístico, sea cual fuere su naturaleza. ${ }^{85}$ Parece, por cierto, que no existe consenso en las clasificaciones de los también llamados "verbos de comunicación verbal", "verbos enunciativos", "verbos de "decir" o "verba dicendi"; tampoco existen, al menos para la lengua española, clasificaciones verdaderamente exhaustivas de este amplio dominio léxico. Llevar a buen término una investigación de tal envergadura excede por mucho los límites metodológicos de este trabajo; resultan necesarias, no obstante, algunas observaciones generales.

El dominio léxico de los verbos de habla constituye, pues, el área conceptual de la realización de actos lingüísticos de cualquier índole. Con todo verbo de habla se consigna un hecho de locución, o acto locucionario, en términos de Austin ${ }^{86}$. Decir es el más genérico de todos estos verbos: podría afirmarse que es el 'archilexema', pues refiere el puro hecho de locución. El resto añade

\footnotetext{
${ }^{83}$ Rivarola y Reisz de Rivarola 1984: 164.

${ }^{84}$ Fonte 1999: 143.

${ }^{85}$ Para algunos lingüistas, en toda frase que constituya una declaración o enunciación de algo, se debe interpretar que subyace un verbo de habla, aunque no aparezca de manera expresa.

${ }^{86}$ Austin (1962) 1971.
} 
especificaciones diversas a este significado referencial básico: explicitan la fuerza ilocucionaria (prometer, suplicar) o el modo de realización fónica (gritar, susurrar), presuponen la verdad o falsedad del discurso ajeno (revelar, mentir), o lo sitúan en la cronología discursiva (repetir, concluir). ${ }^{87}$ Esta información, añadida gracias a la selección léxica que Loc 1 hace luego de interpretar el acontecimiento lingüístico, condiciona directamente el modo como el receptor interpreta el enunciado de Loc 2: en otras palabras, impone una cierta lectura al destinatario. Todos estos verbos se distribuyen, por tanto, a lo largo de un continuum de subjetividad. ${ }^{88}$

En principio, los verbos de habla son activos: ${ }^{89}$ exigen —salvo en usos metafóricos - un agente humano, ya que "designan una de las actividades más específicas de los seres humanos". ${ }^{90}$ Normalmente, dicho agente desempeña la función de sujeto, y el objeto directo refiere el producto verbal de Loc $2 .^{91}$ Cuando llevan objeto indirecto, este normalmente es humano. ${ }^{92}$

Evidentemente, los verbos de habla no se distribuyen únicamente en el discurso directo: forman parte también de otras estructuras del discurso ajeno. Retomaré este asunto en la medida que la descripción general del corpus lo exija. Por lo pronto, baste saber que constituyen una marca de discurso directo y que, en los titulares, están de manera expresa o elíptica. ${ }^{93}$

\footnotetext{
${ }^{87}$ Cf. Maingueneau 1981: 101.

${ }^{88}$ Cf. Kerbrat-Orecchioni 1980.

${ }^{89}$ Zwicky 1971, Cano Aguilar 1981: 207, Maldonado 1991: 48.

${ }^{90}$ Cano Aguilar 1981: 207.

${ }^{91}$ Cano Aguilar (1981: 207) observa que estos verbos son básicamente transitivos, pues "implican necesariamente, aparte del sujeto que realiza el acto verbal, el contenido o tema de ese acto verbal". Munro (1982) no comparte dicho punto de vista: afirma, a partir de un estudio comparativo del inglés y de varias lenguas americanas, que en todas ellas existen contextos en que estos verbos muestran propiedades intransitivas.

${ }_{92}$ Zwicky 1971, Cano Aguilar 1981: 207, Maldonado 1991: 48.

${ }^{93} \mathrm{Cf}$. Cameron 1998 para un estudio de esta alternancia en otros géneros discursivos.
} 


\subsubsection{Segmento 1 con verbo subordinante expreso}

En mis materiales, el verbo subordinante se halla expreso en 18 casos, que representan solo el 16,4\% (18/110) de los testimonios en que la marca de discurso directo es un verbo subordinante. ${ }^{94}$ En todos ellos, Loc 1 ha hecho una selección léxica concreta del vasto inventario de verbos que integran el área conceptual de la realización de actos lingüísticos: en términos generativistas, el verbum dicendi se halla expuesto en la estructura superficial.

Esta selección léxica resulta de la interpretación que Loc 1 hace del acto de habla de Loc 2 y que impone al destinatario, quien, en principio, no ha presenciado el acto verbal referido. Verbos como afirmar, advertir, pedir, asegurar, denunciar, revelar, acusar, admitir, ordenar o prometer añaden especificaciones al significado referencial del término superordenado: decir. La selección está determinada también por el comportamiento del verbo mismo, pues, como apunta Maingueneau, ${ }^{95}$ no todos los verbos que denotan un comportamiento verbal admiten configuraciones de discurso directo. Para las Academias, destacan entre ellos "unos pocos que aluden a la acción de presentar lo que se comunica de forma elaborada o reelaborada", 96 como contar, narrar, relatar, referir o explicar. Maldonado considera que en realidad se trata de verbos que exigen argumentos que recogen solamente el significado del enunciado y no la forma en que este fue emitido. ${ }^{97}$ Según esta misma autora, pueden emplearse en discurso directo, y no en indirecto, en cambio, los verbos que aluden a la cita de textos literarios (recitar, declamar) o de canciones (cantar, entonar), amén de aquellos que contienen un argumento implícito y significan 'decir algo' (maldecir, 'decir

\footnotetext{
${ }^{94}$ Estos casos integran apenas el 4,2\% (18/426) de los ejemplos en discurso directo marcado.

${ }^{95}$ Maingueneau 1981: 101.

${ }^{96}$ RAE y AALE 2009: §43.9o.

${ }^{97}$ Maldonado 1991: 56-57.
} 
maldiciones'; injuriar, 'decir palabras ofensivas'). Por último, añade que admiten tanto discurso directo como indirecto aquellos verbos que expresan opinión (opinar, considerar, juzgar), valoración positiva (alabar, aplaudir, elogiar), valoración negativa (criticar, reprochar, reprobar), orden o mandato (mandar, ordenar, encargar), petición o ruego (rogar, pedir, suplicar). Puesto que el objetivo de este trabajo no es resolver los no pocos problemas que plantea la selección léxica del discurso directo, remito al lector interesado a la bibliografía especializada. $^{98}$

El verbo subordinante explícito más abundante del corpus es, en cifras absolutas, el prototípico decir. Si bien es cierto que, en principio, la no-elisión de verbos de habla debe responder a la intención de Loc 1 de explicitar la fuerza ilocucionaria del acto de habla de Loc 2, en realidad se presentaron apenas 8 casos del verbo decir, frente a 10 testimonios de verbos más específicos y a 90 de verbos elididos. Puede decirse que, por su mínima incidencia, son atípicos los titulares en discurso directo con el verbo decir explícito.

(5) a. Mi popularidad sigue creciendo, dice Víctor González Torres [LAP 22/02/05: 32]

b. No agredimos a la Orcao, dicen zapatistas [JOR 7/01/09: 10]

c. Hoy nace una nueva Bolivia, dice Evo [UNI 23/01/10: A21]

d. Bienvenida la disciplina fiscal, dice la Asobancaria [тРо 23/01/10: 112]

e. Alejandro Sanz no es buen padre, afirma su ex Valeria Rivera [HOY 26/01/10: 2D]

f. Zelaya radicará en México, revelan [UNI 23/01/10: A22]

g. Gobiernos panistas tiran el dinero, acusa Beltrones [UNI 24/01/10: A6]

Como ha podido advertirse, todos los titulares de la serie (5), así como los ejemplos (2e), (3a) y (3b), responden a una misma estructura abstracta: el

\footnotetext{
${ }^{98}$ Por ejemplo, Kerbrat-Orecchioni 1980, Maingueneau 1981, Fónagy 1986, Maldonado 1991, Verdín Díaz 1970: 37-46, Delbecque y Lamiroy 1999, RAE y AALE 2009.
} 
segmento 2 precede segmento 1 , y ambos se encuentran separados gráficamente por medio de una coma, que señala, por ende, lo que Rivarola y Reisz de Rivarola denominan un "cambio de niveles discursivos". ${ }^{99}$

Se presentaron casos únicamente en tres diarios del corpus definitivo: $E l$ Universal (México), El Tiempo (Bogotá) y Hoy (Santo Domingo). No se registré ningún titular de este tipo en la prensa española, ni siquiera en los sucesivos corpus piloto. Con base en ello, puede decirse que se trata de un fenómeno propio de la prensa hispanoamericana, relativamente frecuente hacia la zona más septentrional. Debo añadir, sin embargo, que Hurtado cita algunos ejemplos del diario madrileño El País, pero admite que es un fenómeno mucho menos frecuente que en Hispanoamérica (al igual que la variedad léxica de verbos de habla empleados en estas construcciones). En su opinión, el fenómeno es particularmente típico de los encabezados colombianos, "hasta el punto de que se podría afirmar, incluso, que esta ordenación de los elementos de la cita dentro del titular casi se ha convertido en un cliché de la prensa de ese país". ${ }^{100}$

En los titulares de este tipo, donde el segmento 1 con verbo explícito sucede al segmento 2, el cambio de nivel discursivo siempre está marcado ortográficamente. El uso de comas con esa función se encuentra generalizado. ${ }^{101}$ Muy excepcionalmente se observan otros signos en secuencias de esta índole, pero difícilmente podrían considerarse usos normales en los encabezados periodísticos, pues su incidencia es mínima: ${ }^{102}$

\footnotetext{
${ }^{99}$ Rivarola y Reisz de Rivarola 1984: 164.

${ }^{100}$ Hurtado 2009: 197.

${ }^{101}$ De hecho, es lo que recomienda la influyente agencia informativa estadounidense AP (2003: 41-42).

${ }^{102}$ Las Academias censuran, por cierto, el uso de los dos puntos en casos como (6a): "Cuando las palabras reproducidas en discurso directo se anteponen al verbo de lengua o pensamiento, no se emplean los dos puntos, sino la coma o la raya, según los casos" (RAE y AALE 2010b: cap. III, §3.4.4.2.3).
} 
(6) a. El GDF quiere amedrentarnos: acusan vecinos [JOR 30/07/10: 33]

b. Exijan, critiquen — pide Patrón Laviada [YUC 02/08/01: 1]

Registro en la muestra cuantificada solamente un encabezado en discurso directo marcado donde un segmento 1 con verbo expreso antecede al segmento 2, el cual reproduzco en (7a). En todos los casos observados, los niveles discursivos están separados por medio de dos puntos. La presencia sistemática de esta construcción en los corpus piloto, particularmente en periódicos hispanoamericanos, permite descartar que se trate de un uso anómalo. Además se trata, como bien se sabe, de una estructura empleada con especial profusión en otros géneros discursivos:

(7) a. En Satélite insisten: no al Viaducto [UNI 21/01/10: A15]

b. Dice Bours: no firmo en blanco [REF 9/01/09: 4]

c. Admite la STPS: nadie cumple ni respeta la Ley Federal del Trabajo [JOR 21/02/05: 1]

\subsubsection{Segmento 1 con verbo subordinante elidido}

Un verbum dicendi elidido constituye la única marca de discurso directo en 92 casos de mi corpus, que representan el $83,6 \%$ del total de ejemplos donde la marca de discurso directo es un verbo subordinante $(92 / 110) .{ }^{103}$ Como afirma Moreno de Alba, la elisión del verbo constituye "un recurso al que recurren casi todos los diarios en la redacción de sus encabezamientos". ${ }^{104}$ Romero Álvarez advierte, por su parte, que esta práctica “cada vez es más frecuente en el lenguaje de los titulares de los periódicos" $" 105$ y acaso es así porque, a juicio de Hurtado,

\footnotetext{
${ }^{103}$ Estos testimonios representan el 21,6\% (92/426) de la suma de casos en discurso directo marcado.

${ }^{104}$ Moreno de Alba 1996: 45.

${ }^{105}$ Romero Álvarez 1990: 95. En su estudio sobre la evolución de los titulares de El Universal de México, Guízar describe un aumento significativo de este recurso a partir de 1980 (Guízar 2007: 103).
} 
"con ello se logran titulares más ágiles, dramáticos y directos". 106 Según Fernández Lagunilla y Pendones, esta solución "se encuentra con más frecuencia en las secciones dedicadas a temas políticos". ${ }^{107}$

Gutiérrez Ordóñez apunta que, en los titulares en discurso directo, la elipsis se efectúa únicamente cuando se trata de "verbos semánticamente no marcados frente a aquellos otros que hacen referencia a un tipo de acto de habla concreto". ${ }^{108}$ Esto permite, desde luego, su fácil reconstrucción. ${ }^{109}$ La omisión de verbos de fácil recuperación y más bien inespecíficos se debe, obviamente, a la tensión entre interés ${ }^{110}$ y relevancia ${ }^{111}$ a que está sujeta la enunciación de encabezados periodísticos, la cual, como se sabe, busca un equilibrio entre economía e informatividad. ${ }^{112}$

Como marcas de elipsis de verbo de habla, los titulares de la prensa hispánica presentan casi siempre el uso de los dos puntos. Gracias a este procedimiento, con el que en ocasiones se economiza también algún utensilio gramatical, se produce un tipo de bimembración expresiva, es decir, el proceso que, de acuerdo con Alarcos, ${ }^{113}$ genera una configuración lingüística donde tema y rema se hallan separados. ${ }^{114}$ Se trata, sin duda alguna, de un rasgo típico del discurso de los titulares: "Esa partición en dos segmentos de la secuencia no se daría en otras situaciones de habla". ${ }^{115}$

\footnotetext{
${ }^{106}$ Hurtado 2009: 198.

${ }^{107}$ Fernández Lagunilla y Pendones 1997: 87.

${ }^{108}$ Gutiérrez Ordóñez 1986: 28.

${ }^{109}$ Romero Álvarez 1990: 95; cf. Perfetti et al. 1987, Hurtado 2003: 57.

${ }^{110}$ Leech 1983: 47.

${ }^{111}$ Grice 1975: 47.

112 Thogmartin 1991: 251-252.

${ }^{113}$ Alarcos 1977: 146.

${ }^{114}$ En estos casos, el rema corresponde al presunto enunciado secundario, y el tema, al apelativo que aluda a Loc 2. En ocasiones, ciertamente escasas, el tema incluye también la mención del destinatario y las circunstancias de la enunciación secundaria.

${ }^{115}$ Alarcos 1977: 142; $c f$. Hernando Cuadrado 2002: 265.
} 
El 58,7\% de los encabezados con verbo subordinante elidido (54/92) presenta un orden de constituyentes S2-S1. Todos los casos contabilizados se presentaron en los periódicos El Tiempo, La Opinión y, sobre todo, El Universal. La marca ortográfica utilizada para indicar el cambio de nivel discursivo fue siempre dos puntos (:). Algún periódico del ámbito hispánico —el mexicano Reformaemplea para ello punto y guion (.-), como sucede en ciertos casos del periodismo anglófono estadounidense. ${ }^{116}$ En (8a-8e) transcribo algunos ejemplos de discurso directo marcado con orden $\mathrm{S} 2-\mathrm{S} 1$ y dos puntos como marca de elipsis de verbo de habla, y en (8f), un caso con punto y guion.

(8) a. No pienso aplazar elecciones: Presidente [тРо 19/01/10: 1-3]

b. Sí, queremos derrocar a los caciques: Ortega [UNI 21/01/10: A6]

c. MESSI ES SUPERIOR A CRISTIANO: MARADONA [OPI 22/01/10: 2C]

d. No estoy trabajando para mí: Córdova [UNi 18/01/10: A19\}

e. Troncal de TransMilenio por la 26 no estará a tiempo: contratista [ТРО 22/01/10: 1-12]

f. La moral de la Iglesia ha caducado.- Maza [REF 10/01/09: CULT 5]

El ejemplo (8a) reproduce una declaración del presidente de Colombia, Álvaro Uribe; (8b), una de Jesús Ortega, líder nacional del mexicano Partido de la Revolución Democrática; (8c), del ex futbolista argentino Diego Armando Maradona; (8d), del Secretario de Salud de México; (8e) del representante legal de la compañía que construye una ruta de autobuses confinados en Bogotá; (8f) del periodista texano y sacerdote jesuita Enrique Maza. En todos ellos se sobreentiende la existencia de un verbo de habla inespecífico, como decir.

\footnotetext{
${ }^{116}$ Se ha empleado también la raya (-) en el periodismo estadounidense, según reportan Garst y Bernstein (1940: 136). Anotan este ejemplo con orden S2-S1: DEMOCRATS WILL WIN IN THE FALL-JONES.
} 
El restante $41,3 \%$ de titulares con verbo subordinante elidido (38/92) presenta el orden de constituyentes inverso: el segmento 1 precede al segmento 2. Es decir, en ellos la representación de las palabras ajenas sucede a la alusión a Loc 1 . He aquí algunos ejemplos:

(9) a. Chávez: Hay que racionar para impedir el colapso eléctrico [ELN 18/01/10: A1]

b. Lula: la izquierda debe unirse para evitar lo de Chile [CLA 23/01/10: 46]

c. Preval: estamos en el proceso de recuperar el control [HOY 22/01/10: 11B]

d. Santiago Creel: sí, voy por la Presidencia [Uni 23/01/10: A5]

e. Procomer: exportaciones cayeron un 9\% en el 2009 [LAN 23/01/10: $20 \mathrm{~A}]$

Puede verse que, en todos estos casos — donde la única marca de discurso directo es un segmento subordinante con verbo de habla elidido-, es ligeramente menor la frecuencia relativa de uso de las estructuras con orden de constituyentes S1-S2 que de S2-S1. Si bien el orden S1-S2 es menos abundante en el corpus, también es cierto que se presenta en un mayor número de periódicos: Clarín, El Comercio, El Nacional, El Universal, Hoy y La Nación. De todos ellos, el único que alterna en sus planas el uso de ambas ordenaciones es el mexicano $E l$ Universal. No registré testimonios de ninguna de ellas en el diario chileno $\mathrm{El}$ Mercurio. Para S1-S2, el índice gráfico de elipsis verbal es, invariablemente, dos puntos en todos los diarios que presentan esta disposición, incluidos todos los casos de los corpus piloto.

Solo me resta suscribir, por último, la observación de Hurtado ${ }^{117}$ de que es menos frecuente en España que en algunas zonas de Hispanoamérica (particularmente en México, Colombia y Chile, añado yo) la alusión a Loc 2 por medio de nombres comunes en titulares en discurso directo marcado con verbo elidido, ya

${ }^{117}$ Hurtado 2009: 200. 
sea con ordenación S1-S2 o S2-S1 (en realidad, la disposición S2-S1 en estructuras elípticas es prácticamente una desconocida en las planas de los diarios peninsulares, pero no la disposición S1-S2 en las de los periódicos hispanoamericanos).

\subsubsection{Marcas ortográficas}

A falta de información suprasegmental y extraverbal, la enunciación escrita ${ }^{118}$ exige, como se sabe, índices gráficos para explicitar determinadas instrucciones interpretativas, aplicables a la letra, la palabra, el sintagma o el texto. ${ }^{119} \mathrm{En} \mathrm{su}$ clasificación de la ortografía sintagmática, Catach incluye lo que ella denomina "signos de enunciación", ${ }^{20}$ es decir, todos aquellos que, en el discurso ajeno escrito, marcan un distanciamiento entre los locutores, o los puntos de vista, presentes en las enunciaciones de Loc 1 o Loc $2 .{ }^{121}$ Poseen dicho valor, por ejemplo, algunos usos de comillas, rayas, paréntesis y corchetes. ${ }^{122}$

Para algunos autores, el discurso directo marcado se restringe al discurso ajeno "introducido por algún signo gráfico en el texto: guiones, comillas, cursiva". ${ }^{123}$ Debe recordarse, sin embargo, que nos hemos apegado ${ }^{124}$ a la ya consagrada definición de marca como elemento lingüístico que, ante dos elementos comparables, añade cierta complejidad a uno de ellos. ${ }^{125}$ Evidentemente, los signos ortográficos de enunciación complican la estructura sintáctica y semántica

\footnotetext{
${ }^{118}$ Benveniste (1974) 2002: 9.

${ }^{119}$ Polo 1974: $\$ \S 6.0 .1$ y 7.2.3.

${ }^{120}$ Catach 1980: 22.

${ }^{121} C f$. Leech y Short 1981: 322, Maingueneau 1981: 106, Rivarola y Reisz de Rivarola 1984: 156-157, Collins 2001: 4.

${ }^{122}$ Desde luego, como bien aclara Verdín Díaz (1970: 141), "no es necesario que haya verbo introductor para que haya estilo directo".

${ }^{123}$ Sánchez-Rey 1991: 131.

${ }^{124}$ Para los discursos directo e indirecto.

${ }^{125}$ Givón 1995: 28.
} 
del enunciado; pero, como ya hemos visto, no son los únicos elementos lingüísticos que pueden hacerlo.

En mi corpus, los índices gráficos constituyen los únicos indicios formales de discurso directo en el 58,2\% (248/426) del total de casos de discurso directo marcado. Son, pues, la marca más abundante. Registro solamente comillas: ya inglesas (“" ), ya simples (“’), ya latinas o angulares («»).

He agrupado bajo (10) varios ejemplos de titulares que ostentan comillas inglesas como marca de discurso directo. En la serie (12) se encuentran algunos encabezados donde tal oficio es desempeñado por comillas simples. En (11) reproduzco el único caso de comillas angulares.

(10) a. "Yo quiero jugar" [CLA 23/01/10: E6]

b. "Mi modelo será empoderar a los ministros para que sientan el respaldo del Presidente" [MER 24/01/10: A1]

c. "Para nosotros ya son un hijo más" [ELP 24/01/10: 5]

d. "Aún me duele el alma cuando recuerdo los gritos de mi hija" [HOY 23/01/10: 4A]

e. "No tengo nada que repetir" [COM 23/01/10: A11]

f. "Quiero ver a Colombia desde el espacio" [тРо 19/01/10: 1-1]

g. "El sistema de justicia ha sido rebasado" [UNI 20/01/10: A19]

h. "No soy el Mesías de nada, difundo una labor musical" [ELN 19/01/10: D4]

(11) «Quien dirija una radio tiene el derecho de manejarla como crea conveniente» [ELN 18/01/10: D3]

(12) а. 'No soy Dios, soy Cristo eterno' [тРо 19/01/10: 1-7]

b. 'Viene mi gobierno, no el de Arias' [LAN 21/01/10: 1A]

c. 'Es un juego más' [OPI 20/01/10: 4C]

En términos absolutos, las comillas inglesas son la marca más abundante, con el $76,6 \%$ de todos los casos de discurso directo marcado ortográficamente (190/248); el 23\% (57/248) corresponde a las comillas simples y apenas el 0,4\% (1/248) a las angulares. Es evidente que, al menos en los titulares de las 
publicaciones periódicas hispánicas, el uso de las comillas angulares está en claro retroceso. ${ }^{126}$ Es probable que la motivación principal sea de índole netamente económica, pues estas comillas ocupan un espacio mayor que las demás (mínimo si se quiere, pero significativo al preparar el formato de las planas). Esto explicaría asimismo el cada vez más frecuente uso de las comillas simples. Es por ello también que rotativos como La Nación y El Nacional alternan en el uso de comillas - el primero entre inglesas y simples y el segundo entre angulares e inglesas- con una marcada preferencia en ambos casos por el signo tipográficamente más pequeño. Registro solamente comillas inglesas en los titulares en discurso directo de los diarios Clarín, El Comercio, El Mercurio, El País, El Universal y Hoy. Los periódicos El Tiempo y La Opinión no emplean más que comillas simples en sus encabezados. ${ }^{127}$

Ya hemos dicho que la mayoría de los titulares en discurso directo marcado —el 58,2\% (248/426) — presenta únicamente marcas ortográficas. La variación por diario es, sin embargo, notable: si bien la media aritmética -60,1\%— es similar a esa cifra, las frecuencias relativas de uso son muy heterogéneas, pues van del 7\% (7/94) en el diario mexicano El Universal al 90\% (43/48) en el periódico español El País. Además de El Universal, presentan incidencias notablemente inferiores a la media - menores que el 40\% — La Opinión y Hoy. Además de en El País, registro frecuencias de uso significativamente superiores a la media —mayores que el 80\%- en El Comercio, Clarín, La Nación y El Tiempo. Los valores de El Nacional y El Mercurio son casi idénticos a la media. Puede deducirse, por tanto, que en los periódicos de América del Norte y del Caribe se

\footnotetext{
${ }^{126}$ Debo aclarar, sin embargo, que algunos diarios, como los españoles El Mundo, Abc y Público - no contabilizados para las frecuencias de uso, pero sí presentes en los corpus piloto-, utilizan estas comillas de manera casi sistemática en sus páginas. Con todo, no parecen ser sino casos aislados dentro del vasto universo de la prensa hispánica.

${ }^{127}$ No deja de sorprender, pues, Rebollo Torío (2008: 174) cuando asevera que en este asunto "no hay criterios determinados que permitan establecer una unificación".
} 
tiende a preferir otras formas de marcar la supuesta retransmisión directa de las palabras ajenas.

En esta variedad del discurso ajeno, que Récanati denomina "cita abierta", ${ }^{128}$ la información provista por el texto no suele ser suficiente para saber quién es el locutor secundario: no hay mención alguna a Loc 2, ni determinada ni indeterminada, motivo que ha llevado a autores como Escribano Hernández a emplear el término "cita directa sin sujeto". ${ }^{129}$ Loc 1 tampoco propone una interpretación del acto de habla de Loc 2, por cuanto no hay verbos de habla expresos. ${ }^{130}$ Es por estas razones que Fernández Lagunilla y Pendones ${ }^{131}$ sostienen que es esta la "forma más directa de introducir un enunciado reproducido en un título". Si bien es cierto que la omisión de Loc 2 en el texto apunta a una retransmisión más directa que en las otras variedades de discurso directo marcado, hay que tener en cuenta que las marcas ortográficas -en nuestros casos, comillas simples, inglesas o angulares-indican explícitamente la existencia de una retransmisión. ${ }^{132}$ Veremos más adelante que esto no sucede en los casos de discurso directo no marcado, que constituye, por ende, la variedad más directa del discurso ajeno en los titulares.

\footnotetext{
${ }^{128}$ Récanati 2001.

${ }^{129}$ Escribano Hernández 2007: 67.

${ }^{130} C f$. Haverkate 1996: 99. Con base en la ausencia de verbo subordinante en esta modalidad de discurso directo, Rivarola y Reisz de Rivarola (1984: 159) proponen asignarle el apelativo "discurso directo no-regido", ya que, "mantiene como única señal de su carácter de discurso referido e insertado como un cuerpo extraño en el discurso que lo refiere, la "entonación por diferenciación' [...] en el caso de la lengua hablada y la sola presencia de signos gráficos como comillas o guiones en el caso de la lengua escrita".

${ }^{131}$ Fernández Lagunilla y Pendones 1997: 86.

${ }^{132}$ Por este motivo, dice Waugh (1995: 138-139), su presencia en el discurso periodístico es notabilísima.
} 


\subsubsection{Doble marca}

En el $16 \%$ del total de encabezados en discurso directo marcado (68/424), la supuesta retransmisión directa está indicada por una marca doble: un verbo subordinante - ya sea expreso o elidido- y algún índice gráfico. Recojo testimonios en todos los diarios considerados para el análisis cuantitativo. En la gran mayoría de los casos —el 94,1\% (64/68)—, la marca ortográfica afecta a todo el segmento 2, como sucede en los ejemplos siguientes:

(13) a. Aníbal Fernández amenaza: "Redrado no entra más al Central" [CLA 23/01/10: 1]

b. Evo Morales: "Estados Unidos fue mi mejor jefe de campaña" [ELN 23/01/10: A11]

c. Napolitano: "Washington no exige escáneres corporales" [ELP 22/01/10: 10]

d. Rodrigo Arias: 'Desmentiré ese montón de sandeces' [LAN 21/01/10: $5 \mathrm{~A}]$

e. Ricardo Lagos: "Haremos oposición con grandeza" [MER 18/01/10: A1]

f. Pared Pérez: "No hay tiempo para aprobar ley de partidos" [HOY 18/01/10: 14A]

g. Bayly: "Si todo va bien, me inscribiré en diciembre" [COM 19/01/10: C6]

(14) a. 'Uribe se bajó los pantalones', dice Chávez [TPO 18/01/10: 1-7]

b. "Era estar vivo en una tumba", relatan rescatados de las ruinas en Puerto Príncipe [MER 19/01/10: A4]

c. 'Neville es un tarado', dice Tevez [OPI 22/01/10 2C]

d. "Aún no hemos terminado": Sánchez [UNI 18/01/10: D7]

En estos encabezados se observan nuevamente los órdenes de constituyentes S1S2 y S2-S1 (al igual que en los casos donde un verbo de habla elidido o explícito constituye la única marca de discurso directo). Aquí es más frecuente la elipsis verbal en el orden S1-S2 que en S2-S1. Reproduzco en (13) algunos titulares con 
orden S1-S2, y, en (14), con orden S2-S1. Puede verse que en (13a), (14a), (14b) y (14c), los verba dicendi no están elididos.

Las frecuencias de uso de las ordenaciones S1-S2 y S2-S1 se invierten cuando el discurso directo está doblemente marcado: a diferencia de los encabezados de discurso directo marcado con verbo de habla pero sin comillas, aquí el orden de constituyentes S1-S2 —es decir, el que se observa en la serie (13) - es poderosamente dominante. Esta disposición alcanza el 89,1\% (57/64), mientras que el orden S2-S1 —ejemplificado en (14) — apenas llega aquí al 10,9\% restante (7/64).

El orden S1-S2 se presenta en todos los periódicos, salvo en La Opinión y El Tiempo. En cambio, se acude únicamente al orden inverso en El Mercurio, El Universal, El Tiempo y La Opinión. Puede deducirse que solo El Universal y El Mercurio emplean ambas disposiciones. El comportamiento del rotativo mexicano es el mismo que en el discurso directo solamente marcado por algún verbo de habla. En cuanto al periódico chileno -el cual por cierto acapara la mayor parte de testimonios de discurso directo doblemente marcado-, es preciso recordar que no emplea formas de discurso directo sin comillas.

No registro casos de comillas angulares como parte de la marca doble del discurso directo en la muestra cuantificada, pero evidentemente existen en el vasto universo de estudio (baste mencionar diarios como los madrileños $E l$ Mundo, Abc y Público, por ejemplo). Siempre más abundantes que las demás, las comillas inglesas no alternan con las simples en los mismos periódicos cuando funcionan como parte de la doble marca (al menos no en mis materiales). No emplean comillas inglesas, y por tanto únicamente simples, los diarios $\mathrm{La}$ Nación, El Tiempo y La Opinión. Asistimos al uso de comillas simples en los 
ejemplos (13d), (14a) y (14c), y al de inglesas en (13a)-(13c), (13e)-(13g), (14b) y (14d).

En muy pocos encabezados — todos de El Universal—, la marca ortográfica no afecta a todo el segmento 2, sino solo a algún constituyente de este. Relativamente usual en la prensa mexicana, dicho fenómeno en ocasiones presenta como variante el empleo de letras cursivas, que, de acuerdo con Polo, ${ }^{133}$ también forman parte del dominio de la ortografía sintagmática, la cual estudia, como bien se sabe, los diversos procedimientos gráficos que afectan la interpretación de palabras solas o sintagmas completos. El periódico mexicano La Jornada — considerado en el corpus piloto- ofrece abundantes ejemplos de ello.

(15) a. Sólo es una "cortina de humo", dice López Obrador [UNI 23/01/10: A4]

b. Alianza PAN-PRD, un "engendro": Beltrones [UNi 20/01/10: A9]

c. "Parche fiscal" desvía capitales: AmCham [UNI 20/01/10: A1]

d. Víctor González Torres: gastaré mi dinero en el "partido del pueblo" [LAP 23/02/05: 34]

e. Aunque le incomode, Fox no me hará a un lado, señala López Obrador [JOR 26/02/05: 9]

Retomo de mi corpus piloto los ejemplos (15d) y (15e) para, en el último caso, ejemplificar el uso de cursivas con el valor mencionado, $\mathrm{y}$, en el anterior, para constatar que la marca ortográfica sobre un constituyente también se utiliza en titulares con orden de constituyentes S1-S2. Los tres primeros encabezados proceden de la muestra cuantificada.

Quedan descartados los posibles usos de estos diacríticos como índices de simple empleo metalingüístico por cuanto no es posible anteponer a los segmentos marcados secuencias como la expresión, la palabra, la frase, etcétera (por

${ }^{133}$ Polo 1974: §6.0.1. 
ejemplo, *La expresión "parche fiscal" desvía capitales). Por consiguiente, y dada la naturaleza redundante de la marca doble, parece claro que la finalidad que anima a este tipo de construcciones es la de enfatizar la supuesta literalidad de S2, habida cuenta de la inexactitud de las citas directas en los textos periodísticos. ${ }^{134}$ La necesidad de énfasis se explica, a su vez, por las exigencias de credibilidad del texto periodístico, ${ }^{135}$ en el cual, como dirían Clark y Gerrig, ${ }^{136}$ con la inclusión de representaciones selectivas se pretende demostrar la existencia de referentes. ${ }^{137}$

Hemos dicho ya que la interpretación de la cita directa como copia rigurosamente literal responde a una "ley del discurso"" 138 y que, por tanto, no tiene por qué existir correspondencia exacta en el sentido contextual. Ni siquiera en el caso de marcas redundantes. Como afirma Reyes, "las comillas no son lacres que garanticen la integridad del texto trasladado, son solamente señales de aislamiento, el escalón hacia otro nivel del texto". ${ }^{139}$

Los titulares periodísticos revelan, pues, que es posible hablar de grados en la indicación de la supuesta literalidad del discurso directo. ${ }^{140}$ Claro está, al menos en los casos que he estudiado, que esta posibilidad no se debe sino a la intención de Loc 1 de insuflar veracidad al enunciado y, también, de destacar, por razones semántico-pragmáticas, algún constituyente. Es necesario insistir en que solo se

\footnotetext{
${ }^{134}$ Basado únicamente en ejemplos de español literario, Verdín Díaz considera extraños los casos de discurso directo doblemente marcados y atribuye su existencia a la intención simple autoral de llamar la atención sobre determinadas palabras para evitar que el lector las pase por alto, "sin darles la fuerza y trascendencia significativa que realmente tienen": por cuanto "el estilo directo se presenta de una manera tan clara [...] que resulta un poco extraño encontrar ejemplos de estilo directo señalados por comillas [..., el autor] recurre al empleo de comillas para llamarle [al lector] de manera abierta la atención" (Verdín Díaz 1970: 41).

${ }^{135}$ Romero Álvarez 2000. Cf. Van Dijk (1980) 1990: 130.

${ }^{136}$ Clark y Gerrig 1990.

${ }^{137}$ Cf. Fónagy 1986: 255, Haverkate 1996: 100, Vincent y Perrin 1999: 291-313.

${ }^{138}$ Maingueneau 1981: 99.

${ }^{139}$ Reyes 1984: 39.

${ }^{140} C f$. RAE y AALE 2009 : $\$ 43.9 \mathrm{e}$.
} 
trata de grados en la indicación de literalidad, y no necesariamente de literalidad efectiva, a pesar de que las citas textuales puedan conllevar responsabilidades legales para el periodista. A fin de ilustrarlo, retomo del corpus piloto el siguiente titular y parte de su contexto lingüístico:

(16) Me propusieron panistas negociar el desafuero y "dije no": López Obrador [JOR 22/02/05: 1]

Un reportero le preguntó [a López Obrador]: “¿Es cierto que a usted o a su defensa se le habría propuesto negociar el desafuero a cambio de responsabilizar a Ortiz Pinchetti, y que incluso el vicecoordinador de la fracción del PAN en la Cámara de Diputados, Germán Martínez, habría reconocido que si lo desaforaran enfrentarían un grave problema los propios panistas?"

López Obrador dijo: "Ah, sí, ya; es cierto y dijimos no. Ya". [JOR 22/02/05: 5]

El titular presenta el orden de constituyentes S2-S1 y los dos puntos señalan la elipsis del verbo de habla subordinante. El segmento 2 contiene, además, deícticos de primera persona que inequívocamente señalan a un Loc 2 -no coincidente con Loc 1 - como su responsable. Estas particularidades son, como hemos dicho, más que suficientes para hablar de discurso directo y, por tanto, de una supuesta retransmisión literal. Loc 1, sin embargo, entrecomilla la oración coordinada, con lo cual enfatiza el carácter literal de ese constituyente en particular. Un simple cotejo con el contexto lingüístico permite comprobar que ni siquiera es estrictamente literal el segmento sobre el cual recae la doble marca (asumiendo el ya dudoso caso de que el relato encabezado por dicho titular contenga una transcripción verdaderamente literal de las palabras de Loc 2).

Toda marca de discurso ajeno establece cierta distancia entre Loc 1 y el enunciado o la enunciación de Loc $2 .{ }^{141}$ En el discurso directo marcado, Loc 1

${ }^{141} C f$. Chafe (1986) para abundar en el tema de la evidencialidad en general, y Li (1986) y Sakita (2002) para su estudio en el discurso ajeno. 
trata de señalar que el enunciado secundario no pertenece a su registro lingüístico o que no coincide con su punto de vista. Con las comillas, dice acertadamente Maingueneau, ${ }^{142}$ el locutor aísla fragmentos de textos de otros para señalar que no son de su autoría y, además, para hacer notar que no comparte el punto de vista del autor verdadero.

Las comillas y las letras cursivas desempeñan una función demarcativa. ${ }^{143} \mathrm{El}$ locutor se vale de ella, en principio, para determinar un espacio intertextual, ${ }^{144}$ es decir, para señalar que un segmento pertenece al discurso de otro hablante. Secundariamente, pueden funcionar como marcas de condescendencia, ${ }^{145}$ esto es, pueden indicar que se pone en evidencia a un Loc 2 oponente, cuyas palabras son reproducidas de manera irónica. ${ }^{146}$ Retomaré este problema más adelante.

\subsection{Discurso directo no marcado}

Puede decirse que la tradición gramatical se ha ocupado básicamente de las características de lo que aquí llamo discursos directo e indirecto marcados: no son pocos los estudiosos que solo toman en cuenta estas dos variedades para caracterizar el discurso ajeno. ${ }^{147}$ Desde que se popularizó el término estilo indirecto libre, acuñado por Bally, ${ }^{148}$ diversos autores han añadido una tercera variedad que combina propiedades - casi siempre sintácticas- de las dos

\footnotetext{
${ }^{142}$ Maingueneau 1981: 108.

${ }^{143}$ Authier 1981.

${ }^{144}$ Fernández Lagunilla y Pendones 1993.

${ }^{145}$ Ibid.

${ }^{146}$ Fernández Lagunilla y Pendones (1993) identifican otras funciones desempeñadas por las comillas: indicación de lenguaje figurado, de énfasis, de usos aproximados, de registros lingüísticos diferentes. $C f$. Cappelen y Lepore (1997) para más detalles de la función metalingüística del discurso directo.

${ }^{147}$ R AE (1931) 1962: §382, Gili Gaya 1967 §219.II, Partee 1973, Comrie 1986, Li 1986, Hand 1991, entre muchos otros.

${ }^{148}$ Bally 1912.
} 
variedades hasta entonces descritas. ${ }^{149}$ Debido a las ambiguas definiciones y a la falta de consenso en las propuestas de clasificación, el "estilo indirecto libre" se ha convertido en una cómoda categoría donde, de manera confusa y desordenada, se agrupan todas las formas de reproducción discursiva que no se ajustan estrictamente a los patrones estereotipados de los discursos marcados. ${ }^{150}$

No recurriré aquí a la arraigada categorización tripartita del discurso referido por cuanto resulta muy limitada para caracterizar los titulares periodísticos: en primer lugar, excluye las variedades que no implican reproducción discursiva, y en segundo, suele confundir en una misma categoría variedades del discurso ajeno que presentan características formales y funcionales diversas. ${ }^{151}$ Como veremos más adelante, la mayoría de los titulares periodísticos con discurso ajeno se ubica en alguna de estas dos áreas.

He clasificado las formas no marcadas - aquellas que carecen de indicaciones explícitas de una reproducción discursiva- con base en el eje deíctico evidenciado por el texto: estamos ante discurso directo no marcado cuando Loc 1 retiene, en su enunciado, el sistema deíctico de Loc 2, y ante discurso indirecto no marcado cuando Loc 1 adapta los deícticos del supuesto enunciado de Loc 2 a

\footnotetext{
149 Jespersen (1924) 1968: 349, Genette (1972) 1989: 231, Todorov (1972) 2000: 347-348, Banfield 1973: 10-13, RAE 1973: §3.19.4b, Wierzbicka 1974: 294-297, Alcina y Blecua (1975) 2001: §8.4.1.1, entre otros. Según Coulmas (1986 6-10), ya hablaban de "formas mezcladas" Tobler, en 1894, y Kalepky, en 1899 ( $c f$. Voloshinov [1929] 1992: 187-191 y Verdín Díaz 1970: 9-16).

${ }^{150}$ Con relativa frecuencia, el "estilo indirecto libre" se asocia con las diversas técnicas de que el lenguaje literario, o con intención literaria, echa mano para representar situaciones cercanas al monólogo interior. Reyes (1994a: 610), por ejemplo, afirma que se trata exclusivamente de un "fenómeno del lenguaje literario", consistente en una "traslación de discurso sui generis, que presenta los contenidos de la conciencia de un personaje". Al margen de que esta no es una idea que goce de total aceptación entre los especialistas, parece evidenciar, una vez más, que es necesario sustentar las generalizaciones gramaticales en materiales que reúnan diversos usos discursivos.

${ }^{151}$ Más adelante volveré a este problema.
} 
su propia situación enunciativa. ${ }^{152}$ En las siguientes líneas, expongo únicamente las características del discurso directo no marcado: no será sino en el siguiente capítulo donde aborde las diversas variedades de discurso indirecto que presenta mi corpus.

El supuesto de la retención deíctica como rasgo más importante del discurso directo $^{153}$ explica, pues, el criterio aquí seguido para considerar como variedades de este a todos los enunciados donde el sistema de referencias situacionales de Loc 2 se conserva. Hablamos de discurso directo no marcado cuando los enunciados no ostentan indicaciones explícitas de una supuesta reproducción textual. En estos casos, la información que permite interpretar el enunciado como discurso ajeno no se halla en el texto, sino en el contexto.

En fechas relativamente recientes, algunos autores han advertido, con muy diversas denominaciones, la presencia de formas de discurso directo carentes de marcas. ${ }^{154}$ Lo usual en estos trabajos, sin embargo, es limitarse a señalar, de manera muy tangencial, su existencia. Al respecto, interesante resulta examinar la evolución reciente de la doctrina académica: en 1931, la Gramática no hablaba más que de algunas de las formas marcadas de los discursos directo e indirecto, que denominaba "estilo directo y estilo indirecto", ${ }^{155}$ y el Esbozo, de 1973, incorporó el "estilo indirecto libre" casi en los mismos términos que hizo Gili Gaya en su Curso, con lo cual la Real Academia adoptó la pauta trazada por Bally en 1912, unos sesenta años antes: esta modalidad del discurso ajeno se

\footnotetext{
${ }^{152}$ Cf. Hickmann 1993: 71.

${ }^{153}$ Coulmas 1986: 2 y 1994: 3553, Reyes 1993: 15 y 1994a: 592, Vicente Mateu 1994: 117-118, Van der Houwen 2000: 28, entre otros; $c f$. Vandelanotte 2004, Nølke, Fløttum y Norén 2004: 73-77.

${ }^{154}$ Chatman (1978) 1990: 216, Leech y Short, 1981: 322-323, Rivarola y Reisz de Rivarola 1984: 159, Fairclough 1988: 126, Reisz de Rivarola 1988: 146, Wales 1989: 189-198, Hickmann 1993: 70, Waugh 1995: 143, Collins 2001: 92, Nølke, Fløttum y Norén 2004: 61; $c f$. Page 1973, Short 1988, Longacre 1994, Mathis y Yule 1994.

${ }^{155}$ RAE (1931) 1962: §382.
} 
emplea —decían - para "incorporar al relato construcciones propias del estilo directo, conservando la viveza de este en exclamaciones, interrogaciones y demás elementos expresivos, pero sometiéndolos a los cambios de persona, tiempo, etc., necesarios en estilo indirecto". ${ }^{156}$ Para 2009, y estableciendo un paralelismo ${ }^{157}$ con lo que ahora denominan "discurso indirecto libre" y que definen a partir de una alternancia entre los ejes deícticos de Loc 1 y Loc 2, las Academias añaden el "discurso directo libre":

El DISCURSO DIRECTO LIBRE se caracteriza por la ausencia de verbos de lengua o de pensamiento, así como de otras marcas lingüísticas que separen el texto que corresponde al narrador del que pertenece a los personajes [...]. Aun así, los escritores usan a menudo signos ortográficos para marcar esa transición ${ }^{158}$

Si bien constituye un notable avance para la doctrina académica la incorporación de variedades del discurso directo carentes marcas indicadoras de un cambio de nivel discursivo, esta definición no está libre de serios problemas conceptuales: aunque parezca obvio, en ningún caso los signos ortográficos pueden ser de índole no lingüística, tal como sugieren las Academias al decir que, sin marcas lingüísticas, algunos autores marcan la transición con signos ortográficos. Admitir eso implicaría admitir también que la lingüística no se ocupa de la enunciación escrita y sus problemas, posición por lo demás insostenible en quien asimismo se propone fijar normas ortográficas. ${ }^{159}$ Además, si aunado a la pretensión de literalidad y su concomitante anclaje deíctico en Loc 2, el único rasgo distintivo fuera la ausencia de verbo subordinante - lo cual supondría referirse a lo que Rivarola y Reisz de Rivarola denominan "discurso directo noregido" 160 - no sería siquiera pertinente hablar de marcas lingüísticas -y

\footnotetext{
${ }^{156}$ RAE 1973: §3.19.4.A.

${ }^{157}$ Situación rechazada años antes por Reyes (1984: 147).

${ }^{158}$ RAE y AALE 2009: \$43.9d.

${ }^{159}$ RAE y AALE 2010 b.

${ }^{160}$ Rivarola y Reisz de Rivarola 1984: 159. Cf. Haverkate 1996: 99.
} 
mucho menos de "otras marcas lingüísticas"-, cuya ausencia parece determinar el carácter "libre" de una variedad del discurso directo.

A la luz de investigaciones como la presente, tal vez convendría matizar la también aseveración académica de que esta modalidad del discurso ajeno es propia del discurso literario. ${ }^{161}$ Según Maldonado, el discurso directo no marcado, que ella denomina "discurso directo libre propiamente dicho", es "exclusivo de la lengua escrita". ${ }^{162}$ Esto se debe — añade- a que el oyente no es capaz de percibir la reproducción de las palabras ajenas si el hablante no las diferencia formalmente de las propias, por lo que el receptor atribuye todo el discurso al emisor. En realidad, ante una ausencia absoluta de marcas formales, solo es posible detectar la retransmisión a partir de datos contextuales y situacionales, ya sea en lo oral o en lo escrito, que no siempre están al alcance del destinatario. Aunque es evidente que esto dificulta el trabajo del analista, todos hemos comprobado que muchos hablantes acostumbran apropiarse de las palabras ajenas, independientemente del género discursivo o de si se asiste a enunciaciones escritas u orales.

(17) a. Yo también cantaré [COM 19/01/10: C12]

b. ¡YO LE GANO! [LAP 24/02/05: 1]

c. Seré el próximo gobernador [UNI 27/02/05: A23]

d. Ministra, no digas que fue un sueño [A ВC 11/01/09: 6]

e. ¡NO ME CALLARÁ! [LAP 23/02/05: 1]

f. Mejor sigamos con el modelo [COM 24/01/10: A22]

En la serie (17) reproduzco varios ejemplos en encabezados. En todos ellos, al igual que en los demás casos de formas no marcadas, la interpretación del titular como discurso ajeno no puede conseguirse sino por medio de información contextual: leídos estos enunciados de manera aislada, en principio serán

\footnotetext{
${ }^{161}$ RAE y AALE 2009: $\$ 43.9 d$.

162 Maldonado 1999: 3552.
} 
probablemente atribuidos solo al periodista o a su organización informativa. Si bien en algunas ocasiones la contigüidad de fotografías de Loc 2 permite inferir la existencia de una retransmisión directa, a menudo solamente puede hacerse gracias a comparaciones intertextuales, es decir, confrontando el texto del encabezado con el de la nota informativa. Es por ello que a continuación retomo dos de los titulares anteriores junto con fragmentos de los textos que encabezan:

(17e) ¡NO ME CALLARÁ! [LAP 23/02/05: 1]

El Presidente Vicente Fox actúa con "mucha irresponsabilidad y de manera autoritaria", declaró Andrés Manuel López Obrador, y advirtió que no lo van a silenciar y se defenderá aunque saquen un boletín diario de Los Pinos. [LAP 23/02/05: 3]

(17f) Mejor sigamos con el modelo [COM 24/01/10: A22]

"Si la alternativa es un modelo económico como el de Argentina, Bolivia o Venezuela, en el que la intervención estatal afecta la economía, es mejor quedarse como estamos." [COM 24/01/10: A22]

En el testimonio (17e) se representan ciertas palabras del ex candidato a la presidencia de México Andrés Manuel López Obrador, y, en (17f), las del economista peruano Waldo Mendoza. La existencia de una retransmisión directa y la identidad de Loc 2 han podido saberse del mismo modo en todos los casos. Collins califica de "afortunados" 163 (felicitous) los usos de discurso directo no marcado en los cuales el contexto lingüístico permite recuperar la identidad de Loc 2. Desde luego, todos los casos que registro en mis materiales son de este tipo.

Obviamente, siempre existe la posibilidad de que el contexto lingüístico tampoco refiera el origen de una declaración ajena a Loc 1, en cuyo caso resultaría

${ }^{163}$ Collins 2001: 92. 
ineludible apelar al contexto extralingüístico para decodificar apropiadamente el enunciado. El que, por cuestiones de rigor metodológico, solamente se hayan recogido ejemplos "afortunados" acaso podría explicar parcialmente los pocos registros que, de esta modalidad de discurso directo, contiene el corpus.

Así pues, en esta forma de discurso directo, a diferencia de todas las anteriores, Loc 1 no indica de manera explícita que el enunciado no es de su autoría original: en términos de Collins, ${ }^{164}$ el locutor no señala, de manera formal, que existe una heteroglosia discursiva. La ausencia de indicaciones del cambio de nivel discursivo produce que, en principio, las supuestas palabras de Loc 2 parezcan de Loc 1. Se trata, pues, de lo que Rivarola y Reisz de Rivarola denominan conjunción discursiva, es decir, "la superposición de las acciones verbales de un hablante que refiere y de un hablante cuyo discurso es referido". ${ }^{165}$ Los resultados pragmáticos a que esto conlleva son diversos y deben interpretarse en función de casos concretos.

De manera general, pero sin pretensiones de universalidad, es posible decir que, al conjuntar ambos niveles discursivos, Loc 1 se apodera del sistema conceptual de Loc 2 y actúa como si se tratara del propio: hay fusión, y no distanciamiento, entre los puntos de vista de Loc 1 y Loc 2. En otras palabras, mediante la simple reproducción del enunciado de Loc 2, sin indicaciones de la entidad responsable por su enunciación, Loc 1 se apropia de las palabras ajenas y asume la responsabilidad del contenido: Loc 1 se identifica con Loc 2. En estos casos, nos hallamos ante lo que Bajtín llama motivación seudoobjetiva: "Conforme a todos los indicios formales, la motivación es autoral; el autor se solidariza con ella

${ }^{164}$ Collins 2001.

${ }^{165}$ Rivarola y Reisz de Rivarola 1984: 152. 
formalmente, pero de hecho la motivación yace en el horizonte subjetivo de los personajes". ${ }^{166}$

Siempre que no se trate de un ejemplo de discurso bivocal de orientación múltiple, ${ }^{167}$ Loc 1 se solidariza con las intenciones del enunciado de Loc 2. En todos los casos, la organización editorial admite finalmente la ideología subyacente $^{168}$ al hacerse responsable de la enunciación final. Hay, en consecuencia, una alineación ideológica del periódico con Loc 1, y de este con Loc 2. El titular (17f) es un magnífico ejemplo de ello.

Por esta razón, los casos de discurso directo no marcado y sin orientación múltiple son la variedad más directa del discurso ajeno en los titulares periodísticos. De ninguna manera lo es el discurso directo marcado ortográficamente, como afirman Fernández Lagunilla y Pendones: ${ }^{169}$ las marcas tipográficas constituyen, a todas luces, una interferencia explícita de Loc 1 en el enunciado de Loc $2 .^{170}$

Registro diecisiete casos de discurso directo no marcado en la muestra cuantificada. Esta cifra representa únicamente el 4\% (17/441) del total de encabezados donde se reproduce de manera directa un supuesto enunciado de Loc 2. Se trata de titulares publicados en los diarios Clarín, El Comercio, El Mercurio, El Tiempo, El Universal y Hoy. Para realizar un análisis cuantitativo pormenorizado de esta variedad del discurso directo, sería necesaria una muestra

\footnotetext{
${ }^{166}$ Bajtín (1935) 1986: 134-135. En nuestros términos, el autor corresponde a Loc 1, y el personaje, a Loc 2.

${ }^{167}$ Es decir, cuando Loc 1 actualiza las palabras de Loc 2 con un sentido distinto, a fin de manifestar una postura discordante, como en la ironía o la parodia (Bajtín [1963] 1986: 280291).

${ }^{168}$ Van Dijk 2003.

${ }^{169}$ Fernández Lagunilla y Pendones 1997: 86.

${ }^{170} C f$. Leech y Short 1981: 322.
} 
más representativa $\mathrm{y}$, por consiguiente, de mayores dimensiones y centrada exclusivamente en esta modalidad del discurso ajeno.

El propósito fundamental de las cuantificaciones en esta investigación es el de presentar un panorama general de los distintos procedimientos utilizados en la formulación de encabezados al aludir a actos discursivos ajenos. Sin embargo, con base en los testimonios de la muestra cuantificada y de los sucesivos corpus piloto, pueden plantearse, a título de orientación preliminar, las siguientes observaciones generales sobre esta variedad del discurso ajeno de mínima incidencia evidente en los encabezados: en primer lugar, que el discurso directo no marcado se presenta en periódicos de todo el mundo hispánico: ya en Europa, ya en América; en segundo lugar, que se observa con mayor frecuencia en la llamada prensa popular o sensacionalista, sobre todo en sus primera planas, y en tercer lugar, que se acude a él en todas las secciones, pero más cuando se trata de noticias de espectáculos, cultura, deportes, ciencias y tecnología. A partir de ello, puede sugerirse que, en principio, el discurso directo no marcado es relativamente habitual en la prensa sensacionalista y, acaso por ello, parece estar hasta cierto punto estigmatizado entre los redactores de los periódicos no populares, que suelen evitarlo en secciones cruciales desde el punto de vista socio-político (nacional, internacional, política, economía). Como veremos más adelante, esta variedad del discurso directo se presta con cierta facilidad a diversos efectos de sentido, no siempre asociados con los valores sociales impuestos por el discurso de la prensa más tradicional acerca del supuesto trabajo honesto de los medios. 


\subsection{Consideraciones finales}

El discurso directo se caracteriza, en principio, por la retención del sistema deíctico de Loc 2 y que se asocia convencionalmente con el polo semántico de una supuesta retransmisión literal. En función de su complejidad estructural, se identifican dos grandes variedades: marcado y no marcado. En la primera, se añade explícitamente alguna forma al supuesto enunciado de Loc 2, a fin de sugerir la existencia de una retransmisión literal. En la segunda, el supuesto enunciado de Loc 2 se retransmite sin indicaciones explícitas.

Los encabezados presentan dos tipos de marcas de discurso directo: verbo subordinante e índices gráficos. El verbo subordinante puede hallarse expreso o elidido, y el segmento que lo contiene, que hemos llamado $\mathrm{S} 1$, puede situarse en los titulares antes o después de las palabras ajenas, que hemos denominado S2. El eje deíctico de S1 es Loc 1, y el del S2, Loc 2. En el caso de las formas marcadas, el anclaje de S2 es denunciado, más que por formas lingüísticas contenidas en él, por la estructura ${ }^{171}$ sintáctico-ortográfica que lo rodea: ya sea que contengan indicaciones de primera o segunda persona, o que reproduzcan gestos, sonidos e interjecciones, o que presenten vocativos o formas verbales en imperativo, o no, las estructuras abstractas que he descrito en páginas anteriores se asocian con la significación general del discurso directo $-\mathrm{y}$ por tanto con un S2 anclado situacionalmente en Loc 2-, debido al principio de la irrenunciable correspondencia entre forma y significado: ya en el signo, ya en la estructura que lo contiene.

La retransmisión literal no es más que un supuesto, incluso en las variedades marcadas o doblemente marcadas del discurso directo. La alteración de las

\footnotetext{
${ }^{171}$ Entendida como la relación que mantienen entre sí los elementos lingüísticos, incluidos, para nuestro caso, los propios de la enunciación escrita.
} 
palabras ajenas es flagrante en los titulares: esto se evidencia no solo al comparar el encabezado con el cuerpo de la noticia, sino a menudo con la simple lectura del titular. Por ejemplo, cualquier hablante nativo de la lengua española se percata en (18) de la ausencia de artículos, fenómeno usual en los titulares y en otros géneros discursivos donde la tensión entre economía e informatividad es llevada al límite. Resulta obvio, pues, que el enunciado ha sufrido alteraciones a pesar de la presencia de comillas.

(18) 'Niño murió en brazos de señora' [LAN 24/01/10: 14A]

Al contrario de lo que suele decirse, el discurso directo no garantiza un respeto total a la forma del enunciado originario, sino únicamente un mantenimiento del anclaje deíctico en Loc 2. Ni siquiera puede asegurarse que el discurso directo reproduzca el contenido de las palabras ajenas, pues, como hemos dicho, el simple desplazamiento de contexto modifica el sentido del enunciado.

En principio, las marcas dobles enfatizan la supuesta literalidad de S2, como resultado de la contrariedad que se presenta entre la situación que acabamos de describir y las necesidades inherentes al discurso periodístico de insuflar veracidad al texto: la marca del verbo subordinante —en cualquiera de las estructuras aquí descritas - aporta una instrucción interpretativa básica de transcripción literal de S2, y la marca ortográfica subraya que debe interpretarse así alguno de sus constituyentes en particular. En la mayoría de los casos se trata de todo el S2, pero no siempre (sobre todo en periódicos mexicanos). Sea como fuere, la posibilidad de destacar como reproducción literal parte de lo así ya marcado implica que, en el discurso de los titulares periodísticos, la esencia selectiva del discurso directo puede llevarse sucesivamente a diversos niveles intratextuales, sin que en ningún caso ello garantice una verdadera 
correspondencia entre S2 o alguna parte de él y las palabras realmente emitidas por Loc 2.

Hay periódicos, como el chileno El Mercurio y el español El País, que no presentan casos de S1 - ya sea con verbo expreso o elidido- como marca única de discurso directo. En otras palabras, el discurso directo marcado siempre aparece en esos diarios con comillas. Esto explica, al menos de manera parcial, las altas frecuencias relativas de uso de las formas marcadas ortográficamente o doblemente marcadas que registran estos diarios con respecto a todos los demás. Es preciso asumir, por tanto, que en periódicos como estos - minoritarios, de acuerdo con mis materiales - las comillas son el elemento básico que indica la supuesta repetición literal, en total concordancia con la normatividad ortográfica vigente. Sin embargo, la completa ausencia de comillas en ciertos encabezados de otras publicaciones y su uso restringido a algún constituyente de S2 parece apuntar a que la estructura con oración subordinante constituye la fórmula básica del discurso directo marcado en los encabezados periodísticos.

La ausencia de un segmento subordinante y el uso de índices gráficos puede encontrar su motivación, además de en las convenciones ortográficas, en los condicionamientos de extrema economía lingüística propios de este tipo de discurso y también en razones de carácter ideológico. Volveré más adelante a este último punto.

Para algunos gramáticos, el orden S2-S1 resulta de un proceso similar a los de focalización: se adelanta un segmento al principio de la oración para poner de relieve su contenido informativo, con lo cual se otorga al contenido de S2 "una interpretación remática similar a la de los demás segmentos focalizados". ${ }^{172}$ Esto podría explicar, hasta cierto punto, la alternancia entre los órdenes de

${ }^{172}$ RAE y AALE 2009: $\$ 43.9 b$. 
constituyentes S1-S2 y S2-S1 en los titulares: Loc 1 desea destacar en unos casos las palabras de Loc 2 en relación con el resto del contenido del mensaje y en otros no. El análisis cuantitativo de mis materiales ofrece, sin embargo, precisiones adicionales que revelan claras preferencias por una u otra ordenación en los distintos periódicos, independientemente del contenido de la noticia.

Como hemos dicho, en términos absolutos es mucho más abundante el orden S2$\mathrm{S} 1$ que S1-S2 en los titulares que toman como marca de discurso directo la sola presencia de un segmento subordinante, ya sea con verbo expreso o elidido. Esto se observa particularmente en La Opinión, El Universal y El Tiempo. Parecen preferir el orden S1-S2 los periódicos Clarín, El Comercio, El Nacional, Hoy y La Nación, pero es verdad que no se registran muchos casos en ninguno de estos últimos diarios. En ambas disposiciones y en todos los diarios, son mucho más frecuentes los encabezados con elipsis de verbo de habla que con verbo expreso, comportamiento que no resulta nada extraño dadas las condiciones de extrema economía lingüística características de este tipo de discurso.

En los casos de doble marca, la disposición S1-S2 presenta siempre una mayor frecuencia de uso. Los pocos casos de orden $\mathrm{S} 2-\mathrm{S} 1$ casi se restringen a $\mathrm{La}$ Opinión, El Universal y El Tiempo (también se registra algún caso en El Mercurio), es decir, los mismos que claramente prefieren esta disposición cuando no hay comillas en S2. En los demás periódicos —Clarín, El Comercio, El Nacional, Hoy, La Nación y El País-, la doble marca aparece siempre en secuencias con el orden S1-S2. Puesto que en El Mercurio no registro sino apenas un caso aislado de doble marca y orden $\mathrm{S} 2-\mathrm{S} 1$ frente a muchos otros con el orden inverso, podría añadirse dicho periódico a este segundo grupo. Por cuanto los titulares con orden S1-S2 se multiplican cuando hay comillas e incluso hay un periódico (El País) que solamente acude a este orden cuando S2 se entrecomilla, podemos confirmar que existe una clara tendencia en la prensa 
hispánica a asignar un carácter formulaico al orden S1-S2 con las palabras de Loc 2 entrecomilladas. Esto no sucede con el orden S2-S1, que suele aparecer sin comillas.

Si bien el orden S2-S1 es más frecuente que S1-S2 en los periódicos de Estados Unidos, México y Colombia, en términos absolutos es más abundante la disposición S1-S2: esta última alcanza el 54\% (95/176) de todos los casos donde las supuestas palabras de Loc 2 están subordinadas a un S1, mientras que la disposición inversa es del 46\% (81/176). Las proporciones, sin embargo, se polarizan notoriamente si se elimina el sesgo que impone la inclusión en tales cifras de los testimonios procedentes del diario mexicano El Universal, que registra, en comparación con los demás periódicos, una indiscutible preferencia por el discurso directo frente a otras formas de discurso ajeno — por ejemplo, acapara por sí solo el 49,4\% (87/176) de todos los casos de discurso directo hipotáctico- y que, como acabamos de decir, ostenta una marcada predilección por el orden de constituyentes S2-S1. En efecto, la frecuencia de uso del orden S1-S2 se eleva hasta el $85,4 \%$ (76/89) en la suma de testimonios de discurso directo hipotáctico publicados en los nueve diarios restantes, mientras que la de S2-S1 se reduce al 14,6\% (13/89).

La tendencia general en la prensa del mundo hispánico apunta, pues, a la preferencia por el orden de constituyentes S1-S2. Esto no supone una divergencia con los datos de Dubský y Heredia, ${ }^{173}$ Heredia, ${ }^{174}$ Romero Álvarez ${ }^{175}$ y Moreno de Alba, ${ }^{176}$ quienes observan lo contrario en muestras de prensa cubana y mexicana. En realidad, estos datos revelan que existen regiones en el continente americano que se alejan en mayor o menor medida de la tendencia general, y que

\footnotetext{
${ }^{173}$ Dubský y Heredia 1977: 33.

${ }^{174}$ Heredia 1986.

${ }^{175}$ Romero Álvarez 1990: 150-151.

${ }^{176}$ Moreno de Alba 1996: 45.
} 
algunos ejemplos de esas zonas son Cuba, Estados Unidos, Colombia y, especialmente, México.

La alternancia entre las distintas marcas ortográficas obedece claramente a una motivación económica. Las comillas inglesas ("”) son la marca más abundante, seguidas por las simples (") y, por último, las angulares («»). Las últimas son las que ocupan un espacio mayor en las planas, y ningún periódico de la muestra cuantificada las utiliza de manera exclusiva: siempre alternan con otras (por ejemplo, en el venezolano El Nacional). Las comillas simples - las tipográficamente más pequeñas - se utilizan cada vez más: alternan con las inglesas en el periódico costarricense La Nación, y los diarios El Tiempo, de Colombia, La Opinión, de Estados Unidos, las emplean en sus titulares como único índice gráfico de discurso directo. Queda aclarado, por ende, que, al menos en lo concerniente a los encabezados, las alternancias tipográficas no son tan arbitrarias ni se deben solamente a la labor intertextualizadora, como sospechaba Girón Alconchel ${ }^{177}$ en sus notas introductorias al discurso ajeno en las noticias de prensa.

Además de las razones asociadas con la economía lingüística, que determina buena parte de las singularidades del discurso de los titulares, es evidente que las motivaciones ideológicas inciden directamente en la codificación de los encabezados (y no solo de ellos, por supuesto). De acuerdo con Bajtín, ${ }^{178}$ los diferentes modelos y variedades del discurso ajeno se subordinan siempre a los propósitos de Loc 1. Esto implica que, en cada uno de nuestros casos, la configuración lingüística del titular revela una estrategia discursiva diferente, llevada a la práctica por el locutor primario: en los titulares periodísticos, las palabras de Loc 2 son pasivas y sufren muy diversas alteraciones de forma y de contenido por parte de Loc 1. En este sentido, el discurso directo supone siempre,

\footnotetext{
177 Girón Alconchel 1993: 198.

${ }^{178}$ Bajtín (1935) 1986 y (1963) 1986; cf. Voloshinov (1929) 1992.
} 
ante todo, la selección, descontextualización y repetición de un determinado segmento del discurso de Loc 2, el cual, en las formas hipotácticas, es incorporado como complemento directo de un verbo que puede evaluar el contenido de esas palabras e incluso imponer una interpretación de todo el acto discursivo ajeno.

Van Dijk ${ }^{179}$ ha advertido, además, que el omitir información, o el expresarla con mayor o menor grado de detalle, se correlaciona de forma directa con la postura ideológica del locutor, ${ }^{180}$ es decir, Loc 1 para nuestros casos. Así, por ejemplo, la presencia o ausencia de S1 supone la mención u omisión de Loc 2 en el contexto donde se sitúa la cita supuestamente literal, y, en consecuencia, Loc 2 puede verse más o menos destacado, o diluido en el anonimato. En otras palabras, es posible hablar de locutores secundarios a los que Loc 1 asigna mayor o menor importancia, de acuerdo con el grado de detalle con que son aludidos: Loc 2 puede mencionarse de manera concreta y específica, de modo general e inespecífico, o simplemente no ser mencionado. Si se menciona de manera concreta y específica, será un locutor que Loc 1 considere importante, en función de su ideología subyacente; si no se menciona, Loc 1 lo considera irrelevante.

(19) a. Napolitano: "Washington no exige escáneres corporales" [ELP 22/01/10: 10]

b. Unicef: Es irresponsable la adopción de huérfanos [ELN 20/01/10: A8]

c. Llegarían a 600 los secuestros por año en el DF, alerta diputada [SOL 22/02/05: 1/A, 3. ${ }^{\mathrm{a}}$ ]

d. Zelaya radicará en México, revelan [UNI 23/01/10: A22]

He agrupado bajo (19) las cuatro formas de aludir a Loc 2 que presentan los titulares periodísticos en discurso directo marcado: en (19a), el locutor es

\footnotetext{
${ }^{179}$ Van Dijk 2003: 60-61.

${ }^{180}$ Al respecto, Longacre apunta en su estudio sobre los diálogos en el relato (1994: 132): "variations in $Q$ [uotation]F[ormulas] in regard to mention/non-mention of Speaker [...] are indexical of the intensity of participant interaction in reported dialogue" (cursivas en el original).
} 
mencionado de manera concreta y específica; en (19b) opera una sinécdoque generalizante, como veremos en seguida; en (19c), el locutor es aludido de manera inespecífica, y en (19d) no es mencionado. Podemos hablar de sujetos determinados en los $\mathrm{S} 1$ de los casos (19a) y (19b), ${ }^{181}$ y de sujetos indeterminados en $(19 c)$ y (19d).

Los sujetos determinados —aquellos que Loc 1 considera dignos de mención específica - presentan dos variantes, en función de la correferencia que Loc 1 plantea entre el sujeto de S1 y Loc 2: casos de semantismo propio, esto es, aquellos donde existe una correferencia transparente o simétrica, y casos de sinécdoque generalizante, es decir, aquellos donde Loc 2 se halla representado por medio de una entidad de la cual forma parte. En (19a) hay un semantismo propio, pues Loc 2 es Janet Napolitano, secretaria de Seguridad Nacional de Estados Unidos. En (19b), en cambio, asistimos a una sinécdoque generalizante, ya que Loc 2 no es propiamente el fondo de la Organización de las Naciones Unidas, sino su director en Argentina, Andrés Franco.

La importancia conferida por Loc 1 a Loc 2 es mayor en los casos de sinécdoque generalizante que en los de semantismo propio: si bien aludir a alguien por su nombre ya implica concederle un valor destacado, hacerlo por medio del todo al que pertenece apunta a un estatuto preponderante en la escala de valores de Loc 1. La distribución de frecuencias de uso confirma que son menos los declarantes dignos de sinécdoque generalizante.

\footnotetext{
${ }^{181}$ Aunque toda sinécodque generalizante produce, por definición, un efecto de inexactitud, debe tenerse en cuenta que, al menos en mis materiales, la entidad general siempre es específica. Por ejemplo, la forma Unicef, de (19b), a todas luces posee una referencia concreta. La inexactitud se presenta al establecer la correferencia con Loc 2, que en este caso es su director en Argentina y no todo el Fondo.
} 
Poseen sujetos indeterminados los titulares (19c) y (19d). La importancia que Loc 1 otorga a los Loc 2 es, evidentemente, menor que en los casos (19a) y (19b): ni siquiera se mencionan sus nombres. En función del valor asignado por el periodista, los sujetos indeterminados pueden ser explícitos o tácitos.

En (19c), la voz genérica diputada desempeña la función de sujeto gramatical. El locutor secundario - al que alude tal denominación - es Irma Islas León, la entonces presidenta de la Comisión de Seguridad Pública de la Asamblea Legislativa del Distrito Federal, México. En (19d), la forma flexiva de tercera persona del plural (-en), indicadora de una oración impersonal, ${ }^{182}$ permite reconocer un sujeto gramatical inespecífico; el agente del proceso es el político hondureño César Ham.

Un sujeto explícito indeterminado - como diputada, experto o funcionariosupone un Loc 2 más importante que el aludido por medio de un sujeto tácito en una oración impersonal: en el primer caso — (19c)—, el agente está representado por una frase nominal imprecisa; en el segundo —(19d)—, apenas lo sugiere la desinencia del verbo. En cualquiera de estas dos posibilidades, la importancia atribuida por Loc 1 es menor que en los casos de sujeto explícito determinado.

La ideología subyacente de que habla Van Dijk ${ }^{183}$ condiciona, pues, la manera de aludir a Loc 2. De acuerdo con el grado de importancia que los valores ideológicos asignan a Loc 2, las cuatro estrategias se distribuyen, como hemos visto, a lo largo de un continuum, en cuyos extremos se hallan la sinécdoque generalizante y el sujeto tácito. Dicha gradación puede representarse de la siguiente manera: sujeto explícito determinado con sinécdoque generalizante -

${ }^{182}$ RAE y AALE 2009: $\$ 41.9$, RAE 1973: $\$ 3.5 .6 a$, entre otros. A juicio de Romero Gualda (1991: 544) y Hurtado (2009: 192-194), las construcciones impersonales en tercera persona del plural son más frecuentes en la prensa hispanoamericana que en la española.

${ }^{183}$ Van Dijk 2003. 
sujeto explícito determinado con semantismo propio - sujeto explícito indeterminado - sujeto tácito.

(20) a. Fox no logrará callarme, dice López Obrador [JOR 23/02/05: 1]

b. No me van a silenciar, reta López Obrador [SOL 23/02/05: 1/A]

c. No me van a callar: AMLO [LAP 23/02/05: 2-3]

d. ¡NO ME CALLARÁ! [LAP 23/02/05: 1]

En la serie (20), retomo de mi corpus piloto cuatro titulares de periódicos mexicanos alusivos a una misma declaración: el entonces jefe de gobierno del Distrito Federal, Andrés Manuel López Obrazor — abreviado AMLO en (20c)—, responde a una supuesta amenaza del entonces presidente Vicente Fox. ${ }^{184}$ Los tres primeros ejemplos son formas marcadas por segmento subordinante; el último es no marcado. Destaca en estos ejemplos la variedad de formas empleadas para citar de forma supuestamente literal las mismas palabras: sujeto expreso, sujeto tácito y construcción impersonal en tercera persona del plural; futuro sintético y futuro perifrástico; usos de los verbos callar y silenciar. Pero, en las formas marcadas, también destacan las diferencias en la formulación de S1.

En (20a) y (20b), el verbo subordinante se halla expreso; en (20c), elidido. La elección de estas formas no es fortuita: naturalmente, responde a estrategias discursivas específicas, motivadas por patrones ideológicos compartidos por Loc 1 y la organización editorial. Como hemos dicho, la elección de un verbo subordinante concreto frecuentemente implica que Loc 1 imponga al destinatario su lectura del acto de habla de Loc 2: en los titulares periodísticos, es muy común que el locutor primario exponga su interpretación del acto ilocucionario de Loc 2. Es el caso de (20b): Loc 1 lo describe como una provocación. En contraste, la elección de formas verbales referencialemente más neutras en los enunciados

${ }^{184} \mathrm{En}(17 \mathrm{e})$ se ha reproducido parte de la noticia publicada en uno de los periódicos. 
primarios, como en los ejemplos (20a) y (20c), orienta el sentido del enunciado en otra dirección: en este par de ejemplos, las indicaciones de futuridad y de primera persona, reproducidas por Loc 1 en el enunciado secundario, encaminan la interpretación del acto ilocucionario hacia uno comisivo. ${ }^{185}$

Esto parece refutar las aseveraciones de Coulmas, ${ }^{186}$ quien sostiene que el discurso directo nunca describe la fuerza ilocucionaria del acto de habla referido, sino que la "expresa". Ciertamente, el discurso directo marcado permite omitir la descripción explícita del acto ilocucionario, pero esto solo ocurre en los casos de elipsis o de verbos inespecíficos. Ahora bien, la elisión del verbo tampoco responde siempre a la existencia subyacente de un verbo de habla semánticamente inespecífico: sin negar las incuestionables necesidades de economía del discurso de los titulares, existe la posibilidad de que Loc 1 busque deliberadamente ocultar su interpretación del acto de habla ajeno, en perjuicio, claro está, de la informatividad del texto. Recuérdese que el discurso periodístico se ha caracterizado, tradicionalmente, por evitar la ostensión del sujeto hablante.

El discurso directo marcado establece cierta distancia entre Loc 1 y las supuestas palabras de Loc 2. Esta resulta del grado de compromiso o responsabilidad condicionada que Loc 1 asume con base en el valor de verdad que atribuye al enunciado reproducido. ${ }^{187}$ No hay que olvidar que para algunos autores ${ }^{188}$ existe una modalidad lingüística específica, la citativa, que señala la falta de compromiso del locutor con respecto al valor veritativo del enunciado secundario. La distancia y, secundariamente, el compromiso que Loc 1 establece con respecto al enunciado secundario se manifiestan por medio de marcas

\footnotetext{
185 Searle 1976.

${ }^{186}$ Coulmas 1994: 3553.

${ }^{187}$ Cf. Quaglia 2001: 61.

${ }^{188}$ Palmer 1986, por ejemplo.
} 
formales destinadas a indicar que la información contenida en el enunciado proviene de un Loc 2, a las cuales Chafe ${ }^{189}$ denominó evidenciales.

(21) Hubo y todavía hay vida en Marte, afirma la Agencia Europea Espacial [JOR 26/02/05: 3a]

Sabemos, por conocimiento del contexto extralinguiístico, que el contenido de S2 en (21) es muy comprometedor, pues entraña implicaciones considerables. Gracias a su valor evidencial, el verbo subordinante permite a Loc 1 referir el origen del enunciado secundario, distanciarse de su contenido y atribuir a Loc 2 la responsabilidad del acto de habla. La descripción del acto como una aserción ajena — presente en el modus — contribuye, pues, a asignar un carácter dubitativo a la fiabilidad de la información contenida en el dictum.

En cuanto al discurso directo no marcado, es preciso decir que, a pesar de su reducida frecuencia relativa de uso, resulta insoslayable para caracterizar el discurso ajeno en los titulares periodísticos: en primer lugar, es más fácil encontrarlo en el sitio más prominente de todo el periódico —es decir, en la primera plana- que en cualquier otro lugar de este; en segundo lugar, da lugar a configuraciones polifónicas bastante complejas cuyos resultados pragmáticos deben interpretarse en función de casos concretos.

De manera general, sin embargo, hemos dicho que, a falta de estructuras sintáctico-ortográficas fijas con valor evidencial, el discurso directo no marcado tiende a lo que Bajtín denomina motivación seudoobjetiva, ${ }^{190}$ esto es, donde Loc 1 se solidarizariza con el punto de vista de Loc 2. Aquí Loc 1 solo repite, aparentemente, las supuestas palabras de Loc 2, cuya forma está determinada, de acuerdo con el sentido mismo del enunciado, por las elecciones concretas que

\footnotetext{
${ }^{189}$ Chafe 1986.

${ }^{190}$ Bajtín (1935) 1986: 134-135.
} 
hace el locutor secundario (y no el primario). Así, por ejemplo, en (22) Loc 1 suscribe el punto de vista que asume Loc 2, es decir, el economista peruano Waldo Mendoza, con respecto a la necesidad de no cambiar el modelo económico que ha adoptado Perú durante los últimos años. ${ }^{191}$ Puede verse que, al fusionar ambos niveles discursivos, Loc 1 se apodera de las palabras ajenas y asume la responsabilidad del contenido:

(22) Mejor sigamos con el modelo [COM 24/01/10: A22]

Esto, sin embargo, no es válido para todos los casos: en ocasiones, sobre todo en la llamada prensa sensacionalista, Loc 1 se apropia de las palabras ajenas y las actualiza con un sentido distinto, a fin de manifestar un punto de vista discordante, como sucede en la ironía o la parodia. Bajtín llamó a esto discurso bivocal de orientación múltiple. ${ }^{192}$ Carente la enunciación escrita de rasgos formales denunciantes — como la entonación—, su identificación exige atender a otras cuestiones.

(23) DIOSITO, ¡ILUMÍNALOS! [LAP 27/09/04: 1]

Es el ejemplo (23) un caso muy particular. Procedente del corpus piloto, alude a una declaración del arzobispo primado de México, Norberto Rivera Carrera, relativa a una reunión que tendrían el entonces presidente de México, Vicente Fox, y el alcalde de la ciudad de México, Andrés Manuel López Obrador. El cotejo de las diversas notas informativas alusivas al asunto permite concluir que las palabras que Rivera pronunció fueron más o menos las siguientes:

El diálogo siempre es un buen instrumento para terminar con viejos enconos, para terminar con malos entendidos; el diálogo siempre será un instrumento para llegar a acuerdos, porque en este caso los que

\footnotetext{
${ }^{191}$ Para mayor información contextual, volver al caso (17f).

${ }^{192}$ Bajtín (1963) 1986: 280-291.
} 
vivimos en la ciudad de México requerimos que estos diálogos sirvan para llegar a acuerdos concretos, porque iqué bueno que se lleven muy bien!, ¡qué bueno que haya diálogo! Pero aquí necesitamos obras que se tienen que hacer a nivel de los gobiernos federal y local.

En el titular el texto original ha sido completamente alterado. Loc 1 hace oír un discurso que atribuye irónicamente al cardenal, en el cual se pide a una fuerza divina que proporcione claridad o lucidez a varios sujetos para que estos alcancen un estado espiritual superior que les permita entender o descifrar el sentido profundo y esencia de algo. Loc 1 presenta la enunciación original, pues, como una plegaria o como parte de un diálogo con la entidad "Diosito", a la cual pide que suministre lucidez a otras entidades, que, de acuerdo con la nota informativa, son el presidente y el alcalde. Esta información contrasta con el contenido expresado en el cuerpo de la noticia. Inmediatamente se deduce, por tanto, que el encabezado no tiene ni pretende tener una intención informativa, como sería lo esperable en el discurso de los titulares.

Loc 1 presenta su interpretación del discurso de Loc 2 con términos que utilizaría Loc 2 y desde el eje deíctico de Loc 2, pero sin atribuirle el enunciado. En otras palabras, Loc 1 produce una interpretación y una reformulación del enunciado de Loc 2 desde el sistema conceptual de este. En esta articulación especular, es evidente que el tono irónico de (23) marca explícitamente una distancia entre Loc 1 y Loc 2: a pesar de que Loc 1 da la palabra a Loc 2 y expresa su supuesto punto de vista sin marcas de espacio intertextual, no se identifica con él. Antes bien, debido a los términos con que se formula la interpretación del acto discursivo ajeno, Loc 2 se presenta hasta cierto punto ridiculizado. 


\section{DISCURSO INDIRECTO}

Los investigadores han dedicado mucha más atención al discurso indirecto que a las demás variedades del discurso ajeno. Esto se debe a que constituye el resultado de una estrategia comunicativa extremadamente compleja que comporta peculiaridades morfosintácticas muy diversas. ${ }^{1}$ En este capítulo abordaré, desde luego, solo aquellos asuntos pertinentes para la caracterización de los encabezados periodísticos en español.

Conocido también como estilo indirecto u oratio obliqua, el discurso indirecto suele definirse como la variedad del discurso referido donde el locutor primario altera abiertamente el enunciado del locutor secundario para expresar, con sus propias palabras, el contenido del texto ajeno: "El que habla o escribe refiere por sí mismo lo que otro ha dicho", 2 afirma Gili Gaya, por ejemplo. Posiciones similares se observan en los trabajos de Voloshinov, ${ }^{3}$ Jespersen, ${ }^{4}$ Coulmas, ${ }^{5} \mathrm{Li}^{6} \mathrm{y}$ Maingueneau, ${ }^{7}$ entre otros.

El acto de referir un enunciado ajeno con palabras propias implica una adaptación de la deixis exofórica ${ }^{8}$ a la nueva situación enunciativa, esto es, cambiar el anclaje del enunciado originario a las coordenadas personales,

\footnotetext{
${ }^{1} \mathrm{Li}$ 1986: 40, por ejemplo.

${ }^{2}$ Gili Gaya 1967 \$219. II.

${ }^{3}$ Voloshinov (1929) 1992: 173.

${ }^{4}$ Jespersen (1924) 1975: 349.

${ }^{5}$ Coulmas 1994: 3552.

${ }^{6} \mathrm{Li}$ 1986: 34.

${ }^{7}$ Maingueneau 1981: 103. Cf. también RAE (1931) 1962: §382 y 1973: §3.19.4a, Leech y Short 1981: 318, Gómez Torrego 2002: §3.3.4.2, entre muchos otros.

${ }^{8}$ Brecht 1974.
} 
espaciales y temporales de la enunciación donde se actualiza el discurso ajeno.9 En el discurso indirecto, Loc 1 no asume, pues, el eje deíctico de Loc 2, sino que ajusta el enunciado primitivo a su propia situación comunicativa, con lo cual suele obtenerse un contexto transparente, ${ }^{10}$ de acuerdo con el principio de sustitución de idénticos (o sustitución salva veritate), de Leibnitz: dos o más denominaciones correferenciales —en este caso, los deícticos correspondientes a la situación comunicativa de Loc 1 y de Loc 2 - pueden intercambiarse sin alterar el valor de verdad del enunciado. Por ello, en repetidas ocasiones se ha dicho que las formas indirectas no son histriónicas. ${ }^{11}$

En opinión de la ScaPoLine, ${ }^{12}$ el hecho de que las palabras de Loc 2 se subordinen a la situación enunciativa de Loc 1 constituye un importante rasgo definitorio del discurso indirecto. ${ }^{13}$ En atención a la transposición de deícticos que dicha "incorporación enunciativa"14 implica, algunos autores, como Genette y Todorov, ${ }^{15}$ han llamado discurso transpuesto a esta variedad del discurso ajeno.

(1) a. Pelé dice que él fue el mejor [LAN 18/01/10: 63A]

b. Schumaher reconoce que es supersticioso [ELN 21/01/10: B6]

\footnotetext{
${ }^{9}$ Jespersen (1924) 1975: 349, RAE (1931) 1962: §382, Gili Gaya 1967 §219. II, Verdín Díaz 1970: 57-64, Todorov (1972) 2000: 347, Alcina y Blecua (1975) 2001: §8.4.1, Maingueneau 1981: 103, Comrie 1986, Li 1986: 34, Girón Alconchel 1989: 74, Bruña Cuevas y Muñoz Romero 1992: 226-243, Hickmann 1993: 65, Reyes 1993: 12, Coulmas 1994: 3552, Vicente Mateu 1994: 117-118, Maldonado 1999: 3583-3584, Van der Houwen 2000: 28, Vandelanotte 2004: 489-520, RAE y AALE 2009: §43.10e.

${ }^{10}$ Maldonado 1991: 126.

${ }^{11}$ Genette (1972) 1989: 229 y (1993) 1998: 36, Wierzbicka 1974: 284, Reyes 1994a: 612, entre otros. $C f$. RAE y A ALE 2005: 763.

${ }^{12}$ Nølke, Fløttum y Norén 2004: 62.

13 Cf. Banfield 1973: 3, Comrie 1986: 266, Coulmas 1986: 2, Bruña Cuevas 1993: 39; Reyes1993: 15 y 1994a: 592.

${ }^{14}$ Nølke, Fløttum y Norén 2004: 62.

${ }^{15}$ Genette (1972) 1989: 229, Todorov (1965) 1975: 60.
} 
En los titulares (1a) y (1b), por ejemplo, los ejes deícticos se hallan anclados en sus respectivos Loc 1, a pesar de que los Loc 2 -Pelé en (1a) y Schumaher en (1b) - constituyen el origen del contenido expresado. En ambos casos, la transposición deíctica es revelada por los morfemas flexivos de persona en las oraciones subordinadas: el contexto es transparente por cuanto el anclaje deíctico que permite conocer el referente de dichos morfemas corresponde a la situación de Loc 1 y no de Loc 2. Evidentemente, si se conservara el punto de referencia de la enunciación originaria, los morfemas flexivos serían de primera persona. Lo mismo puede decirse del pronombre personal de tercera persona que se observa en (1a).

Por supuesto, la deixis personal no necesariamente experimenta transposiciones cuando el enunciado originario alude a entidades que no participan directamente en el acto de enunciación que actualiza las palabras de Loc 2: al igual que en el discurso directo, si una entidad no está presente en el acto de enunciación primaria o secundaria, estará representada, en ambos enunciados, por formas de tercera persona. En estos casos, los deícticos espaciales y temporales pueden transponerse, pero no siempre son aptos para permitir el reconocimiento de la identidad de Loc 2 como participante en el cuadro figurativo de la enunciación originaria, ${ }^{16}$ además de que no necesariamente sufren alteraciones cuando Loc 1 y Loc 2 comparten el mismo espacio y el mismo tiempo. Es por esta razón que, también para caracterizar el discurso indirecto, es necesario acudir al principio de la correspondencia irrenunciable entre forma y significado en configuraciones gramaticales abstractas. ${ }^{17}$

\footnotetext{
${ }^{16} C f$. RAE y AALE $2009: \$ 43.9 \mathrm{c}$

${ }^{17}$ Fillmore 1982, Goldberg 1995, Kay 1997, entre otros.
} 
De acuerdo con Maingueneau, ${ }^{18}$ siempre acarrean pérdida de autonomía enunciativa las incorporaciones del discurso indirecto, pues adecuan un enunciado a una situación enunciativa diferente de aquella en que se produjo. En consecuencia, el enunciado ajeno se integra totalmente al propio, ${ }_{19}^{19}$ lo que permite a Loc 1 no solo alterar los deícticos, sino reformular por completo las palabras de Loc 2.

El discurso indirecto presenta, pues, diferentes grados de fidelidad con respecto al enunciado originalmente producido por Loc 2, que van de copias casi exactas, con cambios mínimos en los elementos deícticos, a reformulaciones sin ninguna similitud formal con el texto original. Voloshinov — quien propuso nombrar "tendencia analítica" a la propiedad de referir con palabras propias lo dicho por otro- llamó modalidad analítico-discursiva del discurso indirecto a la variedad en la que se respetan "las palabras y los giros del discurso ajeno que caracterizan la fisonomía subjetiva y estilística del enunciado del otro en cuanto expresión", ${ }^{20}$ y modalidad analítico-temática a aquella que "se caracteriza por la tendencia a tematizar la palabra ajena, preservando en ella no tanto una elasticidad estructural, como la flexibilidad semántica" ${ }^{21}$ Desde los tratados clásicos sobre la materia, suele hablarse de interpretaciones de dicto cuando un enunciado en discurso indirecto se decodifica como modalidad analítico-discursiva, y de interpretaciones de re cuando la lectura que se le asigna es de modalidad analítico-temática. Debe recordarse que, en ambos casos, hay una adaptación del discurso original al discurso presente, que solo tiene un origen deíctico, Loc 1, y un punto de vista predominante, Loc $1 .^{22}$

\footnotetext{
${ }^{18}$ Maingueneau 1981: 103.

${ }^{19}$ Genette (1993) 1998: 44-45, Coulmas 1994: 3552, Nølke, Fløttum y Norén 2004: 74, entre otros.

${ }^{20}$ Voloshinov (1929) 1992: 174.

${ }^{21}$ Ibid.: 173.

${ }^{22}$ Coulmas 1986: 2, Reyes 1994a: 612.
} 
Las capacidades analítico-temáticas del discurso indirecto han sido advertidas por numerosos especialistas, cuyas descripciones pueden clasificarse en dos grandes grupos, de acuerdo con la naturaleza expansiva o reductiva de la reformulación estudiada. En efecto, en algunos casos el discurso indirecto comporta una paráfrasis del enunciado secundario, es decir, un desarrollo explicativo resultante de la interpretación de Loc $1 ;^{23}$ en otros, conlleva un resumen —o "macroestructura semántica", en términos de Van Dijk-, ${ }^{24}$ esto es, una síntesis del contenido y no una explicación, ${ }^{25}$ lo cual, en el caso discurso periodístico, es motivado por las evidentes necesidades de economía.

En todo caso, el discurso indirecto supone una apropiación de las palabras de Loc 2, las cuales, por su condición eminentemente pasiva, ${ }^{26}$ se ven alteradas en la medida que Loc 1 desee: mediante cambios mínimos en la deixis o por medio de una reformulación completa, ya sea una paráfrasis o un resumen. Si bien con ello el enunciado original puede enriquecerse y contextualizarse, también puede desvirtuarse por completo: ${ }^{27}$ naturalmente, esta interpretación está orientada desde la perspectiva de Loc 1, según su particular conocimiento del mundo y en función de sus intenciones o intereses comunicativos. Tal situación dota al discurso indirecto de cierta indeterminación, puesto que "el receptor no siempre es capaz de reconstruir a través de él las palabras pronunciadas en el discurso directo correspondiente" ${ }^{\text {"28 }}$ (el contexto lingüístico de los titulares periodísticos no permite, por cierto, distinguir con certeza las modalidades analítico-temática y analítico-discursiva, pues, como ya hemos dicho, la supuesta literalidad del

\footnotetext{
${ }^{23}$ McHale 1978, Coulmas 1985: 46, Reyes 1994a: 612, Fernández Lagunilla y Pendones 1997: 88, Méndez García de Paredes 2000b: 150. McHale (1978) considera apropiado asignar el apelativo "paráfrasis indirecta del contenido" al discurso indirecto.

${ }^{24}$ Van Dijk (1978) 1998: 43-57.

${ }^{25}$ Page 1973: 33, Sternberg 1982: 124, Waugh 1995: 163; cf. Maingueneau 1981: 100, Girón Alconchel 1993: 205.

${ }^{26}$ Bajtín (1963) 1986: 288.

${ }^{27}$ Entre otros, Romero Álvarez 2000: 99-100.

${ }^{28}$ RAE y AALE 2010a: $\$ 43.4 .2$.
} 
discurso directo no es más que una ley del discurso). Con vistas en ello, Maldonado $^{29}$ ha sostenido que solo es "real" la modalidad analítico-discursiva del discurso indirecto, es decir, la que comporta una interpretación de dicto.

Con fundamento en la noción de marca como elemento adicionador de complejidad estructural, ${ }^{30}$ distingo dos grandes variedades de discurso indirecto: marcado y no marcado. Las formas no marcadas - mayoritarias en mis materiales - han sido casi sistemáticamente desatendidas por la tradición gramatical.

(2) a. Advierte el Unicef que uno de cada 12 niños son explotados en el mundo [SOL 22/02/05: 15/A]

b. En el mundo explotan a uno de cada 12 niños [UNI 22/02/05: A7]

Los titulares bajo (2) aluden a un mismo acto de habla: el Fondo Internacional de las Naciones Unidas de Socorro a la Infancia dio a conocer información estadística acerca de la explotación infantil en el mundo. El testimonio (2a) constituye una forma marcada, pues presenta una oración subordinante con un verbo de habla conjugado y una oración subordinada introducida por una conjunción, estructura que, como veremos más adelante, se asocia convencionalmente con el significado básico de una reproducción analítica en una situación enunciativa diferente. El ejemplo (2b), en cambio, no puede interpretarse como discurso ajeno sin información contextual: es una forma no marcada.

A causa de su tendencia analítica, el discurso indirecto jamás se asocia con pretensiones de literalidad: como observa Genette, esta variedad de discurso ajeno "no da nunca al lector ninguna garantía y sobre todo ningún sentimiento de

\footnotetext{
${ }^{29}$ Maldonado 1991: 20.

${ }^{30}$ Givón 1995: 28; cf. §1, supra.
} 
fidelidad literal a las palabras 'realmente' pronunciadas". ${ }^{31}$ Además, aunque puedan imaginarse los términos en que supuestamente se expresó Loc 2, la cantidad de formas diferentes que puede adoptar el discurso indirecto es tan grande que resulta imposible reconstruir con certeza la forma original del enunciado ajeno. ${ }^{32}$ Es por ello que se ha hablado de responsabilidades de Loc 1 solo en cuanto a una supuesta la fidelidad del contenido y no de la forma: ${ }^{33}$ gracias a su tendencia analítica, el discurso indirecto "atiende más a lo que se dijo que a cómo se dijo". ${ }^{34}$

Por cuanto no supone literalidad, el discurso indirecto carece de las facultades histriónicas propias del discurso directo. ${ }^{35}$ Ello explica la normal ausencia de interjecciones, vacilaciones, imprecaciones, exclamaciones, vocativos, sonidos y gestos, así como de interrogaciones y órdenes directas, entre otras formas que comportan expresividad, ${ }^{36}$ verbales o no, que usualmente son reproducidas en discurso directo ${ }^{37}$ (en la lengua escrita, se pierden también las entonaciones características de los enunciados exclamativos, interrogativos e imperativos). ${ }^{38}$ Las pocas excepciones, matizan las Academias, se registran "siempre en la lengua oral relajada". ${ }^{39}$

\footnotetext{
${ }^{31}$ Genette (1972) 1989: 229; cf. Fernández Lagunilla y Pendones 1997: 87, Maldonado 1999: 3578.

32 Banfield 1973 : 4-6, Bal (1978) 1990: 144, Maingueneau 1981: 100, Coulmas 1985: 43, Reyes 1993: 31, entre otros.

${ }_{33}^{3}$ Por ejemplo, Voloshinov (1929) 1992: 173, Todorov [1968] 1975: 60, Verdín Díaz 1970: 69, Maingueneau 1981: 100, Coulmas 1985: 42, Li 1986: 38, Reyes 1993: 32, Fairclough 1995b: 81, Méndez García de Paredes 2000b: 150, RAE y AALE 2009: §43.10c y 2010a: §43.4.2; $c f$. Maldonado 1999: 3578.

${ }^{34}$ Reyes 1993: 45.

${ }^{35}$ Wierzbicka 1974: 300, Li 1986: 38, Reyes 1993: 45, entre otros.

${ }^{36}$ Entre otros, Todorov (1968) 1975: 60, Verdín Díaz 1970: 67, Banfield 1973: 7-8, Kvavik 1986: 337, Van der Houwen 2000: 28.

${ }^{37}$ Voloshinov (1929) 1992: 170, Banfield 1973: 7, Maingueneau 1981: 102, Coulmas 1985: 44, Maldonado 1991: 137, Sakita 2002: 190.

${ }^{38} C f$. Kvavik 1986: 337, por ejemplo.

${ }^{39}$ RAE y AALE 2009: §43.9q.
} 
A juicio de Vicente Mateu, este rechazo a los rasgos expresivos ocasiona la menor frecuencia de uso que, con respecto al discurso directo, presenta — según dice- el discurso indirecto en las conversaciones. ${ }^{40}$ Se ha dicho también que, por ello mismo, el discurso indirecto se emplea menos que el directo para referir contenidos afectivos y más para contenidos factuales. ${ }^{41}$ De hecho, Rivarola y Reisz de Rivarola consideran que resulta "menos vívido y efectivo para crear la ilusión de realidad", ${ }^{42}$ por lo que, al menos en la narrativa, suele emplearse para introducir información contextual. ${ }^{43}$ Además, opina Reyes, ${ }^{44}$ el hecho de ofrecer una interpretación ya realizada, que resume o parafrasea las palabras ajenas, lo torna apto para discursos formales, como ensayos o, en general, textos escritos. Como señala Voloshinov, ${ }^{45}$ el discurso indirecto se acompaña de cierta despersonalización del discurso referido, lo cual le ha valido calificativos como "veraz" o "epistemológicamente poco escandaloso". 46

El discurso indirecto constituye, con mucho, la variedad de discurso ajeno más abundante en mi corpus: representa el 61,2\% (2256/3689). El siguiente cuadro contiene la relación exhaustiva de frecuencias relativas de uso en cada diario: ${ }^{47}$

\begin{tabular}{|l|c|}
\hline \multicolumn{1}{|c|}{ Diario } & $\begin{array}{c}\text { Frecuencia relativa } \\
\text { de uso }\end{array}$ \\
\hline El País (Madrid) & $51 \%(129 / 253)$ \\
\hline
\end{tabular}

${ }^{40}$ Vicente Mateu 2007: 234.

${ }^{41}$ Reyes 1993: 45.

${ }^{42}$ Rivarola y Reisz de Rivarola 1984: 165.

${ }^{43}$ Sakita 2002: 190.

${ }^{44}$ Reyes 1993: 45.

${ }^{45}$ Voloshinov (1929) 1992: 173; $c f$. Verdín Díaz 1970: 144.

${ }^{46}$ Rivarola y Reisz de Rivarola 1984: 164.

47 Por diarios, la distribución global del discurso indirecto es la siguiente: El País, 5,7\% (129/2256); La Opinión, 4,9\% (111/2256); El Universal, 15,3\% (345/2256); La Nación, 9,6\% (217/2256); Hoy, 14,5\% (327/2256); El Tiempo, 8,4\% (189/2256); El Nacional, $10 \%$ (226/2256); El Comercio, 12,7\% (286/2256); El Mercurio, 11\% (247/2256); Clarín, 7,9\% (179/2256). 


\begin{tabular}{|l|l|}
\hline La Opinión (Los Ángeles) & $74,5 \%(111 / 149)$ \\
\hline El Universal (México) & $54,8 \%(345 / 630)$ \\
\hline La Nación (San José de Costa Rica) & $72,1 \%(217 / 301)$ \\
\hline Hoy (Santo Domingo) & $61,6 \%(327 / 531)$ \\
\hline El Tiempo (Bogotá) & $66,1 \%(189 / 286)$ \\
\hline El Nacional (Caracas) & $60,8 \%(226 / 372)$ \\
\hline El Comercio (Lima) & $71,5 \%(286 / 400)$ \\
\hline El Mercurio (Santiago de Chile) & $56,7 \%(247 / 436)$ \\
\hline Clarín (Buenos Aires) & $54,1 \%(179 / 331)$ \\
\hline
\end{tabular}

Con esto se confirma la tendencia de la prensa del mundo hispánico a formular en discurso indirecto los titulares con discurso ajeno. ${ }^{48}$ Puede verse que todos los diarios eligen formas de discurso indirecto en más de la mitad de los casos. Esta tendencia, no obstante, está particularmente acentuada en los diarios La Opinión, La Nación y El Comercio, que presentan frecuencias de uso de titulares en discurso indirecto que sobrepasan en más de diez puntos porcentuales, aproximadamente, la media aritmética del 61,2\%. El Tiempo sobrepasa ligeramente la media, mientras que Hoy y El Nacional presentan incidencias muy similares al promedio general. Por último, El País, El Universal, El Mercurio y Clarín acuden al discurso indirecto con menor profusión, pero siempre con más del 50\%. El angelino La Opinión es el que publica titulares en discurso indirecto en mayor proporción, mientras que el madrileño El País es el que lo hace con la menor frecuencia relativa.

\footnotetext{
${ }^{48}$ Fairclough (1988: 127) y Bell (1991: 209) llegaron a conclusiones similares para los artículos publicados en diarios anglosajones. Sorprendentemente, Short (1988: 65) asegura, por el contrario, que no hay un solo caso de discurso indirecto en su corpus de titulares de prensa británica.
} 


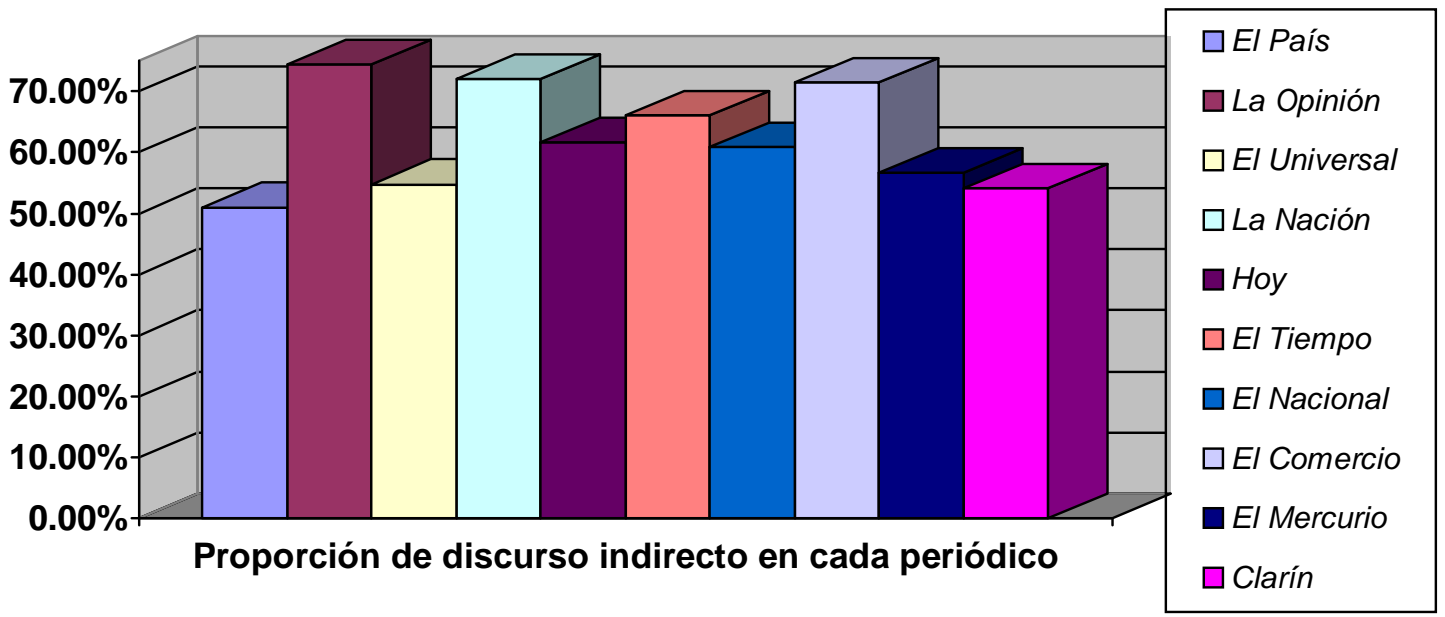

El 90,5\% (2041/2256) de los titulares en discurso indirecto de los diez diarios está representado por el discurso indirecto no marcado, mientras que solo el 9,5\% $(215 / 2256)$ corresponde a formas marcadas. Estas cifras evidencian la imperiosa necesidad de estudiar detenidamente las formas no marcadas.

\subsection{Discurso indirecto marcado}

Entiendo por marca de discurso indirecto cualquier forma que se añada explícitamente a la expresión transpuesta ${ }^{49}$ del enunciado primitivo a fin de sugerir la existencia de una reproducción analítica. En mis materiales registro, como marca prototípica, la concurrencia de un verbo de habla y de una conjunción subordinante, y, como marcas no prototípicas, la sola presencia explícita del verbo o de la conjunción, además de la preposición para seguida por un sintagma nominal en un adjunto periférico y del morfema desinencial -ría usado con valor de potencial citativo. En otras palabras, la construcción prototípica del discurso indirecto consta tanto de un verbo subordinante como de

\footnotetext{
${ }^{49}$ En el sentido aquí adoptado, que apela a la transposición o transformación deíctica.
} 
una conjunción indicadora de la hipotaxis, mientras que las construcciones no prototípicas se caracterizan por la elisión de cualquiera de los elementos constitutivos de dicho binomio, o bien por el uso de la preposición para o del morfema -ría con las especificaciones que mencionaremos más adelante.

Salvo en los casos de potencial citativo, cuyas peculiaridades aclararé después, los índices de retransmisión indirecta se hallan en el segmento correspondiente al nivel discursivo primario, es decir, el que es atribuible solamente a Loc 1, llamado aquí segmento 1 (S1). Allí es donde Loc 1 especifica, según el caso, elementos de la situación enunciativa originaria como emisor, receptor y circunstancias, y donde puede incorporar su interpretación de la fuerza ilocucionaria del acto de habla ajeno. El segmento 2 (S2), correspondiente al nivel discursivo secundario, contiene propiamente la reformulación analítica de las palabras de Loc 2 .

(3) a. El embajador en China dice que no es tan grave la suspensión del $\begin{array}{llll}\text { viaje } & S 1 & \text { S2 } & \text { [CLA 22/01/10: 7] }\end{array}$

b. Bruselas exige a Grecia que
S1 $\frac{\text { aclare su plan contra el déficit }}{\text { S2 }}$ [ELP 19/01/10: 20]

S1: Segmento 1 (nivel discursivo primario)

S2: Segmento 2 (nivel discursivo secundario)

En los casos que suponen una oración subordinada, como los de la serie (3), la representación de las palabras de Loc 2 - S2 o dictum - se halla siempre subordinada a una expresión introductora generada por Loc $1-\mathrm{S} 1$ o modus-, sin importar que el verbo subordinante se encuentre elidido. En ocasiones, la transposición a discurso indirecto obliga a ciertos cambios en las formas verbales del enunciado originario: como se sabe, todos los verbos subordinados son 
"relativos o indirectamente medidos", ${ }^{50}$ pues su representación modal y temporal está fijada por el contexto. Mucho se ha escrito acerca de las transformaciones que sufren las formas verbales del enunciado secundario en el discurso indirecto, en especial con relación a casuística de la concordantia o consecutio temporum, es decir, la relación de tiempos verbales que pueden aparecer en S2, dado un tiempo verbal determinado en S1. Debo advertir que no abundaré en este asunto por encontrarse ya suficientemente descrito y por no alejarse los encabezados de las normas generales; para su tratamiento específico, me remito a la bibliografía especializada. $^{51}$

\subsubsection{Verbo y conjunción subordinantes}

En sus descripciones del discurso indirecto, los gramáticos suelen identificar una estructura caracterizada, en primer lugar, por una oración subordinante con un verbo de habla y, en segundo, por una oración subordinada introducida por una conjunción completiva. ${ }^{52}$ De acuerdo con mis materiales, dicha configuración constituye la forma más abundante de discurso indirecto marcado: representa el $48,4 \%(104 / 215)$ de todos los casos donde se indica expresamente la existencia de una reproducción analítica.

\footnotetext{
${ }^{50}$ RAE 1973: §3.13.9.

${ }^{51}$ Jespersen (1924) 1975: 351, RAE (1931) 1962: §381 y 1973: §3.19.5-3.19.8, RAE y AALAE 2009: $\S \S 43.10 \mathrm{~m}-43.10 \mathrm{z}$ y $2010 \mathrm{a}$ : $\S \S 24.3 .1 \mathrm{c}$ y 24.3 .2 , R. Seco $1954: 228-229$, Gili Gaya 1967 : §220, Verdín Díaz 1970: 54-57, Rojo 1974 y 1976, Comrie 1986, Reyes 1993: 34-41, Delbecque y Lamiroy 1999: 2024-2026, Maldonado 1991: 132-136 y 1999, entre otros. Hay incluso trabajos que identifican supuestas discordancias entre la gramática normativa y el uso de los tiempos verbales en relaciones de dependencia dentro del discurso periodístico de determinados países (por ejemplo, Báez de Aguilar 2002: 77).

${ }^{52}$ Jespersen (1924) 1975: 349, Gili Gaya 1967 §219. II, RAE 1973: §3.19.4c, Banfield 1973: 3 , Alcina y Blecua (1975) 2001: §8.4.1, Maingueneau 1981: 101, Coulmas 1985: 43, Maldonado 1991: 30, Reyes 1993: 31, Alarcos 1999: §387, Gómez Torrego 2002: §3.3.4.2, entre otros.
} 
En esta estructura, que de acuerdo con Li no existe en todas las lenguas del mundo, ${ }^{53}$ S2 se encuentra integrado a S1 por medio de una conjunción. Numerosos especialistas han enfatizado en la naturaleza nexual de la subordinación objetiva que presenta esta forma de referir las palabras ajenas: Gili Gaya $^{54}$, la Real Academia, ${ }^{55}$ Alcina y Blecua,${ }^{56}$ Alarcos, ${ }^{57}$ Jespersen,${ }^{58}$ Banfield ${ }^{59}$ Maingueneau, ${ }^{60}$ Coulmas, ${ }^{61} \mathrm{Li}^{62}{ }^{62}$ Maldonado ${ }^{63}$ y Nølke, Fløttum y Norén ${ }^{64}$ son solo algunos ejemplos notables.

Varias son las conjunciones que, según se ha dicho, admite el discurso indirecto marcado: si, como, según y que, por ejemplo. ${ }^{65}$ Por tratarse de una de las voces conjuntivas de más alta frecuencia en el idioma, y por tanto en el discurso indirecto, no son pocos, sin embargo, los autores que confieren a esta última el carácter de única conjunción posible en cuanto marca de discurso indirecto. ${ }^{66}$ Desde luego, no es esa la posición asumida en este trabajo, aunque debe reconocerse que, en los titulares periodísticos, dicho nexo constituye la indicación de discurso indirecto más abundante y la única que se registra junto con verbos subordinantes expresos.

Tal como sucede con las demás marcas de retransmisión analítica, "la presencia de la conjunción que es un índice de que se desea presentar el

\footnotetext{
${ }^{53}$ Carecen de ella el navajo, el amárico y el páez, por ejemplo (Li 1986: 39).

${ }^{54}$ Gili Gaya 1967 §219. II.

${ }^{55}$ RAE 1973: $\$ 3.19 .4 c$.

${ }^{56}$ Alcina y Blecua (1975) 2001: §8.4.1.

${ }^{57}$ Alarcos 1999: $\$ 387$.

${ }^{58}$ Jespersen (1924) 1975: 349.

${ }^{59}$ Banfield 1973: 3.

${ }^{60}$ Maingueneau 1981: 101.

${ }^{61}$ Coulmas 1985: 43.

${ }^{62}$ Li 1986: 35.

${ }^{63}$ Maldonado 1991: 30.

${ }^{64}$ Nølke, Fløttum y Norén 2004: 74.

${ }^{65} C f$., entre otros, Gili Gaya 1967: §219. II, Reyes 1982: 13, R AE y AALE 2005: s. v. si.

${ }^{66}$ Por ejemplo, RAE 1973: \$3.19.4c, Maldonado 1991: 30, Van der Houwen 2000: 28, Gómez Torrego 2002: §3.3.4.2.
} 
D[iscurso]I[ndirecto] como traslación de un D[iscurso]D[irecto]". ${ }^{67}$ Esta marca, sin embargo, "no garantiza necesariamente que las relaciones deícticas [...] se recuperen de forma inequívoca". ${ }^{68}$ Por lo general acompañadas en lo oral por "una entonación especial, uniforme, de final descendente", ${ }^{69}$ estas construcciones pueden —desde la controvertida perspectiva de algunos- "introducir fragmentos sintácticos menores que la oración", 70 siempre y cuando constituyan "fragmentos oracionales" (es decir, enunciados gramaticalmente incompletos pero contextualmente interpretables): Dice que sí, dice que no, dice que mañana... ${ }^{72}$

De manera similar a lo que ocurre con el discurso directo, la selección concreta del verbo de habla puede especificar o no peculiaridades atribuidas por Loc 1 al acto de habla ajeno: como afirma Maingueneau, ${ }^{73}$ dichos verbos pueden referir el puro hecho de locución o añadir especificaciones al significado referencial básico, tales como la fuerza ilocucionaria, el modo de realización fónica, el valor de verdad o falsedad del enunciado secundario, o muchas otras.

(4) a. Chávez dice que EE.UU. provocó terremoto en Haití [COM 21/01/10: B11]

b. Interior advierte que todos los extranjeros deben ser inscritos [ELP 19/01/10: 15]

c. Unicef denuncia que 15 niños desaparecieron de varios hospitales [ELN 23/01/10: A10]

\footnotetext{
${ }^{67}$ RAE y AALE 2009: $\$ 43.10 \mathrm{~d}$.

${ }^{68} \mathrm{Ibid}$.

${ }^{69}$ Verdín Díaz 1970: 66.

${ }^{70}$ RAE y AALE 2009: $§ 43.9 p$.

${ }^{71}$ Maldonado 1999: 3575.

${ }^{72}$ No registro casos de este tipo en mi corpus. Las Academias interpretan elipsis en ejemplos como los mencionados, pero censuran la incorporación de interjecciones, propias del discurso directo, como sucede en las secuencias Dijo que hola y Dijo que icoño!, salvo "en la lengua oral relajada" (RAE y AALE 2009: §43.9q). Esta postura no es, en absoluto, unánime: autores como Spitzer (1946) y Girón Alconchel (1989: 75, 2006: 400) consideran que son estructuras mixtas. Desde mi perspectiva, es probable que se trate de formas mixtas con S1 en discurso indirecto marcado y $\mathrm{S} 2$ en discurso directo no marcado (véase el capítulo sobre formas mixtas).

${ }^{73}$ Maingueneau 1981: 101.
} 
d. Pide Marta que prevalezca el derecho [REF 21/02/05: 6A]

e. Diputado español exige que el FBI le pida disculpas [MER 20/01/10: A6]

f. Obama propone a Lula que coordinen ayuda humanitaria [MER 19/01/10: A4]

Conviene destacar — también aquí- que la selección de verbos subordinantes permite a Loc 1 imponer al lector su interpretación del acto de habla. En (4d), por ejemplo, Loc 1 describe el acto ilocucionario de Loc 2 -la mujer del entonces presidente de México- como una petición, sin que se trate de un acto originalmente performativo, al menos de acuerdo con la información contextual proveída por el mismo periódico, que, en discurso directo, es expresada de la siguiente manera: "El Presidente ya ha sido muy claro en ese sentido y yo no tengo más que aumentar en ese tema, más que este país necesita vivir en un Estado de derecho permanente" (REF 21/02/05: 6A). Este ejemplo también ilustra que existe una reformulación del supuesto enunciado original en S2. Precisiones similares pueden hacerse en los casos (4b), (4c), (4e) y (4f).

Puede observarse en todos los ejemplos de la serie (4) que, a pesar de la integración enunciativa que el discurso indirecto supone, la existencia de marcas deriva en una delimitación no ambigua entre las palabras que asume Loc 1 y el segmento cuyo contenido se atribuye a Loc 2: si bien el discurso indirecto se asocia convencionalmente con la existencia de una retransmisión analítica resultante de una incorporación enunciativa, en sus variedades marcadas se establece normalmente una delimitación cabal. El contenido de los enunciados representados en las oraciones subordinadas de (4a), (4b), (4c), (4d), (4e) y (4f) es lo único que se atribuye a los locutores secundarios. Así pues, las indicaciones formales de subordinación — verbos y conjunciones — aportan en esta estructura las instrucciones interpretativas por las que, en primer lugar, se distinguen claramente los niveles primario y secundario de la "escena 
enunciativa", ${ }^{74}$ y en segundo, $\mathrm{S} 2$ se decodifica como una reconstrucción analítica.

(5) Predice que economía crecerá un 9\% en 2010 [HOY 21/01/10: 2E]

Sirvan la serie (4) y el testimonio (5) para ilustrar, por último, que la configuración gramatical prototípica del discurso indirecto marcado registra, en mis materiales, las mismas formas de aludir a Loc 2 que, como indicadoras de la importancia conferida por Loc 1 a Loc 2, he descrito en el capítulo anterior. El locutor secundario de (4c) es un asesor del Unicef en Haití: opera, pues, una sinécdoque generalizante. En (5), en cambio, el sujeto tácito de la oración subordinada es el subdirector del Departamento de Previsiones Económicas del Gobierno chino.

Se encuentran titulares de este tipo en todos los periódicos de la muestra cuantificada, aunque con mayor frecuencia en los diarios Clarín, El País y El Comercio. La presencia de estas estructuras en La Opinión y La Nación es casi anecdótica, pues registro apenas uno o dos testimonios. Poco mayor que en estos dos últimos periódicos es la frecuencia de uso en las demás publicaciones $-E l$ Mercurio, El Universal, Hoy, El Tiempo y El Nacional-, pero en todos los casos se trata de proporciones muy bajas con respecto a la totalidad del corpus, pues, como ya hemos dicho, las formas marcadas del discurso indirecto son minoritarias en los diarios del mundo hispánico.

\subsubsection{Verbo expreso y conjunción elidida}

La conjunción subordinante se encuentra elidida en el 20,9\% (45/215) del total de casos de discurso indirecto marcado. Desde hace algún tiempo, los gramáticos

\footnotetext{
${ }^{74}$ Fonte 1999: 143.
} 
han identificado la elipsis de conjunción en este tipo de discurso ajeno y han calificado el fenómeno como "normal", siempre que se trate de verbos subordinantes que supongan 'voluntad', 'temor', 'sentimiento' u 'opinión' ${ }^{75}$

En fechas más recientes, las Academias ${ }^{76}$ han descrito las omisiones de conjunción subordinante en casos de subordinación sustantiva en función de si el verbo subordinado está en modo indicativo o subjuntivo. Según su descripción, admiten elipsis las estructuras con verbo subordinado en subjuntivo y verbo subordinante que expresa 'petición, mandato y otras formas de influencia' o bien 'voluntad' (esto último solamente en algunos casos, en particular si se manifiesta la actitud favorable del sujeto en relación con lo que ha de suceder). También se omite a veces la conjunción subordinante, añaden, cuando el verbo subordinado está en indicativo y el subordinante denota 'pensamiento y juicio'. Si bien aseguran que su uso era mucho más frecuente en los textos antiguos que en los modernos, admiten que estas formas de elipsis se atestiguan hoy en el lenguaje epistolar, en el jurídico, en el administrativo y "en otras variedades formales de la lengua escrita", ${ }^{77}$ pero siempre y cuando el verbo subordinante esté a su vez subordinado a otro: "En el español actual no se omite la conjunción si el verbo que la introduce no está subordinado". ${ }^{78}$

(6) a. Dicen Angelina Jolie y Brad Pitt viven una máscara matrimonial [HOY 18/01/10: 2D]

b. Micheletti afirma no será asesor de Porfirio Lobo [HOY 20/01/10: 16B]

c. Jiménez solicita cambien pena de muerte por cadena perpetua [HOY 26/01/10: 14A]

\footnotetext{
${ }^{75}$ Entre otros, Bello (1847) 1958: §982-984, Gili Gaya 1967: §219. II, Moliner 1975: s. v. que, RAE 1973: §3.19.4d, RAE y AALE 2005: s. v. que, §2.1.2, En 1931, la Real Academia sostenía: "La conjunción que puede omitirse, especialmente si el verbo [subordinado] está en subjuntivo" (RAE [1931] 1962: §380b).

${ }^{76}$ RAE y AALE 2009: $\$ \S 43.3 b-43.3 \mathrm{j}$.

${ }^{77}$ Ibid.: $\$ 43.3 b$.

${ }^{78}$ Ibid.: $\$ 43.3 \mathrm{~h}$.
} 
d. Amaro Jr. dice Filis no tienen para pagarle a Pedro [HOY 20/01/10: 5B]

e. Banamex prevé crezca 4\% el PIB [UNI 21/01/10: B5]

f. Dice Salinas Pliego asistirá a corte de EU [REF 25/02/05: NEG 18]

g. Exige Samuel Ruiz a Fox dé respuesta consciente a la CIDH [JOR 23/02/05: 35]

h. Rechaza VFQ haya una persecución política [LAP 22/02/05: 1]

Como puede verse, ninguno de los ejemplos de la serie (6) cumple la última condición. De hecho, en los 45 testimonios que recojo, el verbo subordinante es siempre el verbo principal de toda la secuencia. Es evidente, asimismo, que los verbos subordinantes de los titulares $(6 \mathrm{e})$ y $(6 \mathrm{~h})$, con verbo subordinado en modo subjuntivo, no denotan ni 'voluntad' ni 'petición, mandato u otras formas de influencia', y que los verbos principales de los encabezados (6a), (6b), (6d) y (6f), con el verbo subordinado en indicativo, tampoco expresan 'pensamiento o juicio'. ${ }^{79}$ Además, en (6g) y (6h) los verbos subordinados en subjuntivo no aparecen contiguos al verbo subordinante, como también aseveran las Academias para este tipo de casos. ${ }^{80}$

Al margen de disquisiciones puristas que en nada ayudarían a la descripción del corpus, parece que lo que motiva la formulación de este tipo de titulares no es otra cosa que la tendencia, especialmente notoria en determinados diarios, a elidir nexos y determinantes por evidentes razones de economía. En cuanto a la nocontigüidad de los verbos, recuérdese que ciertos diarios tienden asimismo a situar el verbo principal al principio del titular. Debo añadir que solamente he encontrado casos de discurso indirecto marcado con verbo expreso y conjunción elidida en periódicos dominicanos y mexicanos (los de la muestra cuantificada

\footnotetext{
${ }^{79}$ Según Maldonado (1999: 3575), en español se elide la conjunción subordinante "sólo cuando el verbo de la subordinada está en subjuntivo y el verbo principal, por su propio significado léxico, es un verbo prospectivo que concede a la completiva un valor de referencia al futuro [...]. Por ello, entre los verbos de decir, ni los de significado exclusivamente declarativo, ni los retrospectivos admiten la ausencia de la conjunción". Varios testimonios de la serie, como (6d), representan evidentes contraejemplos de esta descripción.

${ }^{80}$ RAE y AALE 2009: $§ 43.3 f$.
} 
proceden, casi todos, del diario Hoy y, alguno, de El Universal; los demás ejemplos son del corpus piloto).

Los casos sin conjunción subordinante expresa no integran la variedad de discurso indirecto marcado más abundante en los titulares periodísticos. Parece, además, que dicha configuración gramatical no es privativa de los encabezamientos, por cuanto los gramáticos, que tradicionalmente han desatendido la sintaxis periodística, la han venido señalando como usual desde hace mucho tiempo. Puesto que la cantidad de ejemplos que ofrecen mis materiales resulta insuficiente para extraer conclusiones de cierto rigor, solo es posible destacar las limitaciones de los estudios gramaticales para caracterizar este tipo de titulares, algunos de cuyos usos son a menudo censurados en obras con intención normativa. Por lo pronto, son necesarios estudios que confirmen si en verdad se trata de "una moda pasajera", "cada vez menos frecuente" 81 y exclusiva de la lengua escrita. ${ }^{82}$

\subsubsection{Conjunción expresa y verbo elidido}

Presenta elipsis de verbo subordinante solo el 1,9\% (4/215) del total de casos de discurso indirecto marcado. En este tipo de titulares, la conjunción es el único índice explícito de hipotaxis y de retransmisión analítica. Con tal función, registro usos de los nexos que y según.

(7) a. Que E. Salinas no fue asesinado en Huixquilucan [LAP 22/02/05: 10]

b. Que podría caer la acusación en PGJEM contra Mendoza Ayala [LAP 24/02/05: 9]

c. Que el padre de Lindsay Lohan amenazó con matarla [SOL 25/02/05: $3 / \mathrm{E}]$

\footnotetext{
${ }^{81}$ Moliner 1975: s. v. que; $c f$. Maldonado 1999: 3575.

${ }^{82}$ RAE 1973: §3.19.4d; $c f$. RAE y AALE 2009: §43.3b.
} 
En los testimonios de la serie (7), la presencia de la conjunción que al principio del titular señala claramente "un principio de subordinación sin verbo subordinante expreso". ${ }^{83}$ Como bien observa Gili Gaya, que puede comenzar "una oración aparentemente independiente, pero en realidad mentalmente subordinada". ${ }^{84}$ Estos ejemplos de oraciones declarativas refutan los señalamientos de algunos lingüistas que, categóricamente, niegan la existencia de este fenómeno en oraciones no interrogativas o exclamativas. ${ }^{85}$

Bello apunta que suelen acompañar a esta conjunción algunas elipsis de verbo "que hacen muy expresiva la frase" ${ }^{86}$ Sin emitir generalizaciones excluyentes, es posible decir que la sola presencia de esta conjunción, al principio del enunciado reproducido analíticamente, marca cierta distancia entre Loc 1 y el contenido del enunciado ajeno; es decir, Loc 1 no se compromete con las palabras de Loc 2. En estos casos, la conjunción que aporta una calificación evidencial ${ }^{87}$ de $\mathrm{S} 2$, pues añade la indicación de un origen de la información distinto de Loc 1 y, secundariamente, un valor de duda, negativa o desconfianza. Desde un punto de vista estrictamente formal, esto parece contraponerse a las observaciones, repetidas por ciertos tipólogos, ${ }^{88}$ alusivas a que el español solo puede marcar léxicamente la evidencialidad. ${ }^{89}$

\footnotetext{
${ }^{83}$ RAE 1973: $\$ 3.19 .4 e$.

${ }^{84}$ Gili Gaya 1967: §219. II. En realidad no dejan de sorprender las Academias cuando aseguran que las construcciones sin verbo subordinante e introducidas por que se emplean en ocasiones "como marca de discurso directo" (R AE y A ALE 2009: §31.1p; las cursivas son mías) y que "la presencia de la conjunción que es un índice de que se desea presentar el D[iscurso]I[ndirecto] como traslación de un D[iscurso]D[irecto]" (R AE y AALE 2009: §43.10d).

${ }^{85}$ Por ejemplo, Moliner 1975: s. v. que.

${ }^{86}$ Bello (1847) 1958: $\$ 995$.

${ }^{87}$ Cf. Chafe 1986.

${ }^{88} C f$. Lazard 2001, por ejemplo.

${ }^{89}$ Otro argumento en contra de dicha hipótesis es la existencia de condicionales con valor de potencial citativo (cf. infra).
} 
(8) a. El paro no llegará a cuatro millones, según Corbacho [ELP 11/01/09: 22]

b. ETA mantiene la extorsión al mismo nivel, según la patronal [ABC 08/01/09: 18]

c. Muertos en Haití son más de 112 mil, según reporte inicial [COM 24/01/10: A1]

d. Las cifras pueden ser mayores, según sondeo [UNI 23/01/10: A15]

e. 70 mil muertos ya han sido sepultados, según gobierno [MER 18/01/10: A7]

f. Se recuperó la industria, según el INDEC [CLA 23/01/10: 14]

Los titulares periodísticos presentan el uso de la partícula según, acompañada de una elipsis de verbo de habla, para indicar la presencia de una retransmisión analítica de las palabras de Loc 2, construcción esta que, además de ser típica del discurso periodístico, "se encuentra profusamente en el lenguaje hablado". ${ }^{90} \mathrm{La}$ palabra según, clasificada tradicionalmente como preposición, desempeña funciones conjuntivas en enunciados como los de la serie (8), pues la oración que afecta tiene su verbo en forma personal y no va encabezada por que..$^{91}$ Recuérdese que las preposiciones se diferencian de las conjunciones subordinantes en que estas últimas siempre subordinan oraciones con verbo en forma personal.

Autores hay ${ }^{92}$ que ya excluyen según del inventario de preposiciones. Una de las razones más convincentes es que esta partícula no rige caso oblicuo, sino nominativo (según $\{t u ́ \sim * t i\}$ ). Dicho comportamiento —evidente con los pronombres tónicos - se debe a que parece subyacer un verbo de habla subordinante (según tú < según dices tú $~ *$ según dices ti). ${ }^{93}$ Por cuanto según subordina, al menos en estos casos, una oración con verbo en forma personal a

\footnotetext{
${ }^{90}$ Reyes 1982: 13.

${ }^{91}$ Cf. Reyes 1982: 13, Gutiérrez Ordóñez 1986: 28, Pavón 1999: 588.

${ }^{92}$ Por ejemplo, Alarcos 1999: §284

${ }^{93}$ Para las Academias, este análisis "presenta el inconveniente de que introduce un tipo de elipsis extraño en el sistema gramatical español, ya que la identificación del elemento elidido está restringida léxicamente y no se recupera a partir del discurso previo" (RAE y AALE 2009: \$29.2f). Sin embargo, como veremos a continuación, no presenta pocas anomalías la función prepositiva que en estos casos le atribuyen a según.
} 
otra oración, parece claro que se trata de una conjunción subordinante. Además, a diferencia de las preposiciones, rechaza la alternancia entre frases nominales y oraciones subordinadas sustantivas introducidas por que: sin el apoyo $\sim \sin q u e$ haya el apoyo, frente a según Rodríguez *según que dice Rodríguez.

Algunos de estos rasgos, así como su naturaleza tónica -atípica tanto en conjunciones como en preposiciones-, parecen constituir restos de su origen latino. De acuerdo con Alvar y Pottier, esta palabra procede de un gerundio latino del verbo que significaba 'seguir', secundum (que podría traducirse como 'siguiendo a'), el cual "adquirió en latín tardío el valor de conjunción modal". 94 Debe concederse, no obstante, que hoy en día según posee un carácter especial, plurifuncional $^{95}$ y tendente en ocasiones a la indeterminación, a causa de la gradualidad y acumulatividad de los procesos de gramaticalización.

Sea como fuere, el segmento que contiene a esta partícula — S1 - "es modificador del modus epistémico y remite, polifónicamente, a una persona o entidad que se responsabiliza de la opinión". ${ }^{96}$ Evidentemente, es Loc 1 quien se distancia del contenido de las palabras de Loc 2, que aparecen analíticamente reformuladas en S2. En todos los titulares en discurso indirecto con la partícula según que he registrado, ya en el corpus cuantificado, ya en las sucesivas muestras piloto, el orden es siempre S2-S1: según nunca encabeza los titulares. ${ }^{97}$

\footnotetext{
${ }^{94}$ Alvar y Pottier 1983: $\$ 202.1$.

${ }^{95}$ Además de comportamientos conjuntivos y prepositivos, según posee usos adverbiales. Pavón (1999: 589), por ejemplo, hace notar que esta palabra puede tener autonomía sintáctica (como en un fragmento oracional: $-_{i}$ Lo harás? -Según), en cuyo caso la función desempeñada apuntaría más hacia la de un adverbio.

${ }^{96}$ Santos Río 2003: s. v. según, \$3.4.

${ }^{97}$ Acaso por esta razón López Hidalgo entiende que las construcciones con según se emplean en los titulares solamente cuando el periodista considera que "lo que se dice tiene prioridad frente a quien lo dice" (López Hidalgo 2009: 117).
} 
Es interesante advertir que, cuando la elisión del verbo es acompañada por la conjunción que, se omite también el agente de la enunciación originaria. En cambio, cuando la acompaña según, siempre se alude a Loc 2: por medio de correferencias propias, como en (8a), o impropias, como en los demás ejemplos. Recuérdese que, de acuerdo con el modelo del cuadrado ideológico, de Van Dijk, ${ }^{98}$ la omisión y los grados de detalle en la expresión responden a la ideología subyacente de Loc 1. En cualquier caso, la elisión del verbo de habla evita que Loc 1 exprese directamente su lectura del acto ilocucionario, pero no necesariamente su evaluación respecto de la fiabilidad de la información que fue expresada en el acto locucionario original.

Debo aclarar, finalmente, que los únicos cuatro casos presentes la muestra cuantificada son los últimos ejemplos de la serie (8). Esto significa que no fue cuantificado ningún titular en discurso indirecto marcado con verbo subordinante expreso y la conjunción que, como los de la serie (7). Estos encabezados son ciertamente muy escasos, pero interesantes desde el punto de vista del análisis cualitativo. También son relativamente pocos los titulares con según, pero pueden rastrearse sin problemas en la prensa de todas las ciudades consideradas.

\subsubsection{Con la preposición para}

Registro solamente seis titulares — publicados todos ellos en los diarios Clarín y El Universal - donde el contenido de las palabras ajenas es introducido por la preposición para seguida por una frase nominal. Estos testimonios representan apenas el 2,8\% (6/215) de los casos de discurso indirecto marcado.

Con este uso de para, ausente por lo general de las gramáticas tradicionales, se introducen "complementos nominales o pronominales que designan a la persona

${ }^{98}$ Van Dijk 2003. 
que sostiene cierto parecer". ${ }^{99}$ La preposición y su término conforman en este tipo de casos un adjunto periférico que, como sucede con todas las marcas de discurso indirecto, “es modificador del modus epistémico". 100

(9) a. Para el INDEC porteño, la canasta básica aumentó casi $70 \%$ en 3 años [CLA 24/01/10: 18]

b. Para el Gobierno, Pesce es ahora el jefe del BCRA [CLA 23/01/10: 6]

c. Para Carrió y De Narváez, Cobos no debe irse [CLA 22/01/10: 4]

(10) Para Favre, el Super Bowl no es su meta [UNI 21/01/10: D5]

Regresar a un Super Bowl no es la meta principal que llevó a Brett Favre a volver a la NFL con los Vikingos esta temporada, según comentó ayer el veterano quarterback de Minnesota.

Favre dijo que mientras un triunfo en el Super Bowl podría ser una perfecta manera de terminar su carrera [...], no validaría su carrera y esa no es la razón bajo la que se ha motivado durante esta temporada. [UNI 21/01/10: D5]

En todos los casos que recojo, la opinión introducida por la preposición y su término es siempre la reformulación analítica de las palabras de un Loc 2, como atestiguan el titular (10) y el fragmento del texto que encabeza. El cambio de eje deíctico es evidente en este caso, ya que el deportista habló sobre sí mismo y el adjetivo posesivo su que se observa en el encabezado remite claramente a él.

Si bien en estos casos la partícula para podría equivaler a según, no siempre pueden sustituirse una a la otra, y esto se debe, desde el punto de vista gramatical, a que la función de para es más claramente prepositiva que la de según, que, como hemos dicho, apunta más hacia una conjunción subordinante cuando constituye una marca de discurso indirecto (para $\{t i \sim * t u ́\}$, frente a según $\{* t i \sim t u ́\})$. Además, los datos de mi corpus sugieren una especialización

\footnotetext{
${ }^{99}$ RAE y A ALE 2009: §29.81. Cf. Lara Ramos et al. 2010: s. v. para, Fernández López 1999: 41, Seco, Andrés y Ramos 1999: s. v. para, §13. En ocasiones se ha descrito este uso como nocional causal de "tipo 'participación' (relajada)" con "implicación semántica del fin" (Riiho 1979: 49).

${ }^{100}$ Santos Río 2003: s. v. PARA SN[+hum].
} 
de uso en el discurso de los titulares, pues mientras según aparece siempre en encabezados con orden S2-S1, para figura en todos los casos en testimonios con el orden inverso.

Estos grupos preposicionales con para suelen interpretarse como tópicos, ${ }^{101}$ aunque ello no siempre sea tan claro en español actual como en otras lenguas, tales como el inglés ${ }^{102}$ y, particularmente, el francés. En este último idioma, la preposición pour tiene, entre otros usos muy frecuentes, el de "poner de relieve, generalmente al principio de la oración, el sujeto, el atributo o el objeto" ${ }^{, 103} \mathrm{y}$, en tales casos, es conmutable por expresiones como quant à o en ce qui concerne. ${ }^{104}$ Así, la secuencia Pour moi, je pense que... actualmente puede traducirse al español como Por lo que a mí respecta, pienso que... u otras expresiones similares, pero parece que difícilmente por Para mí, pienso que... Sin embargo, esto no siempre ha sido así. He aquí un testimonio de Cervantes:

Para mí, como yo esté harto, eso me hace que sea de zanahorias o de perdices. (CORDE 1615: s. v. para)

Puede decirse que, en este ejemplo, para mí hace oficio de por lo tocante a mí, por lo que respecta a mí, por lo que a mí concierne, en cuanto a mí, etcétera. Es, indudablemente, un tópico. En opinión de algunos, ${ }^{105}$ este uso de para constituye un préstamo del francés.

Si se asume la hipótesis de que en usos como (9a)-(9c) y (10) los grupos preposicionales con para son tópicos, habría que añadir una especificación que

\footnotetext{
${ }_{101}^{101}$ AE y AALE 2009: §39.8.q.

${ }^{102} \mathrm{El}$ inglés posee la expresión as for, que equivale a with respect to, in reference to, with regard to y similares. El primer testimonio conocido data del siglo XV (Meriam-Webster 2005: s. v. as).

103 "Pour sert à mettre en évidence, généralement en tête de la phrase, le sujet, l'attribut ou l'objet" (Le Bidois y Le Bidois 1971: §1877).

${ }^{104}$ Robert 2001: s. v. pour, §I.5, entre otros.

${ }^{105}$ Por ejemplo, Baralt 1945: s. v. para.
} 
asigne al término de esta preposición el valor del origen del contenido expresado, lo cual parece apuntar a una elipsis de verbo de habla o pensamiento, por lo menos en cierta etapa del proceso de gramaticalización. De esta manera, el titular (9c), por ejemplo, podría parafrasearse como En cuanto a Carrió y De Narváez, dicen que Cobos no debe irse.

De cualquier modo, tópico o no, galicismo o no, elíptico o no, este uso de para comporta en los titulares periodísticos una reformulación analítica de las palabras de Loc 2, y, por ende, constituye una variedad de discurso indirecto marcado.

\subsubsection{Condicional con valor de potencial citativo}

Las formas verbales en -ría, que Bello ${ }^{106}$ denominó pospretéritos, pueden expresar el futuro de un pretérito (pospretérito del tipo 1) o bien una posibilidad en cualquier época (del tipo 2): ${ }^{107}$ "En el pospretérito, mejor que en ninguna otra forma verbal, se funden los valores modales con los temporales". ${ }^{108}$ Este hecho ha causado no poca controversia entre los especialistas, como demuestra la cambiante nomenclatura: pospretérito, potencial, condicional potencial, condicional hipotético, futuro hipotético... La Real Academia Española ${ }^{109}$ lo ha considerado, incluso, un modo aparte. En la doctrina académica vigente, ${ }^{110}$ se denominan condicional simple las formas como cantaría (pospretérito para Bello) y condicional compuesto las secuencias como habría cantado (antepospretérito para Bello y potencial compuesto, condicional perfecto y

\footnotetext{
${ }^{106}$ Bello (1847) 1958: §634.

${ }^{107}$ Cf. Alonso y Henríquez Ureña 1939: $\$ 197$.

${ }^{108}$ Moreno de Alba 1985: 102.

${ }^{109}$ RAE (1931) 1962: $\$ 84$.

${ }^{110}$ RAE y AALE 2009: $\$ \$ 23.15$ y 23.16 .
} 
antefuturo hipotético para otros), ${ }^{111} \mathrm{y}$ ambas se consideran parte del modo indicativo.

Diversos son los matices modales del condicional simple o pospretérito que hemos llamado del tipo 2: probabilidad o posibilidad, eventualidad, hipótesis, conjetura y duda son solo algunos. ${ }^{12}$ Aquí interesa en especial uno muy especializado: "Dar a entender que se trata de aseveraciones ajenas, suposiciones cuya veracidad no se asegura o rumores no confirmados". ${ }^{113}$ En estos casos, como sostiene Lapesa, el pospretérito o potencial "se convierte en signo de discurso indirecto no atribuido concretamente a nadie, signo de enunciado ajeno e impersonal; el hablante nada afirma por su cuenta, como si se escuchara en un 'dicen que', 'se rumorea que' implícitos". ${ }^{114}$

Dicho valor, "propio del lenguaje periodístico", ${ }^{115}$ también está presente en algunos usos del condicional compuesto o antepospretérito ${ }^{116}$ y explica múltiples apelativos que las formas verbales en -ría han recibido: potenciales o condicionales "de información no asegurada", "de la conjetura", "del rumor", "de la cita", "del estilo indirecto". 117

Registro 56 casos de condicional simple (pospretérito) o compuesto (antepospretérito) con este valor asignado, al que llamaré arbitrariamente

\footnotetext{
${ }^{111} C f$. RAE (1931) 1962, RAE 1973, Gili Gaya 1967.

${ }^{112}$ Moreno de Alba 1985: 105, 2003: 56-57.

${ }^{113}$ Lapesa 1977: 227.

${ }^{114}$ Ibid.

${ }^{115}$ RAE y AALE 2010a: $\$ 23.8 \mathrm{f}$.

${ }^{116}$ En el condicional compuesto o antepospretérito se añade, sin embargo, un matiz perfectivo (Alonso y Henríquez Ureña 1939: §197, RAE 1973: §3.14.10a, M. Seco 1996: §12.1.3, por ejemplo; $c f$. RAE y AALE 2009: §23.16x).

${ }^{117}$ Lázaro Carreter (1976) 1998 y (1986) 1988, Lapesa 1977, Martínez Marín 1993, Reyes 1984 y 1994b, Casado Velarde 1995, Rojo y Veiga 1999, Hurtado 2003, entre otros. Las Academias consideran el "condicional del rumor" una variante del "condicional de conjetura" (RAE y AALE 2009: $\$ 23.15 \mathrm{~m})$.
} 
potencial citativo. Esta cifra representa el 26,1\% (56/215) de todas las retransmisiones indirectas marcadas: con poco más de la cuarta parte del total, los casos del potencial citativo integran la segunda variedad más abundante del discurso indirecto marcado en los titulares periodísticos (solamente superada por los casos de verbo y conjunción subordinantes explícitos). Considero que se trata de reformulaciones analíticas marcadas porque el morfema flexivo -ría constituye una marca de discurso ajeno, ${ }^{118}$ en conformidad con la definición que he asumido del término, ${ }^{119}$ y porque lo acompañan ciertas transformaciones deícticas. $^{120}$

(11) a. Venezuela doblaría en reservas a A. Saudí [тро 24/01/10: 1-6]

b. Sector construcción habría crecido 5,2\% [COM 19/01/10: B4]

c. Asaltos a agricultores de la periferia capitalina serían ejecutados por la misma banda [MER 20/01/10: C9]

d. Habrían unos 150,000 muertos [HOY26/01/10: 14B]

e. Altura de los bebés determinaría cuánto ganarán de grandes [SOL 23/02/05: 17/A]

f. Habría utilizado la CIA un Boeing 737 para transportar a presuntos terroristas [SOL 21/02/05: 15/A]

Según la información contextual, el contenido noticioso de los titulares (11a) a (11f) proviene de las siguientes fuentes: el Servicio Geológico de Estados Unidos, un analista financiero del banco canadiense Scotiabank en Perú, un funcionario de la policía chilena, el ministro de salud haitiano, unos científicos finlandeses y un reportero de la revista Newsweek, respectivamente. Puede advertirse que la presencia del morfema -ría neutraliza una aparente modalidad constativa de necesidad dinámica y la sustituye, en la actualización del discurso, por valores inferenciales de posibilidad epistémica. En otras palabras, Loc 1 pone en duda lo que Loc 2 aparentemente ha constatado.

\footnotetext{
${ }^{118}$ Para algún autor, no obstante, estos casos no están definidos "por ningún rasgo formal" (Maldonado 1999: 3553).

${ }^{119}$ Givón 1995: 28.

${ }^{120}$ Claro está que la adición del morfema - ría a menudo supone también la sustitución del morfema de tiempo correspondiente a la forma transpuesta del supuesto enunciado original.
} 
Es por ello que estos empleos de estas formas verbales han sido descritos como "el condicional del rumor, de lo que no consta fehacientemente". ${ }^{121} \mathrm{Se}$ usa a menudo en el discurso periodístico "para presentar las informaciones de forma cautelosa o dar noticias no suficientemente contrastadas". ${ }^{22}$ En los titulares, ambas formas verbales provocan "una sensación permanente de indefinición, de acción no cumplida y de condición no cumplida", ${ }^{123}$ con la cual el periodista se distancia del contenido y reduce su responsabilidad: "Si este tipo de secuencias está tan frecuentemente en boca de los periodistas es porque con ellas evitan responsabilidades legales". ${ }^{124}$ Todo ello resulta evidente en el siguiente titular y en los primeros párrafos del texto que encabeza:

(12) Se habría cancelado el Festival de cine del DF [UNI 24/01/10: K8]

Sólo rumores y desconocimiento es lo que priva en estos momentos acerca del 7 Festival Internacional de Cine Contemporáneo de la ciudad de México, que presuntamente se canceló por cuestiones financieras.

Claudio Sánchez, director de mercadotecnia de Cinemex, empresa creadora del encuentro cinematográfico, sólo dijo vía telefónica: - “ ¡Ah caray! No sé todavía nada, déjame checarlo”.

Raquel Cajiga, directora del certamen, no pudo ser localizada hasta el cierre de esta edición. Su celular tenía puesto el buzón de no contesta. Los responsables de los medios tampoco fueron encontrados y en las oficinas del poderoso corporativo se encontraba la operadora automática.

La noticia, que comenzó a circular vía Facebook por unos usuarios, sorprende, pues apenas en noviembre pasado se dieron a conocer los primeros detalles de la nueva edición. [UNI 24/01/10: K8]

Es preciso aclarar, sin embargo, que no siempre se trata estrictamente de rumores o información no confirmada. En el contexto del siguiente titular, que retomo de

\footnotetext{
${ }^{121}$ Lázaro Carreter (1976) 1998: 95.

${ }^{122}$ RAE y AALE 2009: $§ 23.15 \mathrm{~m}$.

${ }^{123}$ Barriga 1997: 114.

${ }^{124}$ Bosque 1990: 28.
} 
la serie (11), puede constatarse que el origen del contenido está perfectamente definido: es un prestigioso organismo científico estadounidense. Como bien observa Lapesa, "en el lenguaje periodístico de hoy es frecuente que no se mencionen el opinante, la fuente informadora ni la hipótesis restrictiva, y que se encomiende sin más al condicional la función de dar a entender que se trata de aseveraciones ajenas". 125

(11a) Venezuela doblaría en reservas a A. Saudí [TPO 24/01/10: 1-6]

Un reciente estudio del Servicio Geológico de E.U. (USGS) calcula que Venezuela tiene prácticamente el doble de reservas de petróleo que Arabia Saudí. Según el informe, mientras que en la faja del Orinoco del vecino país existen 513.000 millones de barriles de petróleo extraíbles, casi el doble de lo que se estimaba, el país Árabe tiene oficialmente 266.000 millones. [TPO 24/01/10: 1-6]

Autores hay, como Lázaro Carreter, ${ }^{126}$ que censuran esta innovación morfosintáctica — característica del discurso periodístico, aunque no privativa de este- ${ }^{127}$ por considerarla incorrección galicista. ${ }^{128}$ Otros, por el contrario, reivindican su uso arguyendo legítimas necesidades comunicativas. ${ }^{129}$ Otros más — periodistas siempre — admiten que en su gremio se cometen excesos, pero "sin que haya la necesidad de abolir el condicional". ${ }^{130}$ En cualquier caso, debe reconocerse que esta forma gramaticalizada de la evidencialidad cumple, de manera muy económica, específicas funciones de distanciamiento en el discurso de los titulares, y muy a menudo constituye también "un eufemismo dictado por la voluntad de estilo del periodista". ${ }^{131}$

\footnotetext{
${ }^{125}$ Lapesa 1977: 227.

${ }^{126}$ Lázaro Carreter (1976) 1998: 95 y (1986) 1998: 386.

${ }^{127}$ De acuerdo con Reyes (1994b: 33), se encuentra también en otros textos de registro igualmente formal.

${ }_{128}$ Para un estudio del tema en lengua francesa, $c f$. Maingueneau 1981: 116-122, por ejemplo.

${ }^{129}$ Por ejemplo, Martínez Marín 1993: 140-141, Hurtado 2003: 47.

${ }^{130}$ Di Bello y Sapegno 2003: 57.

${ }^{131}$ Romero Gualda 1991: 548. Cf. Barriga 1997.
} 
Con fundamento en el principio de considerar no noticiosa la información incierta, y no en criterios de corrección lingüística, se proscribe en los libros de estilo de algunos diarios, como El País y El Universal, toda expresión de modalidad epistémica en los encabezados: "Se prohíbe terminantemente el uso de expresiones en el titular — también restringidas en los textos- como 'podría', 'no se descarta', 'al parecer', 'posible', 'probable' y otras similares". ${ }^{132}$ A pesar de ello, se rastrean casos de potencial citativo en casi todos los diarios analizados, posean o no libros de estilo (aunque es verdad que son más frecuentes en El Comercio, El Mercurio, El Tiempo y La Nación). ${ }^{133}$ De hecho, del diario El Universal —donde según su libro de estilo se evita "la fórmula hipotética podría, puede, probable, sería, etcétera"-—, ${ }^{134}$ recojo nada menos que el testimonio (12).

\subsection{Discurso indirecto no marcado}

En el capítulo anterior quedó dicho que bajo la denominación "estilo indirecto libre" —acuñada por Bally ${ }^{135}$ hace ya muchos años— se han venido agrupando las modalidades de reproducción discursiva que no se ajustan estrictamente a los patrones estereotipados de las variedades marcadas: "La forma situada entre el

\footnotetext{
${ }^{132}$ El País 2003: 53. $C f$. Grijelmo 2003: 463-464.

${ }^{133}$ Según Hernando Cuadrado (2000: 25), este empleo del condicional o pospretérito ha experimentado en los últimos años "un cierto retroceso". No aporta datos de frecuencias relativas de uso.

${ }^{134}$ El Universal 2004: 31.

${ }^{135}$ Bally 1912. Si bien en 1912 Bally propuso esa denominación y atrajo la atención de los lingüistas, desde años atrás ya se había comenzado, sobre todo desde la perspectiva de la teoría literaria, a tratar el problema que plantea la reducción del amplio campo del discurso ajeno a ciertas formas marcadas de los discursos directo e indirecto: de acuerdo con Verdín Díaz (1970: 12-16), antes de Bally ya habían percibido el problema autores como Tobler, Kalepky, Lorck, Haas, Mennicken, Spitzer, Laftman y Herdin (en Alemania), y Clédat, Proust, Thibaduet, Lips, Legrand y Brunot (en Francia).
} 
estilo directo y el indirecto se llama estilo indirecto libre", ${ }^{136}$ dicen Leech y Short, por ejemplo. Lo mismo se lee incluso en el conocido estudio monográfico de Verdín Díaz sobre el tema: "El estilo indirecto libre está en el medio precisamente del estilo directo y del indirecto puro". ${ }^{137}$ Esta solución, más o menos matizada por algunos autores —especialmente del ámbito francés y anglosajón-, ${ }^{138}$ se originó en el trabajo de $\operatorname{Lips}^{139}$ y ha sido durante mucho tiempo la única respuesta planteada ante las carencias que conlleva la clasificación dual del discurso ajeno. ${ }^{140}$ Aunque menos incompleto que su antecesor, el arraigado modelo tripartito —estilos directo, indirecto e indirecto libre - también resulta insuficiente para caracterizar adecuadamente los titulares periodísticos: en primer lugar, porque habitualmente confunde en una misma categoría todas las formas no marcadas de reproducción discursiva (pues de hecho suele definirse como todo aquello que no se ajusta a los patrones estereotipados de los discursos directo e indirecto), ${ }^{141} \mathrm{y}$, en segundo, porque excluye las variedades del discurso ajeno que no suponen reproducción discursiva. Volveré a este último asunto en el capítulo siguiente.

Si bien en su Nueva gramática las Academias incorporan lo que denominan "discurso directo libre" (el cual definen por la ausencia de verbos de habla u “otras marcas lingüísticas"), mantienen la definición de "discurso indirecto libre" como una mayor combinación de "los rasgos del discurso directo y del discurso indirecto", propia del texto literario y caracterizada por "alternar los centros

\footnotetext{
136 "The form in between DS [direct speech] and IS [indirect speech] is called free indirect speech (FIS)" (Leech y Short 1981: 325).

${ }^{137}$ Verdín Díaz 1970: 10.

${ }^{138} C f$., entre muchísimos otros, Strauch 1974, Bruña Cuevas 1990, Dehennin 1994.

${ }^{139}$ Lips 1926: 51.

${ }_{140}$ Persiste en, por ejemplo, RAE (1931) 1962: §382, Gili Gaya 1967 §219.II, Partee 1973, Comrie 1986, Li 1986 y Hand 1991; cf. Todorov (1968) 1975: 60. Para una revisión histórica de las investigaciones seminales sobre el estilo indirecto libre, véase Verdín Díaz 1970: 9-16.

${ }^{141} C f$., por ejemplo, Bally 1912, Jespersen (1924) 1968: 349, Genette (1972) 1989: 231, Todorov (1972) 2000: 347-348, Banfield 1973: 10-13, RAE 1973: §3.19.4b, Wierzbicka 1974: 294-297, Alcina y Blecua (1975) 2001: §8.4.1.1, entre otros.
} 
deícticos que corresponden al narrador y a los personajes del texto narrado". ${ }^{142}$ Como veremos más adelante, esta definición no resulta operativa para describir nuestro corpus, ya que en ninguno de los más de dos mil casos considerados para este capítulo se observa tal alternancia (el eje deíctico es siempre el de Loc 1).

Desde luego, algunas de las diversas concepciones del estilo indirecto libre pueden resultar útiles para nuestros objetivos, como lo es hasta cierto punto la del propio Verdín Díaz, quien define como "ley general del estilo indirecto libre" la "falta de verdadero verbo introductor y transposición tanto verbal como pronominal o adverbial en tercera persona". ${ }^{143}$ Sucede, sin embargo, que la especificación "libre" se refiere precisamente a esa naturaleza no regida por verbo subordinante, ${ }^{144}$ lo cual presupone la oposición con una variedad "no libre", es decir, con verbo introductor, y ya hemos visto que los verbos de habla subordinantes no son más que parte de todo un grupo de marcas que denuncian retransmisiones analíticas. Además, por varios motivos, el uso del término "estilo indirecto libre" está claramente asociado al análisis de la narrativa literaria, en particular en cuanto grupo de técnicas empleadas para representar situaciones cercanas al monólogo interior. Así, por ejemplo, Reyes asegura que se trata exclusivamente de "un fenómeno del lenguaje literario" "que presenta los contenidos de la conciencia de un personaje". ${ }^{145}$ Salta a la vista, pues, la incongruencia con los propósitos de esta investigación.

Alejándome de la tipificación habitual, distingo las formas no marcadas de la representación discursiva (directas e indirectas) con base en el eje deíctico evidenciado por el texto: las considero, por tanto, variedades de los discursos

\footnotetext{
${ }^{142}$ RAE y AALE 2009: §43.9d. $C f$., entre otros, Strauch 1984.

${ }^{143}$ Verdín Díaz 1970: 149. Cf. Lips 1926.

${ }^{144}$ Bally 1912: 550.

${ }^{145}$ Reyes 1994a: 610.
} 
directo e indirecto, y no una categoría aparte. ${ }^{146}$ Cuando Loc 1 reformula analíticamente el supuesto enunciado de Loc 2 desde la perspectiva de su propia situación enunciativa, hablamos de discurso indirecto, y se especifica como no marcado cuando carece de indicaciones explícitas de ello.

Diversos son los autores que han advertido la necesidad de distinguir las formas que no ostentan indicaciones explícitas de una reproducción discursiva. ${ }^{147}$ Incluso se han sugerido varias denominaciones para lo que aquí se ha llamado discurso indirecto no marcado: "estilo cuasi-indirecto" u "oratio cuasi obliqua", 148 "estilo indirecto encubierto" o "enmascarado", 149 discurso o estilo "indirecto no conjuncional", 150 "estilo indirecto implícito", ${ }^{151}$ discurso o estilo "cuasi-directo". ${ }^{152}$ Todas estas propuestas han surgido como respuesta a las carencias que presenta el modelo tripartito tradicional a la hora de caracterizar las formas de actualización discursiva no marcada.

Hemos dicho que, como toda forma de discurso indirecto, el no marcado presenta una retransmisión analítica y, por consiguiente, ciertas transposiciones deícticas. La existencia de ello, sin embargo, no se denuncia explícitamente en el texto: la expresión del enunciado original no ostenta la adición de formas que sugieran esa interpretación. En otras palabras, el discurso indirecto no marcado se caracteriza, a reserva de lo que diremos en seguida, por la transposición de los deícticos exofóricos ${ }^{153}$ y por la ausencia de una oración subordinante que enmarque el

\footnotetext{
${ }^{146} C f$. Hickmann 1993: 71.

${ }^{147}$ Por ejemplo, Rivarola y Reisz de Rivarola 1984, Coulmas 1986 y 1994, Mathis y Yule 1994, Reyes 1994a y 1994b, Fairclough 1995a, Nølke, Fløttum y Norén 2004: 61.

${ }_{148}$ Reyes 1984.

${ }^{149}$ Reyes 1994b.

${ }^{150}$ Rivarola y Reisz de Rivarola 1984.

${ }^{151}$ Reyes 1994a.

${ }^{152}$ Coulmas 1986.

${ }^{153}$ Brecht 1974.
} 
contenido citado. ${ }^{154}$ En todos los casos, el contenido del enunciado original se expresa analíticamente en un segmento con independencia sintáctica.

Es necesario insistir, no obstante, en que la deixis personal no necesariamente experimenta transposiciones cuando el enunciado originario alude a entidades que no están presentes en el cuadro figurativo de la enunciación: en principio, si una entidad no participa directamente en el acto de enunciación primaria o secundaria, estará representada por formas de tercera persona, ya sea en el enunciado original o en sus reformulaciones analíticas. Como diría Benveniste, ${ }^{155}$ toda entidad que no participe en el cuadro figurativo de la enunciación - primaria o secundaria— quedará representada siempre por la "no-persona gramatical". En estos casos, la reformulación analítica es revelada gracias a información contextual y, por supuesto, a la deixis temporal y espacial. ${ }^{156}$

Hickmann ${ }^{157}$ observa que el discurso indirecto no marcado es frecuente en el habla cotidiana. De hecho, como sugiere Reyes, un análisis de esta variedad de discurso ajeno "muestra recursos claves de textos tan disímiles, al parecer, como las noticias de prensa, las conversaciones cotidianas, los textos teóricos". ${ }^{158}$ En su estudio exploratorio sobre el discurso ajeno en la prensa, Slembrouck ${ }^{159}$ ya advertía el uso reiterado de formas indirectas no marcadas.

A esta manera de actualizar lo dicho por otro corresponde el 55,3\% (2041/3689) del total de mi corpus, cifra que representa el 90,5\% (2041/2256) de todos los

${ }^{154} C f$. Chatman (1978) 1990: 216, Leech y Short 1981: 325, Reyes 1982: 10, 1994a: 594 y 1994b: 20, Nølke, Fløttum y Norén 2004: 77.

${ }^{155}$ Benveniste (1966) 2001.

${ }^{156}$ Cf. Banfield 1973: 10, Reyes 1984: 198 y 1994b: 18, Hickmann 1993: 71, Coulmas 1994: 3554, Nølke, Fløttum y Norén 2004: 66.

${ }^{157}$ Hickmann 1993: 65.

${ }^{158}$ Reyes 1984: 198.

${ }^{159}$ Slembrouck 1986: 95-100. 
casos de reproducción analítica. Es, sin lugar a dudas, la variedad de discurso ajeno más usual en los encabezados de la prensa del ámbito hispánico.

(13) a. Pelusso quiere a todos [MER 23/01/10: D4]

b. García Márquez está feliz en Cartagena [ELN 23/01/10: D8]

c. Uribe quiere evitar la impunidad de los militares acusados de asesinato [ELP 22/01/10: 7]

d. BRIAN CUSHING ESTARÁ AUSENTE DEL PRO BOWL [OPI 23/01/10: 7C]

e. A Pablo Barrera sólo le interesan los 3 puntos [UNI 20/01/10: D3]

f. Jessica nunca ha hecho dieta [HOY 26/01/10: 2D]

Como en todas las formas no marcadas, no es sino gracias al contexto que puede detectarse la existencia de una heteroglosia discursiva. ${ }^{160}$ Como señala Hickmann, ${ }^{161}$ el contexto funciona, en estos casos, como maraco de la cita: una lectura que no lo tome en cuenta - habitual en los consumidores de periódicos, según Emig ${ }^{162}$ Eco, ${ }^{163}$ Casado Velarde ${ }^{164}$ y Hurtado ${ }^{165}$ — probablemente dé como resultado la interpretación de un acto asertivo de Loc 1 (es decir, del periodista). Los locutores secundarios de (13a) a (13d) son, respectivamente, el entrenador del equipo de fútbol de la Universidad de Chile, Gerardo Pelusso; el escritor colombiano Gabriel García Márquez; el presidente de Colombia, Álvaro Uribe; el jugador de fútbol americano Brian Cushing, el futbolista mexicano Pablo Barrera y la actriz Jessica Alba. Ilustremos el testimonio (13a) con las primeras líneas de la nota informativa que encabeza (las negrillas son mías):

(13a) Pelusso quiere a todos [MER 23/01/10: D4]

Miguel Pinto encendió las alarmas en el Caracol Azul. "Me están viendo un par de equipos en Italia. Si llega alguna oferta interesante me puedo ir al mejor postor", indicó el arquero de la U.

\footnotetext{
${ }^{160}$ Collins 2001.

${ }^{161}$ Hickmann 1993: 65; $c f$. Reyes 1994b: 19.

${ }^{162}$ Emig 1927.

${ }^{163}$ Eco 1977.

${ }^{164}$ Casado Velarde 1984.

${ }^{165}$ Hurtado 2003.
} 
Gerardo Pelusso recogió de inmediato las palabras del golero y dio a conocer su preocupación ante la eventual partida. "Es una preocupación para todos, no porque se trate de Miguel Pinto, quien es el capitán del equipo y tuvo una temporada fantástica. Quiero tener a todos los jugadores, no tener lesionados, y es parte del juego y él tiene la preocupación que tienen varios. La disposición mía es trabajar con el plantel que tengo y ojalá que no se vaya ninguno. Hay un momento para todo. Comienza el campeonato y este es el equipo que tenemos", cerró Pelusso. [MER 23/01/10: D4]

Una comparación del titular con el segmento reproducido en discurso directo marcado revela la existencia de una retransmisión analítica: puede apreciarse que Loc 1 interpreta y reformula las palabras de Loc 2. La transformación deíctica es evidente: el quiero del discurso directo es sustituido por quiere. Fenómenos análogos están presentes en la codificación lingüística del resto de titulares de la serie.

Los encabezados de la siguiente serie aluden a las palabras del presidente interino de Honduras, Roberto Micheletti, cuando anunció que abandonaría el despacho presidencial en Tegucigalpa. El cotejo de los ejemplos bajo (14) con el fragmento de una de las notas informativas denuncia procesos de reformulación analítico-temática, resultante siempre de interpretaciones de re, que son, como hemos dicho, propias del discurso indirecto. Es importante advertir que, de acuerdo con los textos que los titulares encabezan, el acto ilocucionario de Loc 2 apuntó al anuncio de una acción y que, sin embargo, en los titulares se refiere dicha acción como constatada por Loc 1. En otras palabras, con la ausencia de marcas formales de retransmisión se omite la expresión de lo que Palmer denominó "modalidad citativa", ${ }^{166}$ lo cual supone normalmente un compromiso de Loc 1 con respecto al valor de verdad del contenido de las palabras atribuidas a Loc 2 .

\footnotetext{
${ }^{166}$ Palmer 1986.
} 
(14) a. Micheletti abandona despacho presidencial [UNI 22/01/10: A28]

b. Honduras: Micheletti se va pero no renuncia [CLA 22/01/10: 25]

c. Micheletti deja Palacio y gobernará desde su casa [HOY 22/01/10: 14B]

"Este es mi último día en la presidencia... me retiro a mi casa por la paz de la nación y porque no quiero ser un obstáculo al nuevo gobierno", dijo ayer Micheletti en una entrevista.

Pero avisó: "No renuncio del cargo, sólo me alejo temporalmente" y agregó que "retornará si las circunstancias lo ameritan y la patria lo exige", advirtió. [CLA 22/01/10: 25]

En todos estos encabezados, la expresión del enunciado original goza de independencia sintáctica: lo parece confirmar la ausencia de concordantia temporum. La ausencia de cambios de conjugación indudablemente atribuibles a concordancia de tiempos en más de dos millares de testimonios sugiere, entre otras cosas, que el discurso indirecto no marcado dista de ser, al menos en español, el simple resultado de omitir la oración subordinante que identifica al discurso indirecto marcado, conforme aseguran Chatman ${ }^{167}$ y Leech y Short, ${ }^{168}$ por ejemplo.

Como hemos dicho, la ausencia de indicaciones del cambio de nivel discursivo ocasiona que, en principio, los contenidos expresados originalmente por Loc 2 parezcan de la autoría original de Loc 1. Así, por ejemplo, la interpretación que deriva de la sola lectura de los encabezados de la serie (15) apunta a un origen de los contenidos en Loc 1, pero en realidad el periodista únicamente retransmite en el titular, indirectamente y sin marcas formales, las palabras de un Loc 2. Los locutores secundarios de (15a) a (15d) son, respectivamente, un asesor legal de Manuel Zelaya, Barack Obama, el ministro del Interior de Paraguay y unos pediatras investigadores.

\footnotetext{
${ }^{167}$ Chatman (1978) 1990: 216.

${ }^{168}$ Leech y Short 1981: 325.
} 
(15) a. Zelaya decidirá en 10 días si se va del país [LAN 18/01/10: 38A]

b. Plan educativo recibe millones [OPI 20/01/10: 6A]

c. Subversivos liberan a ganadero secuestrado [COM 19/01/10: B11]

d. Leche materna favorece salud mental del niño [ТРО 20/01/10: 2-2]

Esta conjunción discursiva ${ }^{169}$ suele producir una superposición de los puntos de vista de Loc 1 y de Loc 2, salvo — desde luego- en los casos de discurso bivocal de orientación múltiple, ${ }^{170}$ que se presentan cuando Loc 1 actualiza las palabras ajenas con un sentido distinto para manifestar una postura discordante, como en la ironía.

Por su naturaleza no histriónica, el discurso indirecto no marcado permite conceptuar a Loc 2 como participante en la representación de su propio discurso, como sucede en los ejemplos de las series (13) y (14). Puede ocurrir, por el contrario, que el declarante no esté representado en la expresión de su enunciado, pero cuya identidad pueda recuperarse del contexto lingüístico, como en los casos bajo (15), o bien que no figure explícitamente ni en el titular ni en su contexto lingüístico, pero que en este último se sugiera la existencia de una heteroglosia discursiva. Dados los procedimientos diferenciadores que la teoría del conocimiento exige, la descripción de estas variantes del discurso indirecto no marcado, complejas por naturaleza, requiere la adopción de métodos heterogéneos que tomen en consideración los diversos factores concurrentes en la codificación lingüística de los titulares periodísticos. A todo ello dedicaré las siguientes secciones de este capítulo.

\footnotetext{
${ }^{169}$ Rivarola y Reisz de Rivarola 1984: 152.

${ }^{170}$ Bajtín (1963) 1986: 280-291.
} 


\subsubsection{Declarante representado en el texto}

Como bien sugería Davidson, ${ }^{171}$ el discurso indirecto debe analizarse en función de las relaciones que el enunciado establece entre el locutor secundario, el enunciado original y el locutor primario. ${ }^{172}$ Ya hemos advertido que, en sus formas no marcadas, el discurso indirecto permite conceptuar a Loc 2 como actor en la representación analítica de su propio discurso; es decir, esta forma de discurso ajeno admite que Loc 1 transforme el enunciado original de manera que exhiba a Loc 2 no como fuente de la información proporcionada, sino como participante en la acción, estado o proceso del que el mismo Loc 2 ha dado cuenta. A excepción de los casos de pretendida falsedad, esto supone, desde luego, que el locutor secundario guarde efectivamente cierta relación con la información referida, además de la de ser su origen.

Este fenómeno ocurre en el 29,5\% (602/2041) de todos los casos de discurso indirecto no marcado de mi corpus. Tales reformulaciones analíticas presentan estructuras oracionales en el 99\% (596/602) de los casos; el 1\% (6/602) restante corresponde a frases. En conformidad con los planteamientos de Lope Blanch, entiendo por oración un sintagma conformado por dos miembros en relación predicativa, ${ }^{173}$ y por frase, una "expresión autosemántica constituida por un elemento nuclear o en torno a un elemento nuclear [...], pero de estructura no oracional" ${ }^{174}$. Como señala Alarcos, las frases "carecen del núcleo verbal en que se cumple la relación predicativa". ${ }^{175}$

\footnotetext{
${ }^{171}$ Davidson 1968.

${ }^{172} \mathrm{Si}$ bien dicho autor aludía solo a las formas marcadas —objeto de atención preferente para casi todos los especialistas-, este planteamiento resulta especialmente provechoso para resolver algunas dificultades que presenta la descripción de las formas no marcadas.

${ }^{173}$ Lope Blanch 1979; $c f$. RAE y AALE 2009: §1.13a.

${ }^{174}$ Lope Blanch 1983: 28.

${ }^{175}$ Alarcos (1994) 1999: §456.
} 


\subsubsection{Oraciones}

Para Fillmore, ${ }^{176}$ la estructura profunda de toda oración, en cuanto nivel que trasluce su interpretación semántica, se compone de un predicado que relaciona uno o varios sintagmas nominales vinculados con un determinado caso o papel semántico, hasta cierto punto independiente de la función sintáctica superficial que desempeña. Puede decirse que los casos, en el sentido propuesto por este autor, son significados presumiblemente universales que se asignan a los constituyentes nominales relacionados por un verbo y que corresponden al papel que la entidad designada por el sintagma nominal lleva a cabo en el estado, acción o proceso que la oración representa.

En su etapa inicial, esta teoría consideraba seis casos concretos: agentivo, dativo, locativo, instrumental, objetivo y factivo. En este trabajo no me referiré sino a los tres primeros, pues son los únicos aptos para caracterizar el tratamiento que se da a Loc 2 en los titulares en discurso indirecto no marcado: los encabezados en esta variedad del discurso ajeno y con estructura predicativa presentan el sintagma nominal que alude al declarante únicamente en los casos agentivo, dativo y locativo. Para la definición del resto, solo asignables a entidades inanimadas, me remito a Fillmore. ${ }^{177} \mathrm{Si}$ bien es cierto que esta teoría ha sufrido numerosas modificaciones desde su nacimiento — sobre todo en el número de casos-, en poco o nada se alteran las conclusiones de la presente investigación.

\footnotetext{
${ }^{176}$ Fillmore 1968.

${ }^{177}$ Ibid.
} 


\subsection{Alusión a Loc 2 en caso agentivo}

Se dice que un constituyente nominal está en caso agentivo cuando designa, en la oración, a la entidad animada que instiga, controla y dirige voluntariamente el estado, acción o proceso representado. ${ }^{178} \mathrm{El}$ sintagma nominal correspondiente a Loc 2 desempeña este papel semántico en 428 testimonios, que integran el 71,8\% (428/596) de los encabezados oracionales en discurso indirecto no marcado que aluden en el texto a Loc 2.

(16) a. Piñera mantendrá la política exterior [ELN 19/01/10: A10]

b. Presidente Chávez perdona deuda [HOY 26/01/10: 11B]

c. Cristina suspendió la visita a China para no dejar a Cobos en el poder [CLA 20/01/10: 8]

d. TOM HICKS DECIDE VENDER LOS VIGILANTES [OPI 24/01/10: 2C]

e. Un cordobés hace mapas gratis para salvar vidas [CLA 21/01/10: 19]

Los sintagmas nominales Piñera, presidente Chávez, Cristina, Tom Hicks y un cordobés fungen como agentes en los titulares (16a) a (16e), respectivamente, y, según la información contextual proveída por el mismo periódico, su referente coincide con Loc 2: texto y contexto presentan a las entidades designadas por estas frases como agentes, ya de lo expresado por el verbo, ya del acto de habla originario.

El hecho de que se encuentre en este caso la gran mayoría de alusiones a los declarantes sugiere que existe cierta tendencia a formular en discurso indirecto no marcado las declaraciones cuyo contenido apunta a acciones o procesos instigados y dirigidos por Loc 2: en principio — pues nada impide la codificación de interpretaciones analíticas dolosas-, el exhibir a Loc 2 como participante en

${ }^{178}$ Ibid. 
la situación representada supone que este realmente forma parte de ella, al menos desde la perspectiva de Loc 1, y que el locutor primario le concede suficiente autoridad como para comprometerse con el contenido representado.

\subsection{Alusión a Loc 2 en caso dativo}

En la primera etapa de su teoría, Fillmore ${ }^{179}$ identificó un caso para las entidades animadas que, involuntariamente, resultan afectadas por el estado, acción o proceso denotado. Se llamó caso dativo a este papel semántico. ${ }^{180}$ En mi corpus, el grupo nominal que designa al locutor secundario está en caso dativo en el $27,3 \%$ (163/596) de los encabezados oracionales en discurso indirecto no marcado que aluden a Loc 2 en el texto.

(17) a. Poe inspira a Scafati [OPI 24/01/10: 2B]

b. La fama de 'Crepúsculo' llevó a Ashley Greene a la depresión [ELP 18/01/10: 36]

c. Fuerza militar de E.U. en Haití inquieta a Francia [TРо 19/01/10: 1-6]

d. Israel compensa a la ONU por el bombardeo de su sede en Gaza [ELP 24/01/10: 8]

e. Casi 20 estaciones sísmicas han sido robadas a la UASD [HOY 20/01/10: 6A]

Los Loc 2 de los encabezados (17a) a (17e) son, respectivamente, el dibujante argentino Luis Scafati, la actriz estadounidense Ashley Greene, el secretario de Cooperación francés, un portavoz de Naciones Unidas y un sismólogo de la Universidad Autónoma de Santo Domingo (en los tres últimos ejemplos puede

\footnotetext{
${ }^{179}$ Ibid.

${ }^{180}$ En versiones más recientes de la gramática de casos, el término dativo casi se ha sustituido por el de experimentador (experiencer). Me ajusto a la propuesta original ya que las innovaciones posteriores no alteran las inferencias a que se llega en este trabajo.
} 
hablarse de sinécdoques generalizantes). De acuerdo con el sentido sugerido por el texto, estas personas o entidades adoptan una actitud pasiva ante una determinada situación: se ven afectadas por el estado, acción o proceso expresado por el verbo. Los constituyentes nominales que representan a los declarantes se hallan, pues, en caso dativo. El sentido del texto asigna a estos el papel de experimentadores de la situación expresada por el verbo, y el contexto, en cambio, perfila la interpretación de estas entidades como agentes del hecho de habla que da origen al acontecimiento noticioso.

\subsection{Alusión a Loc 2 en caso locativo}

Una frase nominal está en caso locativo cuando designa la entidad animada o inanimada que identifica la ubicación u orientación espacial del estado, acción o proceso denotado por el verbo. ${ }^{181}$ De los titulares con estructura oracional en discurso indirecto no marcado que aluden en el texto al locutor secundario, solamente el $0,8 \%(5 / 596)$ lo hace por medio de un sintagma nominal que desempeña este papel semántico.

(18) a. Tres de cada cuatro fallaron al intentar ingresar a la UCR [LAN 20/01/10: 6A]

b. Aumenta $20 \%$ el número de pacientes en el Centro de Integración Juvenil de Torreón [SOL 21/02/05: 3/B]

c. Construyen nueva galería en el Cecut [UNi 27/02/05: F3]

Por lo general, los sintagmas en caso locativo refieren, como en los testimonios de la serie (18), a instituciones o colectivos de los que Loc 2 forma parte, usualmente como directivo, alto funcionario o portavoz. En el caso de (18a), por ejemplo, cumple el papel de Loc 2 un vicerrector de la Universidad de Costa Rica (UCR); las declaraciones que dieron origen a los titulares (18b) y (18c),

${ }^{181}$ Fillmore 1968. 
procedentes del corpus piloto, fueron emitidas por empleados de niveles similares. En estos testimonios, el sintagma nominal en caso locativo alude al lugar de adscripción de Loc 2 y, metonímicamente, a este.

\subsubsection{Frases}

Solo seis testimonios en discurso indirecto no marcado aluden, en textos sin predicación, al locutor secundario; estos casos — todos sintagmas nominalesintegran apenas el 1\% (6/602) de los casos de reformulación analítica no marcada que ostentan alguna representación del declarante. Ya que son titulares formados por grupos nominales, todos ellos "se interpretan existencialmente": ${ }^{182}$

(19) a. Valiosa donación de UPS a víctimas de terremoto en Haití [MER 20/01/10: B13]

b. Mil toneladas diarias de alimentos PMA a Haití [HOY 23/01/10: 4A]

c. Indiferencia del gobierno ante la ruina de piñeros [LAP 21/02/05: 27]

d. Severa crisis económica de agricultores, en SLP [SOL 22/02/05: 4/B]

e. Memorias de un joven campeón [OPI 19/01/10: 1B]

El locutor secundario de (19a) es el presidente de la compañía UPS; el de (19b), la directora del Programa Mundial de Alimentos (PMA); el de (19c), el líder de los productores de piña afiliados a la Confederación Nacional Campesina de México; el de (19d), un portavoz de un grupo de campesinos mexicanos, y el de (19e), el joven luchador olímpico Henry Cejudo, campeón en los Juegos Olímpicos de Pekín. La escasez de testimonios impide emitir inferencias significativas; sin embargo, con relación a estos pocos casos, es posible destacar la representación de Loc 2 por medio de sinécdoques generalizantes (frecuente también, como hemos dicho, en los titulares en discurso indirecto no marcado que aluden a Loc 2 en estructuras oracionales).

${ }^{182}$ RAE y AALE 2009: $\$ 38.13 f$. 


\subsubsection{Declarante no representado en el texto, pero sí en el contexto}

En 1358 testimonios, la identidad del locutor secundario no es mencionada ni aludida metonímicamente en el titular, sino en el contexto lingüístico. Estos casos integran la variedad mayoritaria del discurso indirecto no marcado: representa el 66,5\% (1358/2041). De hecho, se trata de la variedad más abundante del discurso ajeno en los titulares periodísticos: ${ }^{183}$ el $36,8 \%$ (1358/3689) de todos los encabezados de mi corpus se halla en este caso.

(20) a. Zelaya decidirá el 27 si se va o no del país [ELN 18/01/10: A10]

b. Redrado no podrá entrar de nuevo al Banco Central [MER 24/01/10: A9]

c. David Beckham no está tan bien dotado [UNI 22/01/10: K17]

Los Loc 2 de los titulares (20a) a (20c) son, respectivamente, un asesor legal de Manuel Zelaya, el jefe de Gabinete de Argentina y una presentadora de televisión italiana. Puede advertirse que los titulares no los aluden de manera patente en cuanto tales; es en el contexto, como he dicho, donde se encuentra esta información. Reproduzco aquí un fragmento para ilustrar el caso (20a):

(20a) Zelaya decidirá el 27 si se va o no del país [ELN 18/01/10: A10]

El derrocado presidente Manuel Zelaya decidirá el 27 de enero, cuando Porfirio Lobo asuma el poder, si pide asilo o se queda en Honduras, informó uno de sus colaboradores.

"Anunciará su decisión con la convicción de que hasta ese día es el presidente del país", dijo Rasel Tomé a Radio Globo.

Tomé, asesor legal de Zelaya, afirmó: "Él no claudicará en defender sus derechos y los del pueblo hondureño". [ELN 18/01/10: A10]

\footnotetext{
${ }^{183}$ Por consiguiente, también lo es en la categoría general del discurso indirecto: representa el $60,2 \%(1358 / 2256)$.
} 
El 87,2\% (1184/1358) de estos titulares está representado por oraciones, y el 12,8\% (174/1358) restante, por frases. Estas proporciones -así como las relativas a los encabezados donde sí se representa al declarante- se explican gracias a la ya observada tendencia a formular titulares como oraciones, ${ }^{184}$ es decir, en unidades de predicación. ${ }^{185}$ De acuerdo con Garst y Bernstein, ${ }^{186}$ no es sino la tendencia propia del periodismo moderno, surgida hacia finales del siglo XIX en Estados Unidos.

\subsubsection{Oraciones}

Puesto que esta variedad del discurso indirecto no marcado carece de alusiones patentes a Loc 2 en el titular, su descripción requiere un tratamiento epistemológico ad hoc y, por consiguiente, la aplicación de métodos distintos de los empleados para caracterizar los encabezamientos que sí contienen alguna representación de Loc 2. Los conceptos de la gramática de casos, por ejemplo, solo pueden emplearse aquí en lo concerniente al contenido que, conforme a la interpretación de Loc 1, sugiere el enunciado originario: está claro que, si no se menciona en la representación verbal, el declarante no puede desempeñar papel semántico alguno en el texto.

En los titulares en discurso indirecto no marcado, la ausencia de menciones a Loc 2 como entidad implicada en el contenido representado encuentra su motivación en, por lo menos, a alguna de estas razones: que el declarante no participe en la situación originalmente representada, es decir, que el contenido del enunciado secundario aluda a terceros, o bien que Loc 1 evite nombrar o evocar al locutor

\footnotetext{
${ }^{184}$ Romero Álvarez 1990, Guízar 2004.

${ }^{185}$ Entre muchos otros, Lope Blanch 1979 y 1983, RAE y AALE 2009: §1.13a y 2010a: §1.7.1a.

${ }^{186}$ Garst y Bernstein 1940: 91-96.
} 
secundario. Ya que la primera solo depende de procesos de valoración noticiosa, dedicaré casi toda mi atención a la segunda, en particular con relación a los mecanismos gramaticales empleados con ese fin.

Sabemos que las elecciones de estructuras gramaticales responden a motivaciones ideológicas: ${ }^{187}$ como bien ha dicho Van Dijk, "las ideologías subyacentes [...] afectan las estructuras formales del lenguaje". ${ }^{188}$ En concordancia con ello, debe entenderse que, en toda forma de codificación lingüística, el locutor orienta el sentido de su enunciado hacia determinadas interpretaciones. ${ }^{189}$

Cualquier omisión voluntaria guarda relaciones muy estrechas con la postura ideológica del locutor, ${ }^{190} \mathrm{y}$, por consiguiente, con las conclusiones a las que este inclina su discurso. Para caracterizar los titulares de estructura oracional en discurso indirecto no marcado y sin alusiones patentes a Loc 2, me basaré en la oposición que establece la presencia o ausencia de sujeto léxico, entendido como el "miembro nominal del que otro mimbro predica algo". ${ }^{191}$ En ambas categorías registro el empleo de estructuras gramaticales que prescinden de toda mención del locutor secundario o del agente del proceso representado.

\footnotetext{
${ }^{187}$ Fowler 1986, Hodge y Kress 1993, Fairclough 1995b, Van Dijk 2003, entre otros; $c f$. Pêcheux (1975) 1982.

${ }^{188}$ Van Dijk 2003: 68-69.

${ }^{189}$ Ducrot (1972) 1982, 1980, (1984) 1986, Anscombre y Ducrot 1983, entre muchos otros.

${ }^{190}$ Van Dijk 2003: 60-61.

${ }^{191}$ Lope Blanch 1979: 96. Utilizo el término sujeto léxico —retomado de Alarcos (1999: \$131.1. ${ }^{\circ}$ ) - para apelar al sintagma nominal que, de manera expresa, representa el elemento [S] en la fórmula $[\mathrm{S} \leftarrow \mathrm{P}]$, que simboliza la tradicional concepción bimembrista de la oración. Mi intención es distinguir este tipo de sujetos de aquellos que, con un estatuto igualmente gramatical, no están representados de manera explícita por una frase sustantiva, como ocurre en las oraciones formadas en torno de verbos unipersonales o con sujetos tácitos. Debo aclarar que Lope Blanch no emplea este apelativo.
} 


\subsection{Oraciones con sujeto léxico}

Los titulares con sujeto léxico integran el 78,4\% (928/1184) de todos los encabezados de configuración oracional que no presentan alusiones patentes a Loc 2, pero cuyo contexto lingüístico sí. A causa de la naturaleza morfosintáctica del sujeto gramatical, esta cifra engloba los casos de entidades humanas y no humanas que concuerdan con el verbo. La oposición que dicho semema establece resulta necesaria para identificar las omisiones de Loc 2 que, por medio de recursos gramaticales, efectúa Loc 1 .

\subsection{Sujeto humano}

Presentan el sema categorial [+humano] los sujetos de 290 titulares, correspondientes al 24,5\% (290/1184) de los encabezados oracionales en discurso indirecto no marcado que solo ostentan alusiones contextuales explícitas al locutor secundario. He aquí algunos ejemplos:

(21) a. Un hombre mata a ocho personas en Virginia [ELP 21/01/10: 3]

b. Papa reza por población de Haití [HOY 24/01/10: 8B]

c. Pablo Sandoval no regresará [ELN 19/01/10: B3]

d. En Venezuela cae otro gran capo [TPо 18/01/10: 1-5]

e. Muerde ciego a su perra guía [REF 25/02/05: 27A]

Los Loc 2 de los ejemplos (21a) a (21e) son, respectivamente, un funcionario de la policía local de Virginia (Estados Unidos), el portavoz del Vaticano, el hermano del beisbolista venezolano Pablo Sandoval, el ministro del Interior de Venezuela y un agente de la policía británica. Todos los testimonios agrupados en esta categoría constituyen reformulaciones analíticas de representaciones originales que aluden a terceros. Por tanto, Loc 2 no es más que la fuente de la información noticiosa. No son pertinentes, pues, las interpretaciones que apunten a alguna omisión deliberada de Loc 2 por parte de Loc 1; en las siguientes 
secciones me referiré a los casos, absolutamente mayoritarios, que sí admiten tales lecturas.

\subsection{Sujeto no humano}

El sintagma nominal que funciona como sujeto designa entidades no humanas en 268 casos. Esta cifra equivale al 53,9\% (638/1184) de los titulares en discurso indirecto no marcado que presentan estructuras predicativas y alusiones explícitas a Loc 2 solamente en el contexto. Se trata de la forma natural de representar, sin marcas de reproducción analítica, estados o procesos referidos a animales, objetos o fenómenos naturales:

(22) a. Sismo sacudió a Guatemala y El Salvador [TPO 19/01/10: 1-6]

b. Lluvias provocan caos en Tijuana [OPI 22/01/10: 6A]

c. Las líneas fijas de telefonía son cada vez más rentables [ELP 18/01/10: 21]

d. Metano en el Ártico subirá temperaturas [ELN 18/01/10: C3]

e. Mamíferos llegaron en balsa a Madagascar [MER 21/01/10: A9]

En numerosos titulares, sin embargo, los sujetos léxicos no humanos están asociados con procesos de omisión del locutor secundario, es decir, con mecanismos lingüísticos empleados por Loc 1 para no mencionar a Loc 2 en la reformulación analítica de un enunciado original alusivo al declarante mismo. En la mayoría de estos casos, los sintagmas nominales en función sujetiva no designan entidades no humanas prototípicas — como ocurre en la serie (22)—, sino que son el resultado de metáforas gramaticales. ${ }^{192}$

\footnotetext{
${ }^{192}$ Halliday 1994; cf. infra.
} 
Al igual que Van Dijk, ${ }^{193}$ Hodge y Kress ${ }^{194}$ consideran que es posible advertir algunos aspectos de la ideología del hablante si se atiende a la mención u omisión que este hace de los participantes que normalmente están unidos por un proceso verbal: con las omisiones, concebidas por estos últimos como mecanismos de un modelo de producción textual llamado no transaccional (non transactive model), se producen enunciados comprensivos de una sola entidad del proceso aludido, la cual no siempre coincide con el agente o el experimentador. Se trata, según Fowler, ${ }^{195}$ de procesos organizativos del mensaje que responden a pérdidas del interés informativo. Como veremos, esto acarrea distintos efectos de sentido.

Mis materiales revelan que, para evitar menciones a Loc 2, los redactores de titulares periodísticos se valen de, por lo menos, tres recursos gramaticales cuyo empleo suele estar asociado, al menos en los encabezados, con oraciones que presentan sujetos no humanos: nominalizaciones deverbales, voces pasivas y oraciones subordinadas sujetivas con infinitivo. El más abundante es el primero:

(23) a. Racionamiento eléctrico en la Gran Caracas va [ELN 23/01/10: A7]

b. Por primera vez, pago íntegro a 18,000 productores de frijol [LAP 21/02/05: 44]

c. Finaliza la identificación de víctimas del 11 de septiembre [JOR 24/02/05: 33]

d. En mayo, clausura definitiva de dos tiraderos en Nezahualcóyotl [sOL 25/02/05: 5/A,3. ${ }^{\mathrm{a}}$ ]

e. Abasto de agua aún no se reestablece tras apagón en Iztapalapa [UNI 21/01/10: A10]

Una nominalización deverbal se presenta cuando se forma un sustantivo a partir de la unión de una base verbal y un sufijo; son algunos morfemas nominalizadores de la lengua española -ción, -sión, -ión, -miento, -mento, -dor, -

\footnotetext{
${ }^{193}$ Van Dijk 2003.

${ }^{194}$ Hodge y Kress (1993: 19 y ss.

${ }^{195}$ Fowler 1986.
} 
aje, -dura, -ura. ${ }^{196}$ En atención a los objetivos de esta investigación, trataré solo aquellas formaciones sustantivas ${ }^{197}$ que suelen definirse como 'acción y efecto' y que Comrie ${ }^{198}$ denominó nombres de acción (action nominals). En los casos (23a) a (23e), encontramos, con función de núcleo del sujeto, las voces racionamiento, pago, identificación, clausura y abasto, respectivamente.

Por todos conocida es la tendencia nominalizadora del discurso periodístico: Steel, por ejemplo, apunta con razón que, en este, "el grupo nominal adquiere una relevancia y una extensión mayor que en otros estilos de lengua". ${ }^{199}$ Casado Velarde destaca, por su parte, el reiterado uso de formaciones sustantivas en la confección de encabezados: "Con gran frecuencia en los titulares se presenta de forma nominalizada el hecho que se expresa con un verbo en el cuerpo de la noticia". ${ }^{200}$ En realidad, como señala Romero Gualda, se trata sin duda alguna de "un rasgo de estilo de la lengua periodística".

Para Halliday, la nominalización es el "más poderoso recurso para crear metáforas gramaticales". ${ }^{202}$ En toda metáfora gramatical, un componente semántico se construye en la gramática de manera no prototípica. Halliday propone el término metáfora gramatical para referirse al "mismo significado" que se evoca por medio de otra clase de palabra, en donde se produce una conjunción de dos niveles de significado como resultado de una nueva elección gramatical. Así, gracias a la nominalización de acciones, los procesos, normalmente expresados con verbos, se reformulan metafóricamente como

\footnotetext{
${ }^{196}$ Miranda 1994: 137 y ss. Cf. RAE y AALE 2009: §12.11.

${ }^{197}$ Alvar y Pottier 1983: 383.

${ }^{198}$ Comrie 1976: 178.

${ }^{199}$ Steel 1971: 13; $c f$. Van Dijk (1980) 1990: 117, Hurtado 2003: 110.

${ }^{200}$ Casado Velarde 1978: 103.

${ }^{201}$ Romero Gualda 1991: 547. Cf. Rebollo Torío 2008: 167.

202 "Nominalizing is the single most powerful resource for creating grammatical metaphor" (Halliday 1994: 352).
} 
sustantivos: según Koptjevskaja-Tamm, ${ }^{203}$ las formaciones sustantivas ocupan una posición intermedia entre los verbos y los sustantivos típicos, y comparten rasgos semánticos y discursivos con ambos.

Como señala Fowler ${ }^{204}$ la nominalización deverbal es un proceso organizativo del mensaje que reduce una oración a un sustantivo. Con ello, se pierde la expresión lingüística de algunos participantes en el proceso representado —-sobre todo en el caso de verbos transitivos-, así como indicaciones de tiempo y aspecto. En una lectura aislada del contexto lingüístico, el receptor de (23a), por ejemplo, puede ignorar quién raciona; el de (23b), quién paga; el de (23c), quién finaliza; el de (23d), quién clausura; el de (23e), quién abasta o abastece. Desconoce asimismo diversos matices del desarrollo de la acción verbal.

Frecuentemente, el agente de los procesos sustantivados coincide con Loc $2 \mathrm{o}$ con alguna entidad representada por este. Es el caso de los ejemplos (23a) a (23d): los locutores secundarios $-\mathrm{y}$ agentes de las acciones nominalizadas, de modo metonímico o no- son, respectivamente, el ministro de Energía Eléctrica de Venezuela, el portavoz de la Dirección de Medicina Forense de Nueva York, la secretaria de Ecología del Estado de México y la titular de la delegación Iztapalapa de la capital de México. El sentido del enunciado varía según los casos, sobre todo en función de las connotaciones que la noticia implique: puede apuntar, por ejemplo, a un disimulo de los logros y aciertos de Loc 2, o de sus errores y fracasos. Analizaré más profundamente algunos casos concretos en las observaciones finales de este capítulo.

Las construcciones pasivas también se emplean en los titulares en discurso indirecto no marcado para eludir toda mención al locutor secundario-agente. Es

\footnotetext{
${ }^{203}$ Koptjevskaja-Tamm 1993: 6.

${ }^{204}$ Fowler 1986.
} 
bien sabido que la pasivización consiste en convertir una estructura básica transitiva en una oración que exhibe al paciente como sujeto gramatical, y que permite omitir al agente del proceso. ${ }^{205}$ Desde hace mucho tiempo, se habla de pasivas impersonales —o segundas de pasiva - para designar las estructuras de este tipo que no presentan un complemento agente. ${ }^{206}$

En los ejemplos (24a) y (24b), puede apreciarse la ausencia de las entidades agentivas. El contexto lingüístico permite saber que, en ambos casos, estas coinciden con el locutor secundario o alguna entidad por él representada: se trata, en el primer caso, de la ministra peruana de la Mujer y Desarrollo Social, y de la gobernadora del Estado mexicano de Zacatecas en el segundo. ${ }^{207}$ Como dice Fowler ${ }^{208}$, el uso de estas estructuras responde a una pérdida del interés informativo por el agente del proceso, es decir, Loc 2 o la entidad que representa. Así como en las formaciones sustantivas, los efectos semántico-pragmáticos pueden ser muy diversos.

(24) a. Tres wawa wasi serán reparados [COM 22/01/10: A8]

b. Se suspende la Conago por el accidente [SOL 25/02/05: 3/A]

c. Es necesario evaluar la seguridad en la refinería "Francisco I. Madero" [soL 25/02/05: 7/B]

El ejemplo (24c) ilustra los casos de oraciones subordinadas con infinitivo. Este es el último recurso asociado con oraciones de sujetos no humanos que ocasiona posibles omisiones de Loc 2. "En el infinitivo todo verbo puede hacerse

\footnotetext{
${ }^{205}$ RAE (1931) 1962: §275 y 1973: §3.5.2, Gili Gaya 1967: §101, Alcina y Blecua (1975) 2001: \$7.5.3, Perlmutter y Postal 1977, entre muchos otros.

${ }^{206}$ RAE (1931) 1962: §275, Gili Gaya 1967: §105.

${ }^{207}$ En los titulares, las pasivas perifrásticas son menos frecuentes que las reflejas, tendencia esta explicable por la estigmatización de que aquellas son objeto en el medio periodístico, según consta en diversos libros de estilo de las organizaciones informativas.

${ }^{208}$ Fowler 1986.
} 
impersonal", ${ }^{209}$ y por tanto omitir al agente en, por ejemplo, una oración sujetiva, especialmente, como en nuestro testimonio, si el predicado de la subordinante es nominal.

Presenta el caso (24c) un adjetivo como predicado de la oración sujetiva, ${ }^{210}$ así como un verbo copulativo elidido. ${ }^{211} \mathrm{El}$ contexto lingüístico permite saber que Loc 2 es un diputado federal, pero no si este es el agente potencial del verbo evaluar: como afirma Gili Gaya y repetía la Academia, ${ }^{212}$ los infinitivos pueden tener un sujeto indeterminado, "bien sea por su carácter general, bien por falta de interés hacia él". ${ }^{213}$ En cualquier caso, de acuerdo con Van Dijk, ${ }^{214}$ la indeterminación responde a motivos ideológicos.

\subsection{Oraciones sin sujeto léxico}

Los titulares sin sujeto léxico integran el 18,9\% (256/1358) de los encabezados en discurso indirecto no marcado con estructura oracional y que solo ostentan alusiones contextuales explícitas a Loc 2. Esta categoría alberga, por un lado, oraciones cuyo sujeto no está representado por un sintagma nominal y, por otro, oraciones sin sujeto gramatical propiamente dicho. En mis materiales registro dos tipos de estructuras con tales características: oraciones con sujeto indicado únicamente en los morfemas de persona y número, y oraciones impersonales con el verbo haber.

\footnotetext{
${ }^{209}$ Bello (1847) 1958: $§ 790$.

${ }^{210} C f$. Luna Traill 1980: 26-27.

${ }^{211} C f$. Romero Álvarez 1990: 102-103.

${ }^{212}$ RAE 1973: §3.16.4e.

${ }^{213}$ Gili Gaya 1967: 143e; $c f$. Fernández y Táboas 1999: 1728-1731.

${ }^{214}$ Van Dijk 2003.
} 


\subsection{Sujeto gramatical en la flexión del verbo}

Los morfemas de número y persona cumplen la función de sujeto gramatical en 245 casos, correspondientes al 95,7\% (245/256) de todos los titulares con estructura predicativa que, sin sujeto léxico, solo refieren contextualmente a Loc 2. Numerosos son los gramáticos que han reflexionado sobre las funciones sujetivas de estos elementos lingüísticos en español; a ellos remito al lector interesado. $^{215}$ En todo caso, debe recordarse que, en nuestra lengua, el predicado verbal "contiene en sí al sujeto, sea determinado o indeterminado, y equivale por sí solo a una oración completa". 216

Muy diversos apelativos han recibido los sujetos de este tipo: tácitos, morfológicos, desinenciales, elípticos, omitidos, no expresos, implícitos. En general, suelen usarse de manera equivalente; caben, sin embargo, dos posibilidades que conviene distinguir: que las propiedades del referente coincidan con el significado del morfema de número, o no. En el primer caso, en el que existe una verdadera correferencia, estamos ante sujetos léxicos realmente tácitos u omitidos; en el segundo, nos hallamos ante un tipo de construcción impersonal, dada su interpretación indefinida. ${ }^{217}$

A propósito de la segunda posibilidad, la Real Academia Española apuntaba: "Cuando el sujeto no se expresa ni se sobrentiende por el contexto o la situación de los interlocutores, la oración se llama impersonal. Todos los verbos, transitivos e intransitivos, pueden usarse impersonalmente en la voz activa [...]. El verbo va siempre en tercera persona del plural, aunque el que habla sepa que

\footnotetext{
${ }^{215} C f$., por ejemplo, Bello (1847) 1958: §725, Gili Gaya 1967: §13, Alcina y Blecua (1975) 2001: §7.2.0.1, Alarcos (1994) 1999: §193, M. Seco 1996: §6.1.9.

${ }^{216}$ RAE (1931) 1962: §202.

${ }^{217}$ Cf. Alcina y Blecua (1975) 2001: §7.2.0.1, Alarcos (1994) 1999: §193, Fernández y Táboas 1999: 1726, Gómez Torrego 2002: §3.1.8.
} 
el sujeto es una sola persona". ${ }^{218}$ Aunque esta solución no es tan frecuente en los titulares de la prensa española como en los de la americana, se rastrea sin dificultades en los periódicos de todo el mundo hispánico. En el Nuevo Mundo es muy usual que el agente del proceso denotado por el verbo coincida, además, con el agente de la enunciación originaria:

(25) a. Suspendieron el polémico triatlón de Puerto Madero [CLA 24/01/10: 50]

b. LLEVAN AL CINE VIDA DE KINA MALPARTIDA [OPI 21/01/10: 7C]

c. Incautan camioneta con falsos emblemas de ONU [TPO 24/01/10: 1-4]

d. Descubren en Alejandría restos de antiguo templo [LAN 20/01/10: $16 \mathrm{~A}]$

Los Loc 2-agentes de estos encabezados son: en (25a), el subsecretario de Deportes de Buenos Aires; en (25b), la cineasta peruana Sonia Goldemberg; en (25c), un agente de la policía colombiana, y, en el último ejemplo, un arqueólogo egipcio. Es obvio que, en estos casos, el uso de la construcción impersonal con verbo flexionado en tercera persona del plural no encuentra su motivación en un desconocimiento del agente, sino en razones económicas o ideológicas de diversa índole.

Naturalmente, las razones ideológicas varían según las circunstancias de enunciación. Cabe distinguir, sin embargo, dos causas habituales: considerar la mención de Loc 2 irrelevante desde el punto de vista informativo, o bien juzgarla contraria a los intereses de la organización editorial. Si aislamos el factor del origen de la información y consideramos que el valor noticioso en buena medida se asigna a las declaraciones en función de las competencias o atribuciones de los declarantes-agentes, encontramos que, en casos como (25a) y (25c), el

\footnotetext{
${ }^{218}$ RAE 1973: §3.5.6; $c f$. Fernández y Táboas 1999: 1738-1742, RAE y AALE 2009: §41.9.
} 
tratamiento informativo que reciben los locutores secundarios es, por lo menos, asimétrico.

De todos los casos de discurso indirecto no marcado oracional sin representaciones léxicas de Loc 2 en el texto, pero sí en el contexto, el 87,9\% (225/256) está representado por construcciones impersonales en tercera persona del plural. Únicamente en 20 encabezados $(7,8 \%)$, todos ellos nuevamente de prensa hispanoamericana (aunque también pueden rastrearse testimonios españoles), ${ }^{219}$ el sujeto gramatical no léxico —es decir, presente solo en la desinencia del verbo - refleja los rasgos [3. ${ }^{a}$ persona, singular]. He aquí algunos de ellos:

(26) a. Suspende viaje por choque con vice [HOY 20/01/10: 16B]

b. Apuesta a la cantera [MER 23/01/10: D2]

c. Descuartizó a su novia embarazada [UNi 23/01/10: A13]

d. Por compasión inyectó heroína a hijo en coma [TРО 23/01/10: 1-10]

Según las Academias, se obtiene una interpretación indefinida $-\mathrm{y}$ por tanto impersonal- de los sujetos de estos ejemplos por la ausencia de un antecedente y porque "los sujetos tácitos que se les supone no equivalen a pronombres personales en las lenguas sin sujetos nulos (fr. il o elle; ingl. he o she, etc.)", 220 sino a grupos nominales indefinidos equivalentes a un hombre, un asesino, etcétera. Para las Academias, en estos usos que se hacen en los titulares periodísticos del ámbito hispánico, el sujeto posee rasgos de indefinitud como los observables en alguien, cierto individuo y otras expresiones equivalentes. Esta interpretación es sin duda pertinente en casos como (26c) y (26d), cuyos respectivos Loc 2-agentes del proceso verbal son personas desconocidas; pero no es tan claro en (26a) y (26b), donde sucede lo contrario: se trata, en el primer

\footnotetext{
${ }^{219}$ Es preciso aclarar, sin embargo, que, como bien señala Romero Gualda (1991), la prensa hispanoamericana tiende más al uso de construcciones impersonales que la española.

${ }^{220}$ RAE y AALE 2009: $§ 33.4$ r.
} 
caso, de la presidenta de Argentina, y, en el segundo, del entrenador de un popular equipo chileno de fútbol. Retomemos el testimonio (26a) y las primeras líneas del texto que encabeza:

(26a) Suspende viaje por choque con vice [HOY 20/01/10: 16B]

La presidenta de Argentina, Cristina Kirchner, ahondó ayer su enfrentamiento con su vicepresidente al suspender el viaje que tenía previsto realizar a China porque, según ella, Julio Cobos "no cumple su rol". "He decidido postergar mi viaje a China", dijo Kirchner. Según explicó, la visita la obliga a estar diez días fuera del país, periodo durante el cual el poder Ejecutivo quedaría en manos de Cobos, también presidente del Senado. "Es un lapso grande, cuando quien ejerce la vicepresidencia del país no cumple el rol que le asigna la Constitución y, no solamente se convirtió en líder de la oposición, sino que directamente obstruye y se opone a medidas que son resorte de la Presidencia", sostuvo la mandataria. [HOY 20/01/10: 16B]

Los morfemas flexivos desempeñan funciones catafóricas en algunos de estos casos. Con ello, Loc 1 atiende la función apelativa del encabezado: la escasa informatividad en este tipo de referencias anticipadas suele producir en el destinatario una incertidumbre inicial que lo invita a leer la nota informativa. Es ahí, en el contexto, donde puede conocerse la identidad del sujeto, que, como en todos los casos que estamos analizando, coincide con Loc 2. Pero, de cualquier manera, no debe olvidarse - como parecen hacer las Academias- que la codificación de los titulares está parcialmente condicionada por el diseño visual del periódico y que a menudo las fotografías contiguas explicitan los referentes no definidos en los encabezados, que, precisamente por fenómenos de esta índole, han sido descritos como "series visuales paralingüísticas". 221

${ }^{221}$ Verón, 1984: 146; cf., entre otros, Martínez Albertos, 2001: 416. 


\subsection{Haber impersonal}

Acaso no hay gramática que no advierta la naturaleza impersonal de ciertas construcciones con el verbo existencial haber. ${ }^{222}$ En ellas, como se sabe, no existe sujeto gramatical: el verbo aparece normalmente seguido de una frase nominal con la que no establece relación de concordancia y que en muchos aspectos funciona como objeto directo. Se consideran oraciones porque en ellas se predica la existencia del elemento nominal. ${ }^{223}$

(27) a. Hubo 15.000 homicidios en Venezuela durante 2009 [ELN 22/01/10:

A2]

b. Hay gas y petróleo en Lote 145 [COM 19/01/10: A10]

c. En tres días hubo cinco sismos en el país [CLA 20/01/10: 30]

Mi corpus contiene únicamente once testimonios con estas características; equivalen al 4,3\% (11/256) de todos los titulares de estructura predicativa que, sin sujeto léxico, solo refieren contextualmente a Loc 2. De todas las configuraciones oracionales del discurso indirecto no marcado, es esta la única que prescinde de sujeto gramatical (precisamente por tratarse de una construcción impersonal). No registro casos de discurso indirecto no marcado que presenten concordancia de haber con el sintagma nominal que introduce. ${ }^{224}$

\footnotetext{
222 Bello (1847) 1958: §780, Cuervo (1874) 1958: §104, Gili Gaya 1967: §62, RAE 1973: \$3.5.7d, Alarcos (1994) 1999: §251, Fernández y Táboas 1999: 1754-1759, RAE y A ALE 2009: $\S \S 41.6 \mathrm{a}-41.6 \mathrm{k}$.entre otros.

${ }_{223}^{223}$ Lope Blanch 1979.

${ }^{224}$ Sí recojo casos, todos ellos publicados en el diario dominicano Hoy, en otras modalidades del discurso ajeno. Los ejemplos siguientes son, como ya hemos visto, formas marcadas de discurso indirecto:
}

Experto advierte habrán más terremotos en zona del Caribe [HOY 23/01/10: 5A]

Habrían unos 150,000 muertos [HOY26/01/10: 14B]

Resulta interesante que, de todos modos, este fenómeno se atestigua con mucha menor asiduidad en los titulares que en las notas informativas, aunque es cierto que "la proporción de los usos concordados es mayor en la lengua periodística que en otro tipo de textos" (RAE y AALE 2009: §41.6b). 


\subsubsection{Frases}

Corresponde a frases el 12,8\% (174/1358) de los titulares en discurso indirecto no marcado que no contienen representaciones explícitas de Loc 2 sino en su contexto. Estos encabezados se publicaron en todos los diarios que integran mi muestra. He aquí algunos ejemplos:

(28) a. Derrame de petróleo en Texas [LAN 24/01/10: 26A]

b. Sismo de 4,1 grados [COM 18/01/10: A17]

c. Indemnización por una muerte en una operación no autorizada [MUN 07/01/09: 18]

d. Otra mujer calcinada [LAP 22/02/05: 29]

e. El más sexy del mundo [ELN 20/01/10: A1]

f. Inmaduro, puritano y genial [ELP 24/01/10: 32]

Las propiedades analítico-temáticas del discurso indirecto encuentran en esta modalidad la forma más sintética de la reformulación no marcada que permite recuperar contextualmente la identidad de Loc 2: en todas estas frases, el locutor primario manifiesta el contenido del enunciado secundario por medio de la simple mención de un tópico o tema discursivo, que en la mayoría de los casos proyecta un concepto integrador del acontecimiento noticioso. Es decir: en estos encabezados, Loc 1 suele producir una reformulación del enunciado originario a tal punto económica que prescinde de la predicación, pero a tal punto informativa que representa, por lo general, la información esencial del contenido noticioso.

Como puede advertirse en los testimonios de la serie (28), el acontecimiento noticioso suele ser presentado como estático o concluido; a ello contribuyen en buena medida las nominalizaciones y los participios. En todos los titulares de 
este tipo, el sentido del enunciado apunta a señalar que lo representado en el texto existe, o que tiene o ha tenido lugar.

\subsubsection{Declarante no representado ni en el texto ni en el contexto}

En 81 casos, que integran el 4\% (81/2041) de los testimonios en discurso indirecto no marcado, Loc 2 no es mencionado explícitamente ni en el texto ni en el contexto. La heteroglosia discursiva es, sin embargo, denunciada en este último por medio de diversas fórmulas que aluden ambiguamente a un Loc 2 de esta manera irrecuperable: según fuentes regularmente bien informadas, de acuerdo con informantes anónimos, conforme a rumores, en medios políticos se subraya, según se informó, trascendió que, se presume que, fuentes de toda solvencia confirmaron, según diversas fuentes consultadas, fuentes oficiales, altas fuentes del Ministerio de Economía, fuentes cercanas a la Casa Real y otras secuencias del mismo tipo no son infrecuentes en los periódicos.

Como afirma Fontcuberta, para los periodistas "el terreno de las declaraciones es tanto más resbaladizo cuantos más intereses entren en juego". ${ }^{225}$ Evidentemente, en estos casos nos encontramos ante contenidos procedentes de locutores secundarios que no quieren ser conocidos o bien de informantes que, a juicio del periodista, podrían correr riesgos si su identidad fuera revelada. Denominadas "atribuciones con reservas", 226 estas formas ambiguas de aludir a Loc 2 en el artículo noticioso desaparecen cuando Loc 1 reformula la información en un titular en discurso indirecto no marcado, con lo cual borra sus cautelas epistemológicas y se apropia de las palabras ajenas.

\footnotetext{
${ }^{225}$ Fontcuberta 1993: 61.

${ }^{226} \mathrm{Ibid}$.
} 


\subsubsection{Oraciones}

De acuerdo con mis materiales, se codifica como oración el 97,5\% (79/81) de los titulares en discurso indirecto no marcado que no presentan menciones explícitas de Loc 2 ni siquiera contextualmente. Reproduzco a continuación un encabezado con estas características, acompañado por un fragmento del texto que identifica (las negrillas son mías):

(29) Rajoy propondrá reducir la ESO y ampliar un año el bachillerato [ELP 18/01/10: 30]

Espoleado por las encuestas, que por primera vez le son favorables, Mariano Rajoy ha decidido aparcar su habitual ambigüedad y mojarse de lleno en un asunto clave: la educación. Tras varios meses en los que el PSOE y el PP hablan de un posible pacto educativo, el líder de la oposición presentará hoy su modelo sin esperar al acuerdo con el Gobierno, una decisión que precisamente complicará ese posible pacto. Algunos de los ejes de esta propuesta serán sin duda polémicos. El principal de ellos, según fuentes del PP conocedoras del documento que se presentará hoy en Toledo, es una propuesta de cambio radical en la secundaria.

El PP propone reducir un año la Educación Secundaria Obligatoria (ESO) y ampliar el bachillerato, de los actuales dos a tres años. [...]

El objetivo, según señalan las mismas fuentes, es doble. Por un lado, los niños que entren a los 15 años al bachillerato no tendrán en clase a los peores alumnos [...]. Y por otro, estos alumnos con más problemas tendrán la obligación de seguir estudiando [...].

Los socialistas insisten de momento en que hay que llegar a un pacto educativo que no necesariamente incluya reformas legales, como la que propondrá hoy Rajoy, sino retoques [...].

Aun así, fuentes populares señalan que en este momento las posiciones están mucho más cercanas que hace algunos años, [...] y que se puede llegar a puntos de encuentro. [ELP 18/01/10: 30]

En este caso, la omisión del Loc 2 en el contexto resulta de emplear, en estructuras de discurso indirecto marcado, los apelativos genéricos fuentes, fuentes populares y fuentes del PP. Los procedimientos, no obstante, son muy diversos, y no guardan correlación alguna con la estructura sintáctica del titular. 
He aquí otros ejemplos de encabezados que no presentan menciones específicas de Loc 2 ni en el texto ni en el contexto:

(30) a. La Policía mata en La Vega 2 hombres [HOY 18/01/10: 6A]

b. Teodoro Ribera es serio candidato a ocupar la cancillería chilena [COM 21/01/10: A7]

c. LOS FILIS CONTRATAN AL CUBANO JOSÉ CONTRERAS [OPI 23/01/10: 6C]

\subsubsection{Frases}

Solamente registro dos casos de titulares unimembres sin menciones específicas a Loc 2 en el texto o el contexto. Estos casos representan apenas el 2,5\% (2/81) de los ya relativamente poco abundantes casos en que no se alude de manera explícita a Loc 2 ni en la nota informativa ni en su encabezamiento. La escasez de testimonios responde a la evidente tendencia general a formular titulares oracionales y la preferencia por las atribuciones directas del origen de la información en los artículos noticiosos (pero no en los titulares, como ya ha quedado demostrado). Un análisis de los sucesivos corpus piloto permite rastrear casos en todos los periódicos.

(31) a. Ofensiva de FARC contra gobierno [UNI 22/02/05: A7]

b. Insólito robo a un grupo de jóvenes turistas en Villa Gesell [CLA 18/01/10: 45]

\subsection{Consideraciones finales}

He planteado hasta aquí algunas características generales que permiten identificar las variedades de discurso indirecto que presenta mi corpus. Para ello he tomado en cuenta factores muy diversos —morfológicos, sintácticos, semánticos, 
pragmáticos, modales-: recuérdese que los fenómenos de la representación textual son intrínsecamente discursivos, por lo que no deben reducirse a un solo nivel de descripción lingüística. He enfatizado en ciertas peculiaridades semántico-pragmáticas, sobre todo en lo relativo a las variedades no marcadas, con el propósito de señalar mecanismos específicos de codificación lingüística que revelen una motivación ideológica: ya ha mostrado Bajtín ${ }^{227}$ que los diferentes modelos y variedades del discurso ajeno se subordinan siempre a los propósitos de Loc 1.

El discurso indirecto ha quedado definido como la variedad del discurso ajeno que siempre presenta una reformulación analítica del enunciado originario, la cual comporta, en principio, transposiciones deícticas de persona cuando en el enunciado primario se alude explícitamente a algún participante de los cuadros figurativos de la enunciación primaria o secundaria. Esta representación de las palabras ajenas puede ser más o menos icónica ${ }^{228}$ —esto es, más o menos parecida al enunciado original-, dependiendo de si se trata de una reformulación analítico-discursiva o analítico-temática, ${ }^{229}$ es decir, de si se respetan las palabras y los giros característicos del habla de Loc 2, o si se resumen o parafrasean las palabras ajenas. En cualquier caso, el contexto producido es transparente, ${ }^{230}$ pues no hay más que un eje deíctico -el de Loc $1-$, condición esta que lo hace carecer de histrionismo. ${ }^{231}$

De acuerdo con los datos arrojados por mi corpus, el discurso indirecto presenta dos grandes variedades: una, caracterizada por la presencia explícita de algún elemento lingüístico que sugiera la existencia de una retransmisión analítica, que

\footnotetext{
${ }^{227}$ Bajtín (1935) 1986, (1963) 1986. Cf. Voloshinov (1929) 1992.

${ }^{228}$ Waugh 1995: 155.

${ }^{229}$ Voloshinov (1929) 1992: 173-174.

${ }^{230}$ Maldonado 1991: 73.

${ }^{231}$ Wierzbicka 1974: 284.
} 
he llamado discurso indirecto marcado, y otra, identificable por la ausencia de toda indicación formal en el titular, que he denominado discurso indirecto no marcado. De acuerdo con la ScaPoLine, en el primero hay siempre una "polifonía abierta", y en el segundo, una "disimulada". ${ }^{232}$

En ambos discursos, la reformulación analítica puede generar secuencias tan variadas como específicas sean las necesidades comunicativas de Loc 1: los aspectos del contiendo primitivo son susceptibles de expresarse con tantas palabras y estructuras como permita el paradigma lingüístico, o bien ocultarse de maneras tan distintas como especializadas. Es por ello que resulta imposible reconstruir con total certeza el enunciado original. Un ejemplo de la prensa mexicana:

(32) a. Revela AMLO que el PAN buscó negociar desafuero [SOL 22/02/05: 3/A]

b. Panistas propusieron a López Obrador culpar de desacato a Ortiz Pinchetti [JOR 22/02/05: 5]

Un reportero le preguntó [a Andrés Manuel López Obrador, AMLO]: “¿Es cierto que a usted o a su defensa se le habría propuesto negociar el desafuero a cambio de responsabilizar a Ortiz Pinchetti, y que incluso el vicecoordinador de la fracción del PAN [Partido Acción Nacional] en la Cámara de Diputados, Germán Martínez, habría reconocido que si lo desaforaran enfrentarían un grave problema los propios panistas?"

López Obrador dijo: "Ah, sí, ya; es cierto y dijimos no. Ya". [JOR 22/02/05: 5]

Los titulares de la serie (32) aluden a la misma declaración del jefe de Gobierno del Distrito Federal de México. En el fragmento de la nota informativa, puede advertirse que, en realidad, Loc 2 no articuló una sola de las palabras contenidas en los encabezados: solo respondió afirmativamente a una larga pregunta. La secuencia exacta que pronunció Loc 2 difícilmente coincidirá, por tanto, con las

${ }^{232}$ Nølke, Fløttum y Norén 2004: 64. 
reconstrucciones que imaginemos a partir de las reformulaciones expresadas por Loc 1, como suelen afirmar no pocos gramáticos con orientación generativista. Si bien puede hablarse de una correferencia anafórica en la situación enunciativa original, que da pauta a las reformulaciones de (32a) y (32b), parece imposible, por ejemplo, deducir el verbo proponer a partir del verbo buscar, en el caso (32a), o responsabilizar a partir de culpar, en (32b). En definitiva, como afirma Waugh, ${ }^{233}$ el discurso indirecto es mucho más complejo que lo descrito en las gramáticas, situación que el discurso de los titulares comprueba fehacientemente.

En este capítulo, he propuesto una categorización de los titulares en discurso indirecto con especial énfasis en lo que me parece el origen del problema: la mediación de Loc 1 al reformular, condensar o explicar las palabras ajenas. Es evidente que un texto en discurso indirecto no es simplemente el resultado de operaciones automáticas de transformación deíctica, sino el producto de un complejo proceso de interpretación y codificación en el que inciden, de manera decisiva, factores como la ideología subyacente y la intención perlocucionaria del acto de habla.

La marca más frecuente de reformulación analítica es una oración subordinante acompañada casi siempre por la conjunción que. En estos casos, S1 suele expresar la lectura que Loc 1 hace del acto ilocucionario original, y $\mathrm{S} 2$, la que se hace del contenido del enunciado originario. Son los verbos de habla, como ya hemos dicho, los que manifiestan buena parte de la siempre subjetiva interpretación del acto de habla: ${ }^{234}$ en (32a), por ejemplo, el acto ilocucionario se muestra como una revelación $y$, consecuentemente, se presupone que el contenido de S2 es verdadero y, además, que se mantenía en secreto.

\footnotetext{
${ }^{233}$ Waugh 1995: 157.

${ }^{234}$ Cf. Kerbrat-Orecchioni 1980, Lichfield 2000, Vicente Mateu 2007.
} 
(33) Recuerdan al obispo de Toluca que el púlpito no es para hacer política [LAP 22/02/05: 36]

En el titular (33) también se presupone el valor de verdad de S2. El semantismo de base del verbo subordinante añade otro presupuesto: el que apunta a un conocimiento previo del contenido de S2 y su valor de verdad. De acuerdo con el modelo propuesto por Ducrot, ${ }^{235}$ el sentido de este enunciado (E) puede analizarse, pues, de la siguiente manera:

E: Recuerdan al obispo de Toluca que el púlpito no es para hacer política. P1: El hecho de que el púlpito no sea para hacer política es cierto.

P2: El obispo de Toluca ya sabía que el púlpito no es para hacer política.

La existencia de los presupuestos P1 y P2 es factible de comprobarse por medio de la ley de encadenamientos: ${ }^{236}$ si coordinamos el enunciado Recuerdan al obispo de Toluca que el púlpito no es para hacer política con la secuencia Por tanto, le dijeron la verdad, se revela la presencia de P1, y si lo encadenamos con un enunciado del tipo Sin embargo, ya lo sabía, se evidencia P2. También puede recurrirse a las pruebas de la negación y la interrogación: los contenidos P1 y P2 se mantienen intactos en secuencias como Al obispo de Toluca no le recuerdan que el púlpito no es para hacer política y ¿Qué le recuerdan al obispo de Toluca?

Al introducir de manera velada el contenido P1, que podría considerarse discutible, el loc 1 transmite su postura ideológica ${ }^{237}$ : exhibe el éthos —es decir, la imagen que construye sobre sí mismo en su discurso- de alguien con pretensiones de laicidad, opuesto a la manifestación política de clérigos en sermones supuestamente religiosos. Esto explica también la presencia de P2,

\footnotetext{
${ }^{235}$ Ducrot (1972) 1982

${ }^{236}$ Ibid.

${ }^{237} C f$. Puig 2005.
} 
pues con ello se muestra al obispo de Toluca como negligente o de escasa inteligencia, es decir, como alguien que precisa recordatorios de lo que ya sabe. El efecto de sentido extiende su alcance con la introducción del contenido P1 como una verdad incuestionable.

En S1 se omite, además, la mención de Loc 2: una construcción impersonal con verbo en tercera persona del plural oculta a un importante consejero electoral. Ello parece obedecer a la nada infrecuente intención de restar importancia a Loc $2,{ }^{238}$ esto es, la fuente original del contenido expresado en S2: evidentemente, la finalidad del encabezado no es informar que el consejero electoral dijo algo, sino que el obispo de Toluca fue censurado en una situación que Loc 1 presenta como bochornosa.

Es en la relación hipotáctica donde, en este caso, se articula el juego de presupuestos que compromete a Loc 1 con el contenido del enunciado secundario. Debo advertir, sin embargo, que el discurso indirecto marcado con verbo de habla y conjunción subordinante se asocia, en muchos otros casos, con un distanciamiento de Loc 1 con respecto al contenido del enunciado de Loc 2: en principio, cuanto más neutro es el verbo de habla, ${ }^{239}$ más se presta el contexto a dicha interpretación.

(34) Científicos japoneses dicen que han creado un ratón que trina [PUB 22/12/10: 25]

En este ejemplo, Loc 1 atribuye a Loc 2, mediante una estructura de discurso indirecto marcada con el más neutro de los verbos de habla, un contenido proposicional que apunta a la creación de un ratón con habilidades de ave. Como responsable último de su acto comunicativo, Loc 1 expresa prevención o cautela

\footnotetext{
${ }^{238} C f$. Van Dijk 2003.

${ }^{239} C f$. Kerbrat-Orecchioni 1980.
} 
epistemológica ante un contenido que se antoja incierto por conocimiento enciclopédico. Gracias a la presencia de S1, Loc 1 transfiere a Loc 2 la responsabilidad asociada con el valor de verdad de S2. La inclusión de valores modales epistémicos crea, de acuerdo con Van Dijk, "la ilusión retórica de fidelidad". ${ }^{240}$ Merece la pena recordar, por cierto, que el adverbio o adjetivo dizque (< dice que), hoy usado para expresar duda o ironía en Hispanoamérica, conserva, en buena medida, el valor evidencial de la construcción que le dio origen.

Los casos de la serie (35) carecen de verbos de habla explícitos: no describen, por tanto, el acto verbal referido. Sin embargo, sus marcas de incorporación enunciativa encaminan el sentido del texto hacia la opinión que Loc 1 tiene con respecto al contenido del enunciado original:

(35) a. El paro no llegará a cuatro millones, según Corbacho [ELP 11/01/09: 22]

b. Que E. Salinas no fue asesinado en Huixquilucan [LAP 22/02/05: 10]

En (35a) y (35b), también formas marcadas del discurso indirecto, se aprecia asimismo un claro distanciamiento de Loc 1 hacia el contenido de S2: se debe, en ambos casos, a oraciones subordinantes con verbo elidido y conjunción expresa, de acuerdo con la postura aquí asumida. De acuerdo con Palmer, ${ }^{241}$ este tipo de marca añade, como todas, un relieve modal citativo: señala un origen de la información distinto de Loc 1 y, secundariamente, la falta de compromiso de este con respecto al valor de verdad que se atribuye al enunciado originario.

Así, en (35a), la conjunción según disminuye cualquier tipo de adhesión de Loc 1 con respecto al contenido de la oración subordinada: en este caso, "implica que

\footnotetext{
${ }^{240}$ Van Dijk (1980) 1990: 130.

${ }^{241}$ Palmer 1986.
} 
se deja la responsabilidad de la afirmación en cuestión a la persona o cosa expresadas por la palabra a que afecta 'según', y hasta cierta duda o disconformidad por parte del que habla". ${ }^{242}$ En otros términos, la palabra según atribuye el contenido de la reformulación a Loc 2 y, al mismo tiempo, elimina el compromiso de Loc 1 con el contenido proposicional. En consecuencia, el sentido del titular encamina al lector a concluir que la predicción que hace Corbacho puede no ser la más acertada.

Pasemos a (35b). A fin describir adecuadamente el sentido de este enunciado y otros, conviene introducir algunas nociones básicas de la teoría de la polifonía, de Ducrot: ${ }^{243}$ para este autor, los enunciados traslucen escenas virtuales de diálogo que pueden contener una serie de puntos de vista que el locutor, responsable último del enunciado, presenta y organiza según fines persuasivos específicos. Estos puntos de vista son presentados por ciertas entidades discursivas que Ducrot llama arbitrariamente enunciadores: "No se trata de personajes propiamente dichos, sino de "voces' que exhibe el enunciado", ${ }^{244}$ las cuales "se expresan a través de la enunciación, sin que por ello se les atribuyan palabras precisas". ${ }^{245}$ La posición del locutor se manifiesta por la adhesión o el distanciamiento que, según el sentido del enunciado, este establece con los puntos de vista.

Ahora bien, con la omisión del verbo de habla y del locutor secundario, Loc 1 sugiere en (35b) el procesamiento habitual de declaraciones muy similares procedentes de la misma fuente. El contenido de estas es equiparable con los dos primeros puntos de vista (pdv) que expongo en el siguiente análisis polifónico argumentativo del titular:

\footnotetext{
${ }^{242}$ Moliner 1975: s. v. según.

${ }^{243}$ Ducrot (1984) 1986.

${ }^{244}$ Puig 2000: 55.

${ }^{245}$ Ducrot (1984) 1986: 209.
} 
-Pdv1: [X] CIERTo ('Enrique Salinas fue asesinado en Huxquilucan')

-Pdv2: [E1] INJUSTIFICADO (pdv1)

-Pdv3: [E3] INCIERTO (pdv2)

El pdv1 juzga como cierto el contenido proposicional 'Enrique Salinas fue asesinado en Huixquilucan'. El pdv2 presenta como injustificado el pdv1: podríamos decir que este pdv está orientado a concluir que Enrique Salinas no fue asesinado en Huixquilucan. El pdv3, por último, asigna propiedades inciertas al pdv2: Enrique Salinas tal vez no fue asesinado en Huixquilucan. Puesto que, evidentemente, Loc 1 se identifica con el enunciador E3, el encabezado presenta a Loc 2 identificado con E1 (es decir, Loc 2 asume el pdv2), y Loc 1 informa de la existencia del pdv2, pero sin identificarse con este, sino con pdv3.

En efecto, como advierte la ScaPoLine, la sola presencia de la conjunción que suspende el valor asertivo del enunciado; ${ }^{246}$ en este caso, además, señala una actitud incrédula — de incertidumbre - por parte de Loc 1, la cual alcanza no solo al contenido de la oración subordinada, sino también a un Loc 2 que no merece siquiera ser mencionado. De acuerdo con la información contextual, el locutor secundario no es sino el director general de la policía estatal y, por consiguiente, una persona conocida en la comunidad donde se edita el periódico.

(36) Para el Gobierno, Pesce es ahora el jefe del BCRA [CLA 23/01/10: 6]

En (36) se observa también un distanciamiento de Loc 1 con respecto al contenido de S2. La preposición para como marca de discurso indirecto, al igual que la conjunción según, exige la mención de Loc 2 en $\mathrm{S} 1$, ya sea de manera concreta, indefinida o por medio de sinécdoques, muy habituales, como hemos visto, en el discurso de los titulares periodísticos. En las pocas descripciones que

${ }^{246} C f$. Nølke, Fløttum y Norén 2004: 69 
se han hecho de este uso, se insiste en que la preposición seguida de un sintagma nominal que alude a una persona introduce opiniones ajenas, pareceres cuestionables expresados por esa persona. Por ello suele decirse que dicha preposición es equivalente en estos casos a locuciones como a juicio de o en opinión de ${ }^{247}$ La asignación del carácter cuestionable al juicio representado por S2 es atribuible solamente a Loc 1, quien normalmente suscribe el pdv de un enunciador que apunta al cuestionamiento o incluso la negación del contenido de S2. De esta manera, en el caso del ejemplo (36), el contenido 'Pesce es ahora el jefe del Banco Central de la República Argentina' es representado por Loc 1 como una opinión cuestionable emitida por Loc 2 (esto es, Loc 1 suscribe el pdv de un enunciador que duda del valor de verdad de ese contenido y se presenta, aunque de manera hasta cierto punto velada, una discordancia entre Loc 1 y Loc 2).

Antes de pasar a las formas no marcadas, resulta interesante saber que el valor de modificadores de la modalidad epistémica que poseen las marcas de discurso indirecto es utilizada por los periodistas aunque no se procese un discurso ajeno. Álex Grijelmo, quien fue uno de los redactores principales del libro de estilo del diario madrileño El País y presidente de la agencia de noticias española Efe, ha puesto de manifiesto los laxos límites que, con fines de expresar cautela epistemológica, suele asignarse al discurso ajeno en la práctica periodística. Dice lo siguiente al hablar del papel del editor al corregir crónicas periodísticas, un género que supone la presencia del redactor en la situación descrita:

A veces nos encontraremos una crónica en la que se han deslizado opiniones y que nosotros debemos editar. Nos toparemos con ideas interesantes que nos gustaría mantener, pero se han expresado de tal forma que nosotros, editores exigentes de un periódico serio, no podemos tolerar. ¿Cómo rebajarlas? Hay dos trucos infalibles.

${ }^{247}$ Por ejemplo, Seco, Andrés y Ramos 1999: s. v. para, $\$ 13$. 
El primero consiste en atribuir a otros lo que el torpe cronista haya expresado como opinión propia. Es decir, emplear frases de este tipo: "según los observadores", o "según algunos asistentes", según algunas fuentes" [...] En último término, las expresiones "según los observadores" o "según algunos asistentes" siempre pueden aplicarse al observador que escribe la crónica [...]. No se trata de fórmulas aconsejables, sino de trucos para salir del paso. Un mal menor. [El otro "truco" consiste en atenuar la aserción por medio de modalizadores adverbiales] $]^{248}$

Con cualquier indicación explícita que sugiera una reformulación analítica del enunciado ajeno, Loc 1 se presenta como un intermediario que asume abiertamente la responsabilidad de la analogía entre el discurso original y su representación. Loc 1 se compromete, pues, con la fidelidad del contenido de su enunciado, pero no necesariamente con el valor de verdad. Si bien lo más frecuente es el distanciamiento con respecto al valor de verdad del contenido, testimonios como (33) comprueban que también puede haber un compromiso, situación cuya existencia suele negarse en la bibliografía especializada, donde no es infrecuente la defensa de modelos simplistas basados en la intuición de un solo hablante.

Hemos visto que el discurso de los titulares registra una tendencia hacia el aligeramiento de la retransmisión indirecta: las formas no marcadas son mucho más usuales que las marcadas; además, no parece fortuita la existencia de marcas tan sutiles como el morfema -ría o la hipotaxis con verbo elíptico. Nada de esto resulta extraño si recordamos que la codificación lingüística de los titulares periodísticos es el resultado de un complejo proceso en el que incide, de manera definitiva, la tensión que se establece entre las máximas de calidad y manera, por un lado, y la inherente a la máxima de cantidad, por otro. ${ }^{249}$ En muchos casos, no

\footnotetext{
${ }^{248}$ Grijelmo 2003: 101.

${ }^{249}$ En suma: 1) transmitir información verídica y comprobable (calidad); 2) evitar usos lingüísticos oscuros o ambiguos (manera); 3) comunicar solo la información necesaria (cantidad) (Grice 1975: 47).
} 
obstante, la falta de marcas responde también a otros factores, que veremos a continuación.

Ya decía Rodrigo Alsina que, en la etapa final del proceso de construcción de la noticia, "no todas las fuentes utilizadas son mencionadas". ${ }^{250} \mathrm{Y}$ es que, de acuerdo con las recomendaciones que hace Mencher ${ }^{251}$ a los periodistas neófitos, la atribución de las informaciones a sus respectivas fuentes debe realizarse solamente en determinados casos, como cuando el redactor no está seguro de la exactitud de los contenidos (tal como acabamos de ver). Sin embargo, el hecho de que sea "bastante frecuente que el periódico oculte la enunciación referida y apunte [...] a una enunciación directa", ${ }^{252}$ en ocasiones parece responder, al menos en lo que a nuestro objeto de estudio concierne, a cuestiones ideológicas y actitudinales de Loc 1 con respecto a Loc 2, al contenido del enunciado ajeno y, en ocasiones, incluso a todo el acto ajeno de enunciación.

(37) a. Inseguridad agrava crisis en Haití [TPO 18/01/10: 1-2]

b. Piñera mantendrá la política exterior [ELN 19/01/10: A10]

Si se considera (37a) aisladamente de su contexto, el titular no puede interpretarse sino como el resultado de una constatación del periodista. Empero, el origen de la información no es este, sino un locutor secundario: se trata del secretario general de la ONU. Es por ello que este ejemplo representa un caso de discurso indirecto no marcado.

Reyes apunta que, en casos como este, Loc 1 no hace realmente una aserción: en su opinión, solo "expresa el punto de vista de otra persona". ${ }^{253}$ Desde mi perspectiva, el expresar un punto de vista ajeno no parece constituir, per se, un

\footnotetext{
${ }^{250}$ Rodrigo Alsina 1989: 119.

${ }^{251}$ Mencher 1977: 29.

${ }^{252}$ Méndez García de Paredes 2000a: 2082.

${ }^{253}$ Reyes 1994b: 17.
} 
acto ilocucionario, y mucho menos uno que excluya al asertivo. Ciertamente, Loc 1 expresa el punto de vista de Loc 2 (o por él suscrito), pero lo hace también en forma de aserción. En conformidad con ello, parece más acertado decir que Loc 1 asevera el contenido de una aserción ajena. Ello supone, en principio, cierto compromiso de Loc 1 con el valor de verdad del enunciado.

Si las formas no marcadas de retransmisión analítica suponen una mayor confianza de Loc 1 hacia Loc 2 que las marcadas, se produce una proyección discursiva de este último como fuente informativa importante. Bien advierten Cronkhite y Liska ${ }^{254}$ que los periodistas asignan distintos grados de credibilidad a sus fuentes de información. De acuerdo con Van Dijk, en el proceso de producción del discurso noticioso "hay una jerarquía de fuentes y grados relacionados con su finalidad", y "la jerarquía social parece reproducirse en la jerarquía retórica de la credibilidad y la fiabilidad". ${ }^{255}$ Las llamadas "fuentes de élite", como políticos o funcionarios de alto nivel, se consideran, pues, más fiables como observadores o emisores de opiniones. Incluso, sostiene Van Dijk, dentro de la dinámica retórica del discurso periodístico "son más fiables que las descripciones del suceso por parte de los reporteros". 256 A tal punto es así que Loc 1 suscribe constantemente los puntos de vista de estas fuentes en la parte más privilegiada del texto informativo: el titular.

Así pues, las rutinas informativas y los procesos de producción de la noticia - que claramente tienden a favorecer la presencia de cierto tipo de voces en los medios, a las que además se les confiere gran fiabilidad- parecen motivar, al menos de manera parcial, la enorme frecuencia de uso del discurso indirecto no marcado que se observa en los titulares periodísticos de todos los diarios. Es

\footnotetext{
${ }^{254}$ Cronkhite y Liska 1980.

${ }^{255}$ Van Dijk (1980) 1990: 129-130.

${ }^{256}$ Ibid.: 130.
} 
notorio que presidentes y otros altos funcionarios son presentados con gran profusión como Loc 2 en caso agentivo, como sucede en (37b), donde la fuente informativa es el presidente electo de Chile. Estas alineaciones de Loc 1 con Loc 2 explican también el hecho de que sean casos de discurso indirecto no marcado casi todos los encabezados oracionales con verbo principal en futuro de indicativo - observable también en (37b)_, cuando de sobra se sabe que los acontecimientos noticiosos normalmente son sucesos pasados (aunque en los titulares se redacten habitualmente en presente).

Debo aclarar que no registro casos indiscutibles de discurso bivocal de orientación múltiple en discurso indirecto no marcado. ${ }^{257}$ Esto significa que, al menos en mis materiales, Loc 1 jamás manifiesta abiertamente una postura discordante con Loc 2 al reformular las palabras ajenas sin indicaciones de heteroglosia discursiva. Siempre hay, pues, una cierta fusión de puntos de vista: Loc 1 asume lo que dice Loc 2 como si fuera propio y lo articula con sus palabras. Por tanto, no le falta razón a Waugh cuando afirma que, en el discurso periodístico, es convencional atribuir a Loc 1 la responsabilidad de las secuencias en discurso indirecto no marcado. ${ }^{258}$

Los enunciados como los de (37) se interpretan, pues, como aserciones, ya sea que se tome en cuenta el contexto o no. La dialogicidad discursiva que se deduce de la lectura contextual con frecuencia propone, no obstante, una polisemia enunciativa que lleva a resultados varios. Veamos un ejemplo singular:

(38) AMLO enviará a VFQ su libro para que no le sigan mintiendo [LAP 26/02/05: 35]

\footnotetext{
${ }^{257} C f$. Bajtín (1963) 1986: 280-291.

258 "Conventionally, any words in indirect speech which are not accompanied by quotation marks — or other signs of distancing by the journalist - are assumed to represent the journalist's voice [...], but those words and structures may come from anywhere" (Waugh 1995: 157).
} 
El locutor secundario del titular (38) es Andrés Manuel López Obrador (AMLO), entonces jefe de Gobierno del Distrito Federal, de México (la abreviatura FVQ es el criptónimo de Vicente Fox Quesada, en aquel momento presidente de México). El enunciado ostenta la forma de una aserción, pero Loc 1 no parece comprometerse del todo con los contenidos de su texto. Esto se debe a una muy sutil indefinición de Loc 1 con respecto al contenido de la oración subordinada causativa final. He aquí una descripción del carácter polifónico de (38):

-Pdv1: [E1] CIERTo ('AMLO enviará su libro a VFQ')

-Pdv2: [E2] CIERTO ('el libro hará que ya no le mientan a VFQ')

-Pdv3: [E3] CIERTO ('le han estado mintiendo a VFQ')

Loc 1 se identifica con E1, pues expresa un juicio inferencial motivado por la correspondencia de Loc 2 con el agente del proceso. ${ }^{259}$ Dicho de otro modo, el titular orienta su lectura hacia la deducción, por parte de Loc 1, de que López Obrador efectivamente le enviará su libro a Vicente Fox. Esta interpretación modal se sustenta en la marca de futuridad que exhibe la oración subordinante.

Más problemática resulta la descripción de las lecturas que admite la oración subordinada causativa final. En efecto: Loc 2 se identifica con E2 y asume, por tanto, el pdv2; en cambio, el pdv3, que expresa un presupuesto, ${ }^{260}$ parece ser asumido no solo por Loc 2, sino también por Loc 1, aunque en realidad ignoramos hasta qué punto este ha adoptado como propio el pensamiento de Loc 2.

No tenemos, pues, la certeza de si Loc 1 comparte el punto de vista de Loc 2, es decir, pdv3, o si simplemente repite lo que ha dicho el productor empírico, sin identificarse con el contenido. En otras palabras, no puede dilucidarse por

\footnotetext{
${ }^{259}$ A partir, claro está, de la evidencia expresada por el agente del proceso en la enunciación originaria.

${ }^{260}$ Las pruebas de negación e interrogación lo confirman.
} 
completo si la reformulación de este segmento es analítico-temática o analíticodiscursiva. Además, la falta de evidencia situacional -y de información prosódica, claro está- impide descartar la posibilidad de que Loc 1 se identifique con un potencial enunciador que exprese un punto de vista opuesto a pdv3. Sin embargo, el hecho de que Loc 1 no marque una distancia con respecto a la oración subordinada es un argumento para justificar su adhesión.

En suma, el titular (38) presenta una adhesión completa de Loc 1 al punto de vista de E1, alusivo a la acción de enviar el libro a Vicente Fox; pero registra también una indefinición de Loc 1 con respecto al contenido que apunta a la acción de mentirle al presidente. En cualquier caso, el encabezado sugiere la posibilidad de que el presidente no esté enterado de los problemas políticos del país y de que el libro de López Obrador contenga la información verdadera. ${ }^{261}$

He caracterizado, ahora bien, las formas no marcadas de la retransmisión analítica según se aluda explícitamente o no al Loc 2 en el titular o en su contexto. Tres son las categorías distinguibles: que Loc 2 sea aludido en el titular, que Loc 2 no sea aludido en el titular, pero sí en el contexto, o bien que Loc 2 no sea aludido ni en el titular ni en el contexto, pero que en este último se denuncie la heteroglosia discursiva. He confirmado que, en las tres categorías, son más frecuentes las oraciones que las frases.

Aquellos encabezados oracionales que de alguna manera ostentan a Loc 2 han sido clasificados de acuerdo con el papel semántico que este desempeña en la predicación: agentivo, dativo o locativo. El más frecuente es el primero, normalmente registrado en oraciones con verbo en futuro o con valor temporal de futuro, como en (38). El juicio inferencial que denuncia este valor encuentra su sustento en el hecho de que el Loc 2 coincida con el agente del proceso verbal.

${ }^{261}$ El libro trata del posible desafuero de López Obrador. 
Si no se alude a Loc 2 en el titular, es obvio que no puede desempeñar papel semántico alguno. Es por ello que he apelado a un criterio estrictamente sintáctico: el sujeto gramatical. En una primera etapa, he clasificado todos los titulares oracionales de este tipo según presenten sujeto léxico o no, pues mi intención ha sido señalar los mecanismos mofosintácticos usados para no aludir explícitamente a Loc 2, bien entendido de que ello revela la postura ideológica de Loc $1 .^{262}$ La presencia de un sujeto léxico o no léxico determina los posibles procedimientos encaminados a la omisión de Loc 2.

Evidentemente, el sujeto léxico puede presentar rasgos humanos o no. En el primer caso, no registro mecanismos de omisión de Loc 2. En el segundo, identifico los siguientes: nominalizaciones deverbales, voces pasivas y oraciones subordinadas sujetivas con infinitivo.

(39) Por primera vez, pago íntegro a 18,000 productores de frijol [LAP 21/02/05: 44]

El sujeto del titular (39) tiene por núcleo una nominalización deverbal: pago. Puede advertirse que su empleo conduce, en este caso, a un efecto de ambigüedad que radica en la pérdida de información crucial, como el agente de la acción nominalizada y casi todos los matices verbales de tiempo, aspecto y modalidad. Su uso perfila la acción como estática: al convertir un proceso verbal en un sustantivo, es decir, al mostrar una acción como si fuera un objeto, la relación explícita entre procesos y participantes se muestra inmóvil. El empleo de esta entidad abstracta obvia, pues, casi toda la descripción del acto referido, lo

${ }^{262}$ Fowler 1986, Hodge y Kress 1993, Fairclough 1995b, Van Dijk 2003, entre otros; $c f$. Pêcheux (1975) 1982.. 
cual puede dar lugar a interpretaciones muy diversas: "El escritor presumiblemente conoce con exactitud el significado, pero quizá el lector no". 263

El agente de la acción nominalizada es el mismo que el de la enunciación original: la Secretaría de Agricultura de México. En principio, el titular excluye dicha entidad de las interpretaciones que se hagan sin tomar en cuenta el contexto, que es, como sabemos, el tipo de lectura efectuada por la mayoría de los consumidores de periódicos. ${ }^{264} \mathrm{El}$ formato asertivo del enunciado apunta a un compromiso de Loc 1 con el contenido de las palabras de Loc 2; pero la tenaz omisión de este — no solo como fuente de la información, sino también como agente de la acción aludida - evidencia una ideología subyacente encaminada a restar importancia a los posibles logros de la entidad que origina la información noticiosa. $^{265}$

Los titulares con sujeto no léxico omiten siempre la mención de Loc 2, como es obvio. Dos son los mecanismos que registro: construcciones impersonales con el verbo haber y oraciones con sujeto gramatical en la flexión del verbo. En estos casos - así como en los anteriores - la omisión de Loc 2 puede deberse a motivaciones muy diferentes: ideología de Loc 1, economía lingüística, naturaleza del hecho verbal o desconocimiento de información importante. ${ }^{266}$ En la mayoría de los casos, sin embargo, el contexto proporciona los datos que en el encabezado se evitan. ${ }^{267}$

\footnotetext{
263 "The writer presumably knows exactly what it means; but the reader may not" (Halliday 1994: 353).

${ }^{264}$ Emig 1927, Eco 1977, Casado Velarde 1984, entre otros.

${ }^{265} C f$. Van Dijk 2003.

${ }^{266} C f$. R. Seco 1954.

267 Además, en la omisión por razones económicas no deja de traslucirse una motivación ideológica, pues elegir cuál información se calla y cuál no supone una escala de valores en la política editorial. La omisión por desconocimiento supone evitar el reconocimiento de cierta ignorancia, lo cual también contribuye a la configuración del éthos, con todas las connotaciones ideológicas que ello supone.
} 
Como bien afirma Voloshinov, en cualquier forma de discurso indirecto Loc 1 elimina "todo aquello que no tiene importancia temática alguna",268. El decidir qué la tiene - y por ende qué no- es, de acuerdo con Van Dijk ${ }^{269}$, señal inequívoca de ideología subyacente. Luego entonces, el dar un tratamiento idéntico a entidades jerárquicamente diferenciadas, o uno diferente a entidades del mismo nivel, devela asimismo líneas editoriales.

Por último, el hecho de que en ocasiones no se especifique la identidad de Loc 2 ni en el titular ni en la nota informativa, da ocasión para suponer que, probablemente, existan muchos más casos de conjunciones discursivas en los titulares periodísticos: nada impide, en realidad, que Loc 1 no solo omita el nombre del locutor secundario, sino que calle toda insinuación de discurso ajeno. De hecho, Fontcuberta identifica un tipo de "atribución" utilizada a menudo por los periodistas, denominada "atribución de reserva obligada", en donde "el medio no menciona a la fuente y cuenta las informaciones como si fueran propias". ${ }^{270}$ Más aún: Rivadeneira Prada describe como habitual en los medios la práctica de lo que él denomina "refrito", es decir, "una forma disimulada de plagio" que consiste en "la reelaboración de una noticia publicada por la competencia"271 (según datos de Rodrigo Alsina, ${ }^{272}$ las fuentes más frecuentes en la prensa española son, precisamente, otros medios de comunicación). Con esto en mente, no resulta muy aventurado estimar que la proporción de discurso indirecto no marcado sea mayor que el 55,3\% (2041/3689) aquí descrito: ${ }^{273}$ como ya observaba Bajtín, ${ }^{274}$ parece que, al fin y al cabo, la lengua misma es polifónica.

\footnotetext{
${ }^{268}$ Voloshinov (1929) 1992: 173.

${ }^{269}$ Van Dijk 2003.

${ }^{270}$ Fontcuberta 1993: 61.

${ }^{271}$ Rivadeneira Prada 2007: 99. Cf. Gaillard 1972: 113.

${ }^{272}$ Rodrigo Alsina 1989: 119.

${ }^{273}$ Por poca reflexión que se haga, se concluirá que resulta imposible disponer de toda la información concerniente al contexto extralingüístico que permita identificar todos los casos de estilo indirecto no marcado sin ninguna alusión a la heteroglosia discursiva. También es imposible cuantificarlos, por ende.

${ }^{274}$ Bajtín (1935) 1986, (1963) 1986.
} 


\section{DiscuRso NARRADO}

Casi todos los estudiosos del discurso ajeno - ya sea desde la perspectiva de la gramática o de la estilística- han centrado su atención en los fenómenos de la representación discursiva, es decir, la propiedad que tienen todas las lenguas ${ }^{1}$ de reproducir, de manera más o menos icónica, las palabras ajenas. ${ }^{2}$ Se encuentran en este caso todas las investigaciones que reducen el complejo problema del discurso ajeno a las añejas clasificaciones bipartitas o tripartitas del discurso representado (discursos directo-indirecto o bien estilos directo-indirecto-indirecto libre).

Ya hemos apuntado que en la categoría denominada por Bally "estilo indirecto libre" ${ }^{23}$ a menudo se incluyen, sin distinción alguna, todas las formas no marcadas de la representación discursiva, excluidas normalmente de las sistematizaciones bipartitas. Aunque muy generalizado y más depurado que su antecesor, el modelo basado en la categorización directo-indirecto-indirecto libre no está exento de limitaciones: ${ }^{4}$ además de no distinguir normalmente entre sí las variedades carentes de marca, excluye las formas que aluden a actos de habla sin representar necesariamente el contenido de los enunciados ajenos.

Es preciso recordar que, retomando los planteamientos seminales de Voloshinov, concibo el discurso ajeno no solo como "discurso en el discurso, enunciado

\footnotetext{
${ }^{1}$ Por ejemplo, Li 1986: 39-40; $c f$. Jakobson (1936-1963) 1981: 308-309.

${ }^{2}$ Jespersen (1924) 1968, RAE (1931) 1962 y 1973, Gili Gaya 1967, Wierzbicka 1974, Alcina y Blecua (1975) 2001, Authier y Meunier 1977, Rivarola y Reisz de Rivarola 1984, Reyes 1984, 1993 y 1994a, Coulmas 1985, 1986 y 1994, Hand 1991, Maldonado 1991 y 1999, RAE y AALE 2009: $§ \$ 43.9$ y 43.10 , entre otros.

${ }^{3}$ Bally 1912.

${ }^{4}$ Cf. Maingueneau 1981: 98.
} 
dentro de otro enunciado", sino también como "discurso sobre otro discurso, enunciado acerca de otro enunciado". 5 Esto significa que no siempre supone el cumplimiento de la "condición" de representatividad, ${ }^{6}$ es decir, emplear una cadena verbal para expresar el contenido - o la forma y el contenido- de un enunciado producido por otra persona: antes bien, el discurso ajeno comprende cualquier alusión o presencia de una enunciación ajena en la propia.

Después de los estudios de Bajtín-Voloshinov y de Jakobson sobre la comunicación verbal, y de los de la lingüística de la enunciación sobre el propio discurso ajeno, no parece aconsejable mantener la tradicional postura que apunta a la reducción del objeto de estudio del discurso ajeno a la simple cita de palabras (o pensamientos). Como afirma Girón Alconchel, las formas del discurso ajeno “no reproducen sólo palabras (llámeseles 'enunciados' o 'textos'); reproducen, sobre todo, las situaciones comunicativas en que esas palabras cobran su cabal sentido. Es decir, reproducen actos de habla"?

Las formas narrativizadas del discurso ajeno presentan el acto de habla original como cualquier otro tipo de acción ${ }^{8}$ y "permiten resumir brevemente la acción comunicativa sin informar sobre el contenido proposicional del discurso citado". 9 Muy diversos son los autores que, además de reconocer la existencia de este tipo de secuencias, sugieren que se trata de formas del discurso ajeno. ${ }^{10}$ La mayoría de ellos, sin embargo, no les dedica más de unas cuantas líneas.

\footnotetext{
${ }^{5}$ Voloshinov (1929) 1992: 155. Cursivas en el original.

${ }^{6}$ Cf. Maldonado 1991: 20.

${ }^{7}$ Girón Alconchel 1989: 71. Cursivas en el original.

8 "The speech act is reported in a way that puts it on a par of other kinds of action" (Leech y Short 1981: 324).

${ }^{9}$ Fonte 1998: 34.

${ }^{10}$ Todorov (1968) 1975: 60, Genette (1972) 1989: 228 y (1993) 1998: 40, Page 1973: 35-37, Bal (1978) 1990: 141, McHale 1978: 258, Leech y Short 1981: 323, Toolan 1988: 122, Wales 1989: 314-315, Girón Alconchel 1989: 95-96, 1993: 205-208 y 2006: 404-405, Chafe 1994, Perret 1994: 101, Schaeffer (1995) 1998: 658-659, Fonte 1996c: 41-48, 1998: 34 y 1999: 145, Thompson 1996: 517-518, Collins 2001: 124-125, Sakita 2002: 190.
} 
Como es natural en la designación de un concepto nuevo, los apelativos propuestos son muy variados: "discurso narrativizado", ${ }^{11}$ "discurso narrado", ${ }^{12}$ "discurso contado", 13 "reporte narrativo del acto verbal", 14 "voz referida"," "voz narrada", ${ }^{16}$ "discurso sumergido", 17 "resumen de la historia", 18 "estilo global o interpretativo", ${ }^{19}$ "sumario diegético" ${ }^{20}$ y otros más. ${ }^{21}$ En este trabajo he adoptado el término discurso narrado por tratarse del más usual en el ámbito de la lingüística hispánica. ${ }^{22}$

(1) a. Sergio Andrade se dice inocente en audiencia [UNI 22/02/05: E1]

b. ETA habla de lucha política [ELN 18/01/10: A10]

c. Isabel II habla en la ONU por primera vez en 53 años [MER 24/01/10: A10]

En todos estos encabezados, Loc 1 alude expresamente a un acto de habla ajeno, pero sin recurrir a las estructuras de los discursos directo o indirecto marcados: el hecho de habla es "tratado como un acontecimiento [...] y asumido como tal por el propio narrador". ${ }^{23}$ Esto significa que Loc 1 refiere el acto de habla de Loc 2 por medio de estructuras textuales usadas habitualmente para narrar acciones no verbales, es decir, para componer lo que Genette $^{24}$ denomina relato de

\footnotetext{
11 "Discours narrativisé" (Genette [1972] 1989: 228, Perret 1994: 101).

${ }^{12}$ Girón Alconchel 1989: 95, 1993: 205-208 y 2006: 404-405.

${ }^{13}$ Todorov (1968) 1975: 60.

14 "Narrative report of speech act" (Leech y Short 1981: 323-324, Wales 1989: 314-315).

${ }^{15}$ Beltrán Almería 1992: 87-93.

${ }^{16}$ Fonte 1996a: 148, 1996b: 214, 1998: 34 y 2002: 31.

17 "Submerged speech" (Page 1973: 35-37).

${ }^{18}$ Bal (1978) 1990: 141.

${ }^{19}$ Núñez Ladevéze 1995: 193-194.

20 "Diegetic summary" (McHale, 1978: 258).

21 "Narrational summary speech" (Toolan 1988: 122), "refered-to speech" (Chafe 1994).

${ }^{22}$ También es usual el término "voz narrada" ( $c f$. , por ejemplo, Fonte 1996a: 148, 1996b: 214, 2002: 31).

${ }^{23}$ Genette (1972) 1989: 227.

${ }^{24}$ Ibid.: 223.
} 
acontecimientos: el discurso narrado ocupa la linde entre relato de palabras y relato de acontecimientos. ${ }^{25}$

El último grado de transformación de las palabras del personaje es aquel que puede denominarse "discurso contado": en este caso nos contentamos con registrar el contenido del acto de palabra sin retener ninguno de sus elementos. Imaginemos la siguiente frase: 'Informé a mi madre de la decisión de casarme con Albertina'; indica, por cierto, que ha habido una acción verbal y también indica el tenor de la misma; pero nada sabemos de las palabras que habrían sido 'realmente' (es decir, ficticiamente) pronunciadas. ${ }^{26}$

Con estas palabras, ya denunciaba Todorov la existencia de una forma de procesar las palabras ajenas, o de representar un acto de habla ajeno, sin retener términos del enunciado originario pero con la posibilidad de aludir al contenido. Como hemos dicho, el discurso narrado permite a Loc 1 representar hasta cierto punto las palabras de Loc 2 o bien limitarse "a indicar la existencia de un acto de habla". ${ }^{27}$ Puede advertirse que los titulares de la serie (1) presentan distintos grados de especificación del contenido expresado originalmente por Loc 2: en (1a) se representan — de manera escueta si se quiere - las palabras de Loc 2; en (1b) no se especifica más que el tema general del discurso referido, y en (1c) solo se refiere una acción realizada verbalmente. Bien sugiere $\mathrm{McHale}^{28}$ que el discurso narrado tiene la facultad de ser más o menos diegético, dependiendo de si se especifica el contenido del enunciado original o no. "Dentro del $\mathrm{D}$ [iscurso]N[arrado] hay también variantes. El verbo de comunicación puede significar simplemente un acto de habla; puede también dejar entrever, al mismo tiempo, su imaginaria textura verbal", anota Girón Alconchel. ${ }^{30}$

\footnotetext{
${ }^{25}$ Hace muchos siglos, Platón (República, III: $\S \$ 392 b-394 c$ ) ya hablaba de formas discursivas que combinan mímesis y diégesis.

${ }^{26}$ Todorov (1968) 1975: 60. Cursivas en el original.

${ }^{27}$ Girón Alconchel 1993: 205.

${ }^{28}$ McHale 1978.

${ }^{29}$ Cf. Leech y Short 1981: 323-324.

${ }^{30}$ Girón Alconchel 1993: 205.
} 
El hecho de que existan formas de discurso narrado con cierto grado de representación discursiva constituye una evidencia que refuta el argumento esgrimido por no pocos especialistas para justificar la tenaz exclusión de que esta categoría ha sido objeto en casi todos los estudios gramaticales del discurso ajeno: quienes no ignoran del todo el asunto suelen argüir que, en las formas narrativizadas, "no puede percibirse citación alguna", ${ }^{31}$ puesto que — aseguranesta se delimita por la "condición" de representatividad discursiva, definitoria para ellos del discurso ajeno. ${ }^{32}$ Denuncian las dimensiones del error casos como (1a), que ostenta prácticamente la misma representatividad discursiva que la secuencia Sergio Andrade dice en audiencia que es inocente, forma prototípica del discurso indirecto, presente sin controversias en todos los tratados sobre la materia.

La confusión parece tener su origen en la costumbre de no sustentar los estudios del discurso ajeno en corpus estrictamente recopilados: los analistas, confiados la mayoría de las veces en su intuición lingüística, no tienen en mente casos como (1a), o los omiten de manera deliberada. Autores hay —eso sí- que, a pesar de adherirse a la hipótesis de la representatividad como condición sine qua non del discurso ajeno, advierten el grave sesgo que supone. ${ }^{33}$ En cualquier caso, me parece que deben replantearse los criterios definitorios del discurso ajeno, como se ha hecho aquí, siguiendo la pauta trazada por Voloshinov ${ }^{34}$ hace ya algunos años, pues ello permite desterrar el sesgo metodológico impuesto por "el prejuicio de que citar es sólo citar palabras". 35

\footnotetext{
${ }^{31}$ Reyes 1984: 78.

${ }^{32}$ Cf. Maldonado 1991: 20, Reyes 1993: 12, por ejemplo.

33 "I am unable to suggest any coherent solution, as all the possible analyses that I can see seem to involve grave difficulties" (Wierzbicka 1974: 294).

${ }^{34}$ Voloshinov (1929) 1992: 155.

${ }^{35}$ Girón Alconchel 1989: 71.
} 
La representación discursiva no es, desde luego, el rasgo definitorio del discurso narrado: como he dicho - y ejemplificado con (1c)—, esta variedad del discurso ajeno es la única que puede referir una enunciación ajena sin representar su contenido. Para caracterizarla acudiré aquí también al principio de la correspondencia irrenunciable entre forma y significado en configuraciones gramaticales abstractas: ${ }^{36}$ el discurso narrado presenta características formales y funcionales que —al menos en los titulares periodísticos_ la distinguen claramente de las demás variedades del discurso ajeno.

A diferencia de los discursos directo e indirecto marcados, el discurso narrado no solo admite verbos de habla transitivos y prepositivos, sino también intransitivos. $\mathrm{Al}$ igual que el discurso directo marcado con verbo de comunicación verbal $-\mathrm{y}$ a diferencia del indirecto con verbo de habla explícito o elíptico- ${ }^{37}$ admite objetos directos no oracionales; a diferencia del directo $-\mathrm{y}$ al igual que el indirecto-, sus objetos directos nunca se enlazan con el núcleo del predicado por medio de signos gráficos. Aunque en baja proporción, también se estructura en frases que tienen por núcleo la nominalización de un verbo de habla.

En otras palabras, el discurso narrado se estructura en frases nominales o bien en predicados intransitivos o transitivos, y, en el caso de estos últimos, los objetos directos o prepositivos, oracionales o no, jamás están separados del resto del titular por medio de índices gráficos. Resulta interesante advertir que, en los

\footnotetext{
${ }^{36}$ Fillmore 1982, Goldberg 1995, Kay 1997, entre otros.

${ }^{37}$ Posible excepción hecha de los casos, inexistentes en mis materiales, a los que algunos atribuyen, no sin controversia, una incorporación de "fragmentos oracionales". A veces se asegura que, en secuencias como dice que sí, dice que no o dice que mañana —los cuales, precisamente por su carácter conflictivo, han sido considerados ejemplos de una variedad mixta que Spitzer (1946) llamó "discurso directo ligado"-, "la cita indirecta está constituida por 'fragmentos oracionales', entendiendo por tales aquellos enunciados que carecen de una forma verbal flexionada que los dote de independencia sintáctica y semántica (son, por tanto, enunciados gramaticalmente incompletos aunque contextualmente adecuados e interpretables)" (Maldonado 1999: 3575; $c f$. RAE y AALE 2009: §43.9p).
} 
testimonios de objeto directo oracional, el verbo subordinado es siempre un infinitivo, como se observa en los ejemplos siguientes:

(2) a. Asegura Marina tener un bajo número de quejas [UNI 22/02/05: A15]

b. Venezuela pide a EE UU abrir el diálogo sobre las bases en Colombia [ELP 23/01/10: 7]

c. Morales promete respetar la propiedad [ELN 22/01/10: A11]

d. Obispo llama al pueblo a solidarizarse con haitianos [HOY 18/01/10: 7E]

Como bien señalan las Academias, "en la actualidad se suele aceptar que los infinitivos del español pueden ser verbales o nominales". ${ }^{38}$ En el caso de los primeros, admiten argumentos propios del verbo: sujetos, objetos directos, objetos indirectos, complementos de régimen o circunstanciales. ${ }^{39}$ Por el contrario, "el infinitivo con oficio de sustantivo, amén de aceptar, en algunos casos, gramemas de número, irá acompañado de los modificadores propios de tal categoría". ${ }^{40}$ En esta investigación no adopto la postura que apunta a siempre considerar sustantivos los infinitivos de todo tipo. ${ }^{41}$ Aun asumiendo que así fuese, los resultados del presente estudio no se verían alterados de manera significativa, ya que en los titulares el discurso narrado tiende masivamente a estructuras de oración simple.

El discurso narrado tiene, desde luego, funciones específicas y especializaciones de uso. ${ }^{42}$ Ya hemos dicho que, en términos narrativos, se produce una "reducción del discurso al acontecimiento". ${ }^{43}$ Desde un punto de vista pragmático, ello encierra la única finalidad esencial de referir el acto de habla ajeno, no la de representar las palabras de Loc 2, como ocurre en todas las formas de los

\footnotetext{
${ }^{38}$ RAE y AALE 2009: $\$ 22.6 a$.

${ }^{39}$ Cf. Herranz 1999.

${ }^{40}$ Luna Traill 1980: 22.

${ }^{41}$ Cf. Alarcos (1994) 1999: §§201 y 202, Gutiérrez Ordóñez 1997: 177-179.

${ }^{42} C f$. Fonte 1996c: 42 y 1998: 35.

${ }^{43}$ Genette (1972) 1989: 228.
} 
discursos directo e indirecto: "Si el discurso directo representa forma y contenido proposicional, y el discurso indirecto contenido proposicional, las formas narradas dan cuenta del acto verbal o del evento comunicativo en forma global". ${ }^{44}$ Esto explica el hecho de que todos los casos de discurso narrado de mi corpus ostenten verbos de habla o bien derivados nominales de estos, y que, como acabamos de ver, no siempre se represente el contenido del enunciado originario.

Cuando la hay, la representación discursiva es siempre sintética. ${ }^{45}$ Este hecho parece haber confundido a algunos analistas, según los cuales el discurso narrado es una variedad del discurso indirecto. ${ }^{46} \mathrm{Si}$ bien es cierto que tanto el discurso narrado como el indirecto pueden contener reformulaciones analítico-temáticosintéticas del enunciado secundario, no debe olvidarse que el discurso indirecto se caracteriza por el requisito ineludible de expresar el contenido de las palabras ajenas. Sus inherentes propiedades icónicas imposibilitan que los casos de discurso narrado sin representación discursiva sean "simplemente" casos de discurso indirecto donde Loc 1 ha suprimido el contenido del enunciado originario. ${ }^{47}$ En realidad, el discurso narrado se encuentra en un estado de mayor

\footnotetext{
${ }^{44}$ Fonte 1998: 34.

${ }^{45}$ Leech y Short 1981: 324, Fairclough 1988: 127, Toolan 1988: 122, Waugh 1995: 160, Sakita 2002: 190, entre otros.

${ }^{46}$ Verschueren 1985, Waugh 1995, Li 1986, Sakita 2002. Aunque en su estudio sobre las formas del discurso referido en el Cantar de mio Cid Girón Alconchel asignaba al discurso narrado el estatuto de "variante sintagmática del D[iscurso]I[ndirecto]" (Girón Alconchel 1989: 95), en textos posteriores se aprecia claramente una rectificación, ya que es presentado como una modalidad distinta. En un trabajo publicado poco tiempo después, donde describe los usos de las variedades del discurso ajeno en un artículo periodístico, se lee: "Además del $\mathrm{D}$ [iscurso][[ndirecto], que reproduce el discurso en forma de resumen más o menos abstracto, y del $\mathrm{D}$ [iscurso]D[irecto], que es una reproducción textual de las palabras del personaje, aparece en el texto el discurso narrado" (Girón Alconchel 1993: 205; las cursivas son mías). Esta nueva postura se observa también en su investigación de 2006.

47 "[The utterance John told Peter something] is simply a case of indirect speech in which the reporter-speaker has suppressed the content of the reported speech" (Li 1986: 42).
} 
gramaticalización que el discurso indirecto: sus "variantes son más abstractas, menos variables, más cohesionadas y más integradas semánticamente”. 48

Más adelante veremos que la evidencia de los titulares periodísticos parece dar la razón a Leech y Short ${ }^{49}$ en el sentido de que el discurso narrado constituye una variedad del discurso ajeno más indirecta que el discurso indirecto; veremos también que, por tanto, no se equivoca Rubio Fernández cuando hace notar que "todo el campo que queda fuera del estilo directo no es uniformemente indirecto". ${ }^{50}$ Baste por ahora saber que todas las formas del discurso ajeno se distribuyen a lo largo de una gradación, muy variable según los factores que se consideren: mimesis, ${ }^{51}$ distancia narrativa, ${ }^{52}$ diferenciación de voces ${ }^{53}$ u otros.

Conviene recordar que, en este trabajo, se consideran verbos de habla todos aquellos pertenecientes al área conceptual de la realización de actos lingüísticos de cualquier índole. Todos los verbos de habla designan un acto locucionario y, frecuentemente, describen también el acto ilocucionario. Esta descripción puede resultar bien de una interpretación y constatación de Loc 1 o bien de la actualización de un acto performativo explícito originario. Sea cual fuere el caso, Loc 1 asume la responsabilidad de las especificaciones que la selección léxica concreta añada al significado referencial básico ('decir'), el cual en ocasiones se transfiere, metafórica o metonímicamente, a verbos que en principio no suponen un comportamiento verbal.

Son muy diversas las especificaciones que añaden los distintos verbos de habla: además de explicitar la fuerza ilocucionaria, indican el modo de realización

\footnotetext{
${ }^{48}$ Girón Alconchel 2006: 404.

${ }^{49}$ Leech y Short 1981: 323.

${ }^{50}$ Rubio Fernández 1976: 66.

${ }^{51}$ McHale 1978.

${ }^{52}$ Genette (1972) 1989.

${ }^{53}$ Voloshinov (1929) 1992.
} 
fónica (gritar, susurrar), sitúan la enunciación ajena en la cronología discursiva (repetir, concluir, predecir), presuponen el valor de verdad o falsedad de las palabras ajenas (revelar, mentir). ${ }^{54}$ Incluso hay verbos que contienen información implícita y significan 'decir algo': ${ }^{55}$ presentarse significa 'decir quién es uno mismo', o maldecir, 'decir maldiciones'; tal es el caso, por ejemplo, del verbo de (3a), felicitar, pues, como sabemos, significa 'expresar complacencia o buenos deseos' (en estos casos, el discurso reproducido es "un rasgo sémico del verbo"). ${ }^{56}$ Debido a su naturaleza delocutiva — pues son formas léxicas creadas a partir de valores enunciativos—, ${ }^{57}$ estos últimos verbos dificultan, en cierta medida, una caracterización rigurosa del discurso narrado en términos de la cuantificación mimética que propone McHale. ${ }^{58}$

(3) a. AmCham felicita al Gobierno [LAN 18/01/10: 12A]

b. Condolencias del Ejecutivo por la muerte del gobernador [LAP 26/02/05: 35]

El encabezado (3b) ejemplifica la capacidad que tiene el discurso narrado de codificarse en frases nominales. El sustantivo condolencias es, como se sabe, una formación sustantiva del verbo condolerse, que significa 'expresar un sentimiento de lástima por lo que otra persona siente o padece': en otras palabras, puede decirse que en el sustantivo condolencias subyace el verbo condolerse ${ }^{59}$ que, en este caso, supone un comportamiento verbal y, por tanto, es un verbo de habla. La acción, rasgo definitorio del discurso narrativo, es referida por medio de un sustantivo o, con palabras de Comrie, de un "nombre de acción" (action nominal). ${ }^{60}$

\footnotetext{
${ }^{54}$ Maingueneau 1981: 101.

${ }^{55} \mathrm{Cf}$. Maldonado 1991: 56.

${ }^{56}$ Girón Alconchel 2006: 404.

${ }^{57}$ Para una revisión del concepto de delocutividad a partir de Benveniste, $c f$. Puig 2000: 19-46.

${ }^{58}$ McHale 1978.

${ }^{59}$ Cf. Comsky 1957 y 1970.

${ }^{60}$ Comrie 1976: 178.
} 
Los testimonios de discurso narrado integran el 23,6\% (872/3689) —es decir, casi la cuarta parte - de toda la muestra. El siguiente cuadro contiene la relación exhaustiva de frecuencias relativas de uso en cada uno de los diez diarios tomados en cuenta para la descripción cuantitativa: ${ }^{61}$

\begin{tabular}{|l|l|}
\hline \multicolumn{1}{|c|}{ Diario } & $\begin{array}{c}\text { Frecuencia relativa } \\
\text { de uso }\end{array}$ \\
\hline El País (Madrid) & $24,9 \%(63 / 253)$ \\
\hline La Opinión (Los Ángeles) & $21,5 \%(32 / 149)$ \\
\hline El Universal (México) & $26,3 \%(166 / 630)$ \\
\hline La Nación (San José de Costa Rica) & $16,6 \%(50 / 301)$ \\
\hline Hoy (Santo Domingo) & $31,8 \%(169 / 531)$ \\
\hline El Tiempo (Bogotá) & $17,5 \%(50 / 286)$ \\
\hline El Nacional (Caracas) & $23,7 \%(88 / 372)$ \\
\hline El Comercio (Lima) & $19,5 \%(78 / 400)$ \\
\hline El Mercurio (Santiago de Chile) & $23,6 \%(103 / 436)$ \\
\hline Clarín (Buenos Aires) & $22,1 \%(73 / 331)$ \\
\hline
\end{tabular}

Puede advertirse que casi todos los periódicos codifica como discurso narrado entre el 20 y el $25 \%$ de sus titulares. Se alejan de ello, por un lado, el costarricense La Nación y el colombiano El Tiempo, que registran frecuencias relativas de uso menores, y, por otro, el mexicano El Universal y el dominicano Hoy, que presentan incidencias mayores. En particular destaca este último, cuya preferencia por titulares en discurso narrado casi duplica las de La Nación y El

\footnotetext{
${ }^{61}$ Por diarios, la distribución global del discurso narrado es la siguiente: El País, 7,2\% (63/872); La Opinión, 3,7\% (32/872); El Universal, 19\% (166/872); La Nación, 5,7\% (50/872); Hoy, 19,4\% (169/872); El Tiempo, 5,7\% (50/872); El Nacional, 10,1\% (88/872); El Comercio, 9\% (78/872); El Mercurio, 11,8\% (103/872); Clarín, 8,4\% (73/872).
} 
Tiempo (es decir, llega casi a la tercera parte). El Universal, en cambio, excede en poco el $25 \%$, en un rango más bien similar al del español El País, aunque es verdad que este último diario no se aparta significativamente de la media, representada por el chileno El Mercurio y el venezolano El Nacional. Lo mismo puede decirse del argentino Clarín y el estadounidense La Opinión. El rotativo peruano El Comercio, por su parte, se sitúa en un rango muy cercano al de $E l$ Tiempo. En ningún periódico, la frecuencia relativa de uso del discurso narrado es inferior al $15 \%$ ni superior al $35 \%$.

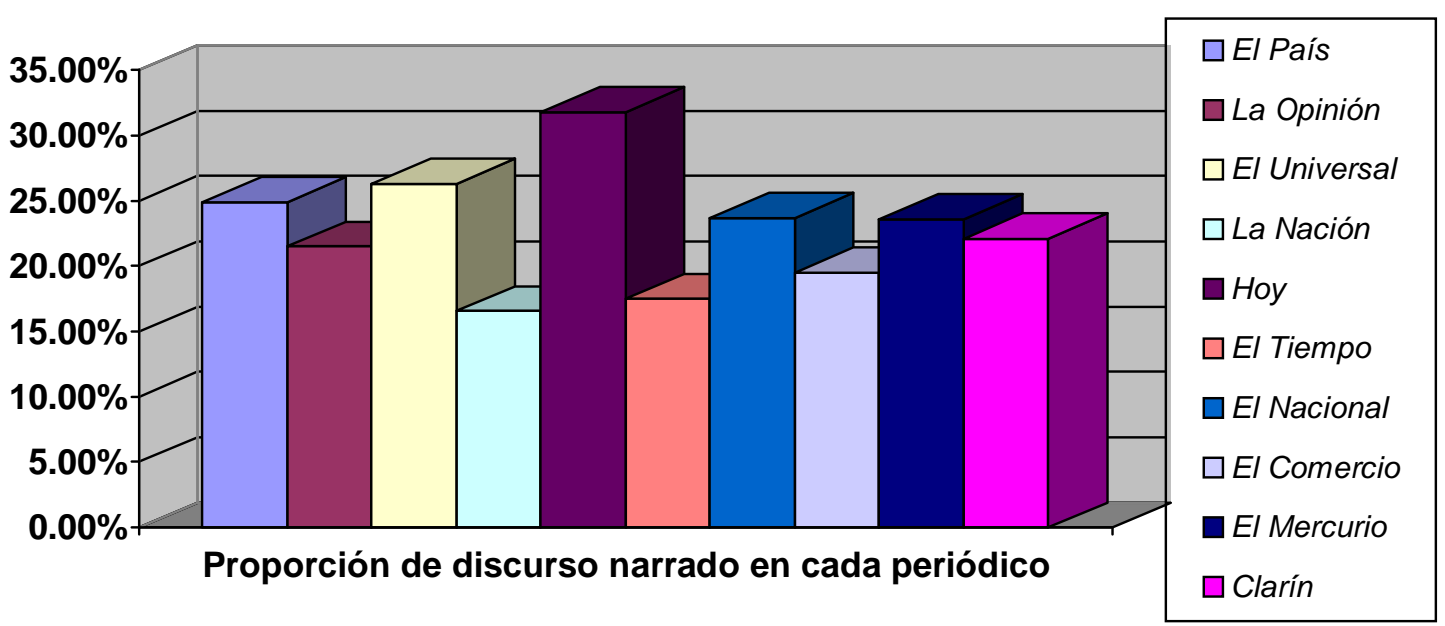

El 75,1\% (655/872) de los testimonios de discurso narrado corresponde a oraciones simples; el 20,8\% (181/872), a oraciones con infinitivo objetivo, y solo el $4,1 \%(36 / 872)$ a frases nominales.

\subsection{Oraciones simples}

La capacidad del discurso narrado de codificarse como oración simple es un rasgo que lo distingue claramente de las variedades marcadas con verbo de habla 
—expreso o elíptico - de los discursos directo e indirecto. No hay oposición pertinente con las formas no marcadas o sin verbo de habla, pues el discurso narrado siempre es denunciado por verbos de este tipo o derivados nominales de ellos.

La gran mayoría de titulares en discurso narrado se codifica como oraciones simples. He clasificado dichos testimonios de acuerdo con los criterios introducidos por Cano Aguilar ${ }^{62}$ para caracterizar la transitividad de las oraciones: registro titulares que ostentan estructuras intransitivas y con transitividad directa y prepositiva (o de régimen prepositivo). Los casos de transitividad directa son los más abundantes.

Sin pretender agotar el asunto, propongo en las siguientes páginas una caracterización semántico-pragmática general para cada uno de estos grupos, atendiendo sobre todo a los diferentes verbos de habla registrados en mi corpus. Tales verbos gozan de especial prominencia en el discurso narrado, pues constituyen la única marca de discurso ajeno en los casos, abrumadoramente mayoritarios, de encabezados con estructuras predicativas; aún mayor es su relieve por el hecho de que, por lo general, los titulares periodísticos tienden a ser formulados en construcciones hiperbáticas que sitúan el núcleo del predicado en posición focal, es decir, al principio del enunciado.

Lo que a continuación presento no es un estudio exhaustivo del dominio léxico de los hechos de habla, sino una descripción general de las marcas de discurso narrado en los titulares periodísticos, con la única pretensión de señalar algunos valores noticiosos que den cuenta de ciertos procesos de selección y codificación informativa seguidos por los periodistas. Atiendo para ello a la oposición establecida por la presencia o ausencia de proyecciones futuras, asociadas

${ }^{62}$ Cano Aguilar 1981. 
— cuando las hay— a la representación o alusión del supuesto contenido del enunciado originario.

Casi exclusivamente, dichas proyecciones resultan, en la mayoría de los casos, de la selección de verbos de habla cuyo semantismo de base apunta a acciones venideras o potencialmente venideras, como ocurre en (4a) y (4b); en otros, la causa del rasgo de futuridad estriba en diversos tipos de relaciones contextuales. El testimonio (4c) carece de proyecciones futuras evidentes.

(4) a. Cristina anuncia la creación del Fondo [CLA 24/01/10: 6]

b. Felipe Larraín adelanta las metas y prioridades del nuevo gobierno de Piñera [MER 19/01/10: B1]

c. Lula responsabiliza a madereros del asesinato de una monja [JOR 23/02/05: 33]

\subsubsection{Verbo transitivo}

Los más abundantes son los testimonios de predicación transitiva directa: representan el 93,4\% (613/655) de los titulares de discurso narrado estructurados en oraciones simples. De estos casos, el 48,6\% (298/613) contiene algún rasgo de proyección futura del supuesto contenido del enunciado originario, mientras que el 51,4\% (315/613) restante no presenta rasgos de futuridad. Este equilibrio parece revelar una tendencia de los titulares en discurso narrado a ser empleados para seleccionar y destacar, del discurso de un Loc 2, la información venidera o potencialmente venidera, en lugar de aquella referida al presente o al pasado, pues los supuestos contenidos del enunciado primitivo carentes de proyección futura no alcanzan sino apenas la mitad de los casos. 


\subsubsection{Futuridad}

Recojo 298 los titulares con rasgos de futuridad asociados a la representación o alusión del supuesto contenido del enunciado de Loc 2. Distingo cuatro grupos, de acuerdo con las características que Loc 1 atribuye, denotativamente, al acto de habla ajeno.

1. Denotación de 'anuncio o advertencia' (98 ocurrencias). En estos casos, Loc 1 manifiesta que Loc 2 ha hecho saber a alguien que va a ocurrir algo, sin especificar de manera explícita si Loc 1 y el agente potencial son correferentes o no. Son prototípicos los casos que presentan verbos como advertir, anunciar, anticipar, predecir y pronosticar. Anunciar es el más frecuente en mi corpus.

(5) a. Piñera anuncia la venta de Lan Chile en plena polémica por subida de acciones [ELP 21/01/10: 7]

b. Obama anticipa mayor regulación a los bancos [UNI Viernes 22/01/10: B1]

c. ATLAS ADVIERTE AL CAMPEÓN MEXICANO [OPI 21/01/10: $2 \mathrm{C}]$

d. Novak pronostica caída de Federer [COM 18/01/10: DT-11]

e. Vaticinan más sismos Haití y resto del Caribe [HoY 23/01/10: 1A]

2. Denotación de 'ofrecimiento o promesa' (27 testimonios). De acuerdo con Loc 1, Loc 2 se ha comprometido a hacer algo o a hacer que se haga algo, ya sea como respuesta a la voluntad de un tercero o no. Son usuales los verbos ofrecer, prometer, garantizar y comprometerse.

(6) a. Gobierno prometió \$ 9,9 millardos para obras eléctricas en el exterior [ELN 20/01/10: A4]

b. Senegal ofrece tierras a los haitianos [ELP 19/01/10: 8]

c. Guardiola da su palabra [OPI 21/01/10: 6C] 
3. Denotación de 'mandato o solicitud' (128 ejemplos). Según la interpretación expresada por Loc 1, Loc 2 ha dicho, con mayor o menor autoridad o respeto, que se haga algo. Es este el contenido conceptual de verbos como recomendar, sugerir, pedir, ordenar, demandar y exigir. Pedir es el más frecuente en mis materiales.

(7) a. Alemania pide arresto de exdictador argentino Videla [LAN 23/01/10: 23A]

b. Transportistas exigen alza de $100 \%$ en el pasaje [ELN 22/01/10: A1]

c. El Congreso de EEUU reclama una drástica reforma de la SEC [MUN 07/01/09: 35]

d. Lugo ordena la intervención del Ejército [СОм 21/01/10: B10]

e. Aconseja paciencia en los vuelos [OPI 18/01/10: 6A]

4. Denotación de 'aceptación o rechazo de sucesos potenciales' (45 casos). Loc 1 señala que Loc 2 ha negado o admitido la posibilidad o la idea de que ocurra algo. Registro verbos como aprobar, autorizar, rechazar y descartar. Son más abundantes los titulares cuyo significado denotativo apunta al rechazo.

(8) a. Bruselas aprueba la compra de Sun [ELP 22/01/10: 20]

b. Haití rechaza el envío de soldados dominicanos [HOY 21/01/10: 4A]

c. Pakistán descarta nuevas ofensivas contra los talibanes [ELP 22/01/10: $11]$

\subsubsection{No-futuridad}

Son 315 los titulares en discurso narrado con verbo transitivo que carecen de rasgos de proyección futura. En todos ellos, Loc 1 refiere que un Loc 2 ha aludido a procesos, acciones o estados pasados o presentes. Registro diez grupos 
de significados denotativos diferentes vinculados con la representación narrativizada del acto de habla ajeno:

1. Denotación de 'crítica, desaprobación o protesta' (66 encabezados). En estos casos, Loc 1 dice que Loc 2 ha manifestado una opinión desfavorable con respecto a algo o alguien. Recojo verbos como criticar, descalificar, reprobar, condenar, repudiar, censurar y fustigar. El primero es el más abundante en mi corpus.

(9) a. Pérez de Cuéllar critica a Fujimori [COM 22/01/10: A7]

b. Barack descalifica sentencia [UNI 24/01/10: A24]

c. Matos Berrido repudia agresión de José Offerman [HOY 18/01/10: 3B]

d. Fustigan diputados proceder de Cárdenas Jiménez [LAP 24/02/05: 29]

2. Denotación de 'aprobación, elogio o jactancia' (53 testimonios). Según Loc 1, Loc 2 ha expresado su conformidad o aprobación con respecto a alguna entidad, que puede ser él mismo. Dicho contenido conceptual es expresado por verbos como celebrar, elogiar, enaltecer, ensalzar, alabar, felicitar y presumir.

(10) a. AmCham felicita al Gobierno [LAN 18/01/10: 12A]

b. El presidente de la AMA alaba plan [ELN 20/01/10: B7]

c. Adrián Uribe presume su reconciliación amorosa con la actriz Marimar Vega [UNI 18/01/10: K5]

d. Pelé se enaltece [OPI 18/01/10: 5C]

3. Denotación de 'acusación o denuncia' (43 casos). De acuerdo con la interpretación presentada por Loc 1, Loc 2 ha atribuido a alguien cierta culpa en un delito o falta. Se presenta normalmente con verbos como acusar, culpar, denunciar e incriminar. En mis materiales, denunciar registra el mayor número de ocurrencias. 
(11) a. Denuncian descontrol de gastos en Aerolíneas por los aviones [CLA 18/01/10: 1]

b. Culpan a Granda [REF 24/02/05: 26A]

c. Enríquez-Ominami acusa falta de coraje en líderes de la Concertación [MER 18/01/10: C23] ${ }^{63}$

4. Denotación de 'aceptación o rechazo de acusaciones o denuncias' (44 ocurrencias). Loc 1 refiere que Loc 2 ha negado o admitido la posibilidad de ser culpable de un delito o falta que alguien le ha atribuido. Registro verbos como aceptar, admitir, reconocer, rechazar, negar y deslindarse. Son más abundantes los encabezados que denotan 'rechazo'.

(12) a. EEUU reconoce errores del sistema de seguridad [HOY 21/01/10: 13B]

b. Samper rechaza acusación de 'Rasguño' [тРо 22/01/10: 1-3]

c. Washington niega ocupación [ELN 22/01/10: A10]

5. Denotación de 'justificación, defensa o apoyo' (31 encabezados). Loc 1 dice que Loc 2 se ha manifestado —exponiendo razones o no- a favor de algo o alguien que ha sido combatido o criticado por otros. Recojo verbos como apoyar, respaldar defender y justificar. El de mayor incidencia en mis materiales es defender.

(13) a. El Papa justificó el polémico silencio de Pío XII ante el Holocausto judío [CLA 18/01/10: 23]

b. Penélope Cruz defiende con fervor a Almodóvar [UNi 21/01/10: K6]

c. Otra McCain apoya las bodas gay [ELP 22/01/10: 36]

6. Denotación de 'expresión de solidaridad, tristeza o contrariedad' (4 ejemplos). En conformidad con la interpretación de Loc 1, Loc 2 ha

${ }^{63}$ Los casos de transitividad directa con el verbo acusar no son, en absoluto, aislados. Puede advertirse que dicho verbo tampoco rige preposición en los ejemplos siguientes:

HRW acusa aumento de abuso militar [UNI 24/01/10: A2]

Estrella acusa autoridades complicidad narco [HOY 18/01/10: 10A]

Acusan vecinos daños en casas por obras [UNI 25/02/05: C9]

Acusan peculado en IEE yucateco [REF 27/02/05: 18A] 
expresado verbalmente cualquiera de estos sentimientos o estados de ánimo. En la mayoría de los titulares, dicha denotación no depende exclusivamente del contenido conceptual del verbo, sino de la relación verbo-objeto, como en estos ejemplos:

(14) a. El sector empresarial expresa solidaridad a Haití [HOY 23/01/10: 2D]

b. Externan condolencias [REF 25/02/05: 5A]

7. Denotación de 'expresión de gratitud' (20 titulares). Según Loc 1, Loc 2 ha manifestado verbalmente su reconocimiento por un beneficio o gesto amable que ha recibido de otra persona. Aunque registro la expresión dar (las) gracias, lo más frecuente en los encabezados es el uso del verbo agradecer:

(15) a. Agradecen a Ecuador acción contra las FARC [COM 24/01/10: B2]

b. Canadá agradece a RD servicio médico a los heridos suyos [HOY 18/01/10: 14A]

c. AGRADECEN CONDOLENCIAS [MER 19/01/10: A6]

8. Denotación de 'revelación' (15 testimonios). En estos casos, Loc 1 refiere que Loc 2 ha dado a conocer información que, de acuerdo con Loc 1, se mantenía oculta o en secreto. Recojo únicamente encabezados con el verbo revelar:

(16) a. El confesor de Michael Jackson revela sus secretos [ELP 24/01/10: 29]

b. El doctor de Elvis revela los difíciles últimos días del "Rey del Rock" [MER 20/01/10: A1]

c. AyA revela alta concentración de materia fecal en seis playas [LAN 18/01/10: 4A] 
9. Denotación de ‘autodescripción' (6 ocurrencias). Loc 1 dice que Loc 2 se ha descrito a sí mismo de determinada manera. Recojo únicamente los verbos decirse, declararse y confesarse. El más frecuente es el segundo:

(17) a. Sergio Andrade se dice inocente en audiencia [UNI 22/02/05: E1]

b. Organización se declara defraudada con Obama [HOY 21/01/10: 13B]

c. Se declara culpable [COM 21/01/10: C16]

10. Denotación genérica del acto verbal (33 encabezados). En este grupo de testimonios, Loc 1 refiere de manera inespecífica, relativamente neutral, que Loc 2 ha realizado un acto verbal. Si bien es cierto que todo enunciado está orientado hacia determinadas conclusiones, ${ }^{64}$ que pueden ser favorables — como en (18a) y (18b) — o desfavorables — como en (18c)—, estas no son explícitas, y por tanto tampoco son denotadas, al menos en los titulares aquí estudiados.

(18) a. Productores relatan beneficios obtenidos [HOY 18/01/10: 2E]

b. Starbucks reporta ganancias [UNI 21/01/10: B3]

c. Cristina llamó al presidente electo recién ayer a la tarde [CLA 19/01/10: 17]

\subsubsection{Verbo prepositivo}

A ejemplos de transitividad prepositiva ${ }^{65}$ corresponde el $5 \%(33 / 655)$ de los testimonios de discurso narrado codificados como oraciones simples. ${ }^{66}$ En el $33,3 \%$ (11/33) de casos de régimen prepositivo se distingue algún rasgo de proyección futura del supuesto contenido del enunciado secundario; el restante $66,7 \%(22 / 33)$ carece de rasgos de futuridad.

\footnotetext{
${ }^{64}$ Cf. Ducrot (1972) 1982, 1980, (1984) 1986, Anscombre y Ducrot 1983.

${ }^{65} \mathrm{Cf}$. Cano Aguilar 1981.

${ }^{66}$ Para una revisión de los criterios definitorios de los objetos prepositivos, $c f$. Cano Aguilar 1999.
} 
He incluido en este grupo los escasos ejemplos de doble complementación ${ }^{67}$ - tanto directa como prepositiva-, es decir, construcciones como (19). Esto no supone sesgos dignos de consideración, pues dichas secuencias presentan una incidencia muy reducida en mis materiales; además, dada la abrumadora predominancia de titulares con transitividad directa, tales casos resultan poco significativos desde un punto de vista estrictamente estadístico.

(19) Israel acusa a Siria de atentado [UNI 27/02/05: A5]

Conviene recordar que, como bien ha señalado Cano Aguilar, "prácticamente todos los verbos [de régimen prepositivo] que significan 'proferir un enunciado', pero que no lo reproducen en principio, los verbos del tipo hablar, rigen un complemento que indica el 'tema' o 'asunto' de ese enunciado". 68 Este complemento —añade- es introducido, de manera prototípica, por la preposición de. En estos casos de discurso narrado en particular, la reformulación analítico-temática de las palabras de Loc 2 es a tal punto sintética que se reduce a un complemento preposicional o suplemento del verbo.

\subsubsection{Futuridad}

Registro 11 encabezados que presentan rasgos de futuridad asociados a la representación o alusión del supuesto contenido del enunciado originario. A partir de los significados denotativos que Loc 1 atribuye al acto de habla de Loc 2, distingo aquí dos grupos de encabezados, también presentes en la categoría de transitividad directa.

\footnotetext{
${ }^{67}$ Cano Aguilar 1999: 1836

${ }^{68}$ Ibid.: 1831.
} 
1. Denotación de 'Anuncio o advertencia' (7 casos). Loc 1 refiere, en estos casos, que Loc 2 ha hecho saber a alguien que va a ocurrir algo, sin especificar de manera explícita si Loc 1 y el agente potencial son correferentes o no. Registro secuencias como alertar de, advertir de, advertir sobre y prevenir de (las negrillas son mías):

(20) a. Alertan de la quiebra en el agro por TLC con Japón [JOR 21/02/05:

17]

b. Previenen al Senado de riesgos por voto mexicano en el extranjero [LAP 27/02/05: 27]

c. Gates advierte de riesgo terrorista al sur de Asia [UNI 21/01/10: A24]

2. Denotación de 'mandato o solicitud' (4 testimonios). De acuerdo con la interpretación que Loc 1 expone, Loc 2 ha dicho, con mayor o menor autoridad o respeto, que se haga algo. La secuencia llamar a es la secuencia más abundante tanto en los corpus piloto como en la muestra cuantificada (las negrillas son mías):

(21) a. Llama a la unidad [UNI 24/02/05: A10]

b. Llama el presidente guatemalteco al libre tránsito en la frontera con México [SOL 23/02/05: 19/A]

c. Propugnan por un pacto eléctrico sostenible [HOY 20/01/10: $1 \mathrm{~A}]^{69}$

\subsubsection{No-futuridad}

Carecen de rasgos evidentes de proyección futura 22 titulares con objeto prepositivo de régimen verbal. Identifico tres grupos - presentes todos en la categoría de transitividad directa-, de conformidad con las características que

\footnotetext{
${ }^{69}$ Por analogía con pugnar por. Destaca este uso en un diario que tiende claramente a la omisión de preposiciones en sus titulares.
} 
Loc 1 atribuye, denotativamente, al acto de habla de Loc 2. Son los siguientes (las negrillas son mías):

1. Denotación de 'acusación o denuncia' (8 ocurrencias). En estos casos, Loc 1 señala que Loc 2 ha atribuido a alguien cierta culpa en un delito o falta. Recojo las secuencias acusar de y responsabilizar de; la primera es la más abundante. Presentan doble complementación todos los ejemplos de este grupo.

(22) a. Simon culpa a Humala de críticas en Bolivia [COм 24/01/10: A15]

b. Los GRAPO acusan a su ex líder del asalto mortal a un furgón [ELP 19/01/10: 16]

c. Lula responsabiliza a madereros del asesinato de una monja [JOR 23/02/05: 33]

2. Denotación de 'crítica, desaprobación o protesta' (5 titulares). Según la interpretación que Loc 1 presenta, Loc 2 ha manifestado una opinión desfavorable con respecto a algo o alguien. Registro las secuencias arremeter contra, protestar contra, cargar contra y quejarse de. Como es natural, destaca el uso de la preposición contra (cuyo término no indica 'tema' o 'asunto' del enunciado ajeno, sino el objeto de las críticas, desaprobaciones o protestas).

(23) a. Cristina cargó contra las telefónicas [CLA 20/01/10: 12]

b. Hugo Chávez arremete contra Colombia [UNI 18/01/10: A26]

c. Kate Hudson se quejó de la poca comida servida en Globos de Oro [HOY 20/01/10: 2D]

3. Denotación genérica del acto verbal ( 9 ejemplos). Loc 1 refiere de manera inespecífica, relativamente neutral, que Loc 2 ha realizado un acto verbal. Registro las secuencias hablar de, informar de, informar sobre y notificar de. 
(24) a. ETA habla de lucha política [ELN 18/01/10: A10]

b. Informan a Internacional Socialista de crisis en el país [ELN 21/01/10: A3]

c. Notifican a accionista de VTR de demanda de la FNE [MER 22/01/10: B8]

\subsubsection{Verbo intransitivo}

Recojo solamente nueve casos de construcciones intransitivas, correspondientes al $1,4 \%(9 / 655)$ de los encabezados en discurso narrado codificados como oraciones simples. Los titulares de esta clase a menudo no vehiculan información sobre el contenido del enunciado de Loc 2. A lo sumo se describe la fuerza ilocucionaria del acto de habla o se especifica el modo o el medio por el fue realizado:

(25) a. Astronautas twittean desde el espacio [MER 24/01/10: A17]

b. Colegios opinan [HOY 23/01/10: 9A]

c. La UE amenaza [А В C 08/01/09: 22]

c. Volqueteros, sepultureros y policías protestaron [ELN 19/01/10: C7]

d. Isabel II habla en la ONU por primera vez en 53 años [MER 24/01/10: A10]

A propósito de un ejemplo similar procedente del Cantar de mio Cid_Fabló con los de Castejón-, Girón Alconchel se pregunta: “¿Seguiremos hablando de $\mathrm{D}$ [iscurso]N[arrado]? He aquí un caso límite que, por lo demás, ilustra acerca de la gradualidad de las formas de D[iscurso]R[eferido]". ${ }^{70}$ Se trata, efectivamente, de un caso límite; pero el hecho de que no haya representación discursiva no implica, desde luego, que no se describa un acto discursivo ajeno. Además, puede decirse que el significado léxico de todos los verbos de habla, ya sean transitivos, prepositivos o intransitivos, supone invariablemente un discurso.

\footnotetext{
${ }^{70}$ Girón Alconchel 1989: 96.
} 
Parece, pues, que esta variedad del discurso narrado se sitúa en el extremo menos mimético -y, por ende, más diegético- del continuum que integran todas las variedades del discurso ajeno.

\subsection{Oraciones con infinitivo objetivo}

Cuando en el discurso narrado el objeto directo o prepositivo está expresado por una oración, esta es siempre de infinitivo. ${ }^{71}$ La oración subordinada supone entonces una representación discursiva analítica, paralelismo este con el discurso indirecto marcado que ha llevado a algunos investigadores ${ }^{72}$ a hablar de "casos límite" — también aquí- entre ambas variedades del discurso ajeno. Las Academias incluso equiparan construcciones de discurso narrado e indirecto con conjunción y verbo subordinante explícitos: "Confesó ser anabaptista equivale a Confesó que era anabaptista". 73

Si bien es verdad que en este ejemplo las Academias apelan a la simultaneidad del infinitivo con respecto al verbo principal, resulta necesario hacer ciertas precisiones, dado el hecho de que se trata de la única alusión que hacen a este problema en su Nueva gramática. En primer lugar, las Academias aciertan en detectar que la construcción con infinitivo es una forma de discurso ajeno - $\mathrm{a}$ diferencia de algunos investigadores que la descartan a priori-, pues de lo contrario no propondrían esa paráfrasis. En segundo, no parecen considerarla, al menos en esta obra, una "variante sintagmática"74 del discurso indirecto por cuanto omiten el tema en su pormenorizada caracterización de los discursos

\footnotetext{
${ }^{71}$ Como se sabe, las oraciones subordinadas de infinitivo en función de complemento verbal pueden actuar "bien sea como un objeto directo, bien sea como un objeto introducido por preposición" (Hernanz 1999: 2277).

${ }^{72}$ Por ejemplo, Fonte 1998: 36.

${ }^{73}$ RAE y AALE 2009: §26.4n

${ }^{74}$ Girón Alconchel 1989: 76.
} 
directo e indirecto en oraciones subordinadas sustantivas ${ }^{75}$ y dado que admiten el valor verbal de estos infinitivos. ${ }^{76}$ Sin embargo, no por ello la postura académica deja de ser ambivalente e incluso contradictoria. En su nueva Ortografía anotan lo siguiente al dictar una norma sobre el uso de comillas dentro de enunciados "en estilo indirecto":

También se encierran entre comillas las palabras textuales que se reproducen dentro de un enunciado en estilo indirecto:

"Desde Medicus Mundi reconocieron ayer sentir impotencia y congoja' por este asesinato y exigieron 'un compromiso de las autoridades para el esclarecimiento de estos graves hechos","77

Dejando de lado el asunto de los segmentos entrecomillados, que trataremos en el capítulo siguiente, lo que de momento interesa es que se presenten como "enunciados en estilo indirecto" secuencias como Reconocieron sentir impotencia y Exigieron un compromiso de las autoridades. No deja de sorprender el segundo caso, pues la doctrina académica siempre ha tratado los problemas relacionados con los discursos directo e indirecto como fenómenos de subordinación sustantiva. Admitir que se trata de un caso de discurso indirecto implicaría admitir que el discurso indirecto con verbo de habla puede presentarse como oración simple y que, por tanto, no necesariamente representa palabras ajenas (pues ejemplos como [18c], [23a], [23b] y todos los de la serie [25] habrían de ser considerados también discurso indirecto). Es una contradicción evidente, ya que, según la definición formulada por las propias Academias, en el discurso indirecto "se reproducen las palabras pronunciadas adaptándolas al sistema de referencias deícticas del hablante". ${ }^{78}$

\footnotetext{
${ }^{75} C f$. RAE y A ALE 2009: $\$ \$ 43.9$ y 43.10 .

${ }^{76}$ RAE y AALE 2009: $\$ 22.6$ a.

${ }^{77}$ RAE Y AALE 2010b: cap. III, \$3.4.8.1.1.

${ }^{78}$ RAE y AALE 2009: $\$ 43.9 c$. Las cursivas son mías.
} 
Casos como Reconocieron sentir impotencia sí representan las palabras ajenas desde el eje deíctico de Loc 1, lo cual, per se, solo implica que no se trata de una forma de discurso directo. Dado que las Academias admiten el valor verbal de estos infinitivos, resulta significativo el hecho de que eviten sistemáticamente el asunto en su caracterización del discurso indirecto como fenómeno de subordinación sustantiva (no es, desde luego, una novedad para ellos, pues por lo menos desde la gramática académica de $1931^{79}$ ya advertían el problema). Dedican, por el contrario, buena parte de su atención a "la forma en que se determina la interpretación de los tiempos en el discurso indirecto", ${ }^{80}$ sin aludir ahí a las evidentes dificultades que plantean los infinitivos. ${ }^{81}$ Eso supone la misma distinción hecha aquí: verbo conjugado subordinado en los casos de discurso indirecto marcado hipotáctico (con la correspondiente conjunción, explícita o no), e infinitivo subordinado en los casos de lo que aquí llamamos discurso narrado.

(26) a. Exigen a la ONU que revise casos de feminicidios [JOR 23/02/05: 43]

b. Piden a ONU revisar casos de muertas en Cd. Juárez [UNI 23/02/05: A17]

En los casos de la serie (26), la alternancia entre pedir y exigir responde a la interpretación del acto ilocucionario que hace Loc 1: bien puede decirse Piden a la ONU que revise casos de feminicidios o Exigen a la ONU revisar casos de muertas en Ciudad Juárez. Por su parte, las diferencias entre revisar casos de feminicidios y revisar casos de muertas en Ciudad Juárez responden a la posibilidad de interpretaciones de re propia de todas las variedades no directas del discurso ajeno. Ahora bien, en contra de lo estipulado por las Academias, parece que, en realidad, no son equivalentes las estructuras Piden (exigen) a la

\footnotetext{
${ }^{79}$ RAE (1931) 1962: $\$ 449 c$.

${ }^{80}$ RAE Y AALE 2009: 43.10n.

${ }^{81} C f$. RAE y AALE 2009 : $\S \S 43.10 \mathrm{~m}-43.10 \mathrm{z}$.
} 
ONU revisar casos de muertas en Ciudad Juárez y Piden (exigen) que la ONU revise casos de muertas en Ciudad Juárez.

Aunque ambas construcciones tienen en común la reformulación analítica del enunciado originario y, por consiguiente, el no-anclaje deíctico en Loc 2, se distinguen desde el punto de vista formal por la presencia de la conjunción subordinante y el verbo subordinado conjugado en el discurso indirecto marcado (caso [26a]), y por el infinitivo y la ausencia de conjunción subordinante en el discurso narrado (caso [26b]). Desde un punto de vista semántico-pragmático, es posible advertir ciertas diferencias si se atiende al principio de que las variaciones formales no son gratuitas, sino que representan opciones del hablante para expresar significados diferentes: en principio, el discurso narrado comporta un mayor distanciamiento por parte de Loc 1, entre otras razones porque, como ya señalaba Jakobson, ${ }^{82}$ el infinitivo es la forma verbal que expresa menos información gramatical (excluye persona, tiempo, número, aspecto). En definitiva, "todo el campo que queda fuera del estilo directo no es uniformemente indirecto". ${ }^{83}$

Hasta donde tengo conocimiento, el infinitivo objetivo no ha sido estudiado en términos de la caracterización del discurso ajeno. En general, se han descrito solo "algunas construcciones notables del infinitivo con ciertos verbos": ${ }^{84}$ con total acierto, se ha dicho, por ejemplo, que el infinitivo aparece como objeto de verbos de percepción sensible (como ver y oír) ${ }^{85}$, de verbos de mandato (como ordenar, pedir y exigir) ${ }^{86}$, de verbos causativos (como hacer $)^{87}$ y de verbos de pensamiento o entendimiento (como pensar, saber y creer $^{88}$.

\footnotetext{
${ }^{82}$ Jakobson (1936-1963) 1981: 324.

${ }^{83}$ Rubio Fernández 1976: 66.

${ }^{84}$ Bello (1847) 1958: §1098.

${ }^{85}$ Bello (1847) 1958: §1100, RAE (1931) 1962: §449a y 1973: §3.16.5a, Luna Traill 1980: 36.

${ }^{86}$ Bello (1847) 1958: §1102, RAE (1931) 1962: §449c y 1973: §3.16.5a, Luna Traill 1980: 3638.
} 
Menos acertada resulta la selección de verbos propuesta por Alcina y Blecua para describir los contextos de las oraciones subordinadas objetivas introducidas por la conjunción que: "Sólo admiten proposición con 'que’ [...] verbos de petición o súplica, como pedir, suplicar, rogar, etc.; verbos de comunicación como adelantar, adivinar, admitir, advertir, agregar, añadir, apuntar, avisar, comentar, concluir, etc.". ${ }^{89}$ Esto significa, en nuestra terminología, que dichos verbos solo se presentan en la forma prototípica del discurso indirecto marcado y no en discurso narrado con infinitivo objetivo. Posición esta parcialmente errónea, a juzgar por los tres primeros ejemplos de la siguiente serie, que no parecen marginales:

(27) a. EE.UU. pide a China investigar Caso Google [Cом 22/01/10: A14]

b. John Edwards admite tener hija con una ex amante [MER 22/01/10: A6]

c. Advierten al obispo de Toluca no extralimitarse en sus opiniones políticas [SOL 21/02/05: 4/B]

d. Wyclef niega sacar provecho de Haití [UNI 18/01/10: K8]

e. Candidata ofrece desnudarse [COм 19/01/10: B9]

f. Aconsejan reducir la publicidad en tv española [JOR 22/02/05: 27]

Los últimos titulares de la serie ejemplifican la posibilidad de otros contextos (registro casos con muchos otros verbos, como asegurar, proponer, plantear, descartar, prometer, exigir, propugnar, aceptar y rechazar). Al respecto, Delbecque y Lamiroy ya han observado que, a causa sus propiedades irregulares, no es predecible la alternancia entre las oraciones subordinadas completivas de infinitivo y las introducidas por que. ${ }^{90} \mathrm{Si}$ bien sugieren la hipótesis de un condicionamiento léxico-sintáctico, en realidad no resuelven el problema.

\footnotetext{
${ }^{87}$ Luna Traill 1980: 38-39.

${ }^{88}$ RAE (1931) 1962: §450b-c, Luna Traill 1980: 39.

${ }^{89}$ Alcina y Blecua (1975) 2001: 8.1.1.1B.e. Cursivas en el original.

${ }^{90}$ Delbecque y Lamiroy 1999: 2029.
} 
Evidentemente, una investigación que lo pretenda excede los límites de este trabajo.

Según Manuel Seco, las construcciones de infinitivo objetivo "son muy frecuentes" en la lengua española. ${ }^{91}$ En mi corpus, dichas estructuras integran el $20,8 \%$ (181/872) de todos los casos de discurso narrado. Registro, como es natural, menos casos de verbos de régimen prepositivo que de verbos cuya complementación no exige preposición alguna; en ambos grupos, los verbos más usuales son, en todos los periódicos, los que denotan 'mandato o solicitud' — pedir, exigir, llamar (a), urgir (a)—, en discordancia con los planteamientos de Alcina y Blecua. ${ }^{92}$

\subsubsection{Verbo subordinante transitivo}

En 133 testimonios, el verbo de habla no exige preposición para introducir el objeto: en términos de Cano Aguilar, son casos de transitividad directa. ${ }^{93}$ Dicha cifra representa el 73,5\% (133/181) de todas las ocurrencias de discurso narrado con infinitivo objetivo. El sujeto del infinitivo es correferente con el de la oración principal en el 23,3\% (31/133) de los casos de discurso narrado con oración de infinitivo en función de objeto directo; no hay comunidad de sujetos en el 76,7\% $(102 / 133) .^{94}$

\footnotetext{
${ }^{91}$ M. Seco 1996: 99.2 .6 .

${ }^{92}$ Alcina y Blecua (1975) 2001: 8.1.1.1B.e.

${ }^{93}$ Cano Aguilar 1981.

${ }^{94}$ En esta materia, el discurso de los titulares se aleja, pues, del español hablado (al menos en la ciudad de México), que presenta una marcada predominancia de sujetos correferentes ( $c f$. Moreno de Alba 2003: 94).
} 


\subsubsection{Concordancia de sujetos}

La relación de correferenecia entre el sujeto del infinitivo y el sujeto de la oración principal se presenta sobre todo en secuencias con verbos regentes que denotan 'aceptación o rechazo', tales como aceptar, admitir, rechazar, negar y descartar, que ejemplifico con los testimonios (26a), (26b), (26c), (26b) y (26d), respectivamente. ${ }^{95}$

(28) a. Gordon Brown acepta declarar ante la comisión por la guerra de Irak [ELP 23/01/10: 9]

b. John Edwards admite tener hija con una ex amante [MER 22/01/10: A6]

c. Vicepresidente argentino rechaza dejar el cargo [LAN 22/01/10: 23A]

d. SEP niega tener agenda electoral [UNI 20/01/10: A5]

e. Gerrard descarta salir del Liverpool [ELN 21/01/10: B5]

Se rastrean también verbos subordinantes que denotan 'ofrecimiento, afirmación o solicitud', como ofrecer, prometer, asegurar y pedir, ejemplificados en la serie (29). Conviene destacar este último verbo, que, en contextos como (29d), rige infinitivo objetivo con sujeto común, no obstante que constituye el lexema verbal prototípico del discurso narrado con infinitivo objetivo y discordancia de sujetos (cf. infra).

(29) a. Candidata ofrece desnudarse [COM 19/01/10: B9]

b. Candidatos prometen dedicar más atención a Centroamérica [LAN 18/01/10: 6A]

c. Asegura Marina tener un bajo número de quejas [UNI 22/02/05: A15]

d. Pide el Senado saber causas de amotinamiento en el Tutelar [LAP 23/02/05: 9]

\footnotetext{
${ }^{95}$ En cuanto a la correferencia de sujetos en oraciones con infinitivo objetivo, $c f$. RAE 1973: \$3.16.4e.3. ${ }^{\circ}$ y Luna Traill 1980: 37 y ss., entre otros.
} 


\subsubsection{Discordancia de sujetos}

El sujeto del infinitivo no es correferente con el sujeto de la oración subordinante en el 76,7\% (102/133) de los encabezados de discurso narrado con oración de infinitivo en función de objeto directo; en la gran mayoría de casos, el infinitivo toma por sujeto el objeto indirecto de la oración subordinante. ${ }^{96}$ Casi todos los titulares de este grupo expresan 'mandato, solicitud o sugerencia'. Esa información suele ser denotada por los verbos subordinantes, como en los siguientes ejemplos:

(30) a. Solicitan a la Alcaldía cancelar contrato de la troncal de TransMilenio por la 26 [тро 23/01/10: 1-19]

b. Recomienda Diego a presidenciables renunciar a sus puestos públicos [SOL 23/02/05: 10/A]

c. Sacerdote sugiere a la Iglesia Católica hacer una modificación urgente sobre la forma de educar [HOY 26/01/10: 6A]

d. Solanas pidió a la Justicia suspender la operación [CLA 22/01/10: 8]

e. Chávez pide a Piñera no meterse con su país [тро 21/01/10: 1-6]

f. Subero exhorta a jueces ser prudentes con medidas coerción [HOY 20/01/10: 13A]

g. IP demanda a Calderón consensuar decisiones [UNI 22/01/10: A5]

h. Sala IV ordena al Incofer bajar volumen de la bocina del tren [LAN 19/01/10: 9A]

i. Exigen a marinos ser bachilleres [ELN 24/01/10: C7]

Distribuidos a lo largo de un continuo ${ }^{97}$ de subjetividad, ${ }^{98}$ estos verbos regentes apuntan a la interpretación del acto de habla ajeno como directivo: ${ }^{99}$ la alternancia de verbos encuentra, pues, su explicación en la lectura que Loc 1 hace del acto de habla ajeno y, en particular, de la fuerza ilocucionaria impresa por Loc 2. Con la selección concreta del verbo de habla - ya lo hemos dicho-, Loc 1 impone al destinatario su interpretación del acto de habla ajeno.

\footnotetext{
${ }^{96} C f$. Hernanz 1999: 2277-2278.

${ }^{97}$ Luna Traill 1980: 36.

${ }^{98}$ Cf. Kerbrat-Orecchioni 1980.

${ }^{99} \mathrm{Cf}$. Searle 1976.
} 
(31) Coinciden castigar a quienes violen derechos humanos de los indígenas [SOL 27/02/05: 8/A]

Puede advertirse que, en casos como (31) — ciertamente marginales—, el componente semántico de 'mandato, solicitud o sugerencia' no está expresado únicamente por el verbo regente, sino por su relación contextual, que, en este caso, sugiere el referente de una solicitud colectiva. A causa, sobre todo, del verbo en presente de subjuntivo y del pronombre relativo, la oración regida por el verboide aporta a la oración de infinitivo el rasgo de proyección futura que se asocia a los actos de habla directivos. Esta carga semántica parece añadirse al valor referencial básico del verbo principal y, por ende, al sentido de todo el enunciado.

\subsubsection{Verbo subordinante prepositivo}

En 48 titulares, la oración de infinitivo desempeña la función sintáctica de objeto prepositivo de régimen verbal, pues el verboide constituye el núcleo de una oración que conforma el término de otra cuyo núcleo es un verbo prepositivo. ${ }^{100}$ Dichos titulares, que representan ejemplos de transitividad prepositiva, ${ }^{101}$ integran el 26,5\% (48/181) de todos los casos de discurso narrado con infinitivo objetivo.

Las predicaciones con transitividad directa e indirecta presentan rasgos semánticos comunes según concuerden o no los sujetos del infinitivo y de la oración principal. La discordancia de sujetos es predominante también en el grupo de predicados con transitividad prepositiva.

\footnotetext{
${ }^{100} C f$. Delbecque y Lamiroy 1999: 3032-2068; Hernanz 1999: 2279-2280.

${ }^{101} \mathrm{Cf}$. Cano Aguilar 1981.
} 


\subsubsection{Concordancia de sujetos}

Presentan sujetos correferentes nueve titulares de discurso narrado con transitividad prepositiva e infinitivo objetivo. Estos encabezados corresponden al 18,8\% (9/48) de los casos con oración de infinitivo en función de objeto prepositivo. Los más frecuentes son los enunciados que denotan 'anuncio o advertencia' —como (32a) - y 'aceptación o rechazo de compromisos potenciales' —como (32b) y (32c)— (las negrillas son mías):

(32) a. Argentina amenaza con estatizar empresa de telecomunicaciones [COM 19/01/10: B5]

b. Piñera se compromete a respetar el legado de la Concertación chilena [ELP 19/01/10: 9]

c. Libertario se niega a revelar documentos sobre créditos [LAN 20/01/10: 5A]

\subsubsection{Discordancia de sujetos}

El sujeto del verbo regente y el del infinitivo no concuerdan en 39 encabezados, que integran el 81,2\% (39/48) de los testimonios de discurso narrado con transitividad prepositiva e infinitivo objetivo. Tal como sucede con los casos de transitividad directa, la mayoría de verbos subordinantes denota 'mandato, solicitud o sugerencia', como puede verse en los ejemplos de la serie (33) (las negrillas son mías). Siempre que esto ocurre, es $a$ la preposición de régimen verbal, pues el rasgo semántico de proyección futura está asociado tanto a la secuencia $a+$ INFINITIVO como a buena parte de las descripciones de actos de habla directivos: 
(33) a. Exhortan a desistir de las pruebas internas [ELN 22/01/10: C3]

b. Anima GB a gays a unirse a la Marina [REF 22/02/05: 25A]

c. Al Qaeda llama a atacar a los judíos [MUN 07/01/09: 27]

d. Papa insta a curas a aporopiarse de Internet [ТРО 24/01/10: 1-10]

e. FCH urge a ubicar mexicanos en Haití [UNI 23/01/10: A8]

Se observa también un sub-grupo minoritario que denota 'acusación o denuncia'. Registro las secuencias acusar de y culpar de en encabezados como los que reproduzco a continuación (las negrillas son mías):

(34) a. Payaso acusó al trapecista de haberlo violado [SOL 27/02/05: 17/A]

b. Acusan a Samper de instigar magnicidio [ELN 21/01/10: A10]

c. PC culpa al BCR de dejarlo sin plata para publicidad [LAN 21/01/10: $8 \mathrm{~A}]$

\subsection{Frases}

Fueron recopilados 36 titulares de discurso narrado estructurados como frases nominales, que representan el 4,1\% (36/872) de los casos de esta categoría contabilizados. La nominalización de un verbo de habla constituye, en todos ellos, el elemento nuclear. He aquí algunos ejemplos:

(35) a. Exhorto a ministros [JOR 22/02/05: 8]

b. Juramento ante la Pachamama [UNI 22/01/10: A28]

c. Condolencias del Ejecutivo por la muerte del gobernador [LAP 26/02/05: 35]

d. Clamor por plan migratorio [OPI 21/01/10: 6A]

En la serie (35), encontramos formaciones sustantivas ${ }^{102}$ de los verbos de habla exhortar, jurar, condolerse y clamar. A pesar de que, en estos casos, se presenta el acontecimiento verbal como estático $-\mathrm{y}$ por consiguiente el texto adquiere propiedades descriptivas-, puede seguir hablándose de discurso narrativo, pues dichos sustantivos no dejan de denotar una acción verbal: recuérdese que la idea

${ }^{102} C f$. Alvar y Pottier 1983: 383. 
de acción, concebible solo en términos de un movimiento temporal que produzca un cambio en la historia relatada, constituye el rasgo definitorio del discurso narrativo, entendido como el procedimiento de representación mediante el cual las transformaciones de una historia son referidas. ${ }^{103}$ De hecho, como afirma Koptjevskaja-Tamm, ${ }^{104}$ las nominalizaciones deverbales ocupan una posición intermedia entre los verbos y los sustantivos típicos, y comparten rasgos semánticos y discursivos con ambos.

En las frases nominales, el discurso narrado encuentra la forma más sintética de referir una enunciación ajena: esta forma de "reducción del discurso al acontecimiento" 105 encierra la finalidad básica de expresar la interpretación del acto ilocucionario que hace Loc 1 y no la de reproducir el contenido proposicional del enunciado de Loc 2, como puede constatarse en los ejemplos de la serie. En suma, con esta variedad de discurso narrado, Loc 1 refiere el acto de habla ajeno de manera global y extremadamente sintética, lo cual evidencia ciertos condicionamientos ideológicos que abordaré en las observaciones finales de este capítulo.

\subsection{Consideraciones finales}

El discurso narrado refiere el acto de habla ajeno como cualquier otro tipo de acción, es decir, sin recurrir a las estructuras de los discursos directo o indirecto marcados, que, como hemos visto, son configuraciones morfosintácticas especializadas en la representación discursiva. Ello explica el hecho de que el discurso narrado suela poner de manifiesto, más claramente que las demás

\footnotetext{
${ }^{103} C f$., entre otros, Barthes 1966, Genette 1966, (1972) 1989 y (1983) 1998, Bal (1978) 1990 y Chatman (1978) 1990.

${ }^{104}$ Koptjevskaja-Tamm 1993: 6.

${ }^{105}$ Genette (1972) 1989: 228.
} 
variedades del discurso ajeno, la interpretación que Loc 1 hace del acontecimiento verbal: en realidad, esta forma de aludir a la enunciación ajena no es sino la expresión narrativizada de la lectura que Loc 1 hace del acto de habla de Loc 2.

El discurso modela patrones interpretativos y formas de pensar a través de procesos que ponen en juego la imagen que los participantes del acto enunciativo se hacen el uno del otro y de los pre-constructos culturales - premisas, representaciones, topoi - sobre los que se basa el acto comunicativo. Los casos de discurso narrado normalmente develan actitudes tendientes a aminorar la importancia de Loc 2, su enunciado o todo el acto de enunciación referido: por sus capacidades reductoras, integradoras y globalizadoras, resulta ideal para aludir a información que se considera poco importante o que se desea disimular. Esto resulta de especial interés en el análisis de los titulares periodísticos, pues, como bien se sabe, orientan la lectura que se hace del texto que encabezan. ${ }^{106}$

Con esto en mente, a nadie extraña que la expresión narrativizada del acto de habla sea, dependiendo del caso, más o menos informativa, bien con respecto al contenido del enunciado ajeno, bien con respecto al acto de enunciación referido. La gradación alusiva al contenido de las palabras ajenas se extiende desde la informatividad nula hasta la especificación completa: en virtud de ello ha quedado demostrado, en páginas anteriores, el error que comporta la arraigada hipótesis de la representación discursiva como criterio definitorio del discurso ajeno. Por el contrario, la designación del acto de habla ajeno depende, en la mayoría de los casos, de la selección del verbo de habla, que puede ser más o menos genérico y, por ende, más o menos valorativo.

(36) a. Hablan de cine [REF 10/01/09: G1]

${ }^{106} C f$. Eco 1977, Van Dijk [1980] 1990, 1983, [1988a] 1997, 2006, Thogmartin 1991. 
b. AGRADECEN CONDOLENCIAS [MER 19/01/10: A6]

c. Exhorto a ministros [JOR 22/02/05: 8]

En los ejemplos de la serie (36), destacan las propiedades reductoras del discurso narrado con respecto a las palabras de Loc 2: puede advertirse que en ninguno de ellos se especifica propiamente el contenido proposicional del enunciado ajeno (capacidad esta ausente en todas las formas de los discursos directo e indirecto). En los casos (36a) y (36b), solo se proporciona el tema o asunto del discurso o enunciado de Loc 2. Esto revela una actitud que podríamos calificar de menospreciativa o encubridora por parte de Loc 1, habida cuenta de las imperantes necesidades de economía de este tipo de discurso y de la posibilidad que ofrece la lengua de emplear otras variedades del discurso ajeno que hemos estudiado, menos sintéticas o generalizadoras. Parece que, a juicio de Loc 1, no conviene reproducir el contenido del enunciado de Loc 2, bien por considerarlo irrelevante, bien por contravenir los intereses de a la organización informativa. Loc 1 no desea, pues, representar ni la forma ni el contenido del enunciado ajeno, sino únicamente referir la ocurrencia de un acto verbal.

En los tres ejemplos puede suponerse, además, una intención encaminada a restar protagonismo a Loc 2, por cuanto este es omitido completamente: en (34a) y (34b), gracias a construcciones impersonales en tercera de plural, y en (34c), a una nominalización deverbal. De especial interés resulta el último caso, pues su escasa informatividad parece responder a motivaciones muy distintas de las que suelen atribuírsele al discurso periodístico: un lector que desatienda el contexto será incapaz de saber quién realizó el exhorto, en qué consistió este o a qué ministros se dirigió el enunciado. Los testimonios (36a) y (36b) ilustran, además, la consabida existencia de grados de precisión en la referencia del acto de habla ajeno (en estos casos, al igual que en la gran mayoría, la designación y especificación del suceso enunciativo depende del verbo de habla). 
Como observan Leech y Short, ${ }^{107}$ el discurso narrado es más indirecto que el discurso indirecto: comporta propiedades analítico-temáticas más acentuadas y, por ende, más reductoras. En palabras de Genette, el discurso narrado es "el estado más distante y, en general, [...] más reductor" ${ }^{" 108}$ del discurso ajeno. Las formas narrativizadas no son, sin embargo, uniformemente indirectas; por eso las he clasificado según el grado de transitividad que contengan: intransitivas, con transitividad prepositiva o con transitividad directa. Evidentemente hay una gradación analítico-temática entre formas como Hablar tonterías (o Decir tonterías), Hablar de algo y Hablar durante tres horas; las estructuras nominales del tipo Discurso de tres horas son, en principio, aún más indirectas que las oraciones intransitivas. El ejemplo (36b) constituye un caso de transitividad directa; el (36a), de transitividad prepositiva, y el (36c), de frase nominal.

He propuesto, con base en los significados denotativos comunes, una clasificación de los titulares en discurso narrado. Independientemente de la transitividad de la oración, se distinguen dos grupos de proporciones equilibradas: los encabezados que presentan rasgos de futuridad y los que no. El primer grupo contiene, básicamente, los enunciados que denotan 'anuncio o advertencia', 'mandato o solicitud' y 'ofrecimiento o promesa'; el segundo, los que denotan 'acusación o denuncia', 'aceptación o rechazo de acusaciones o denuncias', 'crítica, desaprobación o protesta', 'aprobación, elogio o jactancia', ‘justificación, defensa o apoyo', 'revelación', 'expresión de solidaridad, tristeza o contrariedad', 'expresión de gratitud' y 'autodescripción', además de aquellos en los que se denota genéricamente un acto verbal.

\footnotetext{
${ }^{107}$ Leech y Short 1981: 323.

${ }^{108}$ Genette (1972) 1989: 228.
} 
Aunque existe un relativo equilibrio cuantitativo entre ambos grupos, la desproporción en el número de significados denotativos específicos sugiere una tendencia de los titulares en discurso narrado a ser empleados para seleccionar y destacar, del discurso de un Loc 2, la información venidera o potencialmente venidera, en lugar de aquella referida al presente o al pasado. Además, al alcance de Loc 1 hay mucha más información referida al presente o al pasado que al futuro, como es obvio.

El verbo de comunicación (o la nominalización de este) constituye en el discurso narrado la única indicación del procesamiento de un acto de habla ajeno y, también, la expresión de la lectura que Loc 1 impone al destinatario acerca del acto enunciativo ajeno. Las propiedades denotadas resultan, pues, de la siempre subjetiva interpretación de la realidad:

(37) a. Piden menos publicidad en televisión pública española [UNI 22/02/05: A6]

b. Aconsejan reducir la publicidad en tv española [JOR 22/02/05: 27]

Los ejemplos (37a) y (37b), referidos a un mismo acontecimiento verbal, contrastan, entre otras cosas, por los verbos de habla. Ambos titulares describen un mismo acto de habla que, aparentemente, ostentó propiedades directivas: uno y otro denotan 'mandato o solicitud'. La diferencia radica, claro está, en la fuerza ilocucionaria que, según Loc 1, tuvo el acto de habla. El locutor primario de (37b) presenta a un locutor secundario en una actitud más cortés que la descrita por el locutor primario de (37a).

Estructurada en frases nominales o bien en predicados intransitivos o transitivos, el discurso narrado de los titulares periodísticos ofrece ejemplos claros de la subordinación ideológico-persuasiva que rige a todos los modelos y variedades 
del discurso ajeno, ${ }^{109}$ tales como los de la serie (36) y otros que veremos enseguida.

(38) John Edwards admite tener hija con una ex amante [MER 22/01/10: A6]

En este encabezado, Loc 1 refiere que Loc 2 ha admitido una acusación, la cual Loc 1 introduce como un contenido sobreentendido: admitir es, bien se sabe, un verbo factivo. El contenido conceptual de este verbo supone también que Loc 2 ha negado, por lo menos en una ocasión, la información que Loc 1 sobreentiende y que, por tanto, presenta como obvia o universalmente conocida. Tenemos, pues, la siguiente configuración polifónica:

-Pdv1: [X] CIERTo ('John Edwards tiene una hija con una ex amante')

-Pdv2: [E1] INJUSTIFICADO (pdv1)

-Pdv3: [E2] CIERTO ('John Edwards tiene una hija con una ex amante')

Loc 1 es solidario, desde luego, con el pdv1, es decir, con el contenido según el cual se da por cierto que John Edwards - Loc 2- tiene una hija con una ex amante. El contenido léxico del verbo de habla apunta a que Loc 2 ha negado el pdv1 y, por consiguiente, se ha identificado con E1 y ha asumido el pdv2; esto es, en un momento anterior al acto de enunciación reportado, Loc 2 ha pretendido hacer creer que carece de justificación el punto de vista que presenta como cierto el 'tener John Edwards una hija con una ex amante'. El sentido del enunciado indica, no obstante, que Loc 2 finalmente ha reconocido el carácter verdadero del contenido sobreentendido, es decir, ha asumido el pdv3, que posee un valor ilocucionario de aceptación. La asunción de ambos pdv por parte de Loc 2 (y la identificación de este con E1 y E2) es una interpretación pertinente debido a la correferencia que existe entre el sujeto del verbo subordinante y el del infinitivo objetivo.

${ }^{109}$ Cf. Voloshinov (1929) 1992, Bajtín (1935) 1986 y (1963) 1986, Fowler 1986, Fairclough 1988 y 1995b, Hodge y Kress 1993, Van Dijk 2003, entre otros. 
(39) Advierten al obispo de Toluca no extralimitarse en sus opiniones políticas [SOL 21/02/05: 4/B]

En el titular (39), la identidad de Loc 2 es omitida debido al uso de una construcción impersonal con verbo en tercera persona del plural. Con esto, como hemos dicho, se le resta importancia y se evidencia la ideología subyacente de Loc $1 .^{110}$ El contenido del enunciado original, en cambio, es introducido por medio de una reformulación analítica expresada por medio de una oración de infinitivo objetivo, de manera que el texto resulta casi tan informativo como su hipotético correlato en discurso indirecto marcado: Advierten al obispo de Toluca que no se extralimite en sus opiniones políticas. La diferencia semántica, casi imperceptible, radica en que el infinitivo no expresa información de la persona gramatical: ${ }^{111}$ el discurso narrado es —insisto- más indirecta que el discurso indirecto.

-Pdv1: [E1] CIERTo ('Alguien ha ordenado al obispo de Toluca que no se extralimite en sus opiniones políticas')

-Pdv2: [E2] CIERTO ('El obispo de Toluca se ha extralimitado en sus opiniones políticas')

-Pdv3: [LEY] CIERTO ('Los obispos no deben extralimitarse en sus opiniones políticas')

-Pdv4: [E2] CIERTO ('El obispo de Toluca ha cometido un error')

La codificación lingüística del titular revela una estrategia discursiva que se describe en este análisis polifónico. El enunciado (39) contiene, por lo menos, cuatro pdv. El enunciado presenta el pdv2 como presupuesto del pdv1, y el pdv4 como derivado del pdv2 y del pdv3. Este último es introducido como una ley (un tercero colectivo homogéneo), y permite concluir que el obispo de Toluca ha

\footnotetext{
${ }^{110} C f$. Van Dijk 2003.

${ }^{111} C f$. Jakobson (1936-1963) 1981: 324.
} 
cometido un error moralmente censurable. Loc 1 y Loc 2 asumen el pdv4, y se identifican, por tanto, con E2.

(40) Sergio Andrade se dice inocente en audiencia [UNI 22/02/05: E1]

El ejemplo (40), que denota una autodescripción de Loc 2, vehicula tres pdv: uno simple y dos jerárquicos. La lectura que propongo queda representada en el siguiente análisis de la configuración polifónico-argumentativa del sentido expresado por el titular:

-Pdv1: [E1] CIERTO ('Sergio Andrade dice en audiencia que es inocente')

-Pdv2: [E2] CIERTO ('Sergio Andrade es inocente')

-Pdv3: [E3] INJUSTIFICADO (pdv2)

El pdv1, que contiene la información explícita del encabezado, constituye el origen de dos pdv jerárquicos que expresan posturas contradictorias: el pdv2, que apunta a la inocencia de Sergio Andrade, y el pdv3, según el cual tal postura es injustificada. Loc 2 se adhiere al pvd expresado por E2, es decir, pdv2. Loc 1 se identifica, obviamente, con E3, por lo que asume el pdv3. 


\section{FORMAS MIXTAS}

Hemos atendido hasta ahora las variedades puras del discurso ajeno, es decir, aquellas que refieren el enunciado o la enunciación de un locutor secundario de manera directa, indirecta o narrativizada, exclusivamente. Existen, sin embargo, formas discursivas que combinan características de más de una de estas modalidades: reciben el nombre de formas mixtas o híbridas. A todas las que figuran en mis materiales está dedicado el presente capítulo.

Conocidas también como discurso mixto, oratio mixta o enunciados pluriformes, las formas mixtas han sido ignoradas o segregadas por gran parte de los estudiosos del discurso ajeno en sus investigaciones. ${ }^{1}$ Una causa de ello parece ser que los testimonios de estas variedades representan contraejemplos que rebaten algunas de las hipótesis o teorías más aceptadas, como aquellas que asumen el principio de la oposición funcional de los discursos directo e indirecto. ${ }^{2}$ Partee, por citar un ejemplo, admite abiertamente su incapacidad para abordar el asunto y justifica la exclusión que hace en la creencia, acaso errónea, ${ }^{3}$ de que estas formas no se presentan en la expresión oral ordinaria. ${ }^{4}$ Gramáticos hay, en esta corriente, que incluso repudian algunas construcciones híbridas por considerarlas incorrectas. ${ }^{5}$

Han surgido, sin embargo, algunas propuestas de análisis en respuesta a la problemática que plantea negarse a reconocer la vitalidad de estos enunciados,

\footnotetext{
${ }^{1}$ Poe ejemplo, Jespersen (1924) 1968, RAE (1931) 1962: §382 y 1973: §3.19.4, Gili Gaya 1967 §219.II, Partee 1973, Wierzbicka 1974, Alcina y Blecua (1975) 2001: §8.4.1, Bal (1978) 1990, Li 1986, Maldonado 1991 y 1999, y Collins 2001, entre muchos otros.

${ }^{2} C f$., entre otros, Banfield 1973 y (1982) 1995, Comrie 1986, Cate 1996.

${ }^{3}$ Reyes (1993: 8) afirma, por ejemplo, que, cuando se cita mezclando los discursos directo e indirecto, las palabras en discurso directo tienen una entonación diferente en la lengua oral.

4 "My only justification for this [...] exclusion (since intractability is not a justification) is the admittedly prejudiced belief that such sentences do not occur in ordinary spoken language" (Partee 1973: 411).

${ }^{5}$ Gómez Torrego 1997: 386 y 2002: §3.3.4.2, por ejemplo.
} 
que se atestiguan desde el Cantar de mio Cid. ${ }^{6}$ En un momento bastante temprano de la investigación sobre el discurso ajeno, Spitzer $^{7}$ identificó, por ejemplo, la existencia de secuencias en discurso indirecto marcado con verbo y conjunción subordinante que incorporaban segmentos en discurso directo, y las denominó “discurso directo ligado" (discours direct lié). Hoy observamos, por un lado, una inflación terminológica - discurso directo subordinado, discurso indirecto mimético, discurso pseudo-directo, etcétera-, y, por otro, posturas más bien diversas. Así, solo por mencionar un par de casos, Noh opina que las modalidades analítico-discursivas del discurso indirecto (interpretaciones de dicto) podrían considerarse formas mixtas, ${ }^{8}$ y Girón Alconchel asume la existencia de estructuras híbridas en el llamado "estilo indirecto libre" (término que, como hemos dicho, presenta hoy usos ambivalentes). Sin duda, como escribe el propio Noh, las formas mixtas merecen ser objeto de mayor reflexión, en particular desde perspectivas semánticas e incluso filosóficas. ${ }^{10}$

Solo en fechas recientes han empezado a estudiarse de manera relativamente más sistemática las formas mixtas del discurso ajeno, ${ }^{11}$ en especial a partir del fecundo trabajo de Cappelen y Lepore acerca de las variedades de la cita, donde por vez primera se señala la pobreza descriptiva de todo estudio de la representación discursiva que no las considere. ${ }^{12}$ Son pocos, comparativamente, los trabajos anteriores que advierten de modo explícito la necesidad de una categoría de análisis que incluya formas híbridas. ${ }^{13}$

\footnotetext{
${ }^{6}$ Girón Alconchel 1989: 221-269.

${ }^{7}$ Spitzer 1946.

8 "The de dicto reading [...] might be seen as a case of mixed quotation" (Noh 2000: 19).

${ }^{9}$ Girón Alconchel 1989: 75 y 2006: 400.

${ }^{10}$ Noh 2000: 19.

${ }^{11}$ Cappelen y Lepore 1997 y 2005, Tsohatzidis 1998, Rosier 1999, Stainton 1999, Noh 2000, Récanati 2001, Nølke, Fløttum y Norén 2004, entre otros.

${ }^{12}$ Cappelen y Lepore 1997: 446.

${ }^{13}$ Voloshinov (1929) 1992: 178, Schuelke 1958, Davidson (1979) 1984: 90, Authier 1981, Fairclough 1988, Girón Alconchel 1989: 79, Hickmann 1993. En esta primera etapa, los trabajos de Voloshinov y de Authier resultan de no poco valor por sus indiscutibles innovaciones.
} 
Casi todos los trabajos que no ignoran del todo las formas mixtas se centran exclusivamente en el estudio de enunciados que presentan configuraciones sintácticas del discurso indirecto marcado y algún constituyente entrecomillado. ${ }^{14}$ Dicho de otro modo, los especialistas se han ocupado casi exclusivamente de estructuras que ostentan marcas sintácticas del discurso indirecto y marcas ortográficas del discurso directo, similares a la del titular (1a). Como ha evidenciado Rosier, ${ }^{15}$ las formas mixtas son, sin embargo, mucho más numerosas.

(1) a. El Vaticano asegura que la píldora causa "infertilidad masculina" [ELP 05/01/09: 24]

b. Candidata promete ser 'drástica' con reincidentes [LAN 21/01/10: 7A]

c. Venegas se la pasa 'padre' en Viña [REF 23/02/05: 16E]

El origen del problema parece radicar en que, como hemos venido diciendo, casi todos los estudiosos —incluidos los de las formas híbridas - han desechado sistemáticamente de sus análisis las variedades no marcadas y narradas del discurso ajeno. Como resultado, ni siquiera en trabajos muy recientes se concibe la posibilidad de enunciados como (1b) y (1c), que sin embargo, no son inusuales (en realidad, como veremos, son las configuraciones híbridas más frecuentes en los encabezados). En el primero, se registra la inclusión de un segmento en discurso directo marcado dentro de una estructura en discurso narrado con infinitivo objetivo y, en el segundo, un constituyente entrecomillado dentro de un titular en discurso indirecto no marcado.

A partir de las contribuciones de Hickmann relativas a la adquisición de algunas estructuras básicas del discurso ajeno, ${ }^{16}$ concibo y clasifico las formas

\footnotetext{
${ }^{14}$ Por ejemplo, Schuelke 1958, Cappelen y Lepore 1997 y 2005, Tsohatzidis 1998, Stainton 1999, Noh 2000, Récanati 2001.

${ }^{15}$ Rosier 1999. $C f$. Nølke, Fløttum y Norén 2004: 61.

${ }^{16}$ Hickmann 1993.
} 
mixtas según comporten hibridaciones locales o globales. Hay hibridación local cuando una cláusula, ${ }^{17}$ integrada exclusivamente por una frase, oración o período, ${ }^{18}$ registra características de más de una variedad pura del discurso ajeno. Hay, en cambio, hibridación global cuando una cláusula está compuesta por dos frases, oraciones o períodos yuxtapuestos o coordinados que, tomados aisladamente, comportan estructuras identificables con diferentes variedades puras del discurso ajeno.

Todos los casos de la serie (1) son ejemplos de hibridación local, pues presentan la inclusión de constituyentes en discurso directo marcado dentro de enunciados codificados en formas no directas del discurso ajeno. En contraste, los encabezados de la serie (2) son testimonios de hibridación global: en (2a) se coordinan estructuras en discurso indirecto marcado y en discurso narrado $y$, en (2b), configuraciones en discurso narrado y en discurso directo marcado; en (2c), se yuxtaponen secuencias en discurso indirecto marcado (con potencial citativo) y en discurso directo marcado, y en (2d), construcciones en discurso narrado y en discurso indirecto no marcado.

(2) a. La oposición dice que es un triunfo y pide extraordinarias [CLA 20/01/10: 4]

b. La oposición le cantó tres strikes a Chávez y gritó: "Tas ponchao" [ELN 24/01/10: A3]

c. Calderón sería el aspirante; "no creo que Santiago sea el hombre del Presidente", asegura Ramírez Acuña [LAP 24/02/05: 8]

d. Japan Airlines pide protección por quiebra; arranca su reestructura [UNI 20/01/10: B6]

Las formas mixtas son la variedad del discurso ajeno menos abundante en los titulares del mundo hispánico. En mi corpus, su incidencia alcanza apenas una

\footnotetext{
${ }^{17}$ De acuerdo con Lope Blanch (1983: 53) una cláusula es, en la tradición gramatical española, una "expresión con autonomía elocutiva —mejor que sintáctica— derivada de su plenitud conceptual". Se trata, pues, de una unidad de comunicación y, por consiguiente, de pensamiento. Como bien afirma Romero Álvarez (1990: 134), "todos los titulares de un periódico son cláusulas".

${ }^{18}$ En conformidad con los planteamientos de Lope Blanch, entiendo por período una "expresión constituida por dos o más oraciones gramaticales entre las cuales se establece una sola relación sintáctica, ya coordinante, ya subordinante" (Lope Blanch 1983: 35).
} 
media del 3,2\% (118/3689). ${ }^{19}$ El siguiente cuadro contiene la relación de las frecuencias relativas de uso observadas en cada periódico de la muestra cuantificada:

\begin{tabular}{|l|l|}
\hline \multicolumn{1}{|c|}{ Diario } & $\begin{array}{c}\text { Frecuencia relativa } \\
\text { de uso }\end{array}$ \\
\hline El País (Madrid) & $5,1 \%(13 / 253)$ \\
\hline La Opinión (Los Ángeles) & $1,3 \%(2 / 149)$ \\
\hline El Universal (México) & $2,9 \%(18 / 630)$ \\
\hline La Nación (San José de Costa Rica) & $1 \% \quad(3 / 301)$ \\
\hline Hoy (Santo Domingo) & $3,2 \%(17 / 531)$ \\
\hline El Tiempo (Bogotá) & $2,1 \%(6 / 286)$ \\
\hline El Nacional (Caracas) & $1,6 \%(6 / 372)$ \\
\hline El Comercio (Lima) & $0,3 \%(1 / 400)$ \\
\hline El Mercurio (Santiago de Chile) & $7,6 \%(33 / 436)$ \\
\hline Clarín (Buenos Aires) & $5,7 \%(19 / 331)$ \\
\hline
\end{tabular}

Puede advertirse que el santiaguino El Mercurio, el bonaerense Clarín y el madrileño El País superan notablemente la media, representada por el dominicano Hoy (y, en menor medida, por el mexicano El Universal). En realidad, en El Mercurio la frecuencia de uso de formas mixtas supera en más del doble el promedio general. Se observan incidencias menores en el bogotano El Tiempo, el caraqueño El Nacional, el angelino La Opinión, el josefino La Nación y, particularmente, en el limeño El Comercio. De hecho, puede decirse que, en este último diario, la frecuencia relativa de uso de formas mixtas tiende a $0 \%$.

\footnotetext{
${ }^{19}$ Por diarios, la distribución global de las formas mixtas es la siguiente: El País, $11 \%$ (13/118); La Opinión, 1,7\% (2/118); El Universal, 15,3\% (18/118); La Nación, 2,5\% (3/118); Hoy, 14,4\% (17/118); El Tiempo, 5,1\% (6/118); El Nacional, 5,1\% (6/118); El Comercio, 0,9\% (1/118); El Mercurio, 28\% (33/118); Clarín, 16,1\% (19/118).
} 


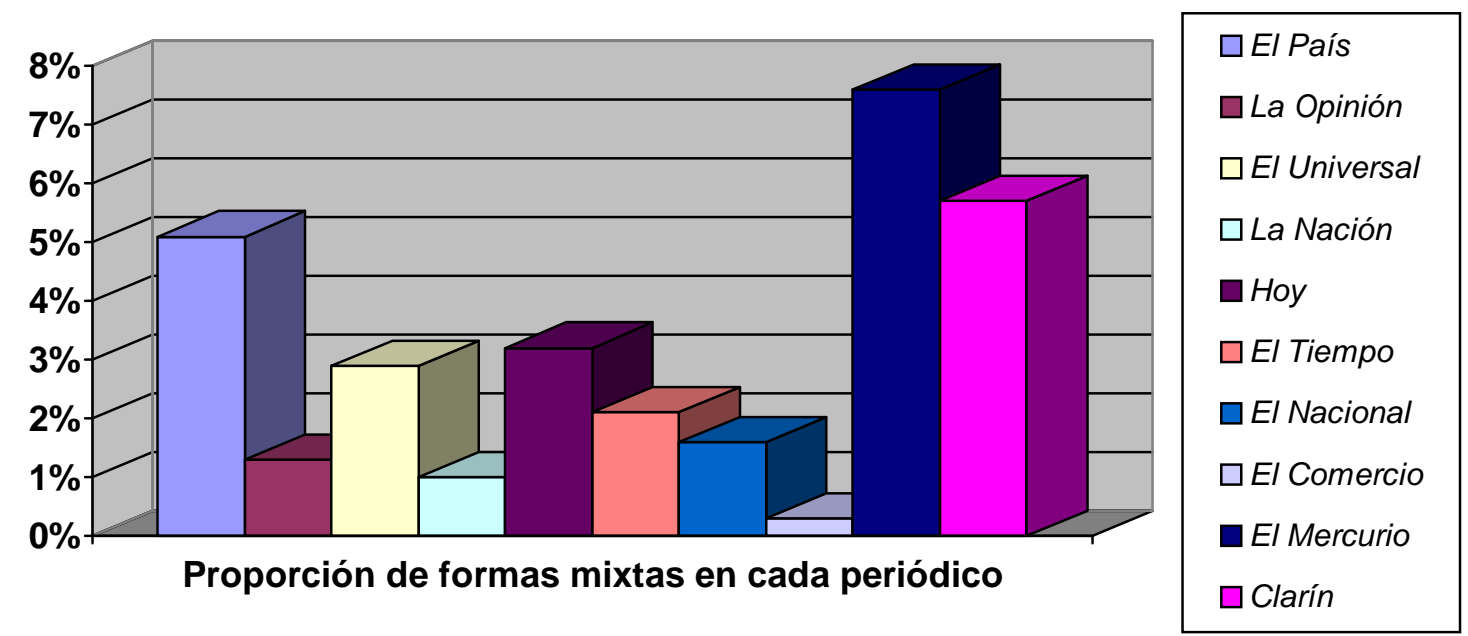

Es evidente que, al menos en los titulares periodísticos, estas formas distan mucho de ser la variedad del discurso ajeno más abundante, como sugieren Cappelen y Lepore. $^{20}$ En mis materiales, el 68,6\% (81/118) de estas estructuras corresponde a casos de hibridación local, mientras que el 31,4\% restante (37/118), a hibridación global.

\subsection{Hibridación local}

Tradicionalmente no codificadas por las gramáticas - e incluso a menudo repudiadas en ellas_-, las configuraciones de hibridación local son, pues, las formas mixtas más frecuentes en mis materiales. Si bien son relativamente usuales en el discurso periodístico, no son exclusivas de este ni se originaron en él: se observan, por ejemplo, en el Cantar de mio $\mathrm{Cid}^{21}$ y en traducciones de la Biblia al latín ${ }^{22}$ (desde luego, también se presentan en muchas otras lenguas, como el inglés, ${ }^{23}$ el francés ${ }^{24}$ y, según Jespersen, el islandés y el griego antiguo). Las hibridaciones locales ni siquiera son, a juicio de Reyes, ${ }^{25}$ exclusivas de la lengua escrita. Son, en definitiva, construcciones habituales

\footnotetext{
${ }^{20}$ Cappelen y Lepore 1997: 429.

${ }^{21}$ Girón Alconchel 1989: 221-269.

22 Bruña Cuevas 1993.

${ }^{23}$ Por ejemplo, Noh 2000.

${ }^{24}$ Spitzer 1948, Authier 1984, entre otros.

${ }^{25}$ Reyes 1984: 81.
} 
en muy diversos usos discursivos, "aunque la Gramática, encerrada en la oración, no haya sabido todavía incorporarlas a su descripción”. ${ }^{26}$

En todas las ocurrencias de hibridación local que registro, una palabra o frase marcada ortográficamente como reproducción literal es introducida en la estructura de alguna forma no directa del discurso ajeno. Dicho de otro modo, en todos los ejemplos de hibridación local, un titular que presenta la estructura general de alguna referencia o retransmisión no directa —es decir, alguna construcción en discurso indirecto o discurso narrado- incorpora un constituyente marcado ortográficamente como discurso directo.

Llamo constituyente incorporado a la palabra, frase u oración que, con marcas ortográficas de retransmisión literal, se introduce en una estructura de retransmisión o referencia no directa. Por el contrario, denomino estructura receptora a la construcción lingüística que dicho segmento acoge como constituyente.

Como marcas ortográficas, registro comillas inglesas y simples, así como letras cursivas. Bien han advertido autores como Polo, ${ }^{27} \mathrm{Catach}^{28}{ }^{28}$ unberg ${ }^{29}$ y Récanati ${ }^{30}$ que tales señales constituyen signos lingüísticos y, en cuanto tales, poseen un significado convencional. En el capítulo correspondiente al discurso directo, hemos recordado que uno de los significados asociados a estas formas es el de retransmisión supuestamente literal de las palabras de un Loc 2.

Los periódicos analizados registran las mismas preferencias por marcas ortográficas de retransmisión literal en las formas mixtas que en los casos de discurso directo marcado. A saber: Clarín, El Mercurio, El País, El Universal

\footnotetext{
${ }^{26}$ Méndez García de Paredes 1999: 128.

${ }^{27}$ Polo 1974.

${ }^{28}$ Catach 1980.

${ }^{29}$ Nunberg 1990.

${ }^{30}$ Récanati 2001.
} 
y Hoy emplean únicamente comillas inglesas; El Tiempo y La Opinión, en cambio, solo utilizan comillas simples. Hay alternancias en La Nación y El Nacional: mientras que el primer diario opta entre comillas inglesas y simples, el segundo se vale de comillas angulares e inglesas, con preponderancia, en ambos casos, por el signo tipográficamente más pequeño. No registro casos de hibridación local en el peruano El Comercio.

Authier ${ }^{31}$ señala que las marcas ortográficas de retransmisión directa pueden constituir señales portadoras de valores enunciativos propios, que se añaden a un fragmento cualquiera de una cadena sintagmática. De manera general, como hemos visto, estas marcas entrañan un distanciamiento de Loc 1 con respecto a las supuestas palabras de Loc 2: Loc 1 no asume por completo la responsabilidad en el uso de esas palabras, "no tanto de su significación como de su connotación". 32 Se muestra entonces una forma de heterogeneidad discursiva compleja que no implica la ruptura del hilo discursivo y que presenta al mismo tiempo a Loc 1 como usuario y observador de las palabras de Loc 2: se trata de lo que Authier, ${ }^{33}$ siguiendo a Rey-Debove, denomina connotación autonímica (connotation autonymique).

Los constituyentes de esta manera incorporados, que la ScaPoLine ${ }^{34}$ llama "islotes textuales", constituyen interferencias léxicas ${ }^{35}$ que, en términos de Clark y Gerrig, ${ }^{36}$ demuestran el modo de expresarse de Loc 2. Para estos autores, la cita literal es una demostración, entendido este término en el sentido etimológico de 'muestra': al entrecomillar ciertas palabras, Loc 1 muestra —o de-muestra - cómo se expresó Loc 2. En otros términos, el constituyente incorporado supone que Loc 1 adopta temporalmente una

\footnotetext{
${ }^{31}$ Authier 1981 y 1984.

32 Pendones 1992: 22. Cf. Fernández Lagunilla y Pendones 1993 y 1997.

${ }^{33}$ Authier 1981: 127.

${ }^{34}$ Nølke, Fløttum y Norén 2004: 77.

${ }^{35}$ Maingueneau 1976: 137; $c f$. Maingueneau 1981: 107.

${ }^{36}$ Clark y Gerrig 1990.
} 
actitud histriónica, ${ }^{37}$ no asociada de modo convencional con la estructura receptora.

En las configuraciones de hibridación local, Loc 1 menciona y usa al mismo tiempo las supuestas palabras de Loc $2 .{ }^{38}$ La palabra, frase u oración ajena se incorpora como constituyente de la estructura receptora: no hay, como dice Maingueneau, ${ }^{39}$ una ruptura sintáctica similar a la del discurso directo marcado con verbo subordinante. De manera simultánea, estas palabras desempeñan una función demostrativa ${ }^{40}$ —es decir, representan la manera de expresarse de Loc 2-, que, en principio, es rechazada por las variedades no directas del discurso ajeno.

Además, como destaca la ScaPoLine, el origen de la expresión demostrada — esto es, la identidad de Loc 2- no suele señalarse de manera explícita en el texto: Loc 1 selecciona a su gusto ciertas palabras del enunciado originario y las introduce de manera histriónica en su propio texto sin especificar de quién es el habla imitada en el constituyente incorporado. ${ }^{41}$ Dicho procedimiento genera, a juicio de estos investigadores, cierta confusión en el lector. ${ }^{42}$

\subsubsection{Estructura receptora en discurso indirecto marcado}

Con toda seguridad, la forma mixta más estudiada ha sido aquella que incorpora el constituyente en discurso directo marcado dentro de una

\footnotetext{
${ }^{37}$ Cf. Wierzbicka 1974: 272.

${ }^{38}$ Cf. Authier 1981: 127, Cappelen y Lepore 1997: 443-445, Récanati 2001: 658.

${ }^{39}$ Maingueneau 1981: 107.

${ }^{40}$ Récanati 2001: 658.

41 'L'important dans ce type, c'est que la source n'est pas explicitement signalée. C'est là le privilège du locuteur : de mettre en scène les paroles à son gré et de nous laisser un peu dans la confusion" (Nølke, Fløttum y Norén 2004: 79).

${ }^{42}$ Como observa Maingueneau (1981: 107), si el texto es leído en voz alta, en realidad es muy probable que el alocutario sea incapaz de detectar la existencia de una supuesta retransmisión literal. Esto se debe, claro está, a que las marcas ortográficas de retransmisión directa (cf. Catach 1980: 22) son propias de lo que Benveniste ([1974] 2002: 91) denomina "enunciación escrita" ( $c f$. Nunberg 1990).
} 
estructura en discurso indirecto marcado: ${ }^{43}$ algunos autores no conciben, en realidad, otras estructuras híbridas. ${ }^{44}$ Suele haber consenso en el hecho, aquí advertido, de que, en estos casos, Loc 1 menciona y usa al mismo tiempo las palabras de Loc 2. Tales investigaciones se oponen, por lo general, a la actitud teórico-metodológica que apunta a una supuesta exclusión mutua de las formas directas e indirectas de la representación discursiva. ${ }^{45}$

Según más de un investigador, este procedimiento híbrido se ha generalizado "en el lenguaje escrito, fundamentalmente en los reportajes periodísticos". ${ }^{46}$ Incluso, para algunos, "esta fórmula reproductora mixta es, sin duda, la más extendida en el discurso periodístico", ${ }^{47}$ por lo que constituye, dicen, la forma mixta prototípica en dicho registro de la lengua. ${ }^{48}$ Mis materiales, sin embargo, indican una tendencia muy diferente para los titulares de la prensa en español: esta estrategia discursiva representa apenas el 12,4\% (10/81) del total de casos de hibridación local.

(3) a. El PP alega que «los líderes de la oposición nunca han tenido una gran valoración» [MUN 08/01/09: 10]

b. Moratinos dice que los rehenes españoles "están bien" [ELP 22/01/10: 14]

c. Que Carlos está 'feliz'... [REF 24/02/05: 4E]

d. «Totalmente inaceptable», según la UE [ABC 07/01/09: 25]

e. Para la oposición, el fallo por las reservas fue un "triunfo" [CLA 23/01/10: 12]

En (3a) y (3b) se observan estructuras receptoras con verbo y conjunción explícitos; en el primer caso, el constituyente incorporado es todo el segmento

${ }^{43}$ Cf. Schuelke 1958, Cappelen y Lepore 1997 y 2005, Tsohatzidis 1998, Stainton 1999, Noh 2000, Récanati 2001, entre otros. Verdín Díaz (1970: 70) la llama "estilo indirecto puro señalado por comillas"; Reyes (1984: 81), "cita directa dentro de la cita indirecta", y Maldonado (1999: 3552), "discurso pseudo-directo".

${ }^{44}$ Por ejemplo, Cappelen y Lepore 1997 y 2005, Noh 2000, Récanati 2001.

${ }^{45} C f$. Banfield 1973 y (1982) 1995, Comrie 1986, Cate 1996.

${ }^{46}$ Gutiérrez Ordóñez 1986: 35. Cf. Reyes 1984: 81 y 1993: 8, Bruña Cuevas 1990: 100, Fonte 1998: 31.

${ }^{47}$ Fernández Lagunilla y Pendones 1997: 88. Cf. Waugh 1995: 146.

${ }^{48}$ Waugh 1995: 148. 
2, mientras que en el segundo se incorpora en discurso directo marcado solo una parte de él. Los encabezados (3c) y (3d) son testimonios de estructuras receptoras con verbo subordinante elidido. En (3e), por último, asistimos a un caso de estructura receptora con la preposición para.

Algunos gramáticos tildan de incorrectas las fórmulas con conjunción expresa, como los titulares (3a), (3b) y (3c): "En los estilos directos sobra siempre la conjunción que". ${ }^{49}$ En su opinión, "son incompatibles la conjunción subordinante que y el estilo directo, a pesar de que ello es relativamente frecuente en el lenguaje periodístico".50 A esta postura se suman algunos libros de estilo — como los de El País y El Mundo-, cuyas directrices, a pesar de tener "un claro componente de obligatoriedad", 51 no siempre son acatadas por los redactores de titulares, como ponen de manifiesto testimonios como (3a) y (3b), que no son, de ninguna manera, casos aislados (no falta, por cierto, quien incluso emita la poco comprensible recomendación de siempre "evitar las comillas" "52 en los titulares). Se lee lo siguiente en el código interno de redacción de El País:

Es una incorrección sintáctica emplear el que cuando se hace una cita en estilo directo. Para expresar las palabras tal como fueron dichas, no se debe utilizar el que, y sí los dos puntos y las comillas. Ejemplo: "Felipe González dijo: 'Ya está bien de obsesiones golpistas". En cambio, en estilo indirecto sobran estos dos signos ortográficos, ha de ponerse el que, y en ocasiones cambia la relación temporal de los verbos. Ejemplo: "Felipe González dijo que ya está bien de obsesiones golpistas"; "Felipe González dijo que ya estaba cansado". 53

Posturas más flexibles — acaso más ceñidas al uso real de la lengua — señalan como recomendable que el constituyente incorporado se ajuste al sistema sintáctico y semántico proyectado por la estructura receptora. Así, por

\footnotetext{
${ }^{49}$ Gómez Torrego 1997: 386.

${ }^{50}$ Gómez Torrego 2002: §3.3.4.2. Cf. Romero Gualda 1994: 33.

${ }^{51}$ Fernández Beaumont 1987: 215.

${ }^{52}$ Rojas Espinosa 2003: 104. Cf. Gómez Mompart 1982: 119.

${ }^{53}$ El País 2003: 127. Cf. El Mundo 1996: 57-58.
} 
ejemplo, las Academias preceptúan: "La inclusión, a través de las comillas, de un texto literal dentro de un enunciado en estilo indirecto es aceptable siempre y cuando no se incumpla alguna de las condiciones impuestas por el estilo indirecto, como, por ejemplo, la correlación de tiempos verbales o los cambios en determinados pronombres o adverbios". 54

Claro está que tras ambas posturas subyace la intención de erradicar el uso discordante de segmentos literales, dado el problema de doble dependencia que en estos casos se presenta. Las discordancias de este tipo son, a pesar de todo, bastante frecuentes en los periódicos, como queda patente en el trabajo de Mittwoch. ${ }^{55}$ En cualquier caso, apunta Gutiérrez Ordóñez, "el carácter literal de estas construcciones permite mayores licencias", ${ }^{56}$ que responden siempre a necesidades concretas de comunicación. Hablaré de ellas en las observaciones finales de este capítulo.

\subsubsection{Estructura receptora en discurso indirecto no marcado}

Recojo 30 titulares en donde el constituyente en discurso directo marcado se ha incorporado a una estructura en discurso indirecto no marcado; estos encabezados integran el 37\% (30/81) del total de casos de formas mixtas con hibridación local. Recuérdese que la reformulación analítica no marcada solo puede interpretarse, en su estado puro, si se atiende al contexto; sin embargo, en los casos que aquí nos ocupan, la marca ortográfica revela ya la existencia de una heteroglosia discursiva. El discurso indirecto no marcado de la estructura receptora pierde, pues, su carácter de "cita encubierta". 57

(4) a. El fraile está "sano y salvo" [CLA 19/01/10: 21]

\footnotetext{
${ }^{54}$ R AE y AALE 2005: s. v. comillas, §2a. Cf. RAE y AALE 2010b: cap. III, §3.4.8.1.

${ }^{55}$ Mittwoch 1985. $C f$. Di Bello y Sapegno 2003: 45.

${ }^{56}$ Gutiérrez Ordóñez 1986: 36.

${ }^{57}$ Reyes 1994b.
} 
b. Dos niños torturaron por diversión "hasta que les dolieron los brazos" [ELP 23/01/10: 29]

c. Seguirá Cuba comprando alimentos a EU "en condiciones aceptables" [sOL 26/02/05: 4/A,2. ${ }^{\mathrm{a}}$ ]

d. Especial compromiso de Fox con los capitalinos [JOR 25/02/05: 5]

Al igual que en los casos de discurso indirecto no marcado puro, la estructura receptora se codifica en frases nominales, como en el encabezado (4d), o en oraciones, como en los testimonios (4a) a (4c). Asimismo, la identidad de Loc 2 puede mencionarse u ocultarse. En cuanto a las marcas ortográficas del constituyente incorporado, registro en la muestra cuantificada únicamente comillas (de distintas clases, según los criterios que ya he descrito). No obstante, en el mundo hispánico existen diarios, como los mexicanos Milenio Diario y La Jornada, que, con la misma función, presentan también letras cursivas (ejemplo [4d]).

\subsubsection{Estructura receptora en discurso narrado}

La fórmula mixta más abundante de mis materiales es aquella que incorpora un segmento en discurso directo marcado dentro de una estructura en discurso narrado. Los testimonios que he reunido integran el 34,8\% (41/118) de todas las formas mixtas y el 50,6\% (41/81) de los casos de hibridación local. Como hemos dicho, en los titulares de la prensa hispánica el procedimiento de hibridación más usado no es, por tanto, la hibridación local en estructuras receptoras en discurso indirecto marcado. Dada la elevada incidencia del discurso narrado como variedad pura del discurso ajeno, no resulta extraña la frecuencia relativa de uso de esta fórmula de hibridación local.

(5) a. Sebastián Piñera promete un 'gobierno buena onda' [TPO 24/01/10: 1-1]

b. Alcalde califica de "acto satánico" las marchas gays [HOY 26/01/10: 6C] 
c. Juez rechaza "por ahora" procesar a Luis Ajenjo [MER 20/01/10: C10]

d. El PP acusa a Álvarez de extender su ineficacia «por tierra, mar y aire» [A В 11/01/09: 20]

En todos los casos de hibridación en estructuras receptoras en discurso narrado, el origen del segmento incorporado concuerda con la entidad a que alude el sujeto gramatical del verbo de habla; esto es, Sebastián Piñera en (5a), el alcalde de Moscú en (5b), un juez chileno en (5c) y el Partido Popular en (5d). Para señalar el extrañamiento del constituyente incorporado, se emplean aquí también, como puede apreciarse en la serie (5), las tres marcas ortográficas de discurso directo presentes en el corpus cuantificado: comillas simples, inglesas y latinas (pueden rastrearse, asimismo, usos de letras cursivas). Los titulares (5a) y (5b) ilustran los casos de oraciones simples. El primero es un ejemplo de transitividad directa, y el segundo, de transitividad prepositiva. Los encabezados restantes son testimonios de infinitivo objetivo, con verbo subordinante transitivo el caso (5c) y con verbo subordinante prepositivo el titular (5d).

\subsection{Hibridación global}

El 31,4\% (37/118) de las formas mixtas corresponde a casos de hibridación global. En ellos se genera una cláusula que enlaza paratácticamente dos segmentos que comportan, por separado, estructuras asociadas a variedades puras del discurso ajeno. ${ }^{58}$ Considero que estos casos son formas híbridas, y no testimonios de varias formas puras, por cuanto integran unidades

${ }^{58}$ Cf. Hickmann 1993. 
comunicativas $^{59}$ que representan o aluden a un mismo acto $-\mathrm{o}$ macro-acto${ }^{60}$ de habla.

He rastreado cinco fórmulas básicas de hibridación global: 1) discurso narrado con discurso indirecto marcado; 2) discurso narrado con discurso indirecto no marcado; 3) discurso narrado con discurso directo marcado; 4) discurso directo marcado con discurso indirecto marcado, y 5) discurso directo marcado con discurso indirecto no marcado. Las más frecuentes son las que combinan discurso narrado con reformulaciones analíticas no marcadas.

\subsubsection{Discursos narrado e indirecto marcado}

El 24,3\% (9/37) de las formas mixtas con hibridación global presenta un segmento en discurso narrado enlazado con otro en discurso indirecto marcado. En los ejemplos (6b), (6c) y (6d), el segmento en discurso narrado precede a la construcción en discurso indirecto marcado. En (6a) la sucede. Los testimonios (6a) y (6b) presentan configuraciones de discurso indirecto con verbo y conjunción explícitos, mientras que en (6c) asistimos a una elipsis de la conjunción completiva. En (6d), por último, se observa un caso de potencial citativo.

(6) a. La oposición dice que es un triunfo y pide extraordinarias [CLA 20/01/10: 4]

b. Miguel pide perdón y dice que no amenazó [MUN 09/01/09: 40]

c. Objetan aumento de navieras a tarifas de fletes; advierten lo pasará usuarios [HOY 23/01/10: 1D]

d. Denuncian supuesto acecho contra una niña en Hidalgo de parte del padre; la querría secuestrar [SOL 21/02/05: 6/B]

\footnotetext{
59 "Todos los titulares de un periódico son cláusulas: constituyen unidades comunicativas" (Romero Álvarez 1990: 134).

60 "Un macroacto de habla es un acto de habla que resulta de la realización de una secuencia de actos de habla linealmente conectados" (Van Dijk [1978] 1998: 72).
} 


\subsubsection{Discursos narrado e indirecto no marcado}

El procedimiento de hibridación global más abundante consiste en coordinar o yuxtaponer un segmento en discurso narrado con otro en discurso indirecto no marcado: representa el 64,9\% (24/37). Esta incidencia no resulta extraña si tenemos en cuenta que los discursos narrado e indirecto no marcado son las variedades puras con frecuencias relativas de uso más elevadas. He aquí algunos ejemplos:

(7) a. Japan Airlines pide protección por quiebra; arranca su reestructura [UNI 20/01/10: B6]

b. Desmiente Diego Fernández a Ebrard; no tiene vergüenza [LAP 26/02/05: 2]

c. Ricky Martin visita al Presidente; anuncia ayuda [HOY 20/01/10: 4A]

En los titulares (7a) y (7b), el segmento en discurso narrado precede a la reformulación analítica no marcada; el fenómeno inverso puede apreciarse en (7c). En las observaciones finales de este capítulo, veremos que casos como (7a) y (7b) suelen comportar una restricción del foco narrativo y, por tanto, de la distancia de Loc 1 con respecto a Loc 2 y al contenido del enunciado secundario.

\subsubsection{Discursos narrado y directo marcado}

El 13,5\% (5/37) de las formas mixtas con hibridación global corresponde a fórmulas que coordinan o yuxtaponen estructuras de discurso narrado y configuraciones que retransmiten de manera supuestamente literal las palabras de Loc 2. En los titulares (8a) y (8b), la secuencia en discurso directo marcado sucede al constituyente en discurso narrado; lo contrario se advierte en el ejemplo (8c). Los casos (8a) y (8c) ostentan marcas dobles de discurso 
directo: tanto sintácticas como ortográficas; el ejemplo (8b) solo presenta, en cambio, indicaciones ortográficas. Puede apreciarse que, en lo concerniente al factor de iconicidad, estas fórmulas registran las transiciones más drásticas: van de un segmento extremadamente diegético a uno mimético, o viceversa.

(8) a. La oposición le cantó tres strikes a Chávez y gritó: "Tas ponchao" [ELN 24/01/10: A3]

b. Obama se lanza contra la Corte Suprema por fallo sobre financiación electoral; "es un golpe a la democracia" [MER 24/01/10: A4]

c. "Cuidado con el populismo", alerta el Presidente y le imputa la crisis de 1994 [JOR 26/02/05: 10]

\subsubsection{Discursos directo marcado e indirecto marcado}

Las formas de hibridación global menos frecuentes en la prensa hispánica son aquellas donde se coordinan o yuxtaponen representaciones literales marcadas y reformulaciones analíticas marcadas. A tal punto es así que no registro casos en la muestra cuantificada, pero no por ello puede decirse que sean anómalos. Del corpus piloto extraigo el testimonio (9). Puede apreciarse que, en este caso, una estructura doblemente marcada como discurso directo es precedida por una forma de discurso indirecto que se identifica como marcada por la conjugación del verbo en condicional o pospretérito con valor de potencial citativo.

(9) Calderón sería el aspirante; "no creo que Santiago sea el hombre del Presidente", asegura Ramírez Acuña [LAP 24/02/05: 8]

\subsubsection{Discursos directo marcado e indirecto no marcado}

En el 2,7\% (1/37) de los testimonios de hibridación global, una forma marcada como directa se coordina o yuxtapone a una reformulación analítica no marcada. Son, definitivamente, mecanismos discursivos poco abundantes. En 
los ejemplos de la serie (10), los segmentos en discurso directo no están marcados por comillas, sino solamente por la relación de subordinación acompañada por pausas (representadas por signos de puntuación), en estructuras propias del discurso de los titulares, como ya hemos dicho. La representación indirecta no marcada precede en (10a) al segmento en discurso directo marcado. Se observa el orden inverso en (10b).

(10) a. Urgen a Pemex 10,000 mdd; sus finanzas están en nivel crítico, dice Ramírez Corzo [LAP 22/02/05: 24]

b. Atender vivos: OMS; muertos contaminan poco [HOY 21/01/10: $6 \mathrm{E}]$

\subsection{Consideraciones finales}

Como sugiere su nombre, las formas mixtas - $\mathrm{o}$ "enunciados pluriformes"- ${ }^{61}$ constituyen fórmulas discursivas que presentan características de más de una variedad pura del discurso ajeno. Hay hibridación local cuando una cláusula, integrada exclusivamente por una frase, oración o período, registra características de más de una variedad pura del discurso ajeno; solo recojo casos en los que una estructura asociada a alguna variedad no directa incorpora, como constituyente, un segmento marcado ortográficamente como discurso directo. Hay hibridación global cuando, en la cláusula, se enlazan paratácticamente frases, oraciones o períodos que, por separado, se interpretan como variedades puras.

En los ejemplos de formas mixtas que recojo, los segmentos asociados a diferentes variedades puras del discurso ajeno tienen como origen un mismo acto o macro-acto de habla y, por ende, un mismo Loc 2. Dicho de otro modo, todos los encabezados que he considerado en el presente capítulo representan

${ }^{61}$ Girón Alconchel 1989: 79. 
o aluden, en cada caso, al discurso de un solo Loc 2. Con respecto a este asunto y a todos los concernientes a la clasificación y caracterización, debo advertir que, si bien me he limitado a describir las formas contenidas en mis materiales, no descarto la posibilidad de otras fórmulas.

La hibridación local es el único procedimiento que ha recibido cierta atención por parte de los especialistas. Ya Voloshinov ${ }^{62}$ identificaba una modalidad discursiva, que él llamó "discurso directo predeterminado", 63 caracterizada por la adecuación sintáctica de estructuras indirectas a fin de dar cabida a un segmento en discurso directo. El interés por estas formas del discurso ajeno, sin embargo, apenas empieza a generalizarse.

Lo que Maingueneau denomina "entrecomillado de unidades léxicas",64 y describe como "interferencias léxicas" 65 conlleva diversos efectos de sentido $^{66}$. En otro capítulo ha quedado dicho que los índices gráficos de discurso directo constituyen marcas de una representación discursiva que se interpreta como literal, aunque en realidad no siempre lo sea: la supuesta literalidad de la cita no es más que una "ilusión lingüística" ${ }^{67}$ Aun en casos de extrema similitud formal, resulta imposible reproducir el significado íntegro del texto, pues al situarlo en otro contexto, muchas veces tendencioso, se altera sin remedio su sentido original. ${ }^{68}$ Desde luego, esto se acentúa en casos, como los que ahora nos ocupan, donde un segmento del enunciado original se incorpora como constituyente de una secuencia distinta y formulada ad hoc.

\footnotetext{
${ }^{62}$ Voloshinov (1929) 1992: 178.

${ }^{63}$ También ha recibido el nombre de "discurso pseudo-directo" (Rivarola y Reisz de Rivarola 1984: 156).

${ }^{64}$ Maingueneau 1981: 108.

${ }^{65}$ Maingueneau 1976: 137.

${ }^{66} C f$. Récanati 2001: 680.

${ }^{67}$ Maingueneau 1981: 99; $c f$. Van Dijk (1980) 1990: 130, Ducrot (1984) 1986: 204, Reyes 1993: 24, Méndez García de Paredes 2000: 154, entre otros.

${ }^{68}$ Cf. Van Dijk (1977) 1980: 274, Maingueneau 1981: 99, Récanati 2001: 681.
} 
Los índices gráficos usados para marcar estos "islotes textuales" ${ }^{\text {69 }}$ constituyen recursos extrañantes que suponen, en principio, un distanciamiento de Loc 1 con relación a Loc 2 y al enunciado secundario: entrañan, de acuerdo con la ScaPoLine, lazos semánticos de representación que marcan la noresponsabilidad de Loc 1. Este recurso permite a Loc 1 indicar su desacuerdo con el punto de vista que Loc 2 asume o bien señalar que las palabras reproducidas pertenecen a un registro lingüístico que Loc 1 considera impropio o, al menos, no ejemplar.

(11) Contralor dice que el Zar Anticorrupción fue ‘ligero’ [тро 18/01/10: $1-13]$

En el titular (11), puede advertirse que Loc 1 manifiesta una discordancia con respecto al uso que Loc 2 hace de cierta palabra para describir parte de una situación. En conformidad con el modelo propuesto por la ScaPoLine, la configuración polifónica del sentido de este enunciado puede representarse de la siguiente manera:

-Pdv1: [E1] CIERTo ('Contralor dice que el Zar Anticorrupción fue $X$ ')

-Pdv2: [E2] CIERTO $(X=$ 'ligero')

-Pdv3: [E3] INJUSTIFICADO (pdv2)

El ejemplo (11) encierra, por lo menos, tres pdv. El pdv1, independiente, comprende la información expresada en la estructura receptora en discurso indirecto marcado; en ella se introduce el elemento $X$ - evidentemente un adjetivo en función de atributo que califica al sintagma nominal el Zar Anticorrupción - como un constituyente extraño, articulador del efecto de sentido que ahora nos interesa. El pdv2 presenta como cierto el contenido que describe como 'ligero' al Zar Anticorrupción (es decir, su comportamiento); el elemento $X$ se define, pues, con la palabra ligero. Por último, el pdv3 juzga el pdv2 como injustificado.

${ }^{69}$ Nølke, Fløttum y Norén 2004: 77. 
Loc 1 se adhiere al pdv3, mientras que Loc 2, al pdv2. En otras palabras, el periodista consigue marcar una distancia en relación con una parte del enunciado originario, al señalarla como imprecisa. El sentido del titular se encamina a concluir, por tanto, que el comportamiento del Zar Anticorrupción no fue, en realidad, tan ligero. De esta manera, Loc 1 consigue representar y cuestionar, al mismo tiempo, determinadas palabras de Loc 2 dentro de una reformulación analítica, cuyos términos — lo hemos dicho ya- se atribuyen en principio a Loc 1. Es por ello que estos usos de las comillas, que algunos consideran inaceptables en los titulares periodísticos, ${ }^{70}$ son a menudo descritos como indicadores de una "naturaleza contenciosa". ${ }^{71}$

(12) a. Especial compromiso de Fox con los capitalinos [JOR 25/02/05: 5] b. Salmoneros "lamentan" no aprobación de ley [MER 21/01/10: B7]

Análisis muy similares pueden hacerse con los encabezados de la serie (12), que presentan estructuras receptoras de otras clases. Loc 1 pone en duda, en (12a), que realmente exista un "compromiso especial" de Fox con los capitalinos y, en (12b), que la actitud de los salmoneros fuese realmente de lamento. Sirvan estos ejemplos, además, para comprobar que la hibridación local no siempre supone un "discurso directo predeterminado", 72 pues el constituyente con marcas de literalidad puede situarse en posición inicial —(12a)—, medial — (12b)—o final — (11)—: son "citas estratégicas", 73 dice Richadson. Estos ejemplos también permiten constatar que el efecto de distanciamiento de las comillas no es muy diferente del de las letras cursivas, que, evidentemente, también "reducen intencionalmente su uso

\footnotetext{
${ }^{70}$ Pou Amérigo 2004: 255, por ejemplo.

${ }^{71}$ Richadson 2007: 102.

${ }^{72}$ Voloshinov (1929) 1992: 178.

${ }^{73}$ Richadson 2007: 102.
} 
concentrándose en torno a un elemento o una frase entera que resulta clave frente a las demás en cuanto a intención significativa". ${ }^{7}$

(13) Que Carlos está 'feliz'... [REF 24/02/05: 4E]

El encabezado (13) se enunció luego de que la reina Isabel II de Inglaterra anunció su decisión de no asistir a la boda civil del príncipe Carlos, su hijo, con la plebeya Camila Parker-Bowles. Hay una estructura receptora en discurso indirecto marcado con verbo subordinante elidido y declarante omitido; además, un adjetivo entrecomillado se incorpora, como atributo, en la oración subordinada. El sentido del texto puede describirse de la manera siguiente:

-Pdv1: [E1] CIERTo ('Carlos está $X$ ')

-Pdv2: [E2] CIERTO ( $X=$ 'feliz')

-Pdv3: [E3] INJUSTIFICADO (pdv2)

-Pdv4: [E4] INCIERTO (pdv3)

Como puede advertirse, la estructura polifónica del enunciado (13) es relativamente compleja. El pdv1, que es independiente, introduce el elemento $X$ como atributo de la entidad Carlos. El pdv2 juzga como cierto el contenido que define el elemento $X$ como feliz. Para E3, que introduce el pdv3, el pdv2 no se justifica; esto es, según dicho enunciador, el príncipe Carlos en realidad no está feliz. El pdv4, por último, señala como incierto el pdv3: para E4, no se tiene, a pesar de todo, la seguridad de que el príncipe Carlos no esté feliz. Así pues, Loc 1 asume el pdv4, y Loc 2, el pdv2 o bien el pdv3 (puesto que hay duda). Los puntos suspensivos parecen reforzar, en este caso, la manifestación de la inseguridad experimentada por Loc $1-\mathrm{y}$ E4 - con respecto al pdv3.

Las formas de hibridación local pueden entrañar, pues, un cambio de punto de vista $\mathrm{y}$, por tanto, un distanciamiento de Loc 1 con respecto a una parte del discurso de Loc 2: por medio de las marcas ortográficas, Loc 1 aísla dicho

\footnotetext{
${ }^{74}$ Verdín Díaz 1970: 70.
} 
segmento para excluirlo del pdv independiente que contiene la información expresada en la estructura receptora (pdv1 en los ejemplos analizados); se articulan entonces diversos mecanismos polifónicos que apuntan a la conclusión de que el contenido del segmento marcado es, por lo menos, dudoso. Naturalmente, esto comprende todos los casos de discurso bivocal de orientación múltiple, ${ }^{75}$ con ironía o sin ella. ${ }^{76}$

El distanciamiento de Loc 1, resultante de la adherencia a un punto de vista diferente del que asume Loc 2, puede deberse a directrices editoriales, que representan la ideología subyacente de la organización informativa, o bien, como afirma Gutiérrez Ordóñez, a responsabilidades legales. ${ }^{77}$ En cualquier caso, Loc 1 hace evidente su opinión al tiempo que se esconde, ficticiamente, tras su papel de "simple retransmisor". Este último es asumido, como se sabe, a causa de un interés por insuflar mayor carga de verosimilitud y credibilidad al texto periodístico. ${ }^{78}$

(14) Piden hablar "al tú por tú" con el Inali [JOR 23/02/05: 4a]

En algunos casos, como el del titular (14), la función demarcativa ${ }^{79}$ de los índices gráficos establece una distancia $-\mathrm{O}$ espacio intertextual— ${ }^{80}$ indicadora de un registro lingüístico considerado por Loc 1 impropio o no ejemplar, al menos para su uso en el discurso de los encabezados periodísticos. En este ejemplo, una estructura de discurso narrado con infinitivo objetivo incorpora, con marcas ortográficas de discurso directo, la locución adverbial al tú por tú, que, en el registro coloquial del español actual

\footnotetext{
${ }^{75}$ Cf. Bajtín (1963) 1986: 280-291.

${ }^{76}$ En los casos (11), (12a) y (12b), presentan, desde luego, sentidos irónicos con relación a los elementos señalados ortográficamente.

${ }^{77}$ Gutiérrez Ordóñez 1986: 36.

${ }^{78} C f$., entre otros, Gutiérrez Ordóñez 1986: 36, Romero Álvarez 2000: 104-105.

${ }^{79}$ Cf. Authier 1981.

${ }^{80}$ Cf. Fernández Lagunilla y Pendones 1993.
} 
de México, significa "en igualdad de fuerza, de capacidad o de actitud cuando se espera lo contrario". ${ }^{81}$ El distanciamiento que aquí se presenta responde menos a una discordancia de postura ideológica que a una diferenciación de estrato social: en términos de Coseriu, es posible decir que el motivo central de este tipo de hibridación es un interés de Loc 1 por distinguirse de Loc 2 en el eje diastrático. Se observa, pues, una búsqueda de prestigio social, que —es verdad - también revela, en última instancia, un punto de vista.

Este uso metalingüístico apunta a la construcción de un éthos de hablante culto o, por lo menos, identificable como perteneciente a un estrato sociocultural alto. En consecuencia, el enunciado presenta a Loc 2 como un hablante menos instruido, de usos lingüísticos tendientes a lo que podría llamarse "habla coloquial" o "vulgar". Conviene saber que Loc 2 es un importante dignatario de una comunidad indígena del sur de México, que Inali es la abreviatura del Instituto Nacional de Lenguas Indígenas y que los pueblos originarios de ese país, históricamente despreciados y estigmatizados, sobreviven por lo general en condiciones de marginación.

Todos estos condicionamientos pragmáticos se suman a otras motivaciones que animan, en el discurso de los titulares, al uso de este tipo de construcciones híbridas. Merece la pena mencionar, por ejemplo, la economía $^{82}$ que resulta de mencionar y usar al mismo tiempo las palabras de Loc 2, así como la flexibilidad ${ }^{83}$ derivada de las numerosas construcciones que posibilita la incorporación de una cita directa, en función de un constituyente cualquiera, dentro de alguna estructura receptora que comporte, ya sea con marcas o no, una alusión o representación discursiva no directa. ${ }^{84}$ Aunque presentan una baja frecuencia relativa de uso en los titulares,

${ }^{81}$ Lara Ramos et al. 2010: s. v. tú.

${ }^{82} C f$. Cappelen y Lepore 1997: 430.

${ }^{83}$ Cf. Bal (1978) 1990: 36, Waugh 1995: 149, Cappelen y Lepore 1997: 430, Fernández Lagunilla y Pendones 1997: 88.

${ }^{84}$ Méndez García de Paredes (1999: 122) menciona también otras motivaciones: las de crear el efecto de autenticidad, de testimonio, de aportar "color local", de dar cuenta de expresiones agudas e inteligentes y de producir la ficción de hacer dialogar a dos personajes. 
constituyen sin duda "un recurso propio de los textos periodísticos" ${ }^{\natural 5}$ que no parece conveniente censurar a priori — como hacen algunos-, ya que integran respuestas a concretas y sofisticadas necesidades de comunicación, características no solo del discurso informativo, sino de todos los "textos en los que importa la exactitud de la retransmisión, pero que no pueden, por la razón que sea, reproducir íntegramente los discursos ajenos". ${ }^{86}$

Recuérdese que cada género textual, en cuanto tradición discursiva, ${ }^{87}$ consagra sus propias formas de descripción del habla ajena al servicio de finalidades comunicativas concretas. El repudio de que a menudo son objeto las formas de hibridación local es explicable por no estar codificadas en las gramáticas, cuya base de descripción ha sido históricamente la lengua literaria, que en principio responde a otras necesidades de comunicación. Pero, como es obvio, esa no es razón para el desdeño. Prueba del sinsentido es que, aunque estén proscritas por algunos libros de estilo, su uso es persistente en prácticamente todos los diarios.

Pasemos a la hibridación global. Debo insistir en que todos los encabezados que recojo tienen, en cada caso, un solo origen informativo: no aluden más que a un acto o macro-acto de habla. Constituyen, además, textos integrados por una sola cláusula, lo que los convierte en unidades de pensamiento y de comunicación. Por estas razones, parece conveniente concebirlos y analizarlos de manera integral.

Dadas las dificultades que plantea la segmentación de un texto en enunciados —independientemente de lo que por ello se entienda-, la ScaPoLine ha introducido la noción de pasaje polifónico. Se trata de una unidad de segmentación textual que trasciende los límites del enunciado: ${ }^{88}$

\footnotetext{
${ }^{85}$ Maldonado 1999: 3553.

${ }^{86}$ Reyes 1984: 81; $c f$. Reyes 1993: 8.

${ }^{87}$ Kabatek 2005.

${ }^{88} C f$. Nølke, Fløttum y Norén 2004: 25.
} 
"Un número $\mathrm{x}$ de enunciados conforman un pasaje polifónico $\mathrm{y}$, a su vez, un número $\mathrm{x}$ de pasajes polifónicos conforman un texto". ${ }^{89}$ Las fronteras de un pasaje polifónico no son otras sino las de los distintos grupos de relaciones polifónicas que integran el sentido del texto. Dada la naturaleza misma del discurso de los titulares, nuestros casos no ofrecen al respecto mayores dificultades: los encabezados son textos constituidos, invariablemente, por un solo pasaje polifónico.

(15) Desmiente Diego Fernández a Ebrard; no tiene vergüenza [LAP 26/02/05: 2]

En el ejemplo (15), se yuxtaponen un segmento en discurso narrado y otro en discurso indirecto no marcado. La naturaleza no marcada de la segunda oración permite, en principio, dos interpretaciones: que el sujeto desvergonzado sea Diego Fernández o bien Marcelo Ebrard. Sin embargo, como he dicho ya, los titulares aluden siempre a un mismo acto o macro-acto de habla, de modo que, dado el origen explícito en el segmento inicial, debe entenderse que el sujeto carente de vergüenza es Marcelo Ebrard y no Diego Fernández. En el primer segmento, Loc 1 (el periodista) alude a la enunciación de un Loc 2 (Diego Fernández), que, según se deduce, ha aludido en otro momento a la de un Loc 3 (Marcelo Ebrard). Podemos caracterizar así las estructuras polifónicas del pasaje:

(i)

Pdv1: [E1] CIERTO (' $X$ ')

Pdv2: [X] CIERTO ('Ebrard dice la verdad')

Pdv3: [E2] INJUSTIFICADO (pdv2)

(ii)

Pdv4: [X] CIERTO ('Ebrard tiene vergüenza')

Pdv5: [E2] INJUSTIFICADO (pdv4)

Se desconoce el contenido proposicional del pdv1, cuyo origen es E1, enunciador con el que se identifica Loc 3. Si entendemos el verbo desmentir

${ }^{89}$ Puig 2004: 400. 
en su acepción de 'decir a alguien que miente', podemos señalar que E2 mantiene un lazo de no-responsabilidad semántico-lógico-refutativo ${ }^{90}$ en relación con el pdv2, que califica el pdv1 como verdadero; es decir, el enunciador muestra el carácter inadmisible del pdv y, obviamente, no se responsabiliza de él. E3 también refuta el pdv4.

Loc 1 y Loc 2 se identifican con E2 en el segmento inicial y, en el final, con E3: asumen, en consecuencia, los pdv 3 y 5 . Esto se debe al verbo de habla en el segmento en discurso narrado, pues supone que, efectivamente, alguien ha mentido; en la segunda parte, ello se explica por la naturaleza no marcada del fragmento. De hecho, el sentido del encabezado parece apuntar a que el pdv5 es la conclusión del pdv3: Ebrard no dice la verdad; por tanto, no tiene vergüenza (debido a la existencia de un topos que identifica decir la verdad con tener vergüenza). De este modo, Loc 1 se adhiere al punto de vista asumido por Loc 2: el periodista evidencia, pues, su coincidencia ideológica con la fuente informativa, es decir, Diego Fernández.

Narratológicamente, la hibridación global del titular (15) comporta una restricción del foco narrativo. También conocida como perspectiva, la focalización se encarga de mostrar el grado de restricción a que se somete la información narrativa: el narrador solo enuncia la información diegética que se halla al alcance de un determinado campo de conciencia, que puede ser la suya o no. El sujeto que percibe se conoce como focalizador: "El sujeto de la focalización, el focalizador, constituye el punto desde el que se contemplan los elementos". 91 El foco narrativo del ejemplo, externo a Loc 2 en el segmento en discurso narrado, se desplaza al campo de conciencia de este en el segmento en discurso indirecto no marcado: la información diegética, que comienza narrándose desde la perspectiva de Loc 1, acaba siendo referida desde el foco de Loc 2. Este cambio de perspectiva, que está acompañado por

${ }_{91}^{90} C f$. Nølke, Fløttum y Norén 2004.

${ }^{91}$ Bal (1978) 1990: 108; cf., entre muchos otros, Genette (1972) 1989: 244-246 y (1993) 1998: 51, Tacca 1978: 72, Grupo $\mu$ (1982) 1987: 275. 
un aumento en los atributos miméticos del discurso, acompaña la fusión de puntos de vista del pasaje polifónico. 


\section{AnÁlisis COMPARATIVO}

En este capítulo examinaré las distintas variedades del discurso ajeno a partir, por un lado, de las relaciones de similitud o desemejanza que estas contraen entre sí y, por otro, de las variaciones en las frecuencias de uso que presentan los diarios considerados. Identifico, en cuanto a los aspectos cuantitativos, una tendencia general y dos comportamientos específicos que describen la distribución de las formas del discurso ajeno en el corpus e incluso revelan actitudes que, hasta cierto punto, condicionan el grado de incidencia de las modalidades estudiadas. En cuanto a los aspectos cualitativos, se describen de manera general algunas circunstancias y propiedades de índole semánticopragmático-discursiva que también motivan, parcialmente, el uso de las distintas modalidades del discurso ajeno en los titulares periodísticos, bien entendido que la configuración lingüística de los titulares es el resultado de un proceso muy complejo, multicausal, que no debe ser simplificado abusivamente.

\subsection{Aspectos cuantitativos}

En el mundo hispánico existe, evidentemente, una clara tendencia a formular en discurso indirecto los titulares periodísticos que describen un acto discursivo ajeno. Todos los periódicos de la muestra cuantificada sitúan en segundo lugar de preferencia al discurso narrado y, en tercero, al discurso directo. Las formas mixtas son minoritarias en todos los diarios.

De acuerdo con mis materiales, el discurso indirecto registra una incidencia general del 61,2\% (2256/3689). La frecuencia de uso del discurso narrado es del 23,6\% (872/3689); del 12\% (443/3689) es la del discurso directo, mientras 
que la de las formas mixtas alcanza apenas el 3,2\% (118/3689). En el siguiente gráfico están representadas dichas proporciones:

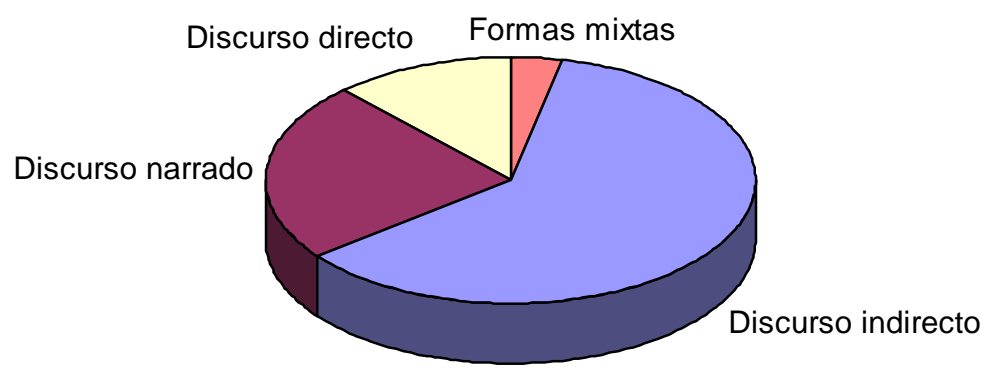

\section{Diagrama 1. Proporciones generales de las variedades del discurso ajeno}

Naturalmente, la tendencia general discurso indirecto > discurso narrado > discurso directo > formas mixtas presenta cierta variación que revela comportamientos específicos de los diarios considerados:

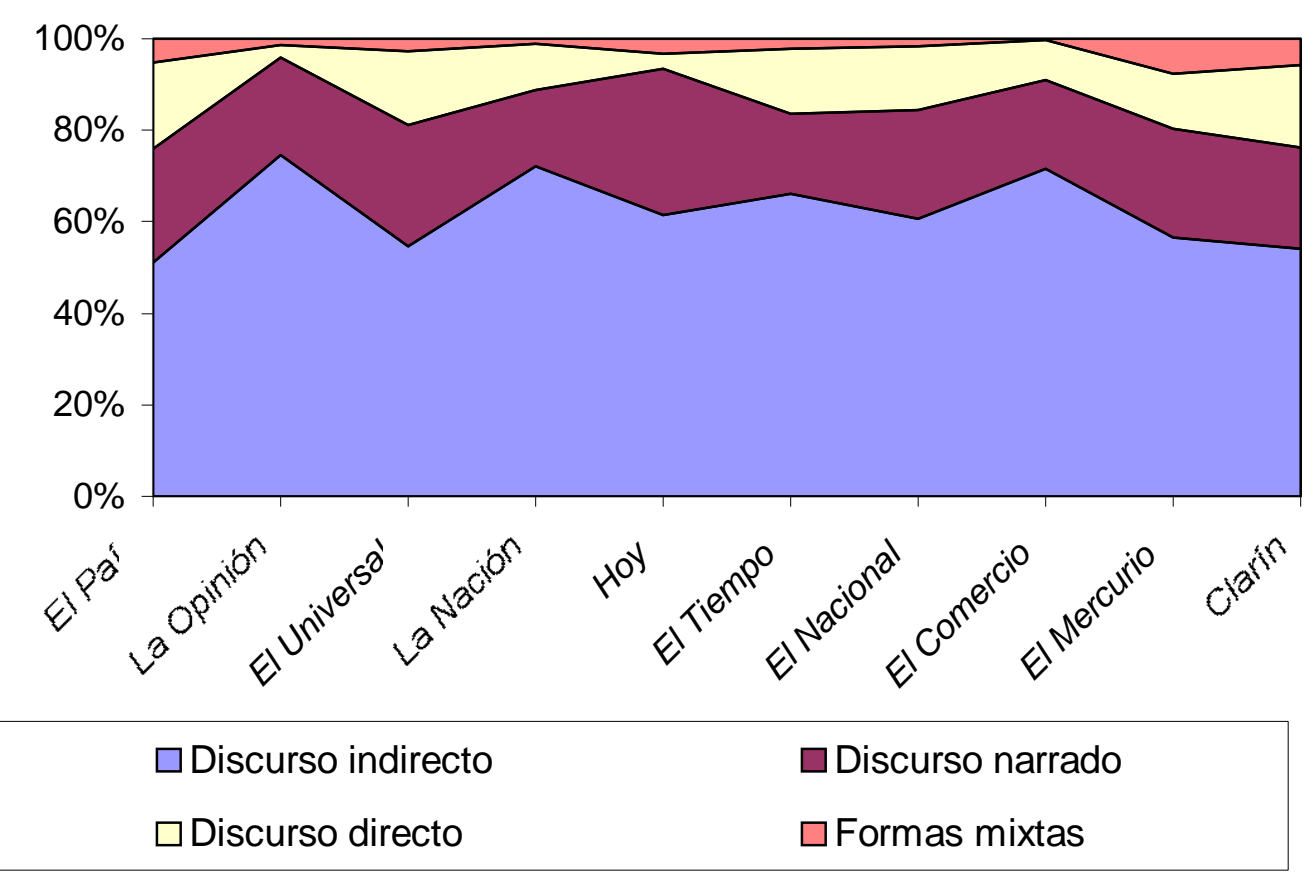

Diagrama 2. Distribución general de las variedades del discurso ajeno 


\begin{tabular}{|c|c|c|c|c|}
\hline & $\begin{array}{l}\text { Discurso } \\
\text { Directo }\end{array}$ & $\begin{array}{l}\text { Discurso } \\
\text { indirecto }\end{array}$ & $\begin{array}{l}\text { Discurso } \\
\text { narrado }\end{array}$ & $\begin{array}{l}\text { Formas } \\
\text { mixtas }\end{array}$ \\
\hline $\begin{array}{l}\text { El País } \\
\text { (Madrid) }\end{array}$ & $\begin{array}{l}19,0 \% \\
(48 / 253)\end{array}$ & $\begin{array}{l}51,0 \% \\
(129 / 253)\end{array}$ & $24,9 \%$ & $(13 / 253)$ \\
\hline $\begin{array}{l}\text { La Opinión } \\
\text { (Los Ángeles) }\end{array}$ & $(4 / 149)$ & $\begin{array}{l}74,5 \% \\
(111 / 149)\end{array}$ & $21,5 \%$ & $(2 / 149)$ \\
\hline $\begin{array}{l}\text { El Universal } \\
\text { (México) }\end{array}$ & $\begin{array}{l}16,0 \% \\
(101 / 630)\end{array}$ & $\begin{array}{r}54,8 \% \\
\quad(345 / 630)\end{array}$ & $\begin{array}{l}26,3 \% \\
\quad(166 / 630)\end{array}$ & $(18 / 630)$ \\
\hline $\begin{array}{l}\text { La Nación } \\
\text { (San José de } \\
\text { Costa Rica) }\end{array}$ & $10,3 \%$ & $\begin{array}{l}72,1 \% \\
(217 / 301)\end{array}$ & $16,6 \%$ & $(3 / 301)$ \\
\hline $\begin{array}{l}\text { Hoy } \\
\text { (Santo } \\
\text { Domingo) }\end{array}$ & $(18 / 531)$ & $\begin{array}{l}61,6 \% \\
(327 / 531)\end{array}$ & $\begin{array}{l}31,8 \% \\
\quad(169 / 531)\end{array}$ & $(17 / 531)$ \\
\hline $\begin{array}{l}\text { El Tiempo } \\
\text { (Bogotá) }\end{array}$ & $\begin{array}{r}14,3 \% \\
(41 / 286) \\
\end{array}$ & $\begin{array}{r}66,1 \% \\
\quad(189 / 286)\end{array}$ & $\begin{array}{l}17,5 \% \\
\quad(50 / 286)\end{array}$ & $(6 / 286)$ \\
\hline $\begin{array}{l}\text { El Nacional } \\
\text { (Caracas) }\end{array}$ & $14,0 \%$ & $\begin{array}{l}60,8 \% \\
\quad(226 / 372)\end{array}$ & $\begin{array}{l}23,7 \% \\
\quad(88 / 372)\end{array}$ & $(6 / 372)$ \\
\hline $\begin{array}{l}\text { El Comercio } \\
\text { (Lima) }\end{array}$ & $(35 / 400)$ & $\begin{array}{l}71,5 \% \\
\quad(286 / 400)\end{array}$ & $\begin{array}{r}19,5 \% \\
\quad(78 / 400)\end{array}$ & $(1 / 400)$ \\
\hline $\begin{array}{l}\text { El Mercurio } \\
\text { (Santiago de } \\
\text { Chile) }\end{array}$ & $12.2 \%$ & $\begin{array}{l}56,7 \% \\
(247 / 436)\end{array}$ & $\begin{array}{l}23,6 \% \\
(103 / 436)\end{array}$ & $(33 / 436)$ \\
\hline $\begin{array}{l}\text { Clarín } \\
\text { (Buenos Aires) }\end{array}$ & $\begin{array}{r}18,1 \% \\
(60 / 331) \\
\end{array}$ & $\begin{array}{r}54,1 \% \\
(179 / 331)\end{array}$ & $\begin{array}{r}22,1 \% \\
(73 / 331)\end{array}$ & $(19 / 331)$ \\
\hline
\end{tabular}

Puede apreciarse que esta tendencia general, que apunta hacia el uso mayoritario del discurso indirecto y minoritario de las formas mixtas, se encuentra muy acentuada en los diarios El Comercio, La Opinión y La Nación. En todos ellos, el uso del discurso indirecto sobrepasa el $70 \%$ y el de las formas mixtas ni siquiera alcanza el 1,5\% (en ningún diario la frecuencia relativa de uso del discurso indirecto es inferior al 50\% ni superior al $8 \%$ la de las formas mixtas).

A primera vista, destaca asimismo la elevada incidencia de discurso narrado en el periódico Hoy, pues su empleo excede el 30\%, en contraste con las demás publicaciones, que registran frecuencias de uso de discurso narrado que oscilan entre el $15 \%$ y el $25 \%$, aproximadamente. También es notoria, hasta cierto punto, la relativamente alta asiduidad de formas mixtas en los diarios El Mercurio, Clarín y El País, ya que en ellos tales formas discursivas 
superan el $5 \%$ y, en ninguno de los otros diarios, su uso alcanza siquiera el $4 \%$.

A pesar de ello, y como veremos en seguida, parece que la diferencia clave tiene que ver con las frecuencias relativas de uso del discurso directo. En atención a ello, se identifican dos comportamientos diferentes en la codificación linguiística de los titulares periodísticos que describen un acto discursivo ajeno:

Comportamiento 1: discurso directo $>10 \%$.

Comportamiento 2: discurso directo $\leq 10 \%$.

El comportamiento 1, caracterizado por una preferencia por el discurso directo mayor al 10\%, es adoptado por los periódicos El País, Clarín, El Universal, El Tiempo, El Nacional y El Mercurio. Por el contrario, el comportamiento 2 , que presenta una incidencia de discurso directo menor o igual a 10\%, es exhibido por los diarios La Opinión, Hoy, El Comercio y La Nación.

Pertenecen al grupo del comportamiento 2 todos los diarios que presentan acentuada la tendencia general. En efecto, El Comercio, La Opinión y La Nación registran muy elevadas incidencias de discurso indirecto y bajas frecuencias de uso tanto de formas mixtas como de discurso directo. Esto se debe, claro está, a que las formas mixtas son, mayoritariamente, estructuras que combinan discurso directo con otras modalidades del discurso ajeno. No es extraño, luego entonces, que los diarios que tienden a restringir el empleo del discurso directo en sus titulares publiquen también pocos encabezados híbridos. Aunque con ciertas reservas que describiré más adelante, puede decirse del periódico Hoy, perteneciente al grupo del comportamiento 2, que también polariza la tendencia general, pues en él la incidencia de discurso indirecto es mayor a la media y menor a ella la de formas mixtas. 
El comportamiento 2 -fuertemente asociado, como acabamos de ver, con la polarización de la tendencia general — parece estar parcialmente motivado por un aparente proceso de estigmatización del discurso directo, cuya existencia en el gremio periodístico revelan algunos manuales de redacción periodística. ${ }^{1}$ Gómez Mompart ${ }^{2}$ y Rojas Espinosa, ${ }^{3}$ por ejemplo, desaconsejan el uso de las comillas en los encabezados y Bastenier incluso las llama "letales enemigos"4 del periodista. Por consiguiente, y puesto que en ningún caso se expresan reservas, queda claro que este repudio no excluye el uso básico de estos signos de puntuación, que es, como bien se sabe, el de servir de marca de discurso directo. ${ }^{5}$ Esta situación impulsa, obviamente, el aumento de la asiduidad de los discursos narrado e indirecto, con lo que encuentran explicación frecuencias de uso extremas como la de Hoy con respecto al discurso narrado ${ }^{6}$ y las de La Opinión, El Comercio y La Nación en lo concerniente al discurso indirecto (la búsqueda de credibilidad o verosimilitud fomenta también, como ya se ha dicho, el uso de discurso directo y de formas mixtas que lo incorporan). ${ }^{7}$

No puede decirse que esa estigmatización sea algo muy generalizado, tal como demuestra el grupo que asume el comportamiento 1. En algunos diarios, como El País y Clarín, la incidencia de discurso directo es de casi la quinta parte del total de titulares que describen un acto discursivo ajeno.

\footnotetext{
${ }^{1}$ No siempre con una argumentación explícita. Tras esta actitud parecen hallarse, por un lado, la intención de evitar la sobreabundancia de citas ( $c f$. Bastenier 2001: 69-70), que en el gremio periodístico de algunos países recibe el peyorativo nombre de "declaracionitis" ( $c f$. Lichfield 2000: 55); por otro, la consabida pretensión de objetividad, habida cuenta de la expresión de un punto de vista discordante que entraña la connotación autonímica ( $c f$. Pou Amérigo 2004: 255), y, por último, el ánimo de no caer en hábitos propios de la prensa popular, que acude en sus titulares al discurso directo con notable asiduidad a causa de las propiedades histriónicas de esta variedad del discurso ajeno ( $c f$. Wierzbicka 1974: 272, Van Dijk [1980] 1990: 130).

${ }^{2}$ Gómez Mompart 1982: 119.

${ }^{3}$ Rojas Espinosa 2003: 104.

${ }^{4}$ Bastenier 2001: 69. Cf. Grijelmo 2003: 49.

${ }^{5}$ Por ejemplo, RAE y AALE 2010b: cap. III, §3.4.8.

${ }^{6}$ Retomaré este caso más adelante.

7 Cf. Van Dijk (1980) 1990: 130, Gutiérrez Ordóñez 1986: 36, Romero Álvarez 2000, Benavent Payá 2003: 18, López Pan 2004: 204.
} 
Evidentemente, quienes redactan o corrigen los titulares en esos periódicos están menos sensibilizados que los del grupo de diarios que asumen el comportamiento 2. Por cuanto las formas mixtas se vinculan claramente con el discurso directo, no es extraño que las publicaciones que exhiben el comportamiento 1 ostenten también las más altas incidencias de uso de configuraciones híbridas, a pesar del repudio de ciertos gramáticos y de las proscripciones de algunos libros de estilo: obsérvense, por ejemplo, las extremas frecuencias de uso de formas mixtas en El Mercurio, Clarín y El País (en realidad, en ningún caso de este grupo se registran incidencias inferiores al 1,5\%). Como es lógico, esta situación impulsa a la baja la proporción de uso del discurso indirecto (en El País, Clarín, El Universal, El Mercurio y El Nacional) y de discurso narrado (en El Tiempo).

El uso de discurso narrado oscila en la mayoría de los diarios entre el $20 \%$ y el $25 \%$. Las publicaciones que escapan de ello no parecen hacerlo sino como consecuencia, como ya hemos adelantado, de alguno de los dos comportamientos señalados. Es evidente que, en lo concerniente a Hoy, a ello parece sumarse una actitud más favorable hacia el discurso narrado que en los demás periódicos, sin que por ello se aleje de la tendencia general. En la venidera sección sobre discurso narrado, señalaré — no sin antes efectuar las comparaciones internas correspondientes a los discursos directo e indirectolos cuatro sub-comportamientos que se observan con respecto a las frecuencias relativas de las formas narradas (los cuales, veremos, resultan de los grados de asunción de la tendencia general y de si el periódico adopta el comportamiento 1 o 2 ).

Una deducción obvia de la tendencia general es que en todos los periódicos, incluidos los del comportamiento 1, la frecuencia de formas no directas (es decir, la suma de discurso indirecto y discurso narrado) es mayoritaria. En todos los diarios supera el 75\%. Desde luego, los valores máximos aparecen en las publicaciones que asumen el comportamiento 2, con La Opinión y Hoy 
a la cabeza (96\% y 93,4\%, respectivamente); los mínimos se observan en los diarios que exhiben el comportamiento 1 (El País y Clarín presentan las incidencias más bajas: $75,6 \%$ y 76,2\%, respectivamente).

Antes de describir los contrastes que se observan dentro de cada modalidad del discurso ajeno, debo señalar las dimensiones de las carencias que comportan las clasificaciones tradicionales. Si por clasificación tradicional entendemos la oposición gramatical que suele describirse entre lo que aquí llamamos discursos directo e indirecto marcados, queda evidenciado un sesgo insoslayable. Sabemos que, desde hace siglos, la tradición gramatical por lo general solo ha concebido por discurso indirecto la estructura compuesta por verbo de habla y conjunción subordinante explícitos que introducen una expresión ajena reformulada $\mathrm{y}$, por discurso directo, segmentos de transcripción literal introducidos normalmente por una oración subordinante con verbo de habla explícito y separados entonativa o gráficamente de ella. ${ }^{8}$ Sin embargo, aun concediendo la inclusión, en ese grupo, del discurso directo no marcado, las formas mixtas y todas las demás variedades del discurso indirecto marcado (estructuras elípticas, con potencial citativo y con la preposición para), todo ello conseguiría abarcar apenas el 21\% (776/3689) de nuestros materiales. Esto significa que tales clasificaciones son incapaces de dar cuenta de por lo menos el 79\% (2913/3689) de los titulares que describen un acto discursivo ajeno; y es muy probable que el sesgo con respecto al habla cotidiana sea parecido.

\footnotetext{
${ }^{8}$ Descontado, claro está, el llamado "estilo indirecto libre", sobre el cual no hay consenso por ser una categoría con fronteras muy borrosas (ambivalentes o contradictorias, según los autores, corrientes o tradiciones que se consideren). Para la discusión al respecto, véanse los capítulos sobre los discursos directo e indirecto.
} 

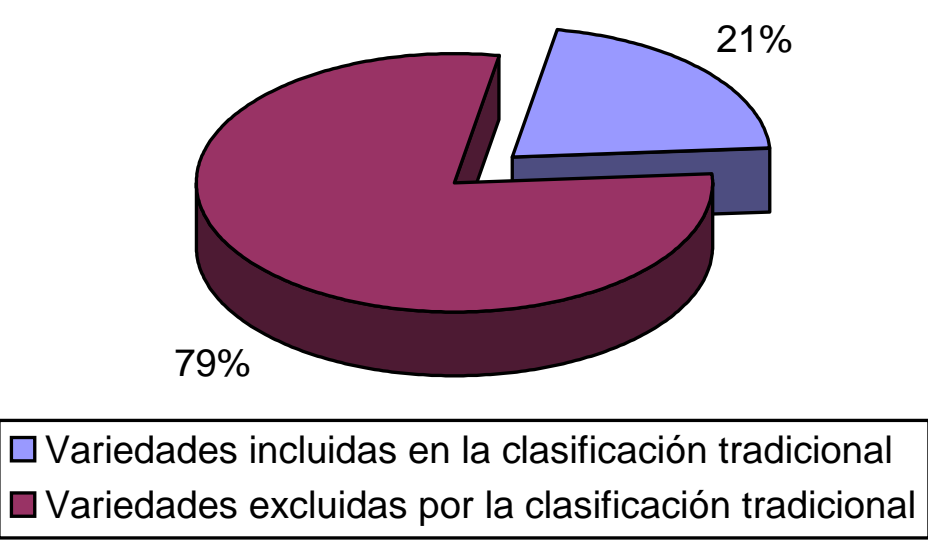

\section{Diagrama 3. Proporciones de las variedades del discurso ajeno según su inclusión o no en la clasificación tradicional}

En este diagrama se representan las proporciones de casos previstos y no previstos por esa clasificación del discurso ajeno. Las variedades excluidas son todas las formas del discurso narrado y del indirecto no marcado. Las incluidas son todos los testimonios de discursos directo, discurso indirecto marcado y formas mixtas, aunque es cierto que algunas de esas estructuras en realidad tampoco suelen ser consideradas (con todo, la proporción es muy minoritaria).

\subsubsection{Discurso directo}

A pesar de no corresponder más que al 12\% (443/3689) del corpus, el discurso directo constituye un factor decisivo en la composición de las frecuencias de uso de las variedades principales del discurso ajeno en cada periódico, según se asuma el comportamiento 1 o 2 , tal como acabamos de ver. Con las particularidades que han quedado descritas, los diarios El País, Clarín, El Universal, El Tiempo, El Nacional y El Mercurio presentan incidencias de discurso directo más elevadas que La Opinión, Hoy, El Comercio y La Nación. De manera general, el rango de asiduidad va del 2,7\% en La Opinión al 19\% en El País. 
Como hemos dicho, el discurso directo presenta dos grupos de variedades: marcadas, que, con el 96\% (426/443) de los casos, son indiscutiblemente mayoritarias, y no marcadas, que representan el 4\% (17/443). De manera general, las marcas de discurso directo más abundantes son las exclusivamente gráficas, con el 58,2\% (248/426); después están los verbos de habla subordinantes, con el 25,8\% (110/426) y, por último, los casos de doble marca, con el $16 \%(68 / 426)$.

Los verbos de habla son, sin embargo, las marcas predominantes en $L a$ Opinión y, sobre todo, El Universal. Hoy presenta más casos de marcas dobles que de índices gráficos empleados como marcas únicas de discurso directo, y en El País y El Mercurio no se observan casos de verbo subordinante como marca única de retransmisión directa.

Ya inglesas (" "), simples (" ’) o angulares («»), las comillas son los únicos índices exclusivamente gráficos de discurso directo en el corpus cuantificado. Las inglesas son las más abundantes, con el 76,6\% de todos los casos de discurso directo marcado ortográficamente (190/248); el 23\% (57/248) corresponde a las simples y el 0,4\% (1/248) a las angulares.

Aunque se observa de manera sistemática en otras publicaciones, sobre todo peninsulares, es evidente que el uso de las comillas angulares está, al menos en los titulares periodísticos del mundo hispánico, en claro retroceso. La motivación principal es, probablemente, de índole económica, ${ }^{9}$ pues estas comillas ocupan un espacio mayor que las demás. Esto también explica el uso cada vez más frecuente de las comillas simples para indicar retransmisiones literales, a pesar de los señalamientos de autores como Pou Amérigo, para quien las comillas simples suelen emplearse en los encabezados más bien con

\footnotetext{
${ }^{9}$ Así lo explicita el libro de estilo de El Mundo: "En los titulares, y por razones de utilización del espacio, se admitirá el empleo de comillas simples (") o dobles ("') en vez de las comillas españolas o romanas («»)" (El Mundo 1996: 76).
} 
la finalidad de "recoger un apodo, el nombre de un caso judicial o periodístico, una expresión no aceptada o el título de un libro o disco". ${ }^{10}$

Las alternancias en el uso de comillas como marcas de discurso directo que presentan los diarios La Nación y El Nacional -el primero entre inglesas y simples y el segundo entre angulares e inglesas - obedecen, a fin de cuentas, a la misma motivación económica, pues en ambos casos se observa una marcada preferencia por el signo tipográficamente más pequeño (comillas simples en La Nación e inglesas en El Nacional). Utilizan solamente comillas inglesas Clarín, El Comercio, El Mercurio, El País, El Universal y Hoy. En cambio, El Tiempo y La Opinión no emplean más que las simples. Las comillas angulares o latinas, las que ocupan un espacio mayor en las planas, no son empleadas por ningún periódico de la muestra cuantificada de manera exclusiva.

Si bien en términos generales la mayoría de los titulares en discurso directo marcado presenta solamente marcas ortográficas, las frecuencias relativas de uso son muy heterogéneas, pues van del 7\% (7/94) en el diario mexicano $E l$ Universal al 90\% (43/48) en el periódico español El País. Amén de El Universal, ostentan incidencias notablemente inferiores a la media del 58,2\% —menores que el 40\% - La Opinión y Hoy. Además de en El País, utilizan marcas gráficas en proporciones significativamente superiores a la media - mayores que el 80\% - El Comercio, Clarín, La Nación y El Tiempo. Los valores de El Nacional y El Mercurio son muy similares a la media. Se deduce, por consiguiente, que en los periódicos de América del Norte y del Caribe insular se tienden a preferir otras formas de marcar la retransmisión directa de las palabras ajenas, como detallaremos después.

Son menos frecuentes, en términos absolutos, los encabezados en discurso directo donde un verbo subordinante, expreso o elíptico, funciona como

\footnotetext{
${ }^{10}$ Pou Amérigo 2004: 255.
} 
marca única de retransmisión supuestamente literal. La mayoría de estos casos $-83,6 \%(92 / 110)$ — son testimonios de verbo de habla elidido y fueron publicados todos los diarios del corpus cuantificado, salvo El País y El Mercurio (volveré a ello más adelante). Los titulares con verbo expreso son bastante más infrecuentes —16,4\% (18/110)—y se concentran únicamente en los diarios El Universal, El Tiempo y Hoy. Debido a que no he rastreado titulares con verbo de habla subordinante como marca única de discurso directo en la prensa española, ni siquiera en los sucesivos corpus piloto, ${ }^{11}$ puede decirse que se trata de un fenómeno propio de la prensa hispanoamericana, más frecuente hacia la zona más septentrional.

Los casos de doble marca — verbo subordinante e índices gráficos- son minoritarios en términos absolutos, pero se presentan en los diez periódicos. En el 94,1\% (64/68) de los casos, la marca ortográfica afecta a todo el segmento $2 ;^{12}$ en el resto -todos del mexicano El Universal-, el entrecomillado abarca solo algún constituyente de ese segmento. Habida cuenta de la naturaleza redundante de la marca doble y de la inexactitud de las citas directas en los textos periodísticos, parece claro que la finalidad que anima a este grupo de construcciones es la de enfatizar la supuesta literalidad del segmento 2 o algún constituyente de él. También deben tenerse en cuenta los posibles pruritos de corrección, pues, a diferencia de lo que sucede con las demás marcas, la fórmula VERBO DE HABLA + DOS PUNTOS + COMILLAS está codificada por casi todas las gramáticas y ortografías.

El orden de constituyentes que antepone la mención del declarante a la reproducción de la declaración, que hemos llamado S1-S2, es mayoritario - $89,1 \%$ (57/64) — entre los casos de doble marca, pero es minoritario -35,5\% (39/110) — entre los de verbo de habla como marca única. Aunque

\footnotetext{
${ }^{11}$ Aunque Hurtado (2009: 195-197) sí, pero admitiendo que se trata de un fenómeno mucho menos frecuente que en Hispanoamérica. Incluso asegura que podría considerarse un cliché de la prensa colombiana.

${ }^{12}$ Es decir, la expresión citada. El segmento 1 corresponde a la oración subordinante atribuible exclusivamente a Loc 1 (véase el capítulo sobre discurso directo).
} 
en los diversos periódicos del ámbito hispánico se presentan otras soluciones, las marcas ortográficas empleadas para indicar el cambio de nivel discursivo de la a veces llamada "cita directa bimembre"13 fueron siempre dos puntos cuando el orden es S1-S2 y coma o dos puntos cuando, independientemente de la presencia o ausencia de comillas, se presenta la secuencia inversa, aquí llamada S2-S1.

El orden S2-S1 es, pues, dominante —64,5\% (71/110) — entre los titulares en discurso directo sin comillas y con verbo subordinante (tanto expreso como elíptico). Los casos proceden, sin embargo, de solamente tres periódicos: el mexicano El Universal, el colombiano El Tiempo, el estadounidense La Opinión y el dominicano Hoy. A pesar de ello, y dado que se observan numerosos ejemplos con elipsis de verbo de habla en los tres primeros, queda refutado el no poco generalizado mito de que los titulares con verbo de habla elíptico y orden S2-S1 son un rasgo identificador de la prensa mexicana. ${ }^{14} \mathrm{~A}$ estos casos se suman los de disposición S2-S1 y doble marca, presentes en los mismos periódicos. Los siguientes son ejemplos nada anómalos de prensa no mexicana (proceden de Colombia y Estados Unidos):

\section{(1) a. Blanco no gana solo: Del Olmo [OPI 19/01/10: 3C] \\ b. No pienso aplazar elecciones: Presidente [TPO 19/01/10: 1-3] \\ c. MESSI ES SUPERIOR A CRISTIANO: MARADONA [OPI 22/01/10: 2C] \\ d. 'Por ahora, no hay más ayuda en especie': Cruz Roja [TPO 21/01/10: 1-5]}

Ausentes, eso sí, en los diarios peninsulares, construcciones como las anteriores — con las que "se pretende dar realce al decir del otro"_ ${ }^{15}$ han sido a menudo repudiadas. En opinión de algunos, este orden de constituyentes resulta "en muchos casos chocante" dificultar la comprensión, sino permitir interpretaciones equivocadas si se

\footnotetext{
${ }^{13}$ Escribano Hernández 2007: 68.

${ }^{14}$ Por ejemplo, Báez de Aguilar González 2002: 84-86, Rebollo Torío 2008: 169.

${ }^{15}$ Hurtado 2009: 195.

${ }^{16}$ Báez de Aguilar González 2002: 84.
} 
parte de la norma española". ${ }^{17}$ Si bien no es exclusivo de la prensa mexicana y no se observa en los periódicos españoles, tampoco puede decirse que sea un rasgo distintivo del periodismo americano, pues no registro casos en la prensa de países como Argentina, Chile, Perú y Costa Rica.

El orden S1-S2 en estructuras elípticas con marca redundante o sin ella es, en términos generales, menos frecuente que la disposición $\mathrm{S} 2-\mathrm{S} 1$, pero se encuentra mucho más generalizado. Se observa en todos los periódicos, aunque con particular insistencia en El País, El Mercurio, Clarín, La Nación, Hoy y El Nacional, que también presentan las mayores frecuencias de uso de discurso directo doblemente marcado. A pesar de ser menos frecuentes en $E l$ Universal y otros diarios mexicanos, es insostenible el planteamiento sugerido por Rebollo Torío en cuanto a que el orden S1-S2 tiende a ser anómalo en los encabezados de México, "según se puede comprobar fácilmente con una ojeada a la prensa de dicho país". ${ }^{18}$ Sin considerar más diarios mexicanos que El Universal —el mismo que ese autor-, un 26,9\% (18/67) de incidencia del orden S1-S2 en estructuras con verbo elidido como marca única de discurso directo (como las de la serie [2]) lo convierte, sí, en una construcción de uso minoritario, pero de ninguna manera en algo poco normal. Los que sí son relativamente infrecuentes en este diario y en los periódicos mexicanos en general son los encabezados con orden S1-S2 y doble marca en todo el segmento 2 .

(2) a. Santiago Creel: sí, voy por la Presidencia [UNI 23/01/10: A5]

b. Papa: Jesucristo también fue un emigrante [UNI 18/01/10: A26]

Debido a que la frecuencia de los titulares con orden S1-S2 se incrementa notablemente cuando hay comillas e incluso hay un periódico (El País) que solo acude a este orden cuando el segmento 2 se entrecomilla, es posible asegurar que existe una tendencia en la prensa hispánica a asignar un carácter

\footnotetext{
${ }^{17}$ Ibid:: 86.

${ }^{18}$ Rebollo Torío 2008: 169.
} 
formulaico al orden S1-S2 con las palabras de Loc 2 marcadas ortográficamente. Esto no se observa en los casos con el orden S2-S1, que suele aparecer sin comillas.

Aunque la disposición S2-S1 es más frecuente que S1-S2 en los periódicos de Estados Unidos (La Opinión), México (El Universal) y Colombia (El Tiempo), en cifras absolutas es ligeramente más frecuente el orden S1-S2. ${ }^{19}$ Las frecuencias se polarizan si se elimina el sesgo impuesto por el diario mexicano El Universal, que concentra por sí mismo la mayor cantidad de testimonios de discurso directo y que tiene, como hemos dicho, una clara predilección por el orden S2-S1: la proporción del S1-S2 aumenta hasta el $85,4 \%(76 / 89)$ en la suma de testimonios de discurso directo hipotáctico publicados en los diarios restantes, mientras que la de S2-S1 se contrae hasta el 14,6\% (13/89). Estos datos revelan la existencia de regiones en el continente americano que se alejan de la tendencia a preferir el orden S1-S2 y que algunos ejemplos de esas zonas son Estados Unidos, Colombia y, particularmente, México.

El periódico español El País y el chileno El Mercurio no presentan casos de discurso directo señalado por únicamente el verbo de habla debido a que no publican encabezados con retransmisiones literales marcadas sin comillas. Estos diarios son los únicos que se ajustan a las habituales recomendaciones ortográficas de siempre entrecomillar las palabras ajenas que se reproducen de manera literal. Como señalé en el capítulo sobre discurso directo, ambas publicaciones acaparan por esa razón la mayor parte de testimonios de discurso directo doblemente marcado (aunque, en cifras relativas, prefieran las comillas solas).

En lo concerniente a la preferencia general por determinadas marcas de discurso directo en cada diario, hemos dicho ya que los periódicos de

${ }^{19} 54 \%(95 / 176)$ de S1-S2 frente a $46 \%(81 / 176)$ de S2-S1. 
América del Norte y del Caribe insular tienden dan prioridad a formas distintas de las comillas solas, a diferencia de los diarios de Europa, América Central y América del Sur. En efecto, los diarios de España (El País), Costa Rica (La Nación), Colombia (El Tiempo), Venezuela (El Nacional), Perú (El Comercio), Chile (El Mercurio) y Argentina (Clarín) acuden a marcas exclusivamente ortográficas en proporciones que oscilan entre el 60\% ( $E l$ Mercurio) y el 90\% (El País). Las publicaciones de Estados Unidos (La Opinión) y México (El Universal) prefieren, en cambio, marcas exclusivamente sintácticas —es decir, verbos subordinantes expresos o elípticos- en la mayoría de sus encabezados en discurso directo marcado (50\% en La Opinión y $85 \%$ en El Universal). La mayor parte de los pocos titulares del diario dominicano (Hoy) corresponde, por último, a marcas dobles.

El periódico colombiano El Tiempo y, sobre todo, el mexicano El Universal son los que emplean mayor variedad de marcas distintas de discurso directo. Pocas formas innovadoras $-\mathrm{y}$, por consiguiente, menor variación- se observan en los demás diarios, particularmente en los de España (El País), Chile (El Mercurio) y, en menor medida, Argentina (Clarín), los cuales en este aspecto parecen conformar un solo grupo bastante apegado a las fórmulas tradicionalmente codificadas por las gramáticas y ortografías.

En su estudio sobre los titulares del periodismo digital, Hurtado denuncia lo que interpreta como "el aparente descuido que presentan los diarios hispanoamericanos en el uso de los signos de puntuación que acompañan al discurso directo, en especial, las comillas, lo que no favorece ni la claridad ni la credibilidad periodística". ${ }^{20}$ Al respecto, y al margen de que ya se ha demostrado que la literalidad de las citas entrecomilladas es más convencional

\footnotetext{
${ }^{20}$ Hurtado 2009: 201.
} 
que real también en el periodismo español, ${ }^{21}$ conviene recordar que, en el "sistema semiológico particular,"22 que conforma el discurso de los titulares, no son solamente las comillas los elementos asociados con el polo semántico de la supuesta retransmisión literal, ${ }^{23}$ sino también determinadas configuraciones gramaticales abstractas, puesto que la correspondencia irrenunciable entre forma y significado alcanza no solamente al signo, sino a cualquier tipo de estructura lingüística, ${ }^{24}$ sobre todo con su uso rutinario en aras de la satisfacción de necesidades comunicativas recurrentes. Es por ello que las comillas constituyen marcas redundantes en los contextos de discurso directo con oración subordinante que quedaron descritos en el capítulo correspondiente (además, hay que tener en cuenta que su escasez en determinados periódicos parece responder parcialmente a la estigmatización que ya hemos referido y a las fuertes necesidades de economía de este tipo de discurso). Es preciso desterrar, pues, la ingenua idea de que el discurso directo va siempre acompañado por comillas, aunque así parezca ser en la prensa de un par de lugares.

En cuanto al discurso directo no marcado, la escasez de testimonios - apenas el 4\% (17/441) del total— impide realizar comparaciones más o menos rigurosas. Solo puedo asegurar, de momento, que, restringiendo la descripción al corpus cuantificado, se identificaron casos únicamente en Clarín, El Comercio, El Mercurio, El Tiempo, El Universal y Hoy. Con fundamento en los datos del corpus piloto, es posible suponer que se presenta en periódicos de todo el mundo hispánico, en especial en los de corte popularsensacionalista o en las secciones poco relevantes desde el punto de vista

\footnotetext{
${ }^{21}$ Méndez García de Paredes 2000a. En realidad, el problema ni siquiera es exclusivo de la prensa hispánica (para una revisión del asunto en el periodismo estadounidense, $c f$. Fuller 1996: 139-142). La cuestión fue abordada detalladamente en nuestro capítulo sobre el discurso directo.

${ }^{22}$ Alarcos 1977: 130.

${ }^{23}$ La prensa española tampoco parece ser ajena a esto. Grijelmo (2003: 50), el redactor principal del libro de estilo de El País de Madrid, reconoce, por ejemplo, que el empleo de comillas en los titulares en discurso directo es algo que "no siempre ocurre".

${ }^{24}$ Fillmore 1982, Goldberg 1995, Kay 1997, entre otros.
} 
político-económico — como las de espectáculos y deportes-y que se trata, por tanto de un rasgo caracterizador de los titulares que Casasús llama "fantásticos" o "de efecto"25 (frente a los que denomina "fríos", propios de los diarios conocidos como informativo-interpretativos, que son el tipo de publicación que se tuvo en cuenta al conformar la muestra cuantificada en este trabajo).

\subsubsection{Discurso indirecto}

Ya hemos dicho que existe una tendencia general en el mundo hispánico a titular las noticias en discurso indirecto. Todos los periódicos de mis materiales acuden a esta forma de actualizar las palabras ajenas en proporciones que exceden el 50\% (la media es del 61,2\% [2256/3689]). Presentan las frecuencias más altas los diarios La Opinión, La Nación y El Comercio, con más del 70\%, y las más bajas, El País, El Universal, El Mercurio y Clarín, con incidencias que van del $51 \%$ al $57 \%$. Hoy, El Nacional y El Tiempo se sitúan en una posición intermedia.

El 90,5\% (2041/2256) está representado por el discurso indirecto no marcado, mientras que solo el 9,5\% (215/2256) corresponde a formas marcadas. El diagrama siguiente representa las proporciones de discurso indirecto marcado y no marcado en cada uno de los diez diarios de la muestra: ${ }^{26}$

\footnotetext{
${ }^{25}$ Casasús 1989: 59.

${ }^{26}$ He aquí la tabla correspondiente:
}

\begin{tabular}{|l|l|l|}
\hline & Indirecto marcado & Indirecto no marcado \\
\hline
\end{tabular} 


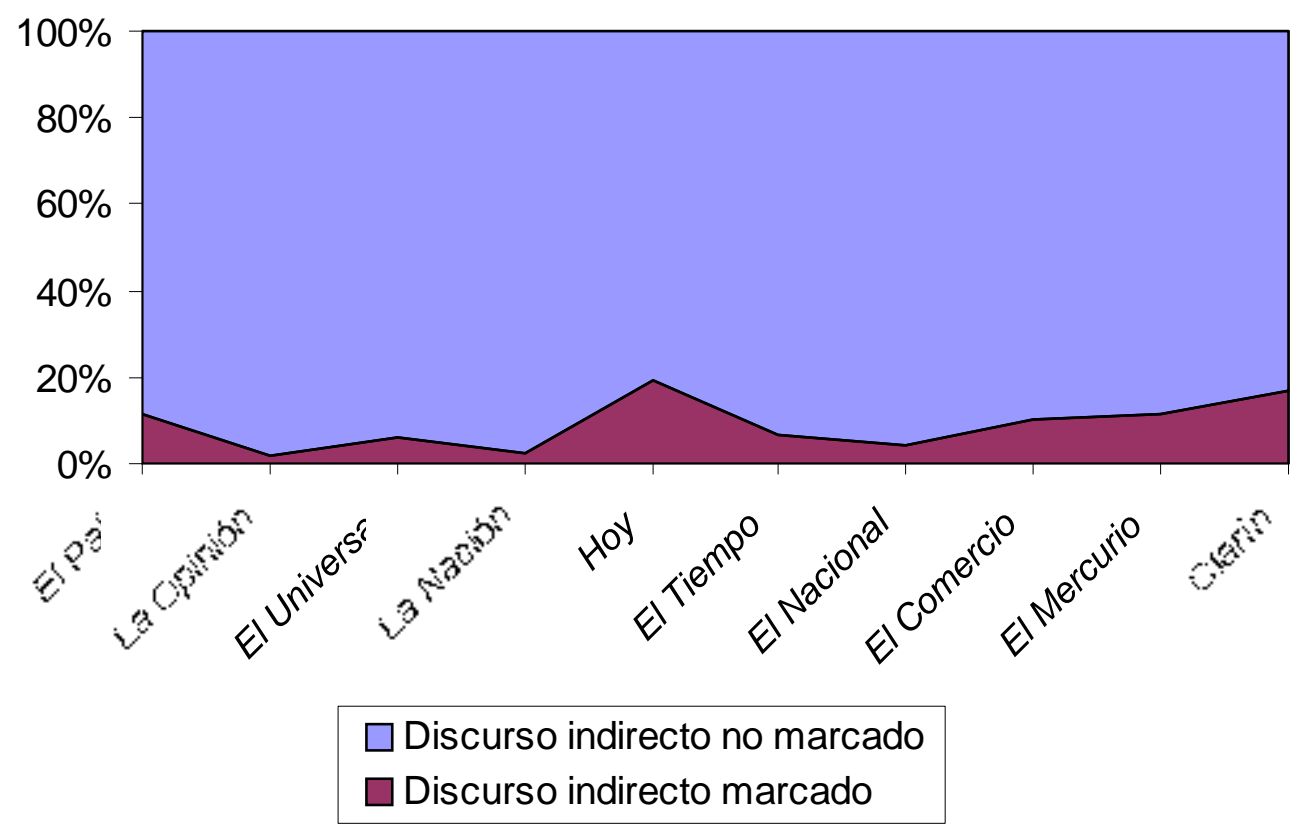

\section{Diagrama 4. Distribución de las variedades marcadas y no marcadas del discurso indirecto}

Destaca, a primera vista, que el discurso indirecto no marcado se emplea en proporciones muy cercanas al $100 \%$ en casi todos los diarios, particularmente en La Opinión y La Nación. El dominicano Hoy es el que menos acude a las formas no marcadas, con nada menos que el $80,7 \%$ de sus testimonios de discurso indirecto.

En realidad, de todas las variedades del discurso ajeno, las formas no marcadas de retransmisión analítica son, por sí solas, la más frecuente: representan el 55,3\% (2041/3689) de todo el corpus. La proporción es, desde

\begin{tabular}{|l|l|l|}
\hline El País & $11,6 \%(15 / 129)$ & $88,4 \%(114 / 129)$ \\
\hline La Opinión & $1,8 \%(2 / 111)$ & $98,2 \%(109 / 111)$ \\
\hline El Universal & $6,1 \%(21 / 345)$ & $93,9 \%(324 / 345)$ \\
\hline La Nación & $2,3 \%(5 / 217)$ & $97,7 \%(212 / 217)$ \\
\hline Hoy & $19,3 \%(63 / 327)$ & $80,7 \%(264 / 327)$ \\
\hline El Tiempo & $6,9 \%(13 / 189)$ & $93,1 \%(176 / 189)$ \\
\hline El Nacional & $4,0 \%(9 / 226)$ & $96,0 \%(217 / 226)$ \\
\hline El Comercio & $10,1 \%(29 / 286)$ & $89,9 \%(257 / 286)$ \\
\hline El Mercurio & $11,3 \%(28 / 247)$ & $88,7 \%(219 / 247)$ \\
\hline Clarín & $16,8 \%(30 / 179)$ & $83,2 \%(149 / 179)$ \\
\hline
\end{tabular}


luego, notablemente superior en La Nación y La Opinión, donde supera el $70 \%$. Por cuanto en ningún caso es inferior al $45 \%$ (Clarín), ${ }^{27}$ puede decirse, sin lugar a dudas, que constituye la solución preferida por los periodistas para aludir a actos discursivos ajenos, al menos en los encabezados. Como quedó dicho en el capítulo sobre discurso indirecto, es muy probable que las frecuencias de uso sean aún más elevadas, puesto que nada impide que las noticias sean reelaboraciones de textos ajenos no mencionados (para Rivadeneira Prada, ${ }^{28}$ eso es, de hecho, algo habitual).

A pesar de lo que podría suponerse a priori, bastante minoritario es el uso del discurso indirecto marcado en los titulares. En La Opinión y La Nación, la frecuencia es de aproximadamente el 2\% de los casos de retransmisión indirecta. Se observan incidencias ligeramente mayores en El Nacional, El Tiempo y El Universal (entre el 4\% y el 7\%). El País, El Comercio, El Mercurio y Clarín recurren a estas formas en proporciones que oscilan entre el $10 \%$ y el $17 \%$. Hoy es el periódico de la muestra contabilizada que más acude al discurso indirecto marcado, con poco más del $19 \%$ de sus encabezados.

Independientemente de lo anterior, casi todos los diarios exhiben claras preferencias por determinadas indicaciones textuales de reproducción analítica. La marca compuesta por verbo y conjunción explícitos presenta frecuencias de uso mayores o iguales al 50\% en El País, Clarín, El Nacional, El Universal y La Opinión (en este último diario no registro otras marcas). ${ }^{29}$ Lo mismo puede decirse de Hoy con respecto a la estructura con conjunción elidida $^{30}$ y de El Mercurio, La Nación y El Tiempo ${ }^{31}$ en relación con el

\footnotetext{
${ }^{27}$ La relación pormenorizada es la siguiente: El País, 45,1\% (114/253); La Opinión, 73,2\% (109/149); El Universal, 51,4\% (324/630); La Nación, 70,4\% (212/301); Hoy, 49,7\% (264/531); El Tiempo, 61,5\% (176/286); El Nacional; 58,3\% (217/372); El Comercio, 64,3\% (257/400); El Mercurio, 50,2\% (219/436); Clarín, 45\% (149/331).

${ }^{28}$ Rivadeneira Prada 2007: 99.

${ }^{29}$ Las frecuencias exactas: El País, 93,3\% (14/15); Clarín, 73,3\% (22/30); El Nacional, 88,9\% (8/9); El Universal, 66,7\% (14/21); La Opinión, 100\% (2/2).

${ }^{30} 69,8 \%(44 / 63)$.
} 
potencial citativo. El diario peruano El Comercio registra un equilibrio, con poco menos de la mitad de los casos, entre este último y el verbo y la conjunción explícitos. $^{32}$

Todos los periódicos recurren en sus titulares a la estructura con verbo y conjunción explícitos; la utilizaron en menos del $50 \%$ de los casos $\mathrm{Hoy}, \mathrm{El}$ Tiempo, La Nación, El Mercurio ${ }^{33}$ y, como acabamos de decir, El Comercio. A pesar de repudio de ciertos gramáticos y hasta de algunos libros de estilo, el potencial citativo fue empleado en todos los periódicos, salvo La Opinión; en menos de la mitad de los casos, eso sí, en El País, Clarín, El Nacional, Hoy, El Universal ${ }^{34}$ y, claro, El Comercio.

Solamente recopilé testimonios de conjunción elidida procedentes de los periódicos Hoy y El Universal. ${ }^{35}$ Ello parece deberse a que estas son las publicaciones del corpus cuantificado que ostentan mayor cantidad de omisiones de determinantes, preposiciones y conjunciones en sus encabezados.

La elipsis de verbo de habla fue registrada en Clarín, El Comercio, El Mercurio y El Universal. Si bien se presentó en bajísimas proporciones y solo en estas publicaciones, ${ }^{36}$ el corpus piloto permite descartar la idea de que sea algo inusual o privativo de tales periódicos. Todos los ejemplos contabilizados son testimonios con según.

${ }^{31}$ El Mercurio, 50\% (14/28); La Nación, 60\% (3/5); El Tiempo, 61,5\% (8/13).

32 48,3\% (14/29) en ambos casos.

${ }^{33}$ Hoy, 15,9\% (10/63); El Tiempo, 38,5\% (5/13); La Nación, 40\% (2/5); El Mercurio, 46,4\% (13/28).

${ }^{34}$ El País, 6,7\% (1/15); Clarín, 10\% (3/30); El Nacional 11,1\% (1/9); Hoy, 14,3\% (9/63); El Universal, $14,3 \%(3 / 21)$.

${ }^{35}$ Solamente un caso en El Universal, que corresponde al 4,8\% (1/21).

${ }^{36}$ Clarín, 3,3\% (1/30); El Comercio, 3,4\% (1/29); El Mercurio, 3,6\% (1/28); El Universal, $4,8 \%(1 / 21)$. 
Se publicaron en Clarín y El Universal los testimonios de discurso indirecto introducido por la preposición para que fueron sometidos a cuantificación. ${ }^{37}$ Es posible decir, sin embargo, que se no rastrean con excesivas dificultades en otras publicaciones. Infrecuentes en todo caso, los titulares de este tipo siempre presentan en posición inicial la preposición para, a diferencia de los encabezados con según, que invariablemente registran esta conjunción después de las palabras ajenas reformuladas. ${ }^{38}$ Parece existir, luego entonces, una especialización de uso: para en los casos de S1-S2 y según en los de S2S1.

La mayor variedad de marcas fue observada, nuevamente, en el mexicano $E l$ Universal: ningún otro diario publicó, en los días considerados para la cuantificación, titulares con las cinco maneras de indicar la existencia de una retransmisión indirecta de palabras ajenas. El estadounidense La Opinión registró, por el contrario, la menor cantidad de ellas, pero también es cierto que también este rotativo ostenta la más baja incidencia de discurso indirecto marcado, tanto en número absoluto de testimonios como en frecuencias relativas de uso.

Indiscutiblemente mayoritario en los encabezados del mundo hispánico, el discurso indirecto no marcado adquiere diversas configuraciones sintácticas, ninguna de ellas privativa de este tipo de metarrepresentación, ${ }^{39}$ que entraña normalmente una asunción del punto de vista de Loc 2 por parte de Loc 1. Una manera de analizarlo es atendiendo a la mención o no del origen de las palabras ajenas en el titular o el texto que encabeza. Loc 2 está representado en el texto en el 29,5\% (602/2041) de los casos; no lo está en el texto, pero sí en el contexto — es decir, en la nota informativa- en el 66,5\% (1358/2041), y no lo está ni en el texto ni en el contexto en el 4\% (81/2041) restante.

\footnotetext{
${ }^{37}$ Clarín, 13,3\% (4/30); El Universal 9,5\% (2/21).

38 En su manual de titulación periodística, López Hidalgo (2009: 117) afirma, sin argumentos explícitos de por medio, que "sería incorrecta" en un encabezado la construcción que sitúa en posición inicial la partícula según.

${ }^{39} C f$. Noh 2000.
} 
Los titulares en discurso indirecto no marcado que sí aluden explícitamente a Loc 2 se observan en proporciones notoriamente superiores a la media del 29,5\% en El País, El Universal y Hoy. En un $40 \%$ de sus encabezados de este tipo, los tres periódicos exhiben a Loc 2 como participante en el contenido que vehicula la representación analítica no marcada de su propio discurso. Las frecuencias relativas de uso en los demás diarios varían del $11 \%$ al $28 \%$. $^{40}$ Normalmente, Loc 2 es conceptuado, en estos casos, como la entidad animada que instiga, controla y dirige de manera voluntaria el estado, acción o proceso representado (caso agentivo), aunque en ocasiones también se le asignan los papeles semánticos de paciente (caso dativo) o de ubicación u orientación espacial (caso locativo). Loc 1 reformula las palabras ajenas asumiendo el punto de vista de alguien involucrado directamente en la situación de que da cuenta el titular.

Los más frecuentes son casos en los que Loc 2 no es mencionado en el titular, pero sí en la nota informativa: representan el 36,8\% (1358/3689) de todos los encabezados del corpus. Dado que es así en todos los periódicos, no cabe duda de que la prensa hispánica tiende a no marcar la heteroglosia discursiva de retransmisión indirecta y a alinearse ideológicamente con un Loc 2 que ha hablado de una situación que involucra solo a terceros. Muy diversos pueden ser los motivos que animan a ello y casi todos tienen que ver con factores ideológicos de valoración de las fuentes informativas. Se halla en este caso más de la mitad de los encabezados en discurso indirecto no marcado de cada uno de los diarios. Registra El Comercio la mayor frecuencia de uso $(80,9 \%)$; la menor corresponde a El Universal $(51,5 \%){ }^{41}$

\footnotetext{
40 La relación exhaustiva: El País, 41,2\% (47/114); La Opinión, 28,4\% (31/109); El Universal, 46,6\% (151/324); La Nación, 25,5\% (54/212); Hoy, 42,4\% (112/264); El Tiempo, 22,2\% (39/176); El Nacional; 22,6\% (49/217); El Comercio, 15,2\% (39/257); El Mercurio, 28,8\% (63/219); Clarín, 11,4\% (17/149).

${ }^{41}$ El País, 53,5\% (61/114); La Opinión, 67,9\% (74/109); El Universal, 51,5\% (167/324); La Nación, 72,2\% (153/212); Hoy, 52,7\% (139/264); El Tiempo, 75\% (132/176); El Nacional; 72,8\% (158/217); El Comercio, 80,9\% (208/257); El Mercurio, 68,5\% (150/219); Clarín, $77,9 \%(116 / 149)$.
} 
Relativamente escasos en todas las publicaciones consideradas son los testimonios que no especifican la identidad de Loc 2 ni siquiera en el contexto. Si bien no han sido tomados en cuenta sino los casos en los que la nota informativa revela explícitamente la existencia de un discurso ajeno, ya hemos dicho que la incidencia se antoja mayor, a juzgar por los señalamientos de algunos estudiosos del periodismo. ${ }^{42}$ Con todo, observé en algún diario (Clarín) frecuencias que sobrepasan el $10 \%{ }^{43}$ Las motivaciones obedecen sobre todo, claro está, a rutinas informativas y a cautelas, compromisos e intereses socio-políticos de periodistas y fuentes de información.

\subsubsection{Discurso narrado}

Correspondiente en cifras generales al 23,6\% (872/3689) del corpus, el discurso narrado es la segunda modalidad más frecuente del discurso ajeno en los titulares. De acuerdo con mis materiales, la mayoría de los periódicos ámbito hispánico lo emplean para formular entre la cuarta y la quinta parte, aproximadamente, de los encabezados que describen actos discursivos ajenos. Están en ese caso El País, La Opinión, El Universal, El Nacional, El Comercio, El Mercurio y Clarín, es decir, el 70\% de los diarios de la muestra. Escapan de ese rango — del 20\% al 25\% - los diarios La Nación, El Tiempo y Hoy; los dos primeros exhiben incidencias menores y, el último, una frecuencia de uso sensiblemente más elevada. Los diarios El Comercio y La Opinión se ubican dentro del rango, pero muy cerca del límite inferior (véase la tabla general).

\footnotetext{
${ }^{42}$ Por ejemplo, Fontcuberta 1993: 61 y Rivadeneira Prada 2007: 99.

${ }^{43}$ El País, 5,3\% (6/114); La Opinión, 3,7\% (4/109); El Universal, 1,9\% (6/324); La Nación, 2,4\% (5/212); Hoy, 4,9\% (13/264); El Tiempo, 2,8\% (5/176); El Nacional; 4,6\% (10/217); El Comercio, 3,9\% (10/257); El Mercurio, 2,7\% (6/219); Clarín, 10,7\% (16/149).
} 
Esta variación responde a grados de asunción de la tendencia general y de si se adopta el comportamiento 1 o 2 . En efecto, la proporción de entre una cuarta y una quinta parte de discurso narrado sufre ciertas variaciones como resultado de los grados de predilección por los discursos directo e indirecto y no tanto - en principio - como consecuencia directa de una actitud hacia el propio discurso narrado, que, en comparación con las demás variedades puras del discurso ajeno, exhibe frecuencias de uso relativamente más homogéneas (tal como se aprecia en el diagrama 2, donde la franja que representa al discurso narrado zigzaguea con un espesor más o menos regular).

Son identificables cuatro sub-comportamientos a partir de la ya descrita diferenciación actitudinal con respecto al discurso directo (comportamientos 1 y 2) y del mayor o menor grado de adopción de la tendencia generalizada al uso predominante del discurso indirecto, que es nuestro punto de partida. Estos bien diferenciados sub-comportamientos son responsables de buena parte de la variación de frecuencias de uso del discurso narrado.

Comportamiento 1: $\quad$ discurso directo $>10 \%$.

Sub-comportamiento 1-A: menos discurso indirecto (más discurso narrado).

Sub-comportamiento 1-B: más discurso indirecto (menos discurso narrado).

Comportamiento 2: $\quad$ discurso directo $\leq 10 \%$.

Sub-comportamiento 2-A: menos discurso indirecto (más discurso narrado).

Sub-comportamiento 2-B: más discurso indirecto (menos discurso narrado).

Los sub-comportamientos 1-A y 1-B tienen en común, evidentemente, la incidencia de discurso directo superior al $10 \%$, pero se diferencian entre sí en que con el 1-A se acude menos al discurso indirecto $-\mathrm{y}$, por consiguiente, más al discurso narrado- que con el 1-B, y viceversa. Exhiben el subcomportamiento 1-A los diarios El País, El Universal, El Nacional, El Mercurio y Clarín, que presentan frecuencias de uso de discurso indirecto de entre el $51 \%$ y el $60 \%$ y de discurso narrado de entre el $22 \%$ y el $26 \%$. Por el contrario, El Tiempo adopta el sub-comportamiento 1-B porque prefiere el discurso indirecto en el $66 \%$ de sus titulares y el discurso narrado en el $18 \%$. 
Con los sub-comportamientos 2-A y 2-B, en cambio, se opta por el discurso directo en proporciones inferiores o iguales al 10\%. De la misma manera que sucede con el par anterior, se diferencian en que se acude menos con el 2-A al discurso indirecto - y, por tanto, más al discurso narrado- que con el 2-B, y viceversa. Hoy presenta el sub-comportamiento 2-A, con una incidencia de discurso indirecto del $62 \%$ y de discurso narrado del 32\%. Asumen el subcomportamiento 2-B los periódicos La Opinión, La Nación y El Comercio, ya que emplean el discurso indirecto con frecuencias del $72 \%$ al $75 \%$ y el discurso narrado con asiduidades de entre el $17 \%$ y el $22 \%$.

A pesar de que las frecuencias de uso de discurso narrado son clara consecuencia de las posturas asumidas con respecto a los discursos directo e indirecto, es innegable que existen ciertas actitudes adoptadas por los redactores de titulares en lo concerniente al discurso narrado en sí mismo. Así, puede decirse que a las condiciones que acabo de describir, impuestas por los discursos directo e indirecto, se añaden actitudes secundarias más favorables hacia el discurso narrado en los sub-comportamientos 1-A y 2-A que en los sub-comportamientos 1-B y 2-B.

\subsubsection{Formas mixtas}

La tendencia general que ya hemos descrito entraña un uso minoritario de las formas mixtas del discurso ajeno en los titulares periodísticos del ámbito hispánico. No obstante la relativa escasez de ejemplos, que representan apenas el 3,2\% (118/3689) del corpus, se observan peculiaridades que merecen ser examinadas.

Hemos dicho que las frecuencias de uso de las formas mixtas guardan una estrecha relación con el discurso directo. Esto es así porque el 68,6\% (81/118) 
de los encabezados en cuestión corresponde a testimonios de hibridación local, la cual incorpora, en todos los casos recogidos, secuencias en discurso directo. Si a ello se añaden los titulares de hibridación global que contienen secuencias en discurso directo, la proporción alcanza el 73,7\% (87/118).

Con esto en mente, puede suponerse que el comportamiento 1 es más favorable para las formas mixtas que el comportamiento 2. Así es, de hecho, en términos generales: aunque modestas, las más elevadas proporciones —entre el 5\% y el 8\%- se observan en El Mercurio, Clarín y El País, pertenecientes al grupo del comportamiento 1; por el contrario, las incidencias menores - entre el $0 \%$ y el 1\%— se presentan en La Opinión, La Nación y El Comercio, que ostentan el comportamiento 2 (en realidad, de este último periódico no recogí testimonio alguno de hibridación local).

Situaciones intermedias son, por un lado, las de los periódicos El Nacional, El Tiempo y El Universal, que, a pesar de asumir el comportamiento 1, presentan frecuencias aproximadas de entre el $2 \%$ y el $3 \%$; y, por otro, la de Hoy, integrante del grupo del comportamiento 2, que acude, sin embargo, a las formas mixtas en poco más del 3\% de sus titulares (véase la tabla general).

La relativamente alta frecuencia de uso de formas mixtas que ostenta Hoy — dada su escasa predilección por el discurso directo— se debe a que más de la mitad de sus encabezados de este tipo corresponde a testimonios de hibridación global ${ }^{44}$ y que, de ellos, casi el $89 \%{ }^{45}$ son casos que no incorporan discurso directo. En otras palabras, este diario también hace extensiva a las formas mixtas su marcada actitud de resistencia con respecto a las retransmisiones directas, a pesar de lo que pudiera suponerse a la vista únicamente de sus casi idénticas frecuencias de uso de discurso directo y de configuraciones híbridas.

\footnotetext{
${ }^{44}$ La cifra exacta es el 52,9\% (9/17).

${ }^{45} 88,9 \%$ (8/9).
} 
Habida cuenta de sus niveles de preferencia por el discurso directo, se esperaría que El Nacional, El Tiempo y El Universal emplearan las formas mixtas en proporciones similares a las del resto del grupo correspondiente al comportamiento 1. No se hallan, empero, dentro del rango esperable de entre el $5 \%$ y el $8 \%$, sino en otro que va, como hemos dicho, del $2 \%$ y al $3 \%$ (o sea, casi las proporciones observadas en los diarios que adoptan el comportamiento 2). Más extraño resulta si se tienen en cuenta los casos de hibridación global, cuya presencia, aunque escasa, impulsa a la baja aún más la frecuencia de uso de las formas mixtas que comportan segmentos de retransmisión directa.

Esta situación, sin embargo, puede explicarse atendiendo a motivos asociados con pruritos de corrección fomentados por ortografías, gramáticas de intención normativa, manuales de redacción periodística y libros de estilo. Al respecto conviene saber que, además de los ya referidos prejuicios puristas hacia las formas de hibridación local con estructuras receptoras en discurso indirecto marcado con conjunción explícita, no siempre está bien visto en el gremio periodístico el fenómeno textual de la "connotación autonímica"46 por razones que atañen a una búsqueda la llamada objetividad periodística como supuesto ideal de su ejercicio profesional: "No es aceptable [...] utilizar las comillas para ironizar sobre una expresión haciendo un guiño al lector y editorializando la información", 47 sentencia Pou Amérigo, por ejemplo.

Claro está que tales pruritos no parecen ser deseos compartidos por todos los redactores o revisores de titulares de todos los periódicos. Los testimonios de hibridación local, por ejemplo, están presentes en las planas de todas las publicaciones de la muestra, a excepción de El Comercio. Especialmente notorio es el caso de El País, pues todos sus encabezados de formas mixtas

\footnotetext{
${ }^{46}$ Authier 1981: 127.

${ }^{47}$ Pou Amérigo 2004: 255.
} 
(13/13) son de este tipo, en flagrante desacato a las disposiciones de su libro de estilo, ${ }^{48}$ que, además, son públicas y objeto de comercialización.

En los días considerados para la muestra contabilizada, las más altas asiduidades de hibridación local se presentaron en los diarios El País, La Opinión, El Universal, La Nación, El Tiempo, El Mercurio y Clarín (no se registraron casos de hibridación global en El País, La Opinión y El Tiempo). Mayores frecuencias de hibridación global que de local se atestiguaron en Hoy y El Comercio (sin registros de hibridación local este último). El periódico El Nacional registró, por último, idénticas proporciones de hibridación local y global. $^{49}$

\subsection{Aspectos cualitativos}

$\mathrm{Si}$ bien las preferencias por las distintas maneras de describir actos discursivos ajenos están motivadas por actitudes de los propios medios hacia las propias variedades del discurso ajeno, es evidente que la decisión de acudir a una en particular depende también de muchos otros factores. Se trata, sin duda, de un problema extremadamente complejo que involucra elementos

${ }^{48}$ Cf. El País 2003: 127.

${ }^{49}$ La relación exhaustiva:

\begin{tabular}{|l|l|l|}
\hline & Hibridación local & Hibridación global \\
\hline El País & $100 \%(13 / 13)$ & $0 \%(0 / 13)$ \\
\hline La Opinión & $100 \%(2 / 2)$ & $0 \%(0 / 2)$ \\
\hline El Universal & $72,2 \%(13 / 18)$ & $27,8 \%(5 / 18)$ \\
\hline La Nación & $66,7 \%(2 / 3)$ & $33,3(1 / 3)$ \\
\hline Hoy & $47,1 \%(8 / 17)$ & $52,9 \%(9 / 17)$ \\
\hline El Tiempo & $100 \%(6 / 6)$ & $0 \%(0 / 6)$ \\
\hline El Nacional & $50 \%(3 / 6)$ & $50 \%(3 / 6)$ \\
\hline El Comercio & $0 \%(0 / 1)$ & $100 \%(1 / 1)$ \\
\hline El Mercurio & $63,6(21 / 33)$ & $36,4 \%(12 / 33)$ \\
\hline Clarín & $68,4 \%(13 / 19)$ & $31,6 \%(6 / 19)$ \\
\hline
\end{tabular}


muy diversos ${ }^{50}$ como los contenidos noticiosos y su vínculo con la posición ideológica del medio o los propósitos del acto comunicativo dentro de una cierta situación socio-política, que deben ser estudiados en función de casos concretos.

Es probable que hayan influido en las frecuencias de uso de las formas del discurso ajeno, en particular en las variaciones menores, factores tan heterogéneos como, por ejemplo, las agendas informativas de los diarios analizados, pues varían en el tiempo los temas y los actores de la información considerada noticiosa, así como las opiniones que tienen los periodistas sobre ellos. Esto hace que, en un momento dado, abunden o escaseen las noticias merecedoras de titulares de cierto tipo.

En atención a esta problemática, plantearé sucintamente en las líneas siguientes algunas observaciones muy generales de índole semánticopragmático-discursiva - tradicionalmente olvidada por los especialistasque parecen influir en mayor o menor medida en el acto, realizado por el periodista en el momento de la enunciación, de tomar una resolución con respecto a qué variedad del discurso ajeno elegir para describir un acto discursivo ajeno.

\subsubsection{Doble escala}

Las modalidades discursivas aquí estudiadas se diferencian gradualmente según sus propiedades mimético-diegéticas y apropiativo-atributivas en relación con las palabras de Loc 2. Asistimos, pues, a una doble escala en los procesos lingüísticos del discurso ajeno.

\footnotetext{
${ }^{50}$ Cf. Gómez Mompart 1982: 53-68, Casado Velarde 1984: 237, López Hidalgo 2009: 61-
} 65 . 
El primer nivel, instaurado por el continuum que establece la díada mímesisdiégesis, es el definitorio de las variedades generales: la más mimética es, desde luego, el discurso directo, y la más diegética, el discurso narrado. El discurso indirecto ocupa una posición intermedia. Las distintas subvariedades, así como las formas mixtas, representan estadios diversos de este continuo. De manera general, es posible representarlo de la siguiente manera:

\section{Diégesis}

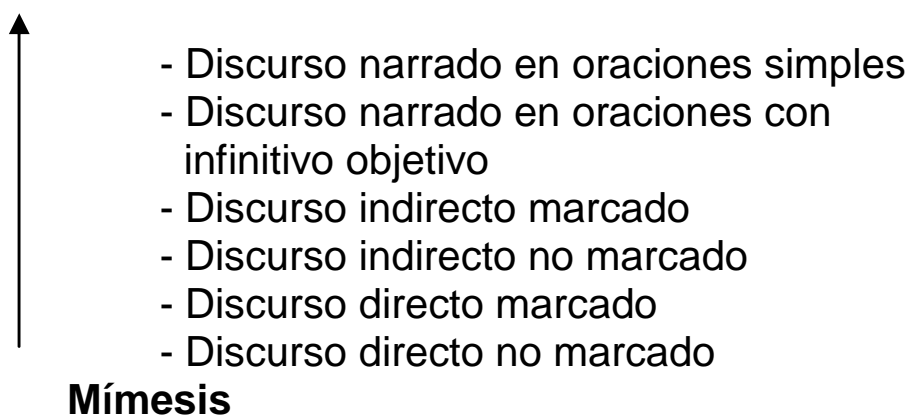

En principio, las formas marcadas del discurso ajeno comportan un distanciamiento de Loc 1 con relación a Loc 2 o bien a la forma o al contenido de su enunciado, y las no marcadas, una adhesión de Loc 1 con respecto al punto de vista de Loc 2. Se establece, pues, la segunda escala en las variedades del discurso ajeno: la que se instaura en el proceso de atribución-apropiación de la palabra. En la abstracción de un modelo coherente ideal, necesariamente hipotético, la escala se configura así:

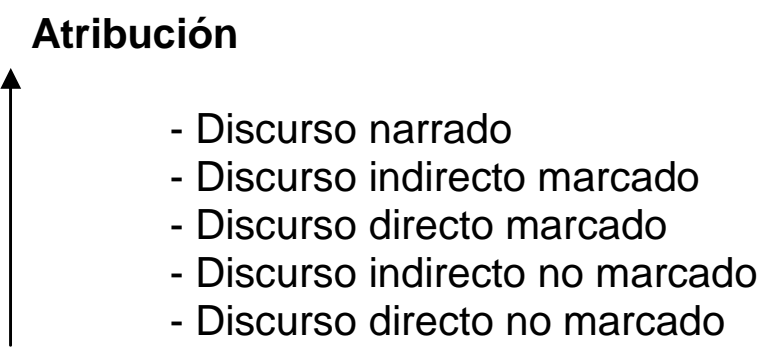

Apropiación 
Debo advertir, sin embargo, que dicho proceso no puede, de ninguna manera, reducirse a esto, pues, como bien se sabe, son muchos más los factores que determinan el sentido de los enunciados.

Por su naturaleza híbrida, las formas mixtas se sitúan en diferentes puntos intermedios de la doble escala. Los casos de hibridación local de mis materiales suponen siempre la interrupción de una secuencia más o menos diegética (la estructura receptora) para adoptar, temporalmente, una actitud mimética explícita no apropiativa que revela la existencia de una heteroglosia discursiva. En la hibridación global, en cambio, hay siempre una transición completa que modifica total o parcialmente los atributos mimético-diegéticos y apropiativo-atributivos del segmento inicial. Las formas mixtas se emplean con intenciones muy diversas, dadas las complejidades del juego especular que en ellas se observan.

De acuerdo con su ubicación en la doble escala, las formas del discurso ajeno permiten una diversificación en el estatuto de la importancia asignada a las fuentes informativas y a sus declaraciones, independientemente de los comportamientos asumidos por los diarios. Por un lado, en cuanto a la gradación mímesis-diégesis, puede decirse que, en general, Loc 1 asume o presenta como más importantes las palabras de Loc $2-$ y por tanto dignas de destacarse - si las retransmite en discurso directo, y menos importantes si las incluye, sin mencionarlas, como parte de un suceso de habla narrado. Por el otro, es necesario advertir que, en principio, Loc 1 asume o presenta a Loc 2 como una entidad más importante o confiable en la medida en que se apropie de las palabras ajenas sin atribuirlas a su fuente.

Cuanto más mimética es una variedad de discurso ajeno, tanto mayor es el protagonismo de la declaración aludida; en contraparte, este resulta menor en la medida en que aquella es aludida de manera más diegética. En el discurso directo, por ejemplo, Loc 1 asigna cierta prominencia a las palabras de Loc 2 
a causa de la interpretación convencional de supuesto respeto a la forma y el contenido del enunciado original, los cuales se asumen como relevantes, desde el punto de vista informativo, por el hecho mismo de la elección, por parte de Loc 1, de una variedad mimética. En el discurso narrado, en cambio, Loc 1 alude al acto de habla de Loc 2 de manera global, sintética e integrada, sin detenerse, necesariamente, a expresar el contenido o la forma de las palabras ajenas: es la variedad con propiedades analítico-temáticas más acentuadas; todo ello la hace ideal para aludir a información que se considera poco importante o que se desea disimular o marginar. Las formas diegéticas son, en principio, menos informativas que las miméticas.

En principio, las formas no marcadas del discurso ajeno suponen una mayor confianza de Loc 1 hacia Loc 2 que las variedades marcadas, y, por tanto, una proyección discursiva de este último como fuente informativa importante. El análisis polifónico al estilo de la ScaPoLine nos ha permitido comprobar que, salvo en casos de ironía, las formas no marcadas suponen una apropiación de las palabras ajenas tendente a la adhesión de Loc 1 al punto de vista asumido por Loc 2. La atribución, por el contrario, comporta un distanciamiento de Loc 1 con respecto a Loc 2 y su enunciado. Es muy revelador, por ejemplo, que las informaciones emanadas de organismos oficiales de estadísticas se codifiquen en los titulares, casi sin excepción, en discurso indirecto no marcado. Se deduce que el análisis del discurso ajeno en el periodismo puede contribuir, también, al estudio sistemático de las fuentes informativas.

\subsubsection{Aligeramiento y reiteración de marcas}

Se observa también cierta propensión al aligeramiento de marcas. En el discurso de los titulares, se hace necesario el empobrecimiento de la marcación del discurso ajeno, como parece indicar la elevadísima frecuencia 
de uso de formas no marcadas y la existencia de marcas de escaso peso formal, tales como los morfemas del condicional con valor de potencial citativo o la sola presencia de verbo o conjunción subordinante. Aunque es muy probable que no se trate de una característica exclusiva del discurso periodístico, parece ser síntoma de la necesidad, ideológicamente condicionada, de reducir la distancia establecida por los mecanismos de atribución, a fin de que Loc 1 se apropie de las palabras ajenas, ya sea con la intención de asumir o no el punto de vista con el que Loc 2 se identifica. El avance de formas innovadoras como parece ser, como venimos diciendo, una respuesta a necesidades de comunicación algo más complejas que el "afán urgente de los grupos por diferenciarse y jergalizarse", 51 como afirma Lázaro Carreter al censurar el uso "extravagante" del potencial citativo en el discurso periodístico.

La elisión de verbos de habla obedece también, al menos en parte, a pretensiones de neutralidad aparente. ${ }^{52}$ Dado que la interpretación del acto de habla ajeno recae, en buena medida, en los verbos de habla, podemos suponer que la omisión de estos se debe, además de a las necesidades económicas propias del género discursivo, a una intención de no expresar la lectura que Loc 1 hace del hecho lingüístico noticioso; ello contribuye a la configuración de una imagen discursiva de locutor neutral y sobrio. Parece comprobarlo el hecho de que los verbos de habla no siempre se eliden, ni siquiera aquellos completamente genéricos, como decir.

Las marcas dobles del discurso directo encuentran motivación —además de en la evidente búsqueda del prestigio social vinculado con una tradición ortográfica- en el refuerzo de cualidades miméticas no apropiativas. Al igual que en las formas mixtas con hibridación local, las marcas ortográficas de constituyentes suelen llevar consigo un efecto de sentido, muchas veces

\footnotetext{
${ }^{51}$ Lázaro Carreter (1986) 1998: 386.

${ }^{52}$ Según Hurtado (2009: 198), con este tipo de elipsis "se logran titulares más ágiles, dramáticos y directos".
} 
irónico, por medio del cual Loc 1 manifiesta su discordancia con el punto de vista asumido por Loc 2 o bien señala que las palabras reproducidas pertenecen a un registro lingüístico que considera impropio o, al menos, no ejemplar. La necesidad de una reiteración de la actitud mimética comprueba el estatuto de mera suposición del significado de retransmisión literal que se asocia convencionalmente al discurso directo.

\subsubsection{Orientación argumentativa}

En los titulares periodísticos, la confluencia de discursos sobre un mismo asunto, procedentes de distintas entidades insertas en una coyuntura sociohistórica, forma una escena virtual de diálogo entre ellas. Esto se debe a que, en el discurso periodístico, los enunciadores ${ }^{53}$ poseen frecuentemente un correlato en la realidad efectiva: las fuentes informativas. Recuérdese, con Bajtín, Ducrot y la ScaPoLine, que el habla del otro, y por tanto el punto de vista ajeno, son parte, a veces indistinguible, del discurso y el pensamiento propio.

Dado el conjunto de posibilidades de que dispone Loc 1 para dar cuenta de un acontecimiento verbal, la elección de determinada variedad del discurso ajeno, y no otra, debe considerarse significativa, pues responde a estrategias discursivas específicas, motivadas por patrones ideológicos compartidos por Loc 1 y la organización informativa. El periodista y el diario adoptan, pues, una actitud ante el suceso verbal referido, lo cual, sin duda, es indicador de líneas editoriales. No debe olvidarse que el periodismo es, en realidad, un aparato técnico de difusión y legitimación de ideologías.

\footnotetext{
${ }^{53}$ Es decir, de acuerdo con Ducrot ([1984] 1986: 209), las entidades discursivas que presentan los puntos de vista que exhiben los enunciados.
} 
En el discurso de los titulares, el uso de las diversas modalidades del discurso ajeno obedece a una estrategia persuasiva de Loc 1, que puede develarse si se analiza el sentido del discurso periodístico. Esta es diferente en cada caso, pues depende de la forma y el contenido de las palabras de Loc 2, así como de las situaciones de enunciación originaria y actualizadora, comprensivas, naturalmente, de las intenciones e ideologías subyacentes de la organización informativa y de los locutores primario y secundario. Los titulares con discurso ajeno ofrecen una orientación argumentativa:

1. Por medio de la elección de ciertos argumentos que se retienen prioritariamente y que llevan a un determinado tipo de conclusiones. El hecho de llamar la atención hacia determinada información, y no otra, ocasiona que la interpretación del acontecimiento noticioso que haga el lector sea, necesariamente, parcial o sesgada.

El omitir información, o el expresarla con mayor o menor grado de detalle, son algunos mecanismos concretos que, para este fin, se emplean en la codificación de los encabezados. Así, por ejemplo, Loc 1 asigna mayor o menor importancia a los locutores secundarios de acuerdo con el grado de detalle con el que los alude: Loc 2 puede mencionarse de manera concreta y específica, de modo general e inespecífico, o simplemente no ser mencionado. Como es obvio, un sujeto explícito determinado con semantismo propio goza de un protagonismo del que carece una fuente informativa oculta tras un sujeto tácito, una nominalización deverbal o una voz pasiva con omisión de complemento agente.

2. Por medio de elecciones léxicas con un determinado peso argumentativo. El hecho de representar la realidad con palabras exige, obviamente, la selección de unidades pertenecientes al 
inventario léxico de la lengua. La interpretación que ello supone es impuesta al alocutario en el acto de enunciación, siempre que, como suele ocurrir en el discurso periodístico, el receptor no haya constatado personalmente la entidad representada. En el caso del discurso ajeno, Loc 1 impone al destinatario su lectura del acto de habla de Loc 2.

Las elecciones léxicas concretas, siempre subjetivas, ${ }^{54}$ orientan el enunciado hacia determinadas conclusiones, que, en los titulares periodísticos, permiten develar la postura de la organización informativa. Los verbos de habla, por ejemplo, conllevan la elección de argumentos que apuntan en sentidos diferentes, encaminados siempre a determinar la comprensión que, del suceso enunciativo, tenga el lector. Lo mismo puede decirse de todas las valoraciones y constataciones de carácter positivo o negativo.

3. Mediante información presupuesta. Los titulares suelen incorporar información, muchas veces comprometedora, como algo evidente o ya conocido $y$, por tanto, imposible de poner en duda sin caer en una confrontación. Los contenidos presumiblemente novedosos aparecen con frecuencia enmarcados por información asumida como indiscutible, que, a final de cuentas, determina el sentido general del enunciado, y, por consiguiente, orienta la interpretación de la noticia. Aposiciones, oraciones subordinadas y verbos factivos $^{55}$ son algunos de los mecanismos de introducción de presupuestos más usuales en los titulares.

\footnotetext{
${ }^{54}$ Cf. Kerbrat-Orecchioni 1980.

${ }^{55}$ Entendido este término en su acepción más amplia, a saber: verbos que, precisamente, transportan la presuposición de cierto valor de verdad del contenido proposicional, tales como admitir, reconocer, lamentar o advertir.
} 
4. Gracias a la construcción de un éthos discursivo. Con fines persuasivos, Loc 1 genera una imagen de sí mismo en su discurso. ${ }^{56}$ Por ejemplo, la atribución de palabras y la mención de datos precisos, como fuentes informativas y cifras busca, en los titulares, la formación de un éthos que trasluzca la existencia de un Loc 1 erudito, riguroso y bien informado del acontecer noticioso, cuyas palabras encierren información verdadera, constatada y comprobable; debido a la distancia que marca la atribución explícita, Loc 1 se muestra, además, como si expusiera el acontecimiento de manera "imparcial y objetiva". Todo esto se traduce en la configuración de la imagen discursiva de un locutor digno de credibilidad. ${ }^{57}$

5. Por medio de la estructuración de discursos bivocales de orientación múltiple. En estos casos, por lo general de discurso directo no marcado, Loc 1 aprovecha la condición pasiva de las palabras ajenas para actualizarlas con un sentido muy distinto del que originalmente tenían, con la intención de manifestar un punto de vista discordante.

6. Mediante segmentos discursivos insertos en contextos tendenciosos. En algunas ocasiones, las formas mixtas con hibridación local comportan la inserción de un fragmento del enunciado ajeno, descontextualizado, en una construcción que sugiere conclusiones muy diferentes de las originales.

${ }^{56}$ Cf. Puig 2005: 325, 2010.

${ }^{57} C f$. Romero Álvarez 2000, entre otros. 


\section{Conclusiones}

1. Una de las funciones referenciales del discurso es generar imágenes de otros discursos. Esto constituye, al mismo tiempo, un rasgo común a todas las lenguas del mundo y un fenómeno general del habla, presente en todos, o casi todos, los usos discursivos. ${ }^{1}$ Para algunos investigadores ${ }^{2}$ representa, incluso, una peculiaridad universal del comportamiento humano. Por cuanto el discurso ajeno se vale, en muchos casos, de esta capacidad del lenguaje de representarse a sí mismo, no es extraño que, desde la Grecia clásica, sea un asunto importante en la retórica.

2. Solo en fechas recientes, sin embargo, ha empezado a estudiarse el discurso ajeno como fenómeno lingüístico que interesa no solamente a críticos y teóricos de la literatura. Aunque notables, los avances han resultado, en general, muy limitados a causa del persistente afán por reducir el asunto a los dominios de teorías y métodos inoperantes a la hora de concebir y abordar el origen del problema: su naturaleza discursiva. El estudio del discurso ajeno trasciende no solo las difusas fronteras de los niveles de descripción lingüística, sino también los límites disciplinarios. ${ }^{3}$

3. Los titulares periodísticos constituyen un registro lingüístico de especial interés para el estudio del discurso ajeno, pues en ellos la incidencia de este sobrepasa el $60 \%$ de los casos.

4. En esta investigación, me he propuesto caracterizar y describir el discurso ajeno en los titulares periodísticos con la intención de dilucidar cuestiones

\footnotetext{
${ }^{1} C f$., entre otros, Jakobson (1936-1963) 1981: 308-309, Li 1986: 39-40, Collins 2001: 1, Sakita 2002: 2, Coulmas 1986: 2.

${ }^{2}$ Por ejemplo, Haberland 1986: 219.

${ }^{3}$ Cf. Coulmas 1986: 1, Sakita 2002: 5-11.
} 
relacionadas con los fenómenos generales de alusión o presencia de un enunciado ajeno en el propio; pero, también, con el interés de describir y explicar los mecanismos específicos en que esto se presenta dentro de los encabezados, que son la parte más importante del discurso informativo. ${ }^{4}$

En cuanto al segundo objetivo, me he limitado, en la medida de lo posible, a los aspectos más formales de la estructura lingüística, de manera tal que el análisis cuantitativo proporcione datos fecundos. La indagación cualitativa no ha sido — ni ha pretendido ser- exhaustiva: se ha restringido a una labor netamente exploratoria, destinada a abrir el camino para investigaciones complementarias. De momento, es posible asegurar que el discurso ajeno no debe concebirse de manera fragmentada, es decir, como una serie de fenómenos aislados, pertenecientes a distintos niveles de descripción lingüística. Ello implica sesgos muy graves, que suponen, entre otras cosas, la omisión de por lo menos el 50\% del universo de estudio.

5. Por discurso ajeno se ha entendido aquí el conjunto de procedimientos de descripción de un acto discursivo ajeno en el propio. Siguiendo los planteamientos de Voloshinov, el objeto de estudio se ha circunscrito a todo discurso o segmento discursivo que trasluzca, de manera explícita o implícita, la alusión o presencia de un enunciado ajeno en el propio. El discurso ajeno es, por consiguiente, un asunto de índole discursiva y no siempre exclusivamente oracional (con mucha frecuencia se suele reducir el asunto a algunos procedimientos morfosintácticos de incorporación de las palabras ajenas en el discurso propio).

6. La descripción y caracterización del discurso ajeno ha exigido, por la naturaleza misma del asunto, un tratamiento epistemológico ad hoc, que recupere, de manera integradora, métodos y teorías de procedencias diversas, siempre que aporten elementos pertinentes para el conocimiento de los

${ }^{4}$ Van Dijk (1988a) 1997: 134. 
fenómenos presentes en el corpus. Esto ha supuesto tomar en consideración factores muy diversos —ortográficos, morfológicos, sintácticos, semánticos, pragmáticos, modales-, bien entendido que el conocimiento general de los fenómenos del discurso ajeno solo puede ser satisfactorio si trasciende los niveles de descripción lingüística.

7. En este trabajo, he propuesto un modelo de análisis del discurso ajeno a partir de un corpus de titulares periodísticos. Si bien me he centrado en las singularidades que se presentan en este registro lingüístico, el esquema general puede hacerse extensivo a otros usos discursivos. El modelo se basa en tres variedades puras - discurso directo, discurso indirecto y discurso narrado- $-\mathrm{y}$ en varias combinaciones entre estas.

8. El discurso directo se caracteriza por la retención del sistema deíctico de Loc 2 en el segmento que representa la declaración ajena y se asocia convencionalmente con el polo semántico de una supuesta retransmisión literal: comporta una actitud histriónica por parte de Loc 1 y, en consecuencia, una intención mimética.

8.1. En función de su complejidad estructural, se identifican dos grandes variedades: marcado y no marcado. En la primera, se añade explícitamente alguna forma al supuesto enunciado de Loc 2 a fin de sugerir la existencia de una retransmisión literal; en la segunda, el supuesto enunciado de Loc 2 se retransmite sin indicaciones explícitas.

8.2. En mis materiales solamente registro, como marcas, verbos de habla subordinantes e índices gráficos, o una combinación de ambas. El verbo subordinante puede hallarse expreso o elidido, y el segmento que lo contiene, que hemos llamado S1, puede situarse en los titulares antes o después de las palabras ajenas, que hemos denominado $\mathrm{S} 2$. El eje deíctico de $\mathrm{S} 1$ es Loc 1, y el del S2, Loc 2. En el caso de las formas marcadas, el anclaje de S2 es 
denunciado, más que por formas lingüísticas contenidas en él, por la estructura sintáctico-ortográfica que lo rodea. Las estructuras abstractas que he descrito en páginas anteriores se asocian con la significación general del discurso directo - $-\mathrm{y}$ por tanto con un S2 anclado situacionalmente en Loc 2-, debido al principio de la irrenunciable correspondencia entre forma y significado: ya en el signo, ya en la estructura que lo contiene.

8.3. La retransmisión literal del discurso directo no es más que un supuesto, incluso en las variedades marcadas o doblemente marcadas. Al contrario de lo que suele decirse, el discurso directo no garantiza un respeto total a la forma del enunciado originario, sino únicamente un mantenimiento del anclaje deíctico en Loc 2. En principio, las marcas dobles enfatizan la supuesta literalidad de $\mathrm{S} 2$, como resultado de la contrariedad que se presenta entre esta situación y las necesidades inherentes al discurso periodístico de insuflar veracidad al texto: la marca del verbo subordinante - en cualquiera de las estructuras aquí descritas - aporta una instrucción interpretativa básica de transcripción literal de S2, y la marca ortográfica subraya que debe interpretarse así alguno de sus constituyentes en particular. En la mayoría de los casos se trata de todo el S2, pero no siempre. Sea como fuere, la posibilidad de destacar como reproducción literal parte de lo así ya marcado implica que, en el discurso de los titulares periodísticos, la esencia selectiva del discurso directo puede llevarse sucesivamente a diversos niveles intratextuales, sin que en ningún caso ello garantice una verdadera correspondencia entre S2, o alguna parte de él, y las palabras realmente emitidas por Loc 2.

9. El discurso indirecto es la variedad del discurso ajeno que siempre muestra una reformulación analítica del enunciado original, la cual comporta, en principio, transposiciones deícticas de persona cuando en el enunciado primario se alude explícitamente a algún participante de los cuadros 
figurativos de la enunciación primaria o secundaria. El texto producido no tiene más que un eje deíctico, el de Loc 1.

9.1. Al igual que el discurso directo, esta variedad del discurso ajeno se presenta de forma marcada y no marcada.

9.2. La marca más frecuente de reformulación analítica es una oración subordinante acompañada por una conjunción, casi siempre que. Registro también, sin embargo, estructuras elípticas que prescinden del verbo o la conjunción, además de la preposición para seguida por un sintagma nominal en un adjunto periférico y de secuencias que contienen usos del condicional con valor de potencial citativo.

10. Con el discurso narrado, Loc 1 refiere el acto de habla ajeno como cualquier otro tipo de acción, esto es, sin acudir a las estructuras de los discursos directo o indirecto marcados, que son configuraciones morfosintácticas especializadas en la representación discursiva. Esta forma de aludir a la enunciación ajena no es sino la expresión narrativizada de la lectura que Loc 1 hace del acto de habla de Loc 2: constituye la variedad más diegética del discurso ajeno.

10.1. Capaz de representar o no el enunciado de Loc 2, el discurso narrado se estructura en frases nominales o bien en predicados intransitivos o transitivos, $\mathrm{y}$, en el caso de estos últimos, los objetos directos o prepositivos, oracionales o no, jamás están separados del resto del titular por medio de índices gráficos.

10.2. El discurso narrado es la variedad que menos atención ha recibido por parte de los especialistas, acaso debido a las dificultades de caracterización que plantea. En este trabajo, he propuesto una clasificación a partir de los significados denotativos comunes de los verbos de habla, que representan siempre marcas de discurso ajeno. 
11. Las formas mixtas constituyen fórmulas discursivas que presentan características de más de una variedad pura del discurso ajeno. La hibridación es local si la cláusula, integrada en estos casos únicamente por una frase, oración o período, muestra propiedades distintivas de más de una variedad pura; es global si, en la cláusula, se enlazan paratácticamente frases, oraciones o períodos que, por separado, se interpretan como variedades puras. En los testimonios que recojo, estas formas tienen como origen, en cada caso, un mismo acto o macro-acto de habla, y, por consiguiente, un mismo Loc 2.

12. Una marca de discurso ajeno es un elemento lingüístico explícito que aporta un significado de alusión o presencia de un enunciado ajeno en la propia. $^{5}$ Las formas no marcadas de los discursos directo e indirecto solo pueden identificarse por medio de una comparación rigurosa entre texto y contexto.

Son los verbos de habla explícitos la única marca de discurso ajeno presente en las tres variedades puras; por tanto, únicamente pueden establecerse comparaciones formales rigurosas entre las estructuras que contienen verbos de este tipo. En la siguiente matriz, he agrupado los rasgos estructurales distintivos de las secuencias que presentan dichas características (discursos directo, indirecto y narrado):

\begin{tabular}{|l|l|l|l|}
\cline { 2 - 4 } \multicolumn{1}{c|}{} & $\begin{array}{l}\text { Discurso directo } \\
\text { marcado con } \\
\text { verbo expreso }\end{array}$ & $\begin{array}{l}\text { Discurso } \\
\text { indirecto } \\
\text { marcado con } \\
\text { verbo expreso }\end{array}$ & $\begin{array}{l}\text { Discurso } \\
\text { narrado } \\
\text { oracional }\end{array}$ \\
\hline Objeto directo marginado & + & - & - \\
\hline $\begin{array}{l}\text { Objeto directo oracional } \\
\text { con verbo en forma } \\
\text { personal }\end{array}$ & + & + & - \\
\hline
\end{tabular}

\footnotetext{
${ }^{5}$ En muchos casos es, además, adicionador de complejidad estructural.
} 
En efecto: 1) a diferencia de las otras variedades, el discurso directo marcado con verbo de habla explícito siempre presenta marginados los objetos directos, es decir, aislados del resto de la oración por medio de índices gráficos; 2) solo en el discurso narrado los objetos directos oracionales contienen verbos en forma no personal; 3) el discurso indirecto marcado con verbo de habla carece, al igual que el discurso narrado, de objetos directos marginados, y, del mismo modo que el discurso directo marcado - al menos en mis materiales-, ostenta invariablemente objetos directos con verbo en forma personal cuando estos son oracionales. En los ejemplos de la serie (1), correspondientes a un mismo acto verbal, puede advertirse que la fórmula directa —ejemplo (1a) — se distingue por la existencia de un objeto directo marginado con verbo en forma personal; la indirecta — testimonio (1b)—, por un objeto directo no marginado con verbo en forma personal; y la narrativizada — caso (1c)—, por un objeto directo no marginado con verbo en forma no personal.

(1) a. Nunca hubo una negociación en lo oscurito, afirmó Creel [LAP 23/02/05: 33]

b. Rechaza la Segob que se negocie el desafuero de AMLO [SOL 23/02/05: 3/A]

c. Niega Segob negociar con la ley [REF 23/02/05: 4A]

Puede decirse que las configuraciones gramaticales abstractas de los ejemplos de la serie (1) —integrantes, como acabamos de ver, de un sistema formal de oposiciones - representan estructuras básicas de las variedades puras del discurso ajeno en los titulares periodísticos (esto no significa, desde luego, que sean necesariamente las construcciones prototípicas o más abundantes). El resto de las formas no mixtas podrían organizarse alrededor de estos tres puntos de comparación: se sitúan en una posición más distante en la medida en que las marcas se refuerzan, se aligeran o se pierden del todo (es en las formas más apartadas donde se hace evidente la necesidad de concebir el discurso ajeno como un asunto de índole discursiva y no exclusivamente 
oracional). Puesto que se forman a partir de variedades puras, las estructuras mixtas se ubican en diversos puntos intermedios.

13. Existe en el mundo hispánico una tendencia a formular en discurso indirecto los titulares periodísticos que describen un acto discursivo ajeno. Los periódicos de la muestra cuantificada sitúan en segundo lugar de preferencia el discurso narrado y, en tercero, el discurso directo. Las formas mixtas son claramente minoritarias. La tendencia general es, pues, la siguiente: discurso indirecto > discurso narrado > discurso directo > formas mixtas.

14. El discurso indirecto registró en mis materiales una frecuencia de uso general del 61,2\%. La incidencia media del discurso narrado fue del 23,6\%; la del discurso directo, del 12\%, y la de las formas mixtas, del 3,2\%.

15. Las variaciones que presentan los diarios parecen estar asociadas con un relativo proceso de estigmatización del discurso directo en los titulares, lo cual da lugar a dos comportamientos según sea que los redactores de titulares estén más o menos sensibilizados: he llamado comportamiento 1 al que presenta frecuencias de uso de discurso directo mayores al $10 \%$ y comportamiento 2 al que presenta incidencias menores o iguales al $10 \%$.

15.1. El comportamiento 1 es adoptado por los diarios El País (Madrid), Clarín (Buenos Aires), El Universal (México), El Tiempo (Bogotá), El Nacional (Caracas) y El Mercurio (Santiago de Chile). El comportamiento 2 es exhibido por los diarios La Opinión (Los Ángeles), Hoy (Santo Domingo), El Comercio (Lima) y La Nación (San José de Costa Rica).

15.2. En general, ostentan el comportamiento 2 los periódicos que presentan acentuada la tendencia general. Estas publicaciones suelen registrar muy elevadas incidencias de discurso indirecto y bajas frecuencias de uso tanto de 
formas mixtas como de discurso directo. Esto se debe, en parte, a que las formas mixtas son, mayoritariamente, estructuras que combinan discurso directo con otras modalidades del discurso ajeno. El escaso empleo del discurso directo y las formas mixtas impulsa, desde luego, el aumento de la asiduidad de los discursos narrado e indirecto.

16. Esa estigmatización no parece estar muy generalizada, a pesar del repudio expresado hacia el discurso directo en diversos manuales de redacción periodística y libros de estilo. Tal situación da lugar al comportamiento 1 (en ningún caso el discurso directo supera el $20 \%$ de los titulares). Debido a que las formas mixtas se vinculan claramente con el discurso directo, no es extraño que las publicaciones que exhiben este comportamiento ostenten asimismo las más altas incidencias de uso de configuraciones híbridas, a pesar, también, de las críticas de ciertos gramáticos y de las proscripciones de algunos libros de estilo.

17. El uso de discurso narrado oscila en la mayoría de los diarios entre el $20 \%$ y el 25\%. Las variaciones responden, en principio, a grados de asunción de la tendencia general y de si se adopta el comportamiento 1 o 2, y no tanto como consecuencia directa de una actitud hacia el propio discurso narrado, que, en comparación con las demás variedades puras del discurso ajeno, exhibe frecuencias de uso relativamente más homogéneas.

18. Se identifican, pues, cuatro sub-comportamientos: $1-A$ si el diario adopta el comportamiento 1 y no asume en grado extremo la tendencia general; $1-B$ si exhibe el mismo comportamiento pero sí asume en extremo la tendencia general; $2-A$ si exhibe el comportamiento 2 y no ostenta de modo muy acentuado la tendencia general, y 2-B si adopta el comportamiento 2 pero sí mantiene en grado extremo la tendencia general. Por asumir en menor grado la tendencia general, los dos sub-comportamientos A presentan incidencias de 
discurso indirecto menos altas que los sub-comportamientos $\mathrm{B} y$, por consiguiente, emplean el discurso narrado con mayor asiduidad.

Exhiben el sub-comportamiento 1-A El País, El Universal, El Nacional, El Mercurio y Clarín; el diario El Tiempo adopta el sub-comportamiento 1-B. Presenta Hoy presenta el sub-comportamiento 2-A y asumen el 2-B los periódicos La Opinión, La Nación y El Comercio.

19. Si bien las frecuencias de uso de discurso narrado son clara consecuencia de las posturas asumidas con respecto a los discursos directo e indirecto, es innegable que también existen ciertas actitudes en lo concerniente al discurso narrado en sí mismo. Puede decirse que, a las condiciones recién descritas, se añaden, evidentemente, actitudes secundarias más favorables hacia las formas narrativizadas en los sub-comportamientos 1-A y 2-A que en 1-B y 2-B.

20. Ha quedado revelado el enorme sesgo que entrañan las clasificaciones tradicionales del discurso ajeno. Por ignorar todas las formas del discurso narrado y del indirecto no marcado, las concepciones más tradicionales desatienden por lo menos el $79 \%$ de los titulares que describen un acto discursivo ajeno. Por cuanto no se trata de estructuras privativas de los encabezados ni de la lengua escrita, es muy probable que el sesgo con respecto al habla cotidiana sea parecido.

21. En cuanto al discurso directo, las variedades marcadas representan el $96 \%$ de los casos, y las no marcadas, el $4 \%$ restante. De manera general, las marcas de discurso directo más abundantes son las exclusivamente gráficas, con el $58,2 \%$; después están los verbos de habla subordinantes, con el $25,8 \%$ y, por último, los casos de doble marca, con el $16 \%$.

21.1. Los diarios de España (El País), Costa Rica (La Nación), Colombia (El Tiempo), Venezuela (El Nacional), Perú (El Comercio), Chile (El Mercurio) y 
Argentina (Clarín) acuden a marcas exclusivamente ortográficas en proporciones que oscilan entre el 60\% (El Mercurio) y el 90\% (El País). Las publicaciones de Estados Unidos (La Opinión) y México (El Universal) prefieren, en cambio, marcas exclusivamente sintácticas —es decir, verbos subordinantes expresos o elípticos- en la mayoría de sus encabezados en discurso directo marcado. La mayor parte de los pocos titulares del diario dominicano (Hoy) corresponde, por último, a marcas dobles.

21.2. En estructuras de discurso directo elípticas con marca redundante o sin ella, el orden de constituyentes que antepone la mención del declarante a la reproducción de la declaración, que hemos llamado S1-S2, es, en términos generales, menos frecuente que la pauta $\mathrm{S} 2-\mathrm{S} 1$, pero se encuentra mucho más generalizado. Se observa en todos los periódicos, aunque con particular insistencia en el español El País, el chileno El Mercurio, el argentino Clarín, el costarricense La Nación, el dominicano Hoy y el venezolano El Nacional. Por el contrario, la disposición S2-S1 en construcciones elípticas de discurso directo se observa solamente en el colombiano El Tiempo, el mexicano El Universal, el estadounidense La Opinión y el dominicano Hoy. Si bien esta última pauta no es un rasgo común a toda la prensa hispánica — ni siquiera hispanoamericana-, no se trata, en definitiva, de una característica exclusiva de los diarios mexicanos, como suele decirse.

21.3. Debido a que la frecuencia de los titulares con orden $\mathrm{S} 1-\mathrm{S} 2$ se incrementa notablemente cuando hay comillas e incluso hay un periódico ( $E l$ País) que solo acude a este orden cuando S2 se entrecomilla, es posible asegurar que existe una tendencia en la prensa hispánica a asignar un carácter formulaico al orden S1-S2 con las palabras de Loc 2 marcadas ortográficamente. Esto no se observa en los casos con el orden S2-S1, que suele aparecer sin comillas. El periódico español El País y el chileno El Mercurio no presentan casos de discurso directo señalado por únicamente el 
verbo de habla debido a que no publican encabezados con retransmisiones literales marcadas sin comillas.

21.4. Los periódicos de América del Norte y del Caribe insular tienden dan prioridad a marcas distintas de las comillas solas, a diferencia de los diarios de Europa, América Central y América del Sur. Aunque en los diversos periódicos del ámbito hispánico se presentan otras soluciones, las marcas ortográficas empleadas para indicar el cambio de nivel discursivo de en las reproducciones directas marcadas con verbo elíptico fueron siempre dos puntos en los casos de orden S1-S2, y coma o dos puntos en los de S2-S1.

21.5. Los casos de discurso directo no marcado se presentaron únicamente en los diarios Clarín, El Comercio, El Mercurio, El Tiempo, El Universal y Hoy del corpus cuantificado. Sin embargo, los datos del corpus piloto permiten suponer que el fenómeno se presenta en periódicos de todo el mundo hispánico, en especial en los de corte popular-sensacionalista o en las secciones poco relevantes desde el punto de vista político-económico.

22. En lo concerniente al discurso indirecto, todos los periódicos de mis materiales acuden a él en proporciones que exceden el 50\%. El 90,5\% de estos casos está representado por reformulaciones analíticas no marcadas, mientras que solo el 9,5\% corresponde a formas marcadas. De todas las variedades del discurso ajeno, el discurso indirecto no marcado es, por sí solo, la más frecuente: representa el 55,3\% de todo el corpus. Constituye, sin lugar a dudas, la solución preferida por los periodistas para aludir a actos discursivos ajenos, al menos en los encabezados.

22.1. Casi todos los periódicos exhiben claras preferencias por determinadas indicaciones textuales de reproducción analítica. En El País, Clarín, El Nacional, El Universal y La Opinión, la marca más frecuente es una oración subordinante acompañada por la conjunción que. El periódico Hoy prefiere, 
en cambio, la estructura con conjunción elidida, mientras que El Mercurio, $\mathrm{La}$ Nación y El Tiempo optan con mayor frecuencia por usos del potencial citativo. El Comercio registra un equilibrio, con poco menos de la mitad de los casos, entre el potencial citativo y el verbo y la conjunción explícitos.

22.2. Todos los periódicos recurren en sus titulares a la estructura con verbo y conjunción explícitos. Solo la utilizaron en menos del 50\% de los casos de discurso indirecto marcado los diarios Hoy, El Tiempo, La Nación, El Mercurio y El Comercio.

22.3. A pesar del repudio de ciertos gramáticos y hasta de algunos libros de estilo, el potencial citativo fue empleado en todos los periódicos, salvo $L a$ Opinión; en menos de la mitad de los casos, eso sí, en El País, Clarín, El Nacional, Hoy, El Universal y El Comercio.

22.4. Registré testimonios de conjunción elidida únicamente en los periódicos Hoy y El Universal, aparentemente a causa de que estas son las publicaciones del corpus cuantificado que ostentan mayor cantidad de omisiones de determinantes, preposiciones y conjunciones. La elipsis de verbo de habla fue registrada en Clarín, El Comercio, El Mercurio y El Universal, pero el corpus piloto permite descartar la idea de que sea algo inusual o privativo de tales periódicos; todos los ejemplos contabilizados son testimonios con según.

22.5. Proceden de Clarín y El Universal todos los testimonios de discurso indirecto introducido por la preposición para que fueron sometidos a cuantificación. Se llegan a observar, sin embargo, en otras publicaciones. Infrecuentes en todo caso, los titulares de este tipo siempre presentan en posición inicial la preposición para, a diferencia de los encabezados con según, que invariablemente registran esta conjunción después de las palabras ajenas reformuladas. Parece existir, en consecuencia, una especialización de uso: para en los casos de S1-S2 y según en los de S2-S1. 
23. La variación en las frecuencias de uso del discurso narrado tiene que ver con los cuatro sub-comportamientos que he descrito.

23.1. Esta variedad del discurso ajeno puede ser, a diferencia de las otras, más o menos informativa con respecto al contenido del enunciado ajeno: la gradación se extiende desde la informatividad casi nula hasta la especificación completa, lo cual demuestra el error que comporta la arraigada hipótesis de la representación discursiva como criterio definitorio del discurso ajeno.

23.2. Si bien, como señalan Leech y Short, ${ }^{6}$ el discurso narrado es más indirecto que el discurso indirecto, las formas narradas no son uniformemente indirectas: se presentan en estructuras transitivas (directas y prepositivas), intransitivas y nominales. En principio, las configuraciones nominales son menos directas que las intransitivas y, a su vez, estas últimas lo son menos que las transitivas. Las formulaciones intransitivas y nominales tienden a no representar las palabras ajenas (es decir, a ser poco icónicas), pero sí a evaluar y describir de manera global el acto de habla ajeno. Las construcciones transitivas se presentan en oraciones simples o bien en oraciones con infinitivo objetivo, de las cuales las más icónicas o miméticas son las que contienen el verboide (razón por la que algunos especialistas, incluidas las Academias, las han confundido, acaso sin darse cuenta, con el discurso indirecto marcado). En mis materiales, el 75,1\% de los casos de discurso narrado corresponde a oraciones simples (transitivas e intransitivas); el $20,8 \%$, a oraciones con infinitivo objetivo, y solo el $4,1 \%$ a frases nominales.

24. Las frecuencias de uso de las formas mixtas guardan una estrecha relación con las actitudes asumidas con respecto al discurso directo. Ello es así porque el $68,6 \%$ de los encabezados de este tipo corresponde a testimonios de hibridación local, que, en todos los casos recogidos, incorpora secuencias en

${ }^{6}$ Leech y Short 1981: 323. 
discurso directo (si se añaden los testimonios de hibridación global que contienen retransmisiones directas, la proporción asciende al 73,7\%).

24.1. De este modo, el comportamiento 1 resulta en general más favorable para las formas mixtas que el comportamiento 2: las más elevadas incidencias de formas mixtas se observan en El Mercurio, Clarín y El País, pertenecientes al grupo del comportamiento 1, y las más bajas, en La Opinión, La Nación y El Comercio, que exhiben el comportamiento 2. Las variaciones encuentran explicación en altas proporciones de uso de hibridación global (Hoy), o bien en pruritos de corrección fomentados por ortografías, gramáticas de intención normativa, manuales de redacción periodística y libros de estilo, que tienden a censurar las casi siempre mayoritarias construcciones con hibridación local (El Nacional, El Tiempo y El Universal).

24.2. Las más altas asiduidades de hibridación local se presentaron en los diarios El País, La Opinión, El Universal, La Nación, El Tiempo, El Mercurio y Clarín (no se registraron casos de hibridación global en El País, La Opinión y El Tiempo). Mayores frecuencias de hibridación global que de local se atestiguaron en Hoy y El Comercio (sin registros de hibridación local este último). El periódico El Nacional registró, por último, idénticas proporciones de hibridación local y global.

25. Si bien existe una tendencia general y hay ciertos comportamientos específicos de cada periódico, es obvio que la elección de una u otra forma de describir un acto discursivo ajeno obedece también a muchos otros factores, que deben analizarse en función de casos concretos. Razón tiene Ducrot ${ }^{7}$ cuando advierte que la lengua da una aprehensión enunciativa del mundo por cuanto la representación de la realidad pasa por el establecimiento previo de una serie de relaciones intersubjetivas dentro del discurso.

\footnotetext{
${ }^{7}$ Ducrot (1995) 1998: 124.
} 
26. De acuerdo con esta postura, son determinantes en la codificación lingüística de los titulares los aspectos semántico-pragmático-discursivos, tradicionalmente ignorados por los especialistas. También resultan pertinentes, luego entonces, en la adecuada descripción de estos productos verbales. Con fundamento en ello se desprenden las observaciones siguientes.

26.1. Existe una doble escala en los procesos lingüísticos del discurso ajeno. Con relación a las palabras de Loc 2, las modalidades discursivas aquí estudiadas se diferencian gradualmente según sus propiedades miméticodiegéticas y apropiativo-atributivas.

26.1.1. En lo concerniente al nivel instaurado por el continuum que establece la díada mímesis-diégesis, definitorio de las variedades generales, la variedad más mimética es, desde luego, el discurso directo, y la más diegética, el discurso narrado. El discurso indirecto ocupa una posición intermedia. Las distintas sub-variedades, así como las formas mixtas, representan estadios diversos de este continuo.

26.1.2. La segunda escala, que se instaura en el proceso de atribuciónapropiación de la palabra ajena, opone las formas marcadas y las no marcadas. En principio, las marcadas comportan un distanciamiento de Loc 1 con relación a Loc 2 o bien a la forma o al contenido de su enunciado, y las no marcadas, una adhesión de Loc 1 con respecto al punto de vista de Loc 2.

26.1.3. Las formas mixtas se ubican en diferentes puntos intermedios de la doble escala. Los testimonios de hibridación local suponen siempre la interrupción de una secuencia más o menos diegética para adoptar una actitud mimética explícita no apropiativa que revela la existencia de una heteroglosia discursiva. En la hibridación global, por el contrario, hay siempre una transición completa que modifica total o parcialmente los atributos miméticodiegéticos y apropiativo-atributivos del segmento inicial. 
26.1.4. Con todo, el proceso no puede reducirse solamente a esto: como bien se sabe, son muchos más los factores que determinan el sentido de los enunciados.

26.2. Según sea su ubicación en la doble escala, las variedades del discurso ajeno permiten una diversificación en el estatuto de la importancia asignada a Loc 2 o a sus palabras, independientemente de los comportamientos asumidos por los diarios.

26.2.1. A mayor mímesis, mayor protagonismo asignado a las palabras ajenas. En general, Loc 1 asume o presenta como más importantes las palabras de Loc 2 -y por consiguiente más dignas de destacarse - a medida que las retransmite de manera más mimética, y menos importantes si alude a ellas de modo más diegético. Así, por ejemplo, el discurso directo da mayor prominencia a las palabras de Loc 2 que el discurso narrado: mientras que el primero goza de una interpretación convencional de supuesto respeto a la forma y el contenido del enunciado original —además de que a menudo aísla las palabras ajenas - en el en discurso narrado Loc 1 alude al acto de habla de Loc 2 de manera global, sintética e integrada, sin detenerse, necesariamente, a expresar el contenido o la forma de las palabras ajenas (resulta ideal, pues, para aludir a declaraciones que se consideran poco relevantes o que se desea disimular o marginar).

26.2.2. A mayor apropiación, mayor credibilidad o importancia atribuida a Loc 2. En principio, Loc 1 asume o presenta a Loc 2 como una entidad más importante o confiable en la medida en que se apropia de las palabras ajenas sin atribuirlas a su origen. Salvo en casos de ironía, las formas no marcadas suponen una apropiación de las palabras ajenas tendente a la adhesión de Loc 1 al punto de vista asumido por Loc 2; la atribución, por el contrario, comporta un distanciamiento de Loc 1 con respecto a Loc 2 y su enunciado. 
26.3. Existe cierta propensión al aligeramiento de marcas. Parece que el discurso de los titulares exige, hasta cierto punto, el empobrecimiento de la marcación del discurso ajeno, como muestra la elevada incidencia de formas no marcadas y la existencia de marcas de escaso peso formal, como los morfemas del condicional con valor de potencial citativo o la sola presencia de verbo o conjunción subordinante, o las distintas manifestaciones del discurso directo marcado sin comillas. Amén de a la las evidentes exigencias de economía lingüística, esta situación parece obedecer, en algunos casos, a la necesidad, ideológicamente condicionada, de reducir la distancia establecida por los mecanismos de atribución, a fin de que Loc 1 se apropie de las palabras ajenas, ya sea con la intención de asumir o no el punto de vista con el que Loc 2 se identifica.

26.4. La marcación doble del discurso directo es motivada por la necesidad de reforzar las cualidades miméticas no apropiativas y, claro está, por la búsqueda del prestigio social asociado a una tradición ortográfica. Las marcas ortográficas de constituyentes, tanto en el discurso directo como en las formas mixtas con hibridación local, suelen emplearse para manifestar una discordancia con el punto de vista asumido por Loc 2 o bien para indicar usos que Loc 1 considera populares, impropios o no ejemplares. En cualquier caso, la reiteración de la actitud mimética es muestra del estatuto de mera suposición asignado al significado de retransmisión literal que se asocia de manera convencional al discurso directo.

26.5. Habida cuenta del conjunto de posibilidades de que dispone Loc 1 para describir un acto verbal, la elección de determinada variedad del discurso ajeno, y no otra, debe considerarse significativa. Esta elección obedece a estrategias discursivas motivadas por patrones ideológicos que comparten Loc 1 y la empresa periodística: ¿por qué destacar una parte del discurso y no otra?, ¿por qué reformular las palabras ajenas en unos casos y presentarlas 
como retransmisiones directas en otros?, ¿por qué omitir en algunas ocasiones el contenido de las palabras ajenas, el modo en que fueron expresadas o el agente del proceso verbal?, ¿por qué apropiarse totalmente de las palabras ajenas en unos titulares y en otros atribuirlas escrupulosamente?, ¿por qué expresar reservas con respecto al contenido de unos enunciados ajenos y no a otros?, ¿por qué insistir solo en ciertos casos en la literalidad de un segmento del enunciado ajeno?, ¿por qué los diarios utilizan distintos verbos de habla en los titulares de idénticos despachos de agencia? Recuérdese que el periodismo es, en realidad, un aparato técnico de difusión y legitimación de ideologías, y que en la redacción de los titulares interviene el personal de más alto rango del medio (es decir, el más interesado en la difusión de esas posturas).

26.6. A pesar de las conocidas pretensiones de objetividad manifiestas en el meta-discurso periodístico, el uso de las diversas modalidades del discurso ajeno en los titulares obedece de hecho a una estrategia persuasiva de Loc 1 , que puede develarse si se analiza el sentido del texto. La estrategia es diferente en cada caso: depende de la forma y el contenido de las palabras de Loc 2, así como de las situaciones de enunciación originaria y actualizadora, comprensivas, naturalmente, de las intenciones e ideologías subyacentes de la organización informativa y de Loc 1 y Loc 2.

26.7. Además, los titulares ofrecen una orientación argumentativa por medio de la elección de ciertos argumentos que se retienen prioritariamente y que conducen a un determinado tipo de conclusiones; mediante elecciones léxicas con un determinado peso argumentativo; por medio de información presupuesta; gracias a la construcción de un éthos discursivo; con la estructuración de discursos bivocales de orientación múltiple, y mediante segmentos discursivos insertos en contextos tendenciosos. 
27. Queda pendiente la validación del modelo general para otros usos discursivos, así como las comparaciones con los procedimientos específicos del discurso ajeno en otras lenguas y tradiciones periodísticas. Es necesario dilucidar, asimismo, las diferencias que existen entre los titulares aquí estudiados y los que se publican para encabezar otros géneros periodísticos, los que se publican en otros países, en la prensa sensacionalista y en el periodismo digital. Estudio aparte merecen también los cambios que, a lo largo de los años, ha experimentado el discurso ajeno en los titulares periodísticos. 


\section{BIBLIOGRAFÍA}

ABC. 2001. Libro de estilo de ABC. 2. ${ }^{\mathrm{a}}$ ed. A. M. Vigara (redactora). Barcelona: Ariel-Abc (Ariel Lingüística).

Alarcos LloraCH, Emilio. 1977. "Lenguaje de los titulares", en Lenguaje en periodismo escrito, F. Lázaro Carreter (ed.). Madrid: Fundación Juan March: (Serie Universitaria, 37)125-148. . (1994) 1999. Gramática de la lengua española. Madrid: Espasa Calpe-Real Academia Española (Nebrija y Bello).

AlCAIDE LARA, Esperanza Rocío. 1991. "Tópico, tema y rema: la estructura informativa en los titulares periodísticos", Philologia Hispalensis, 6 (1): 269-283.

. 2001. "La impersonalidad en los medios de comunicación", en Indagaciones sobre la lengua. Estudios de Filología y Lingüística Españolas en memoria de Emilio Alarcos, E. Méndez, Y. Congosto y J. Mendoza (eds.). Sevilla: Universidad de Sevilla: 289-322.

Alcina Franch, Juan y José Manuel Blecua. (1975) 2001. Gramática española. 11. ${ }^{a}$ ed. Barcelona: Ariel (Letras e Ideas).

Alcob A RuEd A, Santiago. 1983. "El presente en los titulares de prensa: no deíctico, pro-tiempo anafórico", Anàlisi, 7-8: 107-121.

- 1984. "Semiótica del tiempo en los titulares del enunciado periodístico", en Teoría semiótica. Actas del Congreso Internacional sobre Semiótica e Hispanismo, vol. 1, M. Á. Garrido Gallardo (ed.). Madrid: CSIC: 225-234.

Alonso, Amado y Pedro Henríquez Ureña. 1939. Gramática castellana. Segundo curso. Buenos Aires: Losada.

Alvar, Manuel. 1990. "Medios de comunicación y lingüística”, Lingüística Española Actual, 12 (2): 151-173.

Alvar, Manuel y Bernard Pottier. 1983. Morfología histórica del español. Madrid: Gredos (Biblioteca Románica Hispánica, III: Manuales, 57).

Amossy, Ruth. 1999. "L'ethos au carrefour des disciplines: réthorique, pragmatique, sociologie des champs", en Images de soi dans le discours. La construction de l'ethos, R. Amossy (ed.). Lausanne: Delachaux et Niestlé: 127-154.

AnsCOMBRE, Jean-Claude y Oswald Ducrot. 1983. L'argumentation dans la langue. Bruxelles: Pierre Mardaga.

AP. $C f$. The Associated Press.

Armentia Vizuete, José Ignacio y José María Caminos Marcet. 1998. La información: redacción y estructuras. Guipúzcoa: Universidad del País Vasco.

. 2003. Fundamentos de periodismo impreso. Barcelona: Ariel (Ariel Comunicación).

Austin, John Langshaw. (1962) 1971. Cómo hacer cosas con palabras. Trad. Genaro R. Carrió y Eduardo A. Rabossi. Buenos Aires: Paidós. 
AuthiER, Jacqueline. 1981. "Paroles tenues à distance", en Matérialités discursives, B. Conein, et al (eds.). Lille: Presses Universitaires de Lille.

. 1984. "Hétérogénéité(s) énonciative(s)", Langages, 73: 98-111.

AuthIER, Jacqueline y André Meunier. 1977. "Exercices de grammaire et discours rapporté", Langue Française, 33: 41-67.

ÁvilA, Raúl. 2006. De la imprenta a la internet: la lengua española y los medios de comunicación masiva. México: El Colegio de México (Jornadas, 148).

BÁez de Aguilar GonzÁlez, Francisco. 2002. Variaciones léxicas y morfosintácticas en el español de la prensa mexicana. Málaga: Universidad de Málaga (Textos Mínimos, 64).

B AJtín, Mijaíl Mijáilovich. (1935) 1986. "La palabra en la novela", en Problemas literarios y estéticos. Trad. Alfredo Caballero. La Habana: Arte y Literatura: 83-268.

. (1963) 1986. Problemas de la poética de Dostoievski. Trad. Tatiana Bubnova. México: FCE (Breviarios, 417).

B AL, Mieke. (1978) 1990. Teoría de la narrativa (Una introducción a la narratología). Trad. Javier Franco, 3. ${ }^{\mathrm{a}}$ ed. Madrid: Cátedra (Crítica y Estudios Literarios).

- 1981. "Notes on Narrative Embedding", Poetics Today, 2 (2): 41-59.

BALLY, Charles. 1912. "Le style indirect libre en français moderne", Germanisch-Romanische Monatsschrift, 4: 549-556, 597-606.

B ANFIELD, Ann. 1973. "Narrative Style and the Grammar of Direct and Indirect Speech", Foundations of Language, 10 (1): 1-39.

- (1982) 1995. Phrases sans parole: théorie du récit et du style indirect libre. Trad. Cyril Veken. Paris: Seuil.

BARAlt, Rafael María. 1945. Diccionario de galicismos. Buenos Aires: Joaquín Gil.

BARRigA VillanueVA, Rebeca. 1997. "Por las veredas de la incertidumbre. El uso del pospretérito en un periódico mexicano", Anuario de Letras, 35: 103-122.

BARTHES, Roland. 1966. "Introduction à l'analyse structural des récits", Communications, 8: 1-27.

Bastenier, Miguel Ángel. 2001. El blanco móvil. Curso de periodismo. México: Aguilar-Ediciones El País.

B A Ynham, Mike. 1996. "Direct speech: What's it doing in non-narrative discourse?", Journal of Pragmatics, 25 (1): 61-81.

Beltrán Almería, Luis. 1990. El discurso ajeno: panorama crítico. Zaragoza: Universidad de Zaragoza.

- 1992. Palabras transparentes. La configuración del discurso del personaje en la novela. Madrid: Cátedra (Crítica y Estudios Literarios).

BELl, Allan. 1991. The Language of the News Media. Oxford: Blackwell.

BELlo, Andrés. (1847) 1958. Gramática de la lengua castellana. Buenos Aires: Sopena. 
BEnAVEnt PAYÁ, Elisa. 2003. “¿Por qué contamos nuestras historias cotidianas en estilo directo?", Foro Hispánico, 23: 11-20.

Benveniste, Émile. (1966) 2001. Problemas de lingüística general I. Trad. Juan Almela, 21. ${ }^{a}$ ed. México: Siglo XXI (Lingüística).

. (1974) 2002. Problemas de lingüística general II. Trad. Juan Almela, 16. ${ }^{\mathrm{a}}$ ed. México: Siglo XXI (Lingüística).

Bond, Frank Fraser. 1996. Introducción al periodismo. Estudio del cuarto poder en todas sus formas. Trad. José Silva L. México: Limusa.

BosQUE, Ignacio. 1990. "Las bases gramaticales de la alternancia modal. Repaso y balance", en Indicativo y subjuntivo, I. Bosque (ed.). Madrid: Taurus Universitaria (Gramática del Español, 1): 13-65.

BRECHT, Richard. D. 1974. "Deixis in Embedded Structures", Foundations of Language, 11 (4): 489-518.

BRIZ GÓmEZ, Antonio (coord.). 1995. La conversación coloquial. Materiales para su estudio. Valencia: Universitat de València (Cuadernos de Filología, anejo XVI).

Brown, Gillian y George Yule. (1983) 1993. Análisis del discurso. Trad. Silvia Iglesias. Madrid: Visor.

BRUÑA CUEVAS, Manuel. 1990. "Sobre la reproducción del discurso", Philologia Hispalensis, 5 (1): 83-110.

. 1993. "El discurso indirecto en periódicos franceses y españoles", en Estudios pragmáticos: lenguaje y medios de comunicación, Grupo Andaluz de Pragmática (ed.). Sevilla: Universidad de Sevilla: 37-79.

Bruña Cuevas, Manuel y María Muñoz Romero. 1992. "Caracterisation syntactico-énonciative des trois modes du discours rapporté", Philologia Hispalensis, 7-1: 226-243.

BüHLER, Karl. (1934) 1961. Teoría del lenguaje. Trad. Julián Marías, 2. ${ }^{a}$ ed. Madrid: Revista de Occidente.

B URniston, Christabel y John Parry. 1987. Direct Speech. London: Hodder and Stoughton.

Calvimontes, Jorge. 1994. El periódico. 4. a ed. México: Trillas.

CAMERON, Richard. 1998. "A variable syntax of speech, gesture and sound effect: Direct quotations in Spanish", Language Variation and Change, 10: 43-83.

CANGA LAREQUi, Jesús. 1994. El diseño periodístico en prensa. Barcelona: Bosch.

CANO AgUILAR, Rafael. 1981. Estructuras sintácticas transitivas en el español actual. Madrid: Gredos (Biblioteca Románica Hispánica, II: Estudios y Ensayos, 310).

- 1999. "Los complementos de régimen verbal", en Gramática descriptiva de la lengua española, vol. 2: Las construcciones sintácticas fundamentales, Relaciones temporales, aspectuales y modales, I. Bosque y V. Demonte (eds.). Madrid: Espasa Calpe-Real Academia Española-Fundación José Ortega y Gasset (Nebrija y Bello): 1807-1854. 
CAppelen, Herman y Ernie Lepore. 1997. "Varieties of Quotation", Mind, 423: 429-450.

-. 2005. "Varieties of Quotation Revisited", Belgian Journal of Linguistics, 17: 51-75.

CASAdo VELARDE, Manuel. 1978. "La transformación nominal, un rasgo de estilo de la lengua periodística", Cuadernos de Investigación Filológica, 4 (1): 101-112.

- 1984. "Semiótica de los titulares: pautas para el análisis de los titulares periodísticos", en Teoría semiótica. Actas del Congreso Internacional sobre Semiótica e Hispanismo, vol. 1, M. Á. Garrido Gallardo (ed.). Madrid: CSIC: 235-242.

- 1986. "La supresión de nexos en los titulares de prensa: el tipo 'las relaciones Londres-Dublín'”, Archivum, 38: 223-228.

—. 1995. "El lenguaje de los medios de comunicación", en La lengua española, hoy, M. Seco y G. Salvador (eds.). Madrid: Fundación Juan March: 153-164.

CAS ASÚs, Josep María. 1988. Iniciación a la Periodística. Barcelona: Teide.

Castelli, Eugenio. 1981. Manual de periodismo. Teoría y técnica de la información. Buenos Aires: Plus Ultra.

CATACH, Nina. 1980. "La ponctuation”, Langue Française, 45 : 16-27.

CATE, Abraham. 1996. "Modality of Verb Forms in German Reported Speech", en Reported Speech, T. A. J. M. Janssen y W. van der Wurff (eds.). Amsterdam-Philadelphia: John Benjamins: 189-211.

Clarín. 1997. Manual de estilo. Diario “Clarín”. Buenos Aires: Aguilar.

ClARK, Herbert H. y Richard J. Gerrig. 1990. "Quotations as Demonstration", Language, 66 (4): 764-805.

Cohn, Dorrit. 1978. Transparent Minds: Narrative Modes for Presenting Consciousness in Fiction. Princeton: Princeton University Press.

Collins, Daniel E. 2001. Reanimated Voices: Speech Reporting in a Historical-Pragmatic Perspective. Amsterdam-Philadelphia: John Benjamins (Pragmatics \& Beyond, New Series, 85).

COMRIE, Bernard. 1976. "The Syntax of Action Nominals: A Cross-language Study", Lingua, 40: 177-201.

—. 1986. "Tense in Indirect Speech", Folia Linguistica, 20 (3): 265-296.

Coulmas, Florian. 1985. "Direct and Indirect Speech: General Problems and Problems of Japanese", Journal of Pragmatics, 9: 41-63.

- 1986. "Reported Speech: Some General Issues", en Direct and Indirect Speech, F. Coulmas (ed.). Berlin: Mouton de Gruyter (Trends in Lunguistics: Studies and Monographs, 31): 1-28.

- 1994. "Reported Speech", en The Encyclopedia of Language and Linguistics, vol. 7, R. E. Asher y J. M. Y. Simpson (eds.). Oxford: Pergamon Press: 3552-3554.

Cronkhite, Gary y Liska, Jo R. 1980. "The judgement of communicant acceptability”, en Persuasion, M. E. Roloff y J. R. Miller (eds.). Beverly Hills: Sage: 101-140. 
Cuervo, Rufino José. (1874) 1958. Notas a la Gramática de la lengua castellana de don Andrés Bello. Buenos Aires: Sopena.

. (1886) 1994. Diccionario de construcción y régimen de la lengua castellana. Bogotá: Instituto Caro y Cuervo.

CHAFE, Wallace. 1977. "The recall and verbalization of past experience", en Current Issues in Linguistic Theory, R. W. Cole (ed.). Bloomington: Indiana University Press: 215-246.

. 1986. "Evidentiality in English Conversation and Academic Writing", en Evidentiality: The Linguistic Coding Epistemology, W. Chafe y J. Nichols (eds.). Norwood, N. J.: Ablex: 261-273.

-1 1994. Discourse, Consciousness, and Time: The Flow and Displacement of Conscious Experience in Speaking and Writing. Chicago: University of Chicago Press.

CharaudeAu, Patrick. 1983. Langage et discours. Eléments de sémiolinguistique (théorie et pratique). Paris: Hachette. - (1997) 2003. El discurso de la información. Trad Margarita Mizraji. Barcelona: Gedisa (El Mamífero Parlante).

Chatman, Seymour. (1978) 1990. Historia y discurso. Trad. María Jesús Fernández Prieto. Madrid: Taurus (Taurus Humanidades).

CHomsk Y, Noam. 1957. Syntactic Structures. The Hague: Mouton.

- 1970. "Remarks on Nominalization", en Readings in English Transformational Grammar, R. Jacobs y P. Rosenbaum (eds.). Waltham: Ginn: 184-221.

DA VIDSON, Donald. 1968. “On Saying That”, Synthese, 19: 130-146.

_. (1979) 1984. "Quotation”, en Inquires Into Truth and Interpretation. Oxford: Oxford University Press: 79-92.

De Gregorio, Domenico. (1960) 1966. Metodología del periodismo. Trad. José María Desantes. Madrid: Ediciones Rialp.

DEHENNIN, Elsa. 1994. "El discurso indirecto libre $(D I L)$ en la encrucijada de discursos", en Actas del XI Congreso de la Asociación Internacional de Hispanistas, vol. I, J. Villegas (ed.). Irvine, USA: University of California: 114-123.

DelbecQue, Nicole y Béatrice Lamiroy. 1999. "La subordinación sustantiva: las subordinadas enunciativas en los complementos verbales", en Gramática descriptiva de la lengua española, vol. 2: Las construcciones sintácticas fundamentales, Relaciones temporales, aspectuales y modales, I. Bosque y V. Demonte (eds.). Madrid: Espasa Calpe-Real Academia Española-Fundación José Ortega y Gasset (Nebrija y Bello): 1967-2081.

Di Bello, Hernán y Matías Antonio Sapegno. 2003. 30 líneas: una guía para pensar y escribir en las agencias de noticias. Buenos Aires: De la Travesía.

Dobre, Dan. 1999. Préliminaires à une sémiotique de la presse: le quotidien. Bucureşti: Editura Universsităţii din Bucureşti.

DoR, Daniel. 2003. "On newspaper headlines as relevance optimizers", Journal of Pragmatics, 35: 695-721. 
DUBSKÝ, Josef y Thelvia Heredia Vedey. 1977. "Los titulares discursivos en la prensa cubana”, Ibero-Americana Pragensia, 11: 31-38.

DuCRot, Oswald. (1972) 1982. Decir y no decir. Trad. Walter Minetto y Amparo Hurtado. Barcelona: Anagrama (Biblioteca de Lingüística, 2). 1980. Les échelles argumentatives. Paris: Minuit.

. (1984) 1986. El decir y lo dicho. Trad. Irene Agoff. Barcelona: Paidós (Paidós Comunicación, 24).

- (1995) 1998. "Componentes de la descripción lingüística", en Nuevo diccionario enciclopédico de las ciencias del lenguaje, O. Ducrot y J. M. Shaeffer (eds.). Trad. María Camino Girón, Teresa María Rodríguez y Marta Tordesillas. Madrid: Arrecife: 109-125.

ECO, Umberto. 1977. "Guida all'ipretazione del linguagio giornalistico", en La lingua italiana oggi: un problema scolastico e sociale, L. Renzi y M. A. Cortelazzo (eds.). Bologna: Società editrice il Mulino (Problemi e prospective. Serie di linguistica e critica litteraria): 165-187.

El Mundo. 1996. Libro de estilo. V. de la Serna (coord.). Madrid: Unidad Editorial-Temas de Hoy.

El PAÍs. 2003. Libro de estilo. 18. a ed. Madrid: Ediciones El País.

El PERIÓDiCO. 1989. Libro de estilo de El Periódico. Barcelona: Editorial Primera Plana.

El Tiempo. 1995. Manual de redacción. Bogotá: El Tiempo.

El Univers AL. 2004. Guía de estilo. México: El Universal.

EMIG, Elmer. 1927. "The Connotation of Newspaper Headlines", Journalism Quarterly, 4 (4): 53-59.

ENGWALL, Lars. 1978. Newspapers as Organizations. Farmborough, U.K.: Grower.

Epstein, Edward Jay. 1973. News from Nowhere. New York: Random House.

ESCRIBANO HERnÁNDEZ, Asunción. 2001. Uso periodístico de la lengua: los titulares en prensa. Salamanca: Universidad de Salamanca (Vítor, 64).

- 2006. Comentario de textos periodísticos: informativos, interpretativos y de opinión. Salamanca: Universidad de Salamanca.

- 2007. "El discurso reproducido en las informaciones electorales", Anàlisi, 35: 65-82.

FAIRClOUGH, Norman. 1988. "Discourse Representation in Media Discourse", Sociolinguistics, 17 (2): 125-139.

1995a. Critical Discourse Analysis. London: Longman. . 1995b. Media Discourse. London: Edward Arnold.

FAIRClOUGH, Norman y Ruth Wodak. (1997) 2000. "Análisis crítico del discurso", en El discurso como interacción social. Estudios del discurso: introducción multidisciplinaria, vol. 2, T. A. van Dijk (ed.). Trad. Elena Marengo. Barcelona: Gedisa (Lingüística y Análisis del Discurso): 367-404. 
FERnÁndez BEAUMONT, José. 1987. El lenguaje del periodismo moderno. Los libros de estilo en la prensa. Madrid: Sociedad General Española de Librería.

Fernández Lagunilla, Marina y Covadonga Pendones. 1993. "Recursos polifónicos del narrador en el discurso periodístico", Revista de Filología Románica, 10: 285-294.

- 1997. "Discurso reproducido y juegos de palabras en los títulos de prensa", Discurso, 21-22: 77-102.

FERNÁNDEZ LópeZ, María del Carmen. 1999. Las preposiciones. Valores y usos. Construcciones preposicionales. Salamanca: Ediciones Colegio de España (Español Lengua Extranjera, 13).

FERnÁndez Soriano, Olga y Susana Táboas Baylín. 1999. "Construcciones impersonales no reflejas", en Gramática descriptiva de la lengua española, vol. 2: Las construcciones sintácticas fundamentales, Relaciones temporales, aspectuales y modales, I. Bosque y V. Demonte (eds.). Madrid: Espasa Calpe-Real Academia Española-Fundación José Ortega y Gasset (Nebrija y Bello): 17231778.

FILlmore, Charles. 1968. "The Case for Case", en Universals in Linguistic Theory, E. Bach y R. T. Haims (eds.). New York: Holt, Rinehart \& Winston: 1-51.

- 1982. "Frame Semantics", Linguistics in the Morning Calm. Selected Papers from SICOL-1981, The Linguistic Society of Korea (ed.). Seoul: Hanshing Publishing Company.

FónAGY, Ivan. 1986. "Reported Speech in French and Hungarian”, en Direct and Indirect Speech, F. Coulmas (ed.). Berlin: Mouton de Gruyter (Trends in Lunguistics: Studies and Monographs, 31): 255-309.

Fontanillo, Enrique y M. Isabel Riesco. 1990. Teleperversión de la lengua. Barcelona: Anthropos (Conciencia y Libertad, 9).

FontCuberta, Mar. 1981. "Fuentes de la noticia: identificación y atribución", en Estructura de la noticia periodística. 2. a ed. Barcelona: A.T.E. (Textos de Periodismo): 83-102.

. 1993. La noticia. Pistas para percibir el mundo. Barcelona: Paidós (Papeles de Comunicación, 1).

FONTE, Irene. 1996a. "El discurso periodístico: un ejemplo de polifonía", en Tercer Encuentro de Lingüística del Noroeste, vol. 3: Interdisciplinas lingüísticas, Z. Estrada, M. Figueroa y G. López (eds.). Hermosillo, México: Universidad de Sonora: 145-158.

- 1996b. "Funciones del discurso reportado en la prensa", en El significado de la diversidad lingüística y cultural, $\mathrm{H}$. Muñoz y P. Lewin (eds.). México: UAM-Iztapalapa-INAH (Investigaciones Lingüísticas, 2): 213-221.

. 1996c. "Las formas narrativizadas del discurso reportado en la prensa", en Español y lenguas indoamericanas: estudios $y$ aplicaciones, H. Muñoz Cruz (ed.). México: UAM-Iztapalapa (Investigaciones Lingüísticas, 3): 41-57. 
1998. Cuba 1906-1921: versiones de la nación en el discurso periodístico. México: El Colegio de México (Tesis).

—. 1999. "La construcción de una escena enunciativa en el discurso periodístico", Signos Literarios y Lingüísticos, 1 (1): 142-151.

- 2002. La nación cubana y Estados Unidos: un estudio del discurso periodístico (1906-1921). México: El Colegio de México-UAMIztapalapa (Estudios de Lingüística y Literatura, 45).

FOWLER, Roger. 1986. Linguistic Criticism. Oxford: Oxford University Press.

- 1991. Language in the News. Discourse and Ideology in the Press. London: Routledge.

FRANCESCUTTI, Luis Pablo. 2009. "El tiempo de los titulares. Un análisis verbal de la titulación en la prensa española durante el periodo 1980/2005", Estudios sobre el Mensaje Periodístico, 15: 243-259.

FUller, Jack. 1996. News Values. Ideas for an Information Age. Chicago: University of Chicago Press.

Gaillard, Philippe. 1972. Técnica del periodismo. Trad. Eduard Pons. Barcelona: Oikos-Tau (¿Qué Sé?, 77).

GARCÍA NúÑEZ, Fernando. 1985. Cómo escribir para la prensa. Madrid: Ibérico Europea de Ediciones.

GARST, Robert E. y Theodore Menline Bernstein. 1940. Headlines and Deadlines. A Manual for Copyeditors. 2. ${ }^{\mathrm{a}}$ ed. New York: Columbia University Press.

Genette, Gérard. 1966. "Frontières du récit", Communications, 8: 152-163. - (1972) 1989. Figuras III. Trad. Carlos Manzano. Barcelona: Lumen (Palabra Crítica).

. (1987) 2001. Umbrales. Trad. Susana Lage. México: Siglo XXI.

. (1993) 1998. Nuevo discurso del relato. Trad. Marisa Rodríguez Tapia. Madrid: Cátedra (Crítica y Estudios Literarios).

Georga Kopoulou, Alexandra. 1997. Narrative Performances: A Study of Modern Greek Storytelling. Amsterdam-Philadelphia: John Benjamins.

Gili GAYA, Samuel. 1967. Curso superior de sintaxis española. 9. ${ }^{a}$ ed. Barcelona: Bibliograf.

Girón AlCONCHEL, José Luis. 1989. Las formas del discurso referido en el "Cantar de mio Cid”. Madrid: Real Academia Española (Boletín de la Real Academia Española, anejo XLIV).

. 1992. "Subordinación sustantiva y discurso indirecto en la prosa medieval", en Estudios filológicos en homenaje a Eugenio de Bustos Tovar, J. A. Bartol et al (eds.). Salamanca: Universidad de Salamanca: 363-377.

. 1993. Introducción a la explicación lingüística de textos. Metodología y práctica de comentarios lingüísticos. 3. a ed. Madrid: Edinumen (Iniciación Universitaria).

- 2006. "Sobre la gramaticalización del discurso referido", en El español en América. Diatopía, diacronía e historiografía. Homenaje a José G. Moreno de Alba en su 65 aniversario, C. Company (ed.). 
México: Universidad Nacional Autónoma de México (Ediciones Especiales, 39): 395-406.

Givón, Talmy. 1995. Functionalism and Grammar. AmsterdamPhiladelphia: John Benjamins.

Goldberg, Adele E. 1995. Constructions: A Construction Grammar Approach to Argument Structure. Chicago: University of Chicago Press.

Gómez Mompart, José Luis. 1982. Los titulares en prensa. Barcelona: Mitre.

Gómez SÁnCHEZ, María Elena. 2008. “CCómo lo cuentan allá? Análisis de un conjunto de titulares de la prensa española y americana”, Español Actual, 89: 39-55.

Gómez TORRego, Leonardo. 1997. Manual de español correcto, vol. 2: Morfología y sintaxis. 8. ${ }^{\mathrm{a}}$ ed. Madrid: Arco Libros.

. 2002. Gramática didáctica del español. 8. ${ }^{a}$ ed. Madrid: Ediciones SM.

Gomis, Lorenzo. 1989. Teoria dels gèneres periodístics. Barcelona: Centre d'Investigació de la Comunicació, Generalitat de Catalunya.

. 1991. Teoría del periodismo: cómo se forma el presente. México: Paidós Mexicana (Paidós Comunicación, 44).

GRICE, Herbert Paul 1975. "Logic and conversation", en Syntax and Semantics 3: Speech Acts, P. Cole y J. L. Morgan (eds.). New York: Academic Press.

Grijelmo, Álex. 2003. El estilo del periodista. México: Taurus (Pensamiento).

Grupo Milenio. 2005. Manual Milenio Diario. México: Grupo Milenio.

GRUPO $\mu$. (1982) 1987. Retórica general. Trad. Juan Victorio. Barcelona: Paidós (Paidós Comunicación, 27).

GuÍzAR GARCÍA, Elizabeth Fabiola. 2004. El uso de los verbos en los titulares de cinco diarios de la ciudad de México: análisis sintáctico. México: Universidad Nacional Autónoma de México (tesis).

- 2007. Los titulares en la prensa mexicana del siglo XX. Estudio del diario El Universal. México: Universidad Nacional Autónoma de México (tesis).

Guntern WeIBEL, Elba. 2000. "Los titulares hablan", en Lengua, discurso, texto (I Simposio Internacional de Análisis del Discurso), vol. II, J. J. de Bustos Tovar, P. Charaudeau, J. L. Girón Alconchel et al. (eds.) Madrid: Visor Libros: 1951-1960.

Gutiérrez Ordóñez, Salvador. 1986. "Observaciones sobre el estilo directo en español”, Estudios Humanísticos. Filología, 8: 23-38.

. 1997. Principios de sintaxis funcional. Madrid: Arco Libros (Bibliotheca Philologica).

- 2000. Temas, remas, focos, tópicos y comentarios. 2. ${ }^{\mathrm{a}}$ ed. Madrid: Arco Libros (Cuadernos de Lengua Española, 46). 
HABERland, Hartmut. 1986. "Reported Speech in Danish", en Direct and Indirect Speech, F. Coulmas (ed.). Berlin: Mouton de Gruyter (Trends in Lunguistics: Studies and Monographs, 31): 219-253.

HallidAy, Michael Alexander Kirkwood. 1994. An Introduction to Functional Grammar. 2. ${ }^{\mathrm{a}}$ ed. London: Edward Arnold.

HAND, Michael. 1991. "On Saying That Again”, Linguistics and Philosophy, 14: 349-365.

HAVERKATE, Henk. 1996. "Modal Patterns of Direct and Indirect Discourse in Peninsular Spanish", en Reported Speech, T. A. J. M. Janssen y W. van der Wurff (eds.). Amsterdam-Philadelphia: John Benjamins: 97119.

Heredia Vedey, Thelvia. 1986. "Acerca del orden de palabras en los titulares de las noticias de la prensa plana cubana", Anuario de Artes y Letras, 3-4: 282-290.

HERnÁndez R., Rafael. 1990. El lenguaje de los periodistas 1. Guadalajara, México: Editorial Ágata.

HERnÁndeZ, Humberto. 2004. El mensaje en los medios (a propósito del estudio lingüístico de la prensa regional canaria). Madrid-Frankfurt: Iberoamericana-Vervuert (Lingüística Iberoamericana, 25).

Hernando CuAdrado, Luis Alberto. 2000. El discurso periodístico. Madrid: Verbum (Español Práctico).

- 2002. "Sobre la configuración lingüística del mensaje periodístico", Estudios sobre el Mensaje Periodístico, 8: 261-274.

HernanZ, M. Lluïsa. 1999. "El infinitivo", en Gramática descriptiva de la lengua española, vol. 2: Las construcciones sintácticas fundamentales, Relaciones temporales, aspectuales y modales, I. Bosque y V. Demonte (eds.). Madrid: Espasa Calpe-Real Academia EspañolaFundación José Ortega y Gasset (Nebrija y Bello): 2197-2356.

Hickmann, Maya. 1993. "The Boundaries of Reported Speech in Narrative Discourse: Some Developmental Aspects", en Reflexive Language: Reported Speech and Metapragmatics, J. A. Lucy (ed.). Cambridge: Cambridge University Press.

HodGE, Robert y Gunther Kress. 1993. Language as Ideology. 2. a ed. New York: Routledge.

Hurtado GonzÁlez, Silvia. 2003. El uso del lenguaje en la prensa escrita. Valladolid: Universidad de Valladolid (Linguística y Filología, 56).

. 2009. "Algunas peculiaridades de los titulares de actos de habla en la prensa española e hispanoamericana”, Zer, 27: 189-202.

JAKOBSON, Roman. (1936-1963) 1981. Ensayos de lingüística general. Trad. Josep M. Pujol y Jem Cabanes, 2. ${ }^{a}$ ed. Barcelona: Seix Barral (Biblioteca Breve).

JAnsSEN, Theo A. J. M. y Wim van der Wurff. 1996. "Introductory Remarks on Reported Speech and Thought", en Reported Speech, T. A. J. M. Janssen y W. van der Wurff (eds.). Amsterdam-Philadelphia: John Benjamins: 1-12. 
JESPERSEN, Otto. (1924) 1968. La filosofía de la gramática. Trad. Carlos Manzano, 10. ${ }^{\mathrm{a}}$ ed. Barcelona: Anagrama (Argumentos, 30).

Johnson, Stanley y Julian Harriss. (1942) 1963. El reportero profesional. Trad. Guillermo Céspedes Rivera. México: Trillas.

KAB ATEK, Johannes. 2005. "Tradiciones discursivas y cambio lingüístico", Lexis, 29 (2): 151-177.

KAY, Paul. 1997. "Construction Grammar", en Words and the Grammar of Context. Stanford: Center for the Study of Language and Information.

Kerbrat-Orecchioni, Catherine. 1980. L'énonciation. De la subjectivité dans le langage. Paris: Librairie Armand Colin.

KoptJeVskAJA-T AMM, Maria. 1993. Nominalizations. London-New York: Routledge (Theoretical Linguistics).

KVAVIK, Karen H. 1986. "Characteristics of Direct and Reported Speech Prosody: Evidence from Spanish", en Direct and Indirect Speech, F. Coulmas (ed.). Berlin: Mouton de Gruyter (Trends in Lunguistics: Studies and Monographs, 31): 333-360.

LA VANGUARDiA. 1986. Libro de redacción de La Vanguardia. Barcelona: La Vanguardia-TIS A.

LAPESA, Rafael. 1963. "La lengua desde hace cuarenta años", Revista de Occidente, 8-9: 193-208.

. 1977. "Tendencias y problemas actuales de la lengua española", en Comunicación y lenguaje, R. Lapesa (ed.). Madrid: Karpós: 207-229.

LARA RAmos, Luis Fernando, et al. 2010. Diccionario del español de México, L. F. Lara (dir.). México: El Colegio de México.

LAZARD, Gilbert. 2001. "On the Grammaticalization of Evidentiality", Journal of Pragmatics, 33 (3): 359-367.

LÁzARO CARRETER, Fernando. (1976) 1998. "Vivir en 'cantaría"”, en El dardo en la palabra. Barcelona: Círculo de Lectores: 95-97.

. 1977. "El lenguaje periodístico, entre el literario, el administrativo y el vulgar", en Lenguaje en periodismo escrito, F. Lázaro Carreter (ed.). Madrid: Fundación Juan March: 7-32.

1980. Estudios de Lingüística. Barcelona: Crítica. . (1986) 1998. "Israel dispondría de la bomba atómica", en El dardo en la palabra. Barcelona: Círculo de Lectores: 384-387.

. 1990. "El idioma del periodismo, ¿lengua especial", en El idioma español en las agencias de prensa, P. García y A Gómez (eds.). Madrid-Salamanca: Fundación Germán Sánchez Ruipérez (Cultura y Comunicación, 1): 25-44.

LE BIDOIS, Georges y Robert Le Bidois. 1971. Syntaxe du français moderne. Ses fondements historiques et psychologiques. 2. ${ }^{\mathrm{a}}$ ed. Vols. I y II. Paris: Éditions Picard.

LEECH, Geoffrey N. 1983. Principles of Pragmatics. London: Longman.

LEECH, Geoffrey N. y Michael H. Short. 1981. Style in Fiction. A Linguistic Introduction to English Fictional Prose. New York: Longman (English Language, 13).

LENZ, Rodolfo. 1935. La oración y sus partes. 3. a ed. Madrid: Ávila. 
Levinson, Stephen C. (1983) 1989. Pragmática. Trad. África Rubiés Mirabet. Barcelona: Teide.

LI, Charles N. 1986. "Direct and indirect speech: A functional study", en Direct and Indirect Speech, F. Coulmas (ed.). Berlin: Mouton de Gruyter (Trends in Lunguistics: Studies and Monographs, 31): 29-45.

LiCHFIELD, Guideon. 2000. "La declarocracia en la prensa". Trad. Rosamaría Núñez. Letras Libres, 19: 54-58.

LIPS, Marguerite. 1926. Le style indirect libre. Paris: Payot.

LONGACRE, Robert E. 1994. "The Dynamics of Reported Dialogue in Narrative", Word, 45: 125-143.

LOPE BlANCH, Juan M. 1979. El concepto de oración en la lingüística española. México: Universidad Nacional Autónoma de México. (Cuadernos de Lingüística, 1).

- 1983. Análisis gramatical del discurso. México: Universidad Nacional Autónoma de México (Publicaciones del Centro de Lingüística Hispánica, 17).

López de ZuAzo Algar, Antonio. 1990. Diccionario del periodismo. 5. ed. Madrid: Ediciones Prámide.

López HidAlgo, Antonio. 2009. El titular: manual de titulación periodística. México: Alfaomega.

LÓPEZ PAN, Fernando. 2004. "El arte de las citas", en Redacción para periodistas: informar e interpretar, J. Cantavela y J. F. Serrano (eds.). Barcelona: Ariel (Ariel Comunicación): 203-224.

LUNA TRAILL, Elizabeth. 1980. Sintaxis de los verboides en el habla culta de la ciudad de México. México: Universidad Nacional Autónoma de México, 1980 (Publicaciones del Centro de Lingüística Hispánica, 8).

LyONS, John. (1995) 1997. Semántica lingüística. Una introducción. Trad. Santiago Alcoba Rueda. Barcelona: Paidós (Paidós Comunicación, 97).

MaCAulay, Ronald K. S. 1987. "Polyphonic Monologues: Quoted Direct Speech in Oral Narratives", Papers in Pragmatics, 1 (2): 1-34.

Maingueneau, Dominique. 1976. Initiation aux méthodes de l'analyse du discours. Paris: Hachette.

. 1981. Approche de l'énonciation en linguistique française. Paris: Hachette (Langue, Linguistique, Communication).

- 1999. "Ethos, scénographie, incorporation", en Images de soi dans le discours. La construction de l'ethos, R. Amossy (ed.). Lausanne: Delachaux et Niestlé: 75-100.

Maldonado, Concepción. 1991. Discurso directo y discurso indirecto. Madrid: Taurus Universitaria (Gramática del Español, 3).

-. 1999. "Discurso directo y discurso indirecto", en Gramática descriptiva de la lengua española, vol. 3: Entre la oración y el discurso, y Morfología, I. Bosque y V. Demonte (eds.). Madrid: Espasa Calpe-Real Academia Española-Fundación José Ortega y Gasset (Nebrija y Bello): 3549-3595.

MAPELli, Giovanna. 2005. "Los titulares de la crónica deportiva", Español Actual, 83: 89-106. 
MARín, Carlos. 2006. Manual de periodismo. México: Debolsillo.

Martín Vivaldi, Gonzalo. 1998. Géneros periodísticos. 6. ${ }^{a}$ ed. Madrid: Paraninfo.

2000. Curso de redacción. Teoría y práctica de la composición y del estilo. 33. a ed., actualizada por Arsenio Sánchez Pérez. Madrid: Paraninfo.

Martinell, Emma. 1978. "Un fenómeno lingüístico en los titulares de Cambio 16", Anuario de Filología, 4: 317-334.

Martínez Albertos, José Luis. 1990. "El uso de la lengua en la comunicación periodística”, Lingüística Española Actual, 12 (2): 175196.

2001. Curso general de redacción periodística. Lenguaje, estilos y géneros periodísticos en prensa, radio, televisión y cine. 5. ${ }^{\mathrm{a}}$ ed. Madrid: Paraninfo.

MARTÍnez DE SousA, José. 1981. Diccionario general del periodismo. Madrid: Paraninfo.

—. 1985. Diccionario de ortografía. Madrid: Ediciones Generales Anaya.

. 2004. Ortografía y ortotipografía del español actual. Gijón: Trea (Biblioteconomía y Administración Cultural, 95).

Martínez Hernando, Bernardino. 1990. Lenguaje de la prensa. Madrid: Eudema.

MARTínez MARÍn, Juan. 1993. "El lenguaje periodístico. Notas históricas y de caracterización”, Anuario de Lingüística Hispánica, 9: 137-149.

MARTínez RiverA, Eloi. 1994. Evolución del titular y el lead en los periódicos bilbaínos "El Liberal”, “La Gaceta del Norte” y "Euzkadi” (1901-1937). Leioa: Universidad del País Vasco.

Mathessius, Vilém. 1975. A Functional Analysis of Present Day English on a General Linguistic Basis, J. Vachek (ed.). Trad. L. Duskova. Prague: Academia.

Mathis, Terrie y George Yule. 1994. "Zero Quotatives”, Discourse Processes, 18: 63-76.

MAYES, Patricia. 1990. "Quotation in Spoken English", Studies in Language, 14 (2): 325-363.

MCHALE, Brian. 1978. "Free Indirect Discourse: A Survey of Recent Accounts", Poetics and the Theory of Literature, 3: 249-287.

MENCHER, Melvin. 1977. News reporting and writing. Dubuque, USA: Wm.Cm.Brown Company Publishers.

MÉndeZ GARCÍA DE PAREDES, Elena. 1999. “Análisis de la reproducción del discurso ajeno en los textos periodísticos", Pragmalingüística, 7: 99-128.

- 2000a. "La literalidad de la cita en los textos periodísticos", Revista Española de Lingüística, 30 (1): 147-163.

—. 2000b. "Análisis de las formas de introducir el discurso ajeno en los textos periodísticos: el contexto reproductor", en Lengua, discurso, texto (I Simposio Internacional de Análisis del Discurso), vol. II, J. J. 
de Bustos Tovar, P. Charaudeau, J. L. Girón Alconchel et al. (eds.) Madrid: Visor Libros: 2081-2098.

Milenio. $C f$. Grupo Milenio.

MirandA, José Alberto. 1994. La formación de palabras en español. Salamanca: Colegio de España.

Mitтwoch, Anita. 1985. "Sentences, utterance boundaries, personal deixis and the E-hypothesis", Theoretical Linguistics, 12: 137-152.

Moliner, María. 1975. Diccionario de uso del español. Madrid: Gredos (Biblioteca Románica Hispánica, v: Diccionarios, 5).

Moreno DE AlBA, José G. 1985. Valores de las formas verbales en el español de México. 2. ${ }^{a}$ ed. México: Universidad Nacional Autónoma de México (Publicaciones del Centro de Lingüística Hispánica, 7).

- 1996. "Notas sobre el concepto de prestigio aplicado a algunos diarios mexicanos y su relación con el diseño y los encabezamientos de sus primeras planas", Boletín del Instituto de Investigaciones Bibliográficas, 1 (1): 23-50.

. 2003. Estudios sobre los tiempos verbales. México: Universidad Nacional Autónoma de México (Publicaciones del Centro de Lingüística Hispánica, 50).

Munro, Pamela. 1982. "On the Transitivity of 'Say' Verbs", en Studies in Transitivity, P. J. Hopper y S. A. Thompson (eds.). New York: Academic Press (Syntax and Semantics, 15): 301-318.

Muñiz CHacón, Carmen. 1990. "Retórica en los titulares de prensa", en Investigaciones semióticas III. Actas del III Simposio Internacional de la Asociación Española de Semiótica, vol. II. Madrid: Universidad Nacional de Educación a Distancia: 215-222.

NEAL, Robert Miller. 1933. Newspaper Desk Work. New York: D. AppletonCentury.

NoH, Eun-Ju. 2000. Metarepresentation: A Relevance-theory Approach. Amsterdam-Philadelphia: John Benjamins (Pragmatics \& Beyond, New Series, 69).

NøLKE, Henning, Kjersti Fløttum y Coco Norén. 2004. ScaPoLine. La théorie Scandinave de la polyphonie linguistique. Paris: Kimé.

NunberG, Geoffrey. 1990. The Linguistics of Punctuation. Stanford: Center for the Study of Language and Information (Lecture Notes, 18).

NúÑez LAdEvÉZE, Luis. 1979. El lenguaje de los media. Madrid: Pirámide.

—. 1991. "El título periodístico informativo", en Manual para periodismo. Barcelona: Ariel: 219-241.

- 1995. Introducción al periodismo escrito. Barcelona: Ariel (Ariel Comunicación).

PAGE, Norman. 1973. Speech in the English Novel. London: Macmillan Press.

PALMER, Frank Robert. 1986. Mood and Modality. Cambridge: Cambridge University Press. 
PARMENTIER, Richard J. 1993. "The Political Function of Reported Speech: A Belauan Example", Reflexive Language. Reported Speech and Metapragmatics, J. A. Lucy (ed.). Cambridge: Cambridge University Press.

PARTEE, Barbara Hall. 1973. "The Syntax and Semantics of Quotation", en A Festschrift for Morris Halle, S. R. Anderson y P. Kiparsky (eds). San Francisco: Holt, Reinhart and Winston: 410-418.

PAVÓN LuCERO, María Victoria. 1999. "Clases de partículas: preposición, conjunción y adverbio", en Gramática descriptiva de la lengua española, vol. 1: Sintaxis básica de las clases de palabras. I. Bosque y V. Demonte (eds.). Madrid: Espasa Calpe-Real Academia EspañolaFundación José Ortega y Gasset (Nebrija y Bello): 565-655.

PÊCHEUX, Michel. (1975) 1982. Language Semantics and Ideology. Trad. Harbans Nagpal. London: Macmillan.

PEndones, Covadonga. 1992. "La heterogeneidad enunciativa: algunas manifestaciones de la heterogeneidad mostrada", Estudios de Lingüística, 8: 9-24.

Perelman, Chaïm y Lucie Olbrects-Tyteca. (1970) 1989. Tratado de la argumentación. Trad. Julia Sevilla Muñoz. Madrid: Gredos (Biblioteca Románica Hispánica, III: Manuales, 69).

Perfetti, Charles A., et al 1987. "Comprehending Newspaper Headlines", Journal of Memory and Language, 26 (6): 692-713.

PerlmutTer, David M. y Paul Postal. 1977. "Towards a Universal Characterization of Passivization", en Proceedings Third Annual Meeting of the Berkeley Linguistics Society. Berkeley: University of California: 394-417.

PERret, Michèle. 1994. L'Énonciation en grammaire du texte. Paris: Éditions Nathan.

PERRIDON, Harry. 1996. "Reported Speech in Swedish", en Reported Speech, T. A. J. M. Janssen y W. van der Wurff (eds.). AmsterdamPhiladelphia: John Benjamins: 165-188.

PEYTARD, Jean. 1975. "Lecture(s) d'une «aire scripturale »: la page de journal", Langue Française, 28 : 39-59.

Platón. La república. Trad. Antonio Gómez Robledo, 2. a ed. México: Universidad Nacional Autónoma de México, 2000 (Biblioteca Scriptorum Graecorum et Romanorum Mexicana).

Polo, José. 1974. Ortografía y ciencia del lenguaje. Madrid: Paraninfo.

Porto Dapena, José Álvaro. 1989. Tiempos y formas no personales del verbo. Madrid: Taurus.

Pottier NAvarro, Huguette. 1990. "La prensa y la evolución de la lengua", Lingüística Española Actual, 12 (2): 243-256.

Pou AmÉrigo, María José. 2004. "Los titulares periodísticos", en Redacción para periodistas: informar e interpretar, J. Cantavela y J. F. Serrano (eds.). Barcelona: Ariel (Ariel Comunicación): 239-257.

Prensa Latina. 1989. Normas de redacción. La Habana: Prensa Latina. 
PUIG, Luisa. 1991. Discurso y argumentación: un análisis semántico y pragmático. México: Universidad Nacional Autónoma de México (Cuadernos del Seminario de Poética, 15).

. 2000. La realidad ausente. Teoría y análisis polifónicos de la argumentación. México: Universidad Nacional Autónoma de México (Bitácora de Retórica, 12).

. 2004. "Polifonía lingüística y polifonía narrativa", Acta Poética, 25 (2): 377-417.

. 2005. "El éthos en la perspectiva pragmática", en Homenaje a Rubén Bonifaz Nuño, A. Vigueras (ed.). México: Universidad Nacional Autónoma de México (Ediciones Especiales, 35): 323-339.

. 2010. "El éthos del discurso", en Espacios de la retórica. Problemas filosóficos y literarios, H. Beristáin y G. Ramírez Vidal (eds.). México: Universidad Nacional Autónoma de México (Bitácora de Retórica, 27): 149-165.

QuAGliA, María Luisa. 2001. "Modalidad epistémica: tipología y esquema modélico de análisis", en Semántica. Oración y enunciación, J. García Fajardo (ed.). México: El Colegio de México (Estudios de Lingüística, 1): 59-47.

RAE y AALE $C f$. Real Academia Española y Asociación de Academias de la Lengua Española.

RAE. $C f$. Real Academia Española.

ReAl ACADEMia Española. (1931) 1962. Gramática de la lengua española. Madrid: Espasa Calpe.

—. 1973. Esbozo de una nueva gramática de la lengua española. Madrid: Espasa Calpe.

2001. Diccionario de la lengua española. 22. ${ }^{\text {a }}$ ed. Madrid: Espasa Calpe.

ReAl ACADEmia Española y Asociación de Academias de la Lengua Española. 2005. Diccionario panhispánico de dudas. Bogotá: Santillana.

. 2009. Nueva gramática de la lengua española, vols. I y II. Madrid: Espasa Libros.

- 2010a. Nueva gramática de la lengua española. Manual. México: Editorial Planeta Mexicana.

- 2010b. Ortografía de la lengua española. Madrid: Espasa Libros.

Rebollo Torío, Miguel Á. 2008. "Análisis de titulares en la prensa hispana", Anuario de Estudios Filológicos, 31: 163-175.

RÉCANATI, François. 2000. Oratio Obliqua, Oratio Recta: An Essay on Metarepresentation. Cambridge, Mass.: MIT Press-Bradford Books.

RÉCANATi, François. 2001. “Open Quotation”, Mind, 439: 637-687.

Reforma. 2004. Manual de estilo. México: Grupo Reforma.

REISZ DE RIVAROLA, Susana. 1988. "Hablar, repetir, citar. Las voces del discurso literario (y del discurso crítico)", Lexis, 12 (2): 139-178.

REYES, Graciela. 1982. "El estilo indirecto en el texto periodístico", Lingüística Española Actual, 4 (1): 1-21. 
REYes, Graciela. 1984. Polifonía textual: la citación en el relato literario. Madrid: Gredos (Biblioteca Románica Hispánica, II: Estudios y Ensayos, 340).

. 1993. Los procedimientos de cita: estilo directo y estilo indirecto. Madrid, Arco Libros (Cuadernos de Lengua Española, J).

—. 1994a. "La cita en español: gramática y pragmática", Gramática del español, V. Demonte (ed.). México: El Colegio de México (Publicaciones de la Nueva Revista de Filología Hispánica, 6): 591627.

. 1994b. Los procedimientos de cita: citas encubiertas y ecos. Madrid: Arco Libros (Cuadernos de Lengua Española, O).

RICHARDSON, John E. 2007. Analysing newspapers: an approach from critical discourse analysis. New York: Palgrave Macmillan.

RiIHo, Timo. 1979. Por y para. Estudio sobre los orígenes y la evolución de una oposición prepositiva iberorrománica. Helsingfors [Helsinki]: Societas Scientiarum Fennica (Commentationes Humanarum Litterarum, 62).

RiVADENEIRA PRADA, Raúl. 2007. Periodismo: la teoría general de los sistemas y la ciencia de la comunicación. 5. ${ }^{\mathrm{a}}$ ed. México: Trillas.

RIVAROLA, José Luis y Susana Reisz de Rivarola. 1984. "Semiótica del discurso referido", en Homenaje a Ana María Barrenechea, L. Schwartz Lerner e I. Lerner (eds.). Madrid: Castalia: 151-174.

RocA PONS, José. 1974. Introducción a la gramática. 3. ${ }^{a}$ ed. Barcelona: Teide.

Rodrigo Alsina, Miquel. 1989. La construcción de la noticia. 4. ${ }^{a}$ ed. Barcelona: Paidós (Paidós Comunicación, 34).

Rojas Espinos A, María de Jesús. 2003. Manual para redactar titulares. México: Trillas.

RoJO, Guillermo. 1974. "La temporalidad verbal en español”, Verba, 1: 68149.

1976. "La correlación temporal”, Verba, 3: 65-89.

Rojo, Guillermo y Alexandre Veiga. 1999. "El tiempo verbal. Los tiempos simples", en Gramática descriptiva de la lengua española, vol. 2: Las construcciones sintácticas fundamentales, Relaciones temporales, aspectuales y modales, I. Bosque y V. Demonte (eds.). Madrid: Espasa Calpe-Real Academia Española-Fundación José Ortega y Gasset (Nebrija y Bello): 2867-2934.

Romero Álvarez, María de Lourdes. 1990. Análisis sintáctico de los titulares en diez periódicos nacionales. Méxco: Universidad Nacional Autónoma de México (tesis).

. 1996. "El relato periodístico como acto de habla", Revista Mexicana de Ciencias Políticas y Sociales, 169: 9-27.

. 2000. "El relato de palabras como recurso de credibilidad en el relato periodístico", en Ensayos semióticos. Dominios, modelos y miradas desde el cruce de la naturaleza y la cultura, A. Gimate Welsh (ed.). 
México: BUAP-Porrúa-Asociación Mexicana de Estudios Semióticos: 97-106.

. 2006. La realidad construida en el periodismo. Reflexiones teóricas. México: Universidad Nacional Autónoma de México-Miguel Ángel Porrúa.

- 2009. "El punto de vista en los relatos periodísticos. Propuesta metodológica de análisis", en Espejismos mediáticos. Ensayos sobre la construcción de la realidad periodística, M. de L. Romero Álvarez (ed.). México: Universidad Nacional Autónoma de México-SITESA: 13-38.

Romero Gualda, María Victoria. 1991. "Rasgos morfosintácticos de la prensa americana", en El español de América. Actas del III Congreso Internacional de El Español de América, vol. I, C. Hernández, G. de Granda, C. Hoyos et al. (eds.) Salamanca: Junta de Castilla y León: 541-549.

. 1994. El español en los medios de comunicación. 2." ed. Madrid: Arco Libros.

ROSIER, Laurence. 1999. Le discours rapporté: Histoire, théories, pratiques. Paris: Duculot.

—. 2002. "La presse et les modalités du discours rapporté : l'effet d'hyperréalisme du discours direct surmarqué", Information Grammaticale, 94: 27-32.

RUBio FERnÁnDEZ, Lisardo. 1976. "Estructura del estilo indirecto en latín y en castellano. Problemas de traducción", en Introducción a la sintaxis estructural del latín, vol. 2. Barcelona: Ariel (Convivium, 4): 65-78.

Ruiz Acosta, María José. 1992. "Los titulares en prensa: estudio de su evolución y lenguaje", en Lenguaje informativo y filmográfico, A. Antona et al. Sevilla: Universidad de Sevilla (Pliegos de Información, 1).

SAKITA, Tomoko I. 2002. Reporting Discourse, Tense, and Cognition. Oxford: Elsevier.

SÁNCHEZ-REY, Alfonso. 1991. El lenguaje literario de la «nueva novela» hispánica. Madrid: Editorial MAPFRE.

S Antiago, Ramón. 1998. "Ortografía, libros de estilo y prensa diaria: $E l$ País, El Mundo y Abc", Español Actual, 70: 7-35.

Santos Río, Luis. 2003. Diccionario de partículas. Salamanca: LusoEspañola de Ediciones.

SCHAEFFER, Jean-Marie. (1995) 1998. "Tiempo, modo y voz en el relato", en Nuevo diccionario enciclopédico de las ciencias del lenguaje, O. Ducrot y J. M. Shaeffer (eds.). Trad. María Camino Girón, Teresa María Rodríguez y Marta Tordesillas. Madrid: Arrecife: 651-666.

SCHIfFRIN, Deborah. 1994. Approaches to Discourse. Cambridge, MA: Blackwell.

SCHUELKE, Gertrude L. 1958. "Slipping' in Indirect Discourse”, American Speech, 33: 90-98. 
SEARLE, John Rogers. 1976. "The Classification of Illocutionary Acts", Language in Society, 5 (1): 1-24.

SeCAnella, Petra María. 1980. El lid, fórmula inicial de la noticia. Barcelona: A.T.E.

SECO, Manuel. 1977. "El léxico de hoy", en Comunicación y lenguaje. R. Lapesa (ed.). Madrid: Karpós: 183-201.

- 1996. Gramática esencial del español. 4. ${ }^{\mathrm{a}}$ ed. Madrid: Espasa Calpe.

Seco, Manuel, Olimpia Andrés Puente y Gabino Ramos González. 1999. Diccionario del español actual, vols. I y II. Madrid: Aguilar.

SECO, Rafael. 1954. Manual de gramática española. Madrid: Aguilar.

SHORT, Michael H. 1988. "Speech Presentation, the Novel and the Press", en The Taming of the Text: Explorations in Language, Literature and Culture, W. van Peer, (ed.). London-New York: Routledge: 61-81.

SIGAL, Leon V. (1973) 1979. Reporteros y funcionarios. La organización y las normas de la elaboración de noticias. Trad. María Elisa Moreno Canalejas. México: Gernika.

Silva-CorVAlÁN, Carmen. 2001. Sociolingüística y pragmática del español. Washington: Georgetown University Press.

SIP. $C f$. Sociedad Interamericana de Prensa.

SlEMBROUCK, Stef. 1986. "Towards a Description of Speech Presentation and Speech Reportage in Newspaper Language", Studia germanica gandensia, 9: 44-115.

SlembrouCK, Stef. 1992. "The Parliamentary Hansard 'Verbatim' Report: The Written Construction of Spoken Discourse", Language and Literature, 1 (2): 101-119.

Sociedad InteramericAnA DE Prensa. 1965. Manual de estilo. César García-Pons (redactor). Nueva York: Hobbs, Dorman \& Company.

SPITZER, Leo. 1948. "Sur le discours direct lié (DDL)", Boulletin Linquistique, 14: 19-77.

Stainton, Robert. 1999. "Remarks on the Syntax and Semantics of Mixed Quotation”, en Philosophy and Linguistics, K. Murasugi y R. Stainton (eds.). Boulder: Westview Press: 259-278.

STEEL, Brian. 1971. "Los estilos funcionales y la enseñanza del idioma", Español Actual, 18: 9-18.

SternberG, Meir. 1982. "Proteus in Quotation-land: Mimesis and the Forms of Reported Discourse", Poetics Today, 3 (2): 107-156.

-. 1991. "How indirect speech meens. Syntax, semantics, poetics, pragmatics", en Literary Pragmatics, R. Sell (ed.). London: Routledge.

STRAUCH, Gérard. 1974. "De quelques interprétations récentes du style indirect libre", Recherches Anglaises et Américaines, 7: 40-73.

- 1984. "De la litteralité du discours rapporté", Recherches Anglaises et Américaines, 17: 159-181.

TACCA, Óscar. 1978. Las voces de la novela. 2. a ed. Madrid: Gredos (Biblioteca Románica Hispánica, II: Estudios y Ensayos, 194). 
TAnnen, Deborah. 1989. Talking Voices: Repetition, Dialogue and Imagery in Conversational Discourse. Cambridge: Cambridge University Press.

Tejada Conde-Pelayo, Leonor. 2005. Manual idiomático del periodista. México: Editorial Alfil.

The Associated Press. 2002. Stylebook and Briefing on Media Law with Internet Guide and Glossary. 37. ${ }^{\mathrm{a}}$ ed. N. Goldstein (ed.). New York: The Associated Press.

. 2003. Guide to Punctuation. R. J. Cappon (redactor). New York: Basic Books.

Thogmartin, Clyde. 1991. "The Pragmatics of French Newspaper Headlines", en Levels of Linguistic Adaptation, J. Verschueren (ed.). Amsterdam-Philadelphia: John Benjamins (Pragmatics \& Beyond, New Series, 6:2): 249-266.

Thompson, Geoff. 1996. "Voices in the Text: Discourse Perspectives on Language Reports", Applied Linguistics, 17: 501-530.

TILBY, Robert. 1977. "Notes sur l'emploi du discours discontinu dans les titres de presse", Ibérica, 1:313-322.

Todorov, Tzvetan. (1968) 1975. ¿Qué es el estructuralismo? Poética. Trad. Ricardo Pochtar. Buenos Aires: Losada (Biblioteca Clásica y Contemporánea).

. (1972) 2000. "Estilo", en Diccionario enciclopédico de las ciencias del lenguaje, O. Ducrot y T. Todorov (eds.). Trad. Enrique Pezzoni, 21. a ed. México: Siglo XXI (Lingüística).

Toolan, Michael J. 1988. Narrative: A Critical Linguistic Introduction. London: Routledge.

TsohatzIDIS, Savas L. 1998. "The Hybrid Theory of Mixed Quotation", Mind, 427: 661-664.

URRUTIA CÁRdEnAS, Hernán. 1981. “Apelación y procedimientos léxicos en titulares periodísticos del ámbito político", Revista Española de Lingüística, 11 (2): 403-417.

VAN DER HOUWEN, Fleur. 2000. "El habla directa vs. indirecta y la organización del discurso", Foro Hispánico, 17: 27-40.

Van DiJK, Teun Adrianus. (1977) 1980. Texto y contexto. Semántica y pragmática del discurso. Madrid: Cátedra.

. (1978) 1998. Estructuras y funciones del discurso. Una introducción interdisciplinaria a la lingüística del texto y a los estudios del discurso. Trad. Myra Gann y Martí Mur, 12. ${ }^{a}$ ed. México: Siglo XXI. . (1980) 1990. La noticia como discurso. Trad. Guillermo Gal. Barcelona: Paidós (Paidós Comunicación, 41).

_. 1983. "Estructuras textuales de las noticias de la prensa", Anàlisi, 78: 77-105.

- 1985. "Introduction: Levels and Dimensions of Discourse Analysis", en Handbook of Discourse Analysis, vol. 2: Dimensions of Discourse, T. A. van Dijk (ed.). London: Academic Press: 1-11.

. (1988a) 1997. “CCómo se lleva una minoría a los titulares? Minorías étnicas en la prensa", en Racismo y análisis crítico de los medios. Trad. 
Montserrat Basté Kraan. Barcelona: Paidós (Paidós Comunicación, 82): $125-173$.

. 1988b. News Analysis: Case Studies of International and National News in the Press. Hillsdale: Earlbaum.

-. 1991. "The Interdisciplinary Study of News as Discourse", en Handbook of Qualitative Methods in Mass Communication Research, K. Bruhn-Jensen y N. Jankowski (eds.). London: Routledge: 108-120.

- 2003. Ideología y discurso. Barcelona: Ariel (Ariel Lingüística). - 2006. "Discurso y manipulación: discusión teórica y algunas aplicaciones". Trad. Marianne Peronard. Signos, 60: 49-74.

VANDELANOTTE, Lieven. 2004. "Deixis and grounding in speech and thought representation", Journal of Pragmatics, 36-3: 489-520.

VASIlACHIS DE GiAldino, Irene. 1998. La construcción de las representaciones sociales. Discurso político y prensa escrita. Un análisis sociológico, jurídico y lingüístico. Barcelona: Gedisa (Hombre y Sociedad, CLA·DE·MA).

VERDÍN DÍAZ, Guillermo. 1970 Introducción al estilo indirecto libre en español. Madrid: CSIC (Revista de Filología Española, anejo XCI).

VERÓN, Eliseo. 1984. "Ideología y comunicación de masas. La sistematización de la violencia política", en Lenguaje y comunicación social, E. Verón (ed.). Buenos Aires: Nueva Visión: 133-191.

VERSCHUEREN, Jef. 1985. International News Reporting: Metapragmatic Metaphors and the U-2. Amsterdam: John Benjamins.

Vicente MAteu, Juan Antonio. 1994. La deíxis: egocentrismo y subjetividad en el lenguaje. Murcia: Universidad de Murcia.

—. 2007. "Discurso reproducido e interpretación de la fuerza ilocutiva en la prensa escrita”, Revista de Investigación Lingüística, 10: 225242.

Vigil VÁzQueZ, Manuel. 1966. "Arte de titular y confección”, en Enciclopedia del periodismo, N. González Ruiz (dir.). 4. ${ }^{a}$ ed. Madrid: Noguer: 199-314.

VinCENT, Diane y Laurent Perrin. 1999. "On the narrative vs non-narrative functions of reported speech: A socio-pragmatic study", Journal of Sociolinguistics, 3 (3): 291-313.

Voloshinov, Valentin Nikólaievich. (1929) 1992. El marxismo y la filosofía del lenguaje. Trad. Tatiana Bubnova. Madrid: Alianza (Alianza Universidad, 740).

W ALES, Katie. 1989. A Dictionary of Stylistics. London: Longman.

WAUGH, Linda R. 1995. "Reported Speech in Journalistic Discourse: The relation of Function and Text". Text, 15 (1): 129-173.

WiERzBICKA, Anna. 1974. "The Semantics of Direct and Indirect Discourse", Papers in Linguistics, 7 (3-4): 267-307.

Zorrilla BARroso, José Manuel. 1996. El titular de la noticia. Estudio de los titulares informativos en los diarios de difusión nacional. Madrid: Universidad Complutense de Madrid (tesis). 
ZubizArReta, María Luisa. 1999. "Funciones informativas: tema y foco", en Gramática descriptiva de la lengua española, vol. 3: Entre la oración y el discurso, Morfología, I. Bosque y V. Demonte (eds.). Madrid: Espasa Calpe-Real Academia Española-Fundación José Ortega y Gasset (Nebrija y Bello): 4215-4242.

ZWICKY, Arnold M. 1971. "In a Manner of Speaking", Linguistic Inquiry, 2: 223-233.

\section{Fuentes informáticas}

Real ACAdemia Española. Corpus diacrónico del español (CORDE) [en línea]. <http://www.rae.es> [consultado el 18/11/2010]. 


\section{APÉNDICE 1: IDENTIFICACIÓN DE DECLARANTES}

\begin{tabular}{|l|l|}
\hline \multicolumn{1}{|c|}{ NOMBRE DEL DECLARANTE } & INFORMACIÓN IDENTIFICADORA \\
\hline Acosta, Rafael & Futbolista venezolano \\
\hline Alfaro, Jorge Mario & Beisbolista colombiano \\
\hline Amaro Jr., Rubén & $\begin{array}{l}\text { Gerente general de los Filis de } \\
\text { Filadelfia (equipo de béisbol) }\end{array}$ \\
\hline Andrade Sánchez, Sergio Gustavo & Exproductor artístico mexicano, preso \\
\hline Arias, Rodrigo & $\begin{array}{l}\text { Ministro de la Presidencia de Costa } \\
\text { Rica }\end{array}$ \\
\hline Auth, José & Diputado chileno \\
\hline Bayly, Jaime & Escritor peruano \\
\hline Beltrones, Manlio Fabio & Senador mexicano \\
\hline Benedicto XVI & Papa \\
\hline Besson, Luc & Cineasta francés \\
\hline Bours, Eduardo & $\begin{array}{l}\text { Gobernador del Estado mexicano de } \\
\text { Sonora }\end{array}$ \\
\hline Brito, Luís Miguel & Futbolista portugués \\
\hline Brown, Gordon & Primer ministro británico \\
\hline Calderón Hinojosa, Felipe & Presidente de México \\
\hline Carlin, John & Periodista británico \\
\hline Carrió, Elisa & $\begin{array}{l}\text { Política argentina, fundadora y } \\
\text { presidenta del partido Coalición } \\
\text { Cívica para la Afirmación de una } \\
\text { República Igualitaria }\end{array}$ \\
\hline Presidente de Venezuela \\
\hline Chávez, Hugo & Ministro de Trabajo de España \\
\hline Corbacho, Celestino & Secretario de Salud de México \\
\hline Córdova Villalobos, José Ángel & Senador mexicano \\
\hline Creel, Santiago & $\begin{array}{l}\text { Delegada (figura similar a la de un } \\
\text { alcalde) en la demarcación Miguel } \\
\text { Hidalgo del Distrito Federal mexicano }\end{array}$ \\
\hline Cuevas, Gabriela & Diputado argentino \\
\hline De Narváez, Francisco & Futbolista mexicano \\
\hline Del Olmo, Joaquín & Tenista serbio \\
\hline Djokovic, Novak & Político estadounidense \\
\hline Edwards, John & Excandidato a la Presidencia de Chile \\
\hline Enríquez-Ominami, Marco & Pintor mexicano \\
\hline Falcón, Héctor & $\begin{array}{l}\text { Deportista estadounidense, mariscal } \\
\text { de campo (quarterback) de los } \\
\text { Vikingos de Minnesota. }\end{array}$ \\
\hline Favre, Brett & \\
\hline
\end{tabular}




\begin{tabular}{|c|c|}
\hline Fernández de Cevallos, Diego & Exsenador mexicano \\
\hline Fernández de Kirchner, Cristina & Presidenta de Argentina \\
\hline Fernández, Aníbal & Jefe de Gabinete de Argentina \\
\hline Gerrard, Steven & Futbolista británico \\
\hline González Torres, Víctor & $\begin{array}{l}\text { Empresario mexicano, aspirante a la } \\
\text { Presidencia de México }\end{array}$ \\
\hline Greene, Ashley & Actriz estadounidense \\
\hline Guardiola, Joseph & $\begin{array}{l}\text { Entrenador del equipo de fútbol } \\
\text { Barcelona }\end{array}$ \\
\hline Gubaidulina, Sofía & Compositora tártara \\
\hline Hicks, Tom & $\begin{array}{l}\text { Propietario del equipo de béisbol de } \\
\text { los Vigilantes de Texas }\end{array}$ \\
\hline Hudson, Kate & Actriz estadounidense \\
\hline Isabel II & Reina de Inglaterra \\
\hline Jean, Wyclef & Cantante haitiano \\
\hline Jiménez Peña, Radhamés & $\begin{array}{l}\text { Procurador General de la República } \\
\text { Dominicana }\end{array}$ \\
\hline Jolie, Angelina & Actriz estadounidense \\
\hline Lagos, Ricardo & Expresidente de Chile \\
\hline Larraín, Guillermo & $\begin{array}{l}\text { Superintendente de Valores y Seguros } \\
\text { de Chile }\end{array}$ \\
\hline Lohan, Lindsay & Actriz estadounidense \\
\hline López Obrador, Andrés Manuel & $\begin{array}{l}\text { Político mexicano, excandidato a la } \\
\text { Presidencia de México }\end{array}$ \\
\hline Lugo, Fernando & Presidente de Paraguay \\
\hline Lula da Silva, Luiz Inácio & Presidente de Brasil \\
\hline Maradona, Diego Armando & Futbolista argentino \\
\hline Marcos, Niurka & Bailarina cubana \\
\hline Martín, Ricky & Cantante puertorriqueño \\
\hline Matos Berrido, Leonardo & $\begin{array}{l}\text { Presidente de la Liga de Béisbol } \\
\text { Profesional de la República } \\
\text { Dominicana }\end{array}$ \\
\hline Matsui, Hideki & Beisbolista japonés \\
\hline Maza, Enrique & $\begin{array}{l}\text { Sacerdote y periodista mexicano- } \\
\text { estadounidense }\end{array}$ \\
\hline Mendoza, Waldo & Economista peruano \\
\hline Micheletti, Roberto & Presidente de Honduras \\
\hline Morales, Evo & Presidente de Bolivia \\
\hline Moratinos, Miguel Ángel & $\begin{array}{l}\text { Ministro de Asuntos Exteriores de } \\
\text { España }\end{array}$ \\
\hline Napolitano, Janet & $\begin{array}{l}\text { Secretaria de Seguridad Nacional de } \\
\text { Estados Unidos }\end{array}$ \\
\hline Obama, Barack & Presidente de Estados Unidos \\
\hline Ortega, Jesús & $\begin{array}{l}\text { Político mexicano, líder del Partido de } \\
\text { la Revolución Democrática }\end{array}$ \\
\hline
\end{tabular}




\begin{tabular}{|c|c|}
\hline Patrón Laviada, Patricio José & $\begin{array}{l}\text { Exgobernador del Estado mexicano de } \\
\text { Yucatán }\end{array}$ \\
\hline Pelé & Futbolista brasileño \\
\hline Pelusso, Gerardo & $\begin{array}{l}\text { Entrenador del equipo de fútbol de la } \\
\text { Universidad de Chile }\end{array}$ \\
\hline Pérez de Cuellar, Javier & $\begin{array}{l}\text { Exsecretario general de la } \\
\text { Organización de las Naciones Unidas }\end{array}$ \\
\hline Pérez, Pared & Senador dominicano \\
\hline Piñera, Sebastián & Presidente electo de Chile \\
\hline Pitt, Brad & Actor estadounidense \\
\hline Preval, René & Presidente de Haití \\
\hline Rajoy, Mariano & $\begin{array}{l}\text { Político español, líder del Partido } \\
\text { Popular }\end{array}$ \\
\hline Ramírez Acuña, Francisco & $\begin{array}{l}\text { Exgobernador del Estado mexicano de } \\
\text { Jalisco }\end{array}$ \\
\hline Ramírez Corzo, Luis & $\begin{array}{l}\text { Exdirector general de Petróleos } \\
\text { Mexicanos }\end{array}$ \\
\hline Rivera Carrera, Norberto & Cardenal mexicano \\
\hline Rivera, Victoria & $\begin{array}{l}\text { Exnovia del cantante español } \\
\text { Alejandro Sanz }\end{array}$ \\
\hline Rodríguez Zapatero, José Luis & Presidente del Gobierno de España \\
\hline Ruiz, Samuel & Obispo mexicano \\
\hline Sahagún, Marta & $\begin{array}{l}\text { Mujer del expresidente de México } \\
\text { Vicente Fox }\end{array}$ \\
\hline Salinas Pliego, Ricardo & Empresario mexicano \\
\hline Samper, Ernesto & Expresidente de Colombia \\
\hline Sánchez, Mark & $\begin{array}{l}\text { Deportista estadounidense, mariscal } \\
\text { de campo (quarterback) de los Jets de } \\
\text { Nueva York }\end{array}$ \\
\hline Scafati, Luis & Dibujante argentino \\
\hline Schumacher, Michael & Piloto alemán \\
\hline Seigner, Emmanuelle & Mujer del cineasta Roman Polanski \\
\hline Simon Munaro, Yehude & $\begin{array}{l}\text { Expresidente del Consejo de Ministros } \\
\text { de Perú }\end{array}$ \\
\hline Solanas, Fernando & Diputado argentino \\
\hline Subero Isa, Jorge & $\begin{array}{l}\text { Presidente de la Suprema Corte de } \\
\text { Justicia de República Dominicana }\end{array}$ \\
\hline Tévez, Carlos & Futbolista argentino \\
\hline Travolta, John & Actor estadounidense \\
\hline Uribe, Álvaro & Presidente de Colombia \\
\hline Valcárcel, Ramón Luis & Presidente de Murcia \\
\hline Venegas, Julieta & Cantante mexicana \\
\hline Zelaya, Manuel & Expresidente de Honduras, depuesto \\
\hline
\end{tabular}




\section{APÉNDICE 2: SIgNificados dE ABREVIATURAS EMPLEADAS EN LOS TITULARES CITADOS}

\begin{tabular}{|c|c|}
\hline ABREVIATURA & SIGNIFICADO \\
\hline AMA & Agencia Mundial Antidopaje \\
\hline AmCham & $\begin{array}{l}\text { American Chamber of Commerce } \\
\text { ('Cámara Estadounidense de } \\
\text { Comercio', Estados Unidos) }\end{array}$ \\
\hline AMLO & $\begin{array}{l}\text { Andrés Manuel López Obrador } \\
\text { (México) }\end{array}$ \\
\hline ANV & Acción Nacionalista Vasca (España) \\
\hline Asobancaria & Asociación Bancaria (Colombia) \\
\hline AyA & $\begin{array}{l}\text { Acueductos y Alcantarillados (Costa } \\
\text { Rica) }\end{array}$ \\
\hline Banamex & Banco Nacional de México (México) \\
\hline BCRA & $\begin{array}{l}\text { Banco Central de la República } \\
\text { Argentina (Argentina) }\end{array}$ \\
\hline Cecut & Centro Cultural Tijuana (México) \\
\hline CIA & $\begin{array}{l}\text { Central Intelligence Agency } \\
\text { ('Agencia Central de Espionaje', } \\
\text { Estados Unidos) }\end{array}$ \\
\hline Conago & $\begin{array}{l}\text { Conferencia Nacional de } \\
\text { Gobernadores (México) }\end{array}$ \\
\hline $\mathrm{DC}$ & $\begin{array}{l}\text { Democracia Cristiana (Partido } \\
\text { Demócrata Cristiano, Chile) }\end{array}$ \\
\hline $\mathrm{DF}$ & Distrito Federal (México) \\
\hline EA & $\begin{array}{l}\text { Eusko Alkartasuna ('Solidaridad } \\
\text { Vasca', España) }\end{array}$ \\
\hline Eln & $\begin{array}{l}\text { Ejército de Liberación Nacional } \\
\text { (Colombia) }\end{array}$ \\
\hline ESO & $\begin{array}{l}\text { Educación Secundaria Obligatoria } \\
\text { (España) }\end{array}$ \\
\hline ETA & $\begin{array}{l}\text { Euskadi Ta Askatasuna ('País Vasco } \\
\text { y Libertad', España) }\end{array}$ \\
\hline EU, EE UU, EE.UU. & Estados Unidos \\
\hline FARC, Farc & $\begin{array}{l}\text { Fuerzas Armadas Revolucionaras de } \\
\text { Colombia (Colombia) }\end{array}$ \\
\hline FBI & $\begin{array}{l}\text { Federal Bureau of Investigation } \\
\text { ('Oficina Federal de Investigaciones', } \\
\text { Estados Unidos) }\end{array}$ \\
\hline $\mathrm{FCH}$ & Felipe Calderón Hinojosa (México) \\
\hline
\end{tabular}




\begin{tabular}{|c|c|}
\hline Femexfut & Federación Mexicana de Fútbol \\
\hline FNE & Fiscalía Nacional Económica (Chile) \\
\hline GB & Gran Bretaña \\
\hline Inali & $\begin{array}{l}\text { Instituto Nacional de Lenguas } \\
\text { Indígenas (México) }\end{array}$ \\
\hline Incofer & $\begin{array}{l}\text { Instituto Costarricense de } \\
\text { Ferrocarriles (Costa Rica) }\end{array}$ \\
\hline INDEC & $\begin{array}{l}\text { Instituto Nacional de Estadística y } \\
\text { Censos (Argentina) }\end{array}$ \\
\hline IP & Iniciativa Privada \\
\hline LA & Los Ángeles (Estados Unidos) \\
\hline mdd & Millones de dólares \\
\hline OMS & Organización Mundial de la Salud \\
\hline ONU & Organización de las Naciones Unidas \\
\hline Orcao & $\begin{array}{l}\text { Organización de Cafeticultores de } \\
\text { Ocosingo (México) }\end{array}$ \\
\hline PAN & Partido Acción Nacional (México) \\
\hline $\mathrm{PD}$ & Partido por la Democracia (Chile) \\
\hline Pemex & Petróleos Mexicanos (México) \\
\hline PGJEM & $\begin{array}{l}\text { Procuraduría General de Justicia del } \\
\text { Estado de México (México) }\end{array}$ \\
\hline PMA & Programa Mundial de Alimentos \\
\hline PNV & Partido Nacionalista Vasco (España) \\
\hline PP & Partido Popular (España) \\
\hline PRD & $\begin{array}{l}\text { Partido de la Revolución Democrática } \\
\text { (México) }\end{array}$ \\
\hline PRI & $\begin{array}{l}\text { Partido Revolucionario Institucional } \\
\text { (México) }\end{array}$ \\
\hline Procomer & $\begin{array}{l}\text { Promotora del Comercio Exterior } \\
\text { (Costa Rica) }\end{array}$ \\
\hline PSE & $\begin{array}{l}\text { Partido Socialista de Euskadi } \\
\text { (España) }\end{array}$ \\
\hline PSOE & $\begin{array}{l}\text { Partido Socialista Obrero Español } \\
\text { (España) }\end{array}$ \\
\hline $\mathrm{PT}$ & Partido del Trabajo (México) \\
\hline SEC & $\begin{array}{l}\text { Securities and Exchange Commission } \\
\text { ('Comisión del Mercado de Valores', } \\
\text { Estados Unidos) }\end{array}$ \\
\hline Segob & Secretaría de Gobernación (México) \\
\hline SEP & $\begin{array}{l}\text { Secretaría de Educación Pública } \\
\text { (México) }\end{array}$ \\
\hline SLP & San Luis Potosí (México) \\
\hline STPS & $\begin{array}{l}\text { Secretaría del Trabajo y Previsión } \\
\text { Social (México) }\end{array}$ \\
\hline TLC & Tratado de Libre Comercio (México) \\
\hline
\end{tabular}




\begin{tabular}{|l|l|}
\hline UASD & $\begin{array}{l}\text { Universidad Autónoma de Santo } \\
\text { Domingo (República Dominicana) }\end{array}$ \\
\hline UCLA & $\begin{array}{l}\text { University of California, Los Angeles } \\
\text { ('Universidad de California, sede Los } \\
\text { Ángeles', Estados Unidos) }\end{array}$ \\
\hline UCR & $\begin{array}{l}\text { Universidad de Costa Rica (Costa } \\
\text { Rica) }\end{array}$ \\
\hline UE & Unión Europea \\
\hline UNICEF, Unicef & $\begin{array}{l}\text { United Nations International } \\
\text { Children's Emergency Found ('Fondo } \\
\text { Internacional de las Naciones Unidas } \\
\text { de Socorro a la Infancia') }\end{array}$ \\
\hline VFQ & Vicente Fox Quesada (México) \\
\hline VTR & Vía Trans Radio Chilena, S.A. (Chile) \\
\hline
\end{tabular}




\section{Abreviaturas empleadas \\ EN LAS REFERENCIAS}

\section{Corpus cuantificado}

$\begin{array}{lll}\text { Abreviatura } & \text { Significado } & \text { Lugar de publicación } \\ \text { CLA } & \text { Clarín } & \text { Buenos Aires, Argentina } \\ \text { COM } & \text { El Comercio } & \text { Lima, Perú } \\ \text { ELN } & \text { El Nacional } & \text { Caracas, Venezuela } \\ \text { ELP } & \text { El País } & \text { Madrid, España } \\ \text { HOY } & \text { Hoy } & \text { Santo Domingo, República Dominicana } \\ \text { LAN } & \text { La Nación } & \text { San José, Costa Rica } \\ \text { MER } & \text { El Mercurio } & \text { Santiago, Chile } \\ \text { OPI } & \text { La Opinión } & \text { Los Ángeles, Estados Unidos } \\ \text { TPO } & \text { El Tiempo } & \text { Bogotá, Colombia } \\ \text { UNI } & \text { El Universal } & \text { México, México }\end{array}$

Corpus piloto

$\begin{array}{lll}\text { Abreviatura } & \text { Significado } & \text { Lugar de publicación } \\ & & \\ \text { ABC } & \text { Abc } & \text { Madrid, España } \\ \text { EXC } & \text { Excélsior } & \text { México, México } \\ \text { GMA } & \text { Granma } & \text { La Habana, Cuba } \\ \text { JOR } & \text { La Jornada } & \text { México, México } \\ \text { LAP } & \text { La Prensa } & \text { México, México } \\ \text { MIL } & \text { Milenio Diario } & \text { México, México } \\ \text { MUN } & \text { El Mundo } & \text { Madrid, España } \\ \text { PUB } & \text { Público } & \text { Madrid, España } \\ \text { REF } & \text { Reforma } & \text { México, México } \\ \text { SOL } & \text { El Sol de México } & \text { México, México } \\ \text { YUC } & \text { Diario de Yucatán } & \text { Mérida, México }\end{array}$

